\section{La construcción de la subjetividad en la narrativa de Severo Sarduy}

\section{Tesis presentada para la obtención del grado de Doctora en Letras}

\section{Director: José Amícola. Codirectora: Graciela Salto.}

Este documento está disponible para su consulta y descarga en Memoria Académica, el repositorio institucional de la Facultad de Humanidades y Ciencias de la Educación de la Universidad Nacional de La Plata, que procura la reunión, el registro, la difusión y la preservación de la producción científico-académica édita e inédita de los miembros de su comunidad académica. Para más información, visite el sitio

\section{www.memoria.fahce.unlp.edu.ar}

Esta iniciativa está a cargo de BIBHUMA, la Biblioteca de la Facultad, que lleva adelante las tareas de gestión y coordinación para la concreción de los objetivos planteados. Para más información, visite el sitio www.bibhuma.fahce.unlp.edu.ar

\section{Cita sugerida}

Bertón, S. A. (2010) La construcción de la subjetividad en la narrativa de Severo Sarduy [en línea]. Tesis doctoral. Universidad Nacional de La Plata. Facultad de Humanidades y Ciencias de la Educación. Disponible en: http://www.fuentesmemoria.fahce.unlp. edu.ar/tesis/te.358/te.358.pdf

\section{Licenciamiento}

Esta obra está bajo una licencia Atribución-No comercial-Sin obras derivadas 2.5 Argentina de Creative Commons.

Para ver una copia breve de esta licencia, visite http://creativecommons.org/licenses/by-nc-nd/2.5/ar/.

Para ver la licencia completa en código legal, visite http://creativecommons.org/licenses/by-nc-nd/2.5/ar/legalcode. 
UNIVERSIDAD NACIONAL DE LA PLATA

FACULTAD DE HUMANIDADES Y CIENCIAS DE LA EDUCACIÓN SECRETARIA DE POSGRADO

Doctorado en Letras

\section{LA CONSTRUCCIÓN DE LA SUBJETIVIDAD EN}

\section{LA NARRATIVA DE SEVERO SARDUY}

Tesis Doctoral

Doctoranda: Profa. Sonia Bertón

Director: Dr. José Amícola

Co-directora: Dra. Graciela Salto 
Agradecimientos

Muchas personas fueron importantes en la realización de este trabajo. Algunas acompañaron el proceso desde la responsabilidad de guiar la investigación, corregirla, enseñarme y sostenerme en los momentos menos felices. José Amícola y Graciela Salto tuvieron esta tarea y para ellos van mis primeros agradecimientos. José Maristany, por su parte, tuvo un papel preponderante en mi formación como así también en aquellas acciones que de alguna manera me allanaron el camino de inicio al Doctorado.

Otras personas me acompañaron con aliento, buena predisposición y afecto: mi familia, mis amigos, mis compañeros de trabajo, Quique, Hugo.

Pero otras personas fueron indispensables. Sin ellas nunca hubiera podido llegar a feliz término o tal vez nunca hubiera empezado. A mi padre, a mi madre y a Selene les dedico mis páginas. 


\title{
La construcción de la subjetividad en la
}

\author{
narrativa de Severo Sarduy
}

Introducción

5

I. Subjetividad y lenguaje después de los sesenta

I. 1. La escritura es el arte de recrear la realidad: Cuba como lugar de producción de discursos y subjetividad 10

I. 2. La escritura es el arte de la elipsis: Severo Sarduy, un exiliado de sí mismo.

31

I. 3. La escritura es el arte de descomponer un orden y componer un desorden: Francia, Tel Quel y el discurso sobre el sujeto....40

\section{Escrituras de la subjetividad}

II. 1. Gestos de un viaje sin retorno .72

II. $\quad 1.1$. El viaje ........................................77

II. 2. Mamá yo quiero saber... De donde son los cantantes: la elusión de una respuesta. 89

II. 2. 1. La desterritorialización.................................91

II. 3. El exilio: neobarroco de la revolución.....................107

II. 3. 1. Cobra: escritura y fetichización.......................128

II. 4. Para que nadie sepa que tengo miedo. Cocuyo: búsqueda y recuperación de un mundo inexistente. 


\section{Escrituras del cuerpo}

III. 1. Cuerpo, sexo y género: devenires de una subjetividad.....157

III. 2. Cuerpo abyectado: la escritura del exilio en Maitreya........171

III. 3. De los devenires a la política: implicancias de las subjetividades homoeróticas..........................................189

III. 4. Colibrí: simulación e intersticios.........................199

III. 4. 1. La simulación........................................ 199

III. 4. 2. El intersticio.......................................207

III. 5. Literatura y sida: paradojas de una muerte anunciada ..... 216

IV. 6. Si las palabras toman cuerpo...Pájaros de la playa: escritura y subjetividad .........................................227

V. Conclusiones .............................. 247

VI. Bibliografía ........................................252 


\section{Introducción}

Un gesto fundacional de la producción artística en general y de la literaria en particular es la construcción de la propia imagen que los escritores llevan a cabo dentro de sus propios textos en los que condensan figuras, proyecciones y contrafiguras de sí mismos. Juegan, en esta construcción, problemáticas de las más variadas índoles que constituyen campos en tensión prestos a emerger en la superficie textual. Se trata de aspectos personales, relaciones del campo intelectual y político, cuestiones históricas, sociales y corporales, genealogías, herencias, polémicas y debates, discursos y contradiscursos.

Teniendo en cuenta esta premisa, analizaré la obra de Severo Sarduy a partir de la hipótesis de que cuerpo y escritura son dos formaciones discursivas que constituyen ejes problemáticos de importancia relevante en la narrativa ficcional ya que en relación con ellas construye su imagen de escritor y artista. Ésta se cimenta sobre diversos discursos estéticos y artísticos que confluyen en su obra de una manera particular y promisoria dando como resultado una escritura que descuella en singularidades sin perder el anclaje socio-histórico sobre el que se sustenta. Así, neobarroco, psicoanálisis, postestructuralismo, Tel Quel son algunas de las claves que conforman este universo escriturario. Cuba, Francia, exilio, cuerpo, género, homoerotismo, sida son otras. Entre ellas, Sarduy teje una trama a partir de la cual se posiciona como intelectual cultural disidente con el modelo hegemónico que impone el campo intelectual cubano postrevolucionario por lo que, la otra gran palabra, la palabra aludida pero elidida, la que nunca se nombra en sus trabajos pero permanece como un centro ocultado/develado 
es política, en su sentido más amplio, en el sentido de quien la asume no como un compromiso discursivo sino como una práctica de trabajo, de escritura, de vida.

Por todo esto, la obra de Sarduy se erige en uno de esos raros ejemplos a los que nadie duda en reconocer sus virtudes pero, precisamente por las particularidades con que ellas se dan, tampoco se instituye en norma académica o de mercado. Tal vez sea éste uno de los mayores reconocimientos que pueda recibir su trabajo y su pensamiento.

Elegí el corpus atendiendo a una categoría de género algo esquemática y establecida a priori que me permitiera fijar ciertos parámetros funcionales para el abordaje. Me concentré, entonces, en aquellos textos que, en una primera instancia, se encuadran dentro de lo considerado como narrativa ficcional en tanto funcionan como una posible puerta de entrada a la escritura sarduyana, de algún modo representativa de las consignas que constituyen las principales de su pensamiento. Sin embargo, de ninguna manera la considero concluyente. Uno de los objetivos que me propuse, en este sentido, fue demostrar que en el trabajo de Sarduy no sólo existen vínculos estrechos entre los distintos tipos de textos, de manera que es difícil sustraerse a la tentación de leer unos bajo la óptica de los otros - tal como lo ha hecho, con pocas excepciones, la crítica anterior-, sino también que los límites genéricos en esta obra son difusos y escurridizos y uno de los modos principales mediante los cuales Sarduy plantea su propuesta de escritura.

Organizaré mi escritura en tres largos capítulos —con sus respectivos apartados a fin aclarar la lectura- que corresponden a los tres 
ejes fundamentales que se desprenden de mi hipótesis inicial. Esto es la escritura, el cuerpo y el campo cultural, todos en función del objetivo común que fue analizar cómo Sarduy hace operar estas problemáticas en función de la construcción de su subjetividad disidente.

En el primer capítulo, "Subjetividad y lenguaje después de los sesenta", trabajaré aquellas problemáticas que, considero, jugaron un papel fundamental como contexto de producción de la escritura de Sarduy. Cuba, Tel Quel y la propia biografía del escritor marcan las líneas principales sobre las que habrá de desarrollarse el trabajo posterior en tanto si la primera señala el lugar desde el que parte, física, psíquica, lingüística y literariamente, y al que regresa obsesivamente desde su escritura, el grupo Tel Quel constituye, en primer lugar, el sustento teórico, pero también, una alternativa política que opone a la Revolución - la de pretensiones absolutas, la que impone el realismo socialista como modo estético por excelencia, la que instaura el "parametraje" para los homosexuales- la revolución: así, con minúsculas, sin pretensiones de totalidad ni de totalitarismo, la del lenguaje, la del sujeto, la del cuerpo.

En el segundo capítulo, "Escrituras de la subjetividad", analizaré cuatro novelas —Gestos (1963), De donde son los cantantes (1967), Cobra (1972) y Cocuyo (1990) - con la pretensión de ahondar en ciertas problemáticas relacionadas con la noción de sujeto desde un eje que profundiza particularmente en las estrategias escriturarias empleadas. Abordaré entonces, conceptos y discusiones sobre "géneros textuales", "barroco/ neobarroco", sus rupturas y características, y las vinculaciones 
que se establecen con las nociones de Lacan y Kristeva sobre la subjetividad, los debates en torno de la identidad latinoamericana y las teorías lingüísticas que reflexionan sobre problemáticas como la desestructuración del autor, las voces enunciativas, las diferencias entre textos de placer/ textos de goce, los excesos, desplazamientos y diseminaciones —-Barthes y Derrida.

Sólo a los efectos de la organización del trabajo no plantearé con profundidad la cuestión del cuerpo en el capítulo II. No es que desconozca su presencia y su importancia en las novelas mencionadas sino que preferí dedicarle un capítulo —el III- y un corpus -Maitreya (1978), Colibrí (1984) y Pájaros de la playa (1993)_para desarrollarlo con profusión. Es así que, poco a poco, el cuerpo y las problemáticas en que está inserto — género sexual, homoerotismo, enfermedad, sida- se van sumando y cobran relevancia de tema central en "Escrituras del cuerpo". Nuevos conceptos, nuevas herramientas de análisis y, en mi opinión, la radicalización, de alguna manera metonímica, de una noción: la de inestabilidad, inquietud, perturbación que desde el "viaje" propuesto en Gestos devino en "desterritorialización”, "exilio", “abyección” y así hasta terminar en el "mal" de Pájaros, inquietud extrema, ineludible, desgarradora, que obliga a Sarduy a advertirnos "Enlaces y desenlaces que tornaré a contaros. Si la Pelona, siempre presta a golpear, me concede una tregua" (1999 [1993]: 999).

Una obra, un trabajo, un autor ocupa determinado lugar en el campo intelectual no tanto por lo que es sino especialmente por qué y por cuánto ha 
suscitado. El caso de Sarduy siempre me ha parecido por lo menos "extraño" en tanto no se duda en reconocer sus méritos pero sí son relativamente pocos los trabajos críticos que se ocupan de sus textos. En este sentido, procuro hacer una contribución que no pretende desconocer ni destruir otros aportes sino sumar en función de un trabajo escriturario que tiene relevancia fundamental en el ámbito cultural latinoamericano. 


\title{
I. Subjetividad y lenguaje después de los
}

\author{
sesenta
}

\section{I.1. La escritura es el arte de recrear la realidad: Cuba como lugar de producción de discursos y subjetividad}

\begin{abstract}
Así, pareceríamos poder afirmar que al finalizar el siglo XX en América Latina constituimos culturas que, escindidas por una parte $\mathrm{y}$ tensionadas por imposiciones externas por otra, van transformando su desgarramiento en vibración estética, consolidando en belleza su irresolución, experimentando de este modo con dolor el parto de sí mismas.
\end{abstract}

Ana Pizarro, El sur y los trópicos

La historia de Cuba no constituye una excepción, en términos de opresión y violencia, a la historia general de los demás países de América Latina. Por el contrario, en parte por su estratégica ubicación geográfica, en parte por su particular conformación económica y socio-cultural, es, en este sentido, uno de los ejemplos más flagrantes, aunque especialmente marcado por algunos sucesos que acentúan y singularizan esta historia de dominación.

El 28 de octubre de 1492 marca, con exactitud, la entrada de Cuba en el relato histórico de la cultura occidental a través del Diario del primer viaje de Cristóbal Colón. Sin embargo, esta precisión de nombres y fechas, lejos de indicar los inicios de una entidad libre, da curso a una vasta red de acontecimientos sellada por las pugnas en pos de la construcción de una existencia en libertad y autodeterminación, de conocimiento mutuo y 
reconocimiento externo, que tiene como peculiaridades fundamentales la esclavitud, las luchas por la independencia y la Revolución de $1959^{1}$. La contracara de estos procesos la constituye la relación de dominación y violencia a la que ya hice alusión y que tuvo como protagonistas principales a España, Estados Unidos y la connivencia indispensable de algunos grupos de elite locales que apoyaron y sostuvieron, en distintos períodos y de variadas maneras, estas políticas opresoras que sustituyeron una dominación colonial española de cuatrocientos años por la primacía del país del norte desde 1898 en adelante.

El $1^{\circ}$ de enero de 1959 señala una nueva entrada de Cuba en la historia de la cultura occidental —y, diría más, de gran parte del mundo contemporáneo - aunque, a diferencia de la primera, ésta parece ser una resolución tomada por el pueblo cubano con el afán de recuperar su autonomía política nacional perdida, entre otras razones, en manos del dictador Fulgencio Batista desde el año 1952. La Revolución Cubana, que se había gestado y alimentado con sucesos como el asalto al Cuartel Moncada (1954) y la participación activa de movimientos de izquierda, estudiantiles, de obreros y campesinos —entre los cuales adquiriría especial relevancia el "26 de julio", nombre que alude a la fecha del asalto al Moncada - tenía su llegada triunfal a La Habana encabezada por unos de sus líderes máximos, Fidel Castro, quien paulatinamente iría cobrando poder y relevancia singulares en la nueva organización gubernamental del país al punto de instaurar lo que en adelante se dio a conocer como "el gobierno

\footnotetext{
${ }^{1} \mathrm{Si}$ bien es cierto que cada uno de estos procesos no constituye un elemento exclusivo y excluyente de este país, sí lo son en la forma en que se dieron y la relación que se estableció entre ellos. A cuenta de que la bibliografía abunda, no profundizaré en este aspecto.
} 
castrista" ${ }^{2}$. Pero principalmente, sería esta revolución el suceso histórico que pondría a Cuba en particular, y a América Latina en general, a tono con los acontecimientos de cambio y transformaciones vertiginosos característicos de las décadas del sesenta y del setenta ${ }^{3}$. En el mismo proceso, se constituyó ella misma en uno de los hitos definitorios de esta época en tanto implicó la relocalización del país y el continente en el mundo, el afianzamiento de sus relaciones $\mathrm{y}$, en el caso específicamente cubano, la redefinición $\mathrm{y}$ consecuente exaltación de lo que se consideró la identidad nacional —la cubanidad-.

Inserta en una tradición histórica según la cual la nación en Cuba fue articulada ideológicamente por los escritores que, desde el siglo XVII, reinterpretaron la geografía, la historia, la identidad social y la cultura, la Revolución Cubana tomó la figura de José Martí como uno de sus

\footnotetext{
${ }^{2}$ Según Tulio Halperin Donghi fueron los juicios a los criminales de guerra y la expulsión del presidente Urrutia los acontecimientos que mostraron que "el gobierno revolucionario tenía una estructura caudillesca que causó inesperada indignación entre muchos de los que habían solido mostrarse más comprensivos frente a las peculiaridades políticas latinoamericanas" (1986: 403).

${ }^{3}$ Claudia Gilman utiliza el concepto de "época" para referirse al bloque que constituyen las décadas sesenta y setenta en relación con la problemática de los intelectuales latinoamericanos reunidos en torno a la Revolución Cubana. En tanto admite la necesidad de problematizar los recortes y límites necesarios al relato histórico, Gilman asume esta noción como un instrumento que participa de los rasgos de una cesura —que, precisamente, no se condice con exactitud temporal con las décadas que designa sino que se extiende desde fines de los años cincuenta hasta mediados de los setenta - a la vez que instaura las condiciones necesarias para que aparezca un objeto de discurso (2003:36). En este sentido, son la Revolución Cubana, la descolonización africana, la guerra de Vietnam, la rebelión antirracista en los Estados Unidos y los diversos brotes de rebeldía juvenil algunas de las relaciones institucionales, políticas, económicas y sociales sin las cuales no se podría pensar en el surgimiento de la percepción de que el mundo estaba cambiando vertiginosamente (37). De modo que, si el comienzo de la época está marcado por lo que se entendió como la crisis de la hegemonía del sistema capitalista, su fin se vislumbra a partir de la recomposición "del viejo modo de dominación hegemónica, que dio por tierra con las expectativas revolucionarias que habían caracterizado su inicio" (56). Sin embargo, aun cuando la noción implique cierta idea de homogeneidad temporal, es necesario aclarar, según Gilman, que no se puede "descartar, dentro de la coherencia interna que esa denominación sugiere virajes, contrastes y momentos de ruptura, que, aun encontrando su lugar dentro de la formación discursiva dominante, marcan periodizaciones internas que es necesario revelar" (39). Ver en este mismo sentido, Jameson, Fredric. Periodizar los 60. (1997). Córdoba: Alción Editora.
} 
principales baluartes ya que en ella se condensaban tres elementos considerados fundamentales en el proceso de reconstitución nacional iniciado (Leclercq 316; Bernabé 64-68; Ponte 26-31) ${ }^{4}$. Así, el poeta, el intelectual y el soldado que por diversos procesos históricos habían llegado a constituir tres roles perfectamente diferenciados $y$, en términos generales, atribuibles a diferentes sujetos, fueron adquiriendo, poco a poco y conforme el gobierno revolucionario se afincaba en el poder, características unificadoras por las cuales pronto formaron parte de una fórmula de igualdad mediante la cual un término fue impensable separado de los otros.

En este sentido, es posible afirmar que uno de los fenómenos propios de la época fue la constitución de un campo intelectual latinoamericano que, reunido en torno a la Revolución Cubana —a la que tuvo como un punto clave de pertenencias constituyendo La Habana la capital real y simbólica que los aglutinaba - y gracias al surgimiento incipiente de un mercado editorial, se sintió partícipe activo de un proceso de transformación en el que la política y la cultura del continente se hallaban en estado inaugural (Gilman 2003: 30) ${ }^{5}$. A comienzo de los años sesenta, los artistas y letrados de América Latina ocuparon el espacio público para dirigirse a la sociedad bajo la convicción de que, como intelectuales, podían y debían convertirse

\footnotetext{
${ }^{4}$ Las relaciones entre la Revolución y los revolucionarios y Martí son constantes, entre otros, en la obra de Roberto Fernández Retamar. Así, por ejemplo, en "Calibán" afirma: "nosotros debemos decir, en cambio, que el verdadero hogar de Martí era el futuro, y por lo pronto este tiempo nuestro que sencillamente no se entiende sin un conocimiento cabal de su obra" (1998: 32). Y más adelante: "Martí es, como luego Fidel" (36).

${ }^{5}$ Susana Zanetti propone el concepto religación —en contraposición con el de campo intelectual — como una herramienta de investigación útil para abordar el problema de la unidad de la literatura latinoamericana en tanto entiende que "encara el estudio de los vínculos efectivos concretados de muy diversos modos a lo largo de nuestra historia literaria entre autores y obras, entre éstos y los lectores y críticos, entre los diversos centros de América Latina y entre sus instituciones formales e informales más allá de las fronteras nacionales" (1994: 6).
} 
en agentes de su transformación radical por lo que asumieron nuevas, y no

tan nuevas, tareas -entre las principales, la de construir la

latinoamericanidad, y en sentido más particular, la cubanidad - que fueron

variando en sus caracteres de acuerdo a cómo se modificaban las

condiciones políticas y relacionales con respecto al gobierno

revolucionario ${ }^{6}$.

${ }^{6}$ La complejidad del problema implicó buscar la respuesta en una gran variedad de alternativas, algunas, incluso, discordantes entre sí, que se han desplazado desde posturas sustentadas sobre categorías genéticas desprovistas de todo tipo de anclaje en la realidad social, económica, histórica o cultural a otras, más pendientes del rol de las estructuras de poder en el campo cultural.

Para el primero de los casos, corresponde mencionar, en primer lugar, la categoría de mestizaje desarrollada, en 1925, por el mexicano José Vasconcelos en el ensayo "La raza cósmica" y ampliamente retomada en trabajos posteriores. En el prólogo que Vasconcelos incorpora a su versión bonaerense de 1948, parte de explicitar la tesis central del libro según la cual "las distintas razas del mundo tienden a mezclarse cada vez más, hasta formar un nuevo tipo humano, compuesto con la selección de cada uno de los pueblos existentes"(1). De este modo, pone de manifiesto una idea que circuló de manera generalizada hacia la segunda década del siglo XX y que significó el reconocimiento del mestizaje como un proceso deseable en la formación de las identidades nacionales de numerosos países latinoamericanos en tanto se consideró la máxima expresión de un proceso que sintetizaría las virtudes del africano, el indígena y el europeo (Luis Duno Gottberg 2003: 23) y que - no es un dato menor- debería forjarse en el territorio del "Nuevo Mundo" como en ningún otro lugar. Visto de esta manera, el mestizaje constituye una categoría que se reviste con un manto de pretendida "ingenuidad" pero que, tal como lo afirma Duno Gottberg y por esta misma característica, es necesario entenderlo como "una práctica del poder que construye cierta idea de la identidad nacional a partir de la disolución de las diferencias étnicas" (25) en tanto el discurso de inclusión o exclusión que genera responde a la imposibilidad de los sectores hegemónicos para pensar los lazos sociales basados en la diferencia (26).

Por su parte, Ángel Rama retoma en su trabajo Transculturación narrativa en América Latina (1982) para la literatura y la crítica literarias la categoría de "transculturación" proveniente de la antropología y definida por Fernando Ortiz en su obra Contrapunteo cubano del tabaco y del azúcar (1940) como las diferentes fases del proceso transitivo de una cultura a otra. Dicho proceso no consiste solamente en adquirir una cultura sino que implica también "la pérdida o desarraigo de una cultura precedente, lo que pudiera decirse una parcial desculturación, y, además, significa la consiguiente creación de nuevos fenómenos culturales que pudieran denominarse neoculturación” (1987: 96). Según Rama, esta definición revela cierta resistencia a considerar la cultura propia como una entidad pasiva o inferior, desprovista de toda respuesta creadora. Por el contrario, el concepto implica una doble valoración: por un lado, que la cultura de la comunidad latinoamericana está compuesta de valores idiosincrásicos que pueden reconocerse actuando desde fechas remotas; por el otro, confirma la energía creadora que la mueve y que pone de manifiesto, en virtud, precisamente, de esa capacidad para crear con originalidad, que pertenece a una sociedad viva (40-1). Sin embargo, Rama no deja de hacer algunas advertencias en relación con el término utilizado por Ortiz, principalmente cuando se trata de aplicarlo a la literatura. En este sentido, afirma que el diseño "geométrico" orticiano que consiste en tres momentos - una parcial deculturación, primero; las incorporaciones de culturas externas en segundo lugar y, finalmente, la reacomodación entre los elementos foráneos y los propiosno da cuenta suficientemente de los criterios de selectividad e invención que deben ser necesariamente postulados dado que son los que certifican la creatividad de la comunidad 
En estos primeros momentos del período, el campo intelectual latinoamericano se caracterizó por entablar relaciones personales que ligaron no sólo a escritores sino también a críticos, y tuvieron fuerzas suficientes como para establecer modalidades de crítica profesional y un sistema de alianzas, convergencias, consagraciones y, por consiguiente, exclusiones determinantes en la configuración de dicho campo (Gilman 104). De este modo, fue adoptando, poco a poco, la silueta de una familia de intelectuales hermanados en algunas causas comunes: la existencia de América Latina como unidad más allá de la diversidad, la Revolución Cubana como acontecimiento central de los tiempos y a partir de estos, la necesidad de articular un discurso coherente y homogéneo que pudiera rotularse como literatura nacional y que recuperara ciertos valores épicos como el héroe — geográfica e históricamente situado, masculino, íntegro—generador de un discurso monolítico, capaz de responder las preguntas acerca de la identidad — la cubanidad, la latinoamericanidad.

A partir de estos presupuestos, los integrantes de la comunidad intelectual de América Latina establecieron pautas de política cultural que impusieron rígidas formas de leer y escribir que, si bien en un primer momento fueron elementos de convergencia, pronto se convirtieron en preceptos excluyentes (Ponte; Díaz; Basile). Desde mediados de la década del sesenta en adelante, la figura del intelectual, que hasta el momento se relacionaba con el compromiso — acogiendo a Jean-Paul Sartre como a una

(45). Visto de esta manera, el concepto de transculturación implica un juego de tensiones y conflictos en los que el poder es un factor determinante por lo que constituye, en contraposición con la perspectiva "armónica" del mestizaje, una apuesta comprometida que intenta dar una nueva respuesta a la problemática de la identidad latinoamericana. 
de sus figuras "faro" y a Julien Brenda como sostén ideológico—, comenzó a sufrir un desplazamiento desde su lugar como conciencia crítica de la sociedad al de intelectual revolucionario. Esto tuvo como consecuencia el establecimiento de ciertos cánones artísticos relacionados con tendencias realistas y un proceso de cuestionamientos, vigilancias mutuas y autovigilancias que terminó con la imposición de la dicotomía intelectual versus revolucionario ${ }^{7}$.

Dicho de otra manera, con el paso del tiempo y el afianzamiento del gobierno de Castro, la noción de revolución pasaría a ocupar plenamente el ámbito de lo político por lo que la pertenencia a la izquierda se convirtió en un elemento fundamental de legitimidad de la práctica intelectual. En la Reunión de la Organización Latinoamericana de Solidaridad, realizada entre el 31 de julio y el 10 de agosto de 1967 y presidida por Haydée Santamaría, se concluyó en dos puntos centrales: primero, que la lucha armada era la única vía de la revolución y, segundo que Cuba debía ser considerada la vanguardia de la revolución latinoamericana (117). Esto sentó las bases definitivas para una nueva definición del intelectual revolucionario que, de aquí en más, pondría el énfasis en conformar una dicotomía entre intelectual y hombre de acción; es decir, daría lugar a un nuevo objeto discursivo, el intelectual como problema, que derivó en un profundo antiintelectualismo según el cual los letrados comenzaron a preguntarse con vehemencia $-\mathrm{y}$ culpa - acerca de su función social. Sólo podían reclamar la figura de

\footnotetext{
${ }^{7}$ El mismo Sartre que había postulado la noción de "literatura comprometida" fue quien, después de Mayo del '68 reformuló sus dichos declarando públicamente que había estado equivocado durante largo tiempo en tanto el compromiso era un acto y no una palabra. De esa manera, el concepto dejó de funcionar como "paraguas" abarcativo de las nociones de crítico, ideólogo, escritor y militante y comenzó a demarcar de modo tajante la separación entre intelectuales y hombres de acción (Gilman 169-170).
} 
intelectual revolucionario, entonces, quienes pasaron directamente a la militancia política o quienes formaban parte del antiintelectualismo y atacaban los defectos burgueses de los intelectuales (163). Este discurso se instituyó en una poderosa herramienta de exclusión a través de la cual se estigmatizó como burgueses, contrarrevolucionarios o mercantilistas a todos quienes postularon la especificidad de su tarea y reclamaron la libertad de creación.

En este sentido, tal como lo afirma Ambrosio Fornet, fue la revista Casa de las Américas, uno de los voceros culturales más prestigiosos del período, la que asumió la responsabilidad de reproducir las estrategias político-culturales no sólo de la institución a la que pertenece y representa sino a la Revolución en general ya que se proyectó en un ámbito abarcativo de toda la cultura latinoamericana y caribeña y promovió "una concepción de la cultura centrada en la búsqueda de nuestra propia identidad" (1999: 424) ${ }^{8}$. Según Juan Carlos Quintero Herencia, la revista, que es uno de los textos centrales del corpus de su trabajo, forma parte del entramado

\footnotetext{
${ }^{8}$ El primer número de la revista Casa de las Américas fue publicado en 1960 con la dirección de Haydeé Santamaría y la subdirección de Alberto Robaina. Contó como sus primeros responsables a Fausto Masó y Antón Arrufat y entre quienes colaboraron en el primer número se encuentran Ezequiel Martínez Estrada, el propio Antón Arrufat, Virgilio Piñera, Miguel Ángel Asturias, Luis Enrique Valencia y Carlos Fuentes. Una característica importante de la revista es que con el paso del tiempo y su afianzamiento fue sumando colaboradores de toda Latinoamérica. Otra característica directamente relacionada con esta es que se estableció un sistema de préstamos entre las publicaciones que permitió que estos colaboradores y sus textos afianzaran sus vínculos personales, artísticos e ideológicos a partir del núcleo generador en que se convirtió Casa de las Américas como vocera de Cuba y la Revolución.

A partir del $\mathrm{N}^{\circ} 30$ asumió la dirección Roberto Fernández Retamar y quedó desvinculado Antón Arrufat. Esta situación generó múltiples controversias al punto de que, según lo relata Claudia Gilman, Guillermo Cabrera Infante se refirió a Fernández Retamar como "un "poetastro envidioso", que deseoso de alzarse con el cargo, recordó a las autoridades que su predecesor era homosexual, entre otras cuestiones" (2003: 82). Si bien es difícil tener certezas sobre lo realmente sucedido en estas circunstancias, sí es cierto que la historia entre Arrufat y el gobierno revolucionario no tendrá un final feliz ya que el conflicto estallará en 1968 cuando la UNEAC le niegue el premio al escritor obtenido por su obra Los siete contra Tebas (ver cap. II).
} 
discursivo que hizo posible una imagen del acontecer revolucionario cubano (2002: 18) ${ }^{9}$. En tanto constituye una "zona de posibilidades poéticas y políticas" Casa de las Américas permite analizar las textualidades que lidian con el problema de la voz del intelectual por lo que se puede advertir cómo durante el proceso de radicalización de la Revolución cumplió con la función que el Estado le asignara conformando un corpus textual producto de una labor de refundición y de "en-raizamiento" de metáforas y figuras fundacionales del discurso latinoamericanista. En este sentido, la revista realiza una operación mediante la cual nombra el espacio de la identidad desde la autosuficiencia que implica el situarse en "la propia casa" y, de este modo, "ontologiza la identidad americana a través de la naturalización del lugar donde se verificaría la "unidad latinoamericana"” (79) instituyéndose, ella misma, en un espacio conformado para albergar un continente en plural (86).

\footnotetext{
${ }^{9}$ Un referente anterior inmediato a Casa de las Américas es el suplemento literario Lunes de Revolución (1959-1961), aparecida el 23 de marzo de 1959 entre las páginas del órgano del Movimiento Revolucionario "26 de Julio". Guillermo Cabrera Infante, Pablo Armando Fernández y Raúl Martínez fueron, respectivamente, director, subdirector y director artístico del suplemento.

Una de las vinculaciones entre Casa y Lunes estuvo dada por la presencia en ambos grupos de escritores como Antón Arrufat y Fausto Masó. Otra, más importante, creo, que la anterior, es que ambos textos comparten un gesto inaugural que pone el énfasis en fomentar la apertura a múltiples poéticas como una manera de reencuentro con el ser nacional y literario. Por otro lado, las dos publicaciones ponen empeño en demostrar que han sido propiciadas por el fenómeno revolucionario y se muestran en consonancia con la Revolución para la cual constituían un espacio en el que las políticas culturales podían cumplir con el objetivo de cerrar distancias entre las instituciones y la vida civil cubana. En tal sentido, y arrogándose el derecho que le confería el sentirse "nuevas voces" críticas de un orden viejo", algunos intelectuales, entre los que pueden contarse Heberto Padilla, Cabrera Infante o el mismo Sarduy dedicaron desde las páginas de Lunes comentarios críticos a Orígenes que apuntaban a remarcar la incongruencia temporal entre la poética origenista y las demandas revolucionarias del presente (Quintero Herencia 320-6). La visita de figuras de la talla de Jean Paul Sartre dio a estos intelectuales y artistas cubanos una relevancia singular que los puso en el centro de un escenario internacional preocupado por vincular la lucha y las letras en una relación que, veremos, poco a poco se fue transformando cada vez más en un enfrentamiento desigual. Lunes constituyó, en este sentido, más que un órgano cultural, un espacio de confluencia entre el arte y la política que permitió a los intelectuales jóvenes manifestar sus inquietudes revolucionarias en dimensiones que trascendieron las fronteras cubanas.
} 
Por otra parte, Nadia Lie analiza y explica, aplicando el modelo actancial de Greimas como modo de calificar las relaciones entre los sujetos estrechamente vinculados con la vida cultural del país, cómo los miembros de la revista modificaron su discurso adoptando una postura cada vez más dogmática (1996). Si bien desde un primer momento los revolucionarios fueron identificados con la figura del héroe y los contrarrevolucionarios con la del antihéroe, el intelectual gozó durante este período de cierta libertad de expresión ya que, no estar comprometido con la Revolución no significó, necesariamente, estar en su contra. Pero este esquema varió y se tornó cada vez más codificado e inflexible en tanto el gobierno revolucionario fue institucionalizándose. El intelectual fue incorporado en términos excluyentes: ser revolucionario asumiendo un compromiso activo con la Revolución o ser un antihéroe al servicio del imperialismo norteamericano. Es el momento, entonces, de los "casos" — como el de la revista Nuevo Mundo o el de Herberto Padilla— que por no ajustarse a la homogeneidad pretendida provocaron una reacción virulenta por parte del círculo hegemónico de intelectuales poniendo sobre el tapete las discrepancias que con bastante esfuerzo procuraban acallar ${ }^{10}$.

\footnotetext{
${ }^{10}$ En el año 1966, la aparición de la revista Mundo Nuevo implicó una de las primeras disrupciones en el campo intelectual latinoamericano ya que, dirigida por Emir Rodríguez Monegal - a quien Roberto Fernández Retamar calificó, en su ensayo Calibán, como "servidor del imperialismo"-, debió resistir los ataques de una enemistad de vieja data que mantenía con Ángel Rama quien se encargó de señalar las relaciones entre Mundo Nuevo y Cuadernos y su posible financiamiento por parte de fundaciones norteamericanas vinculadas a la CIA. Estos hechos, aunque nunca demostrados fehacientemente, produjeron una controversia que tuvo como consecuencia una primera división entre los miembros del campo intelectual.

Ya en 1971, el renombrado "Caso Padilla" sería el síntoma del recrudecimiento de los tiempos. Acusado de estar involucrado en actividades contrarrevolucionarias, Heberto Padilla fue detenido y obligado a declarar públicamente sus supuestos, en tanto tampoco fueron comprobados fehacientemente, errores -y los de sus amigos, a algunos de los cuales invitó a que lo imitaran- en la UNEAC. Este acto - culminación de un proceso que había comenzado con el premio al poemario Fuera del juego ganado en el concurso que organizaba la UNEAC y luego negado por la misma institución - fue interpretado de
} 
Como es de esperar, el cambio político que trajo aparejadas las transformaciones en la configuración del campo intelectual, también tuvo fuertes repercusiones en lo que respecta a lo específicamente estético. Si bien en un primer momento los artistas latinoamericanos, y en forma especial los cubanos, defendieron la modernización cultural y el contacto con las culturas internacionales también se mostraron sensiblemente contrarios a adoptar el arte oficial soviético que propugnaba el realismo socialista como la forma artística por excelencia (66). Llegados a este punto de la historia política e intelectual de la Revolución se hace necesario advertir que el panorama ha cambiado significativamente en tanto el antiintelectualismo dio lugar a posturas rígidas cuyas valoraciones estaban muy lejos de fundamentarse en criterios artísticos. Así, por ejemplo, Ambrosio Fornet afirmaría, varios años más tarde:

El realismo socialista - la literatura como pedagogía y hagiografía, orientada metodológicamente hacia la creación de "héroes positivos" y la estratégica ausencia de conflictos antagónicos

distintas maneras. Para algunos, fue un sincero arrepentimiento el que llevó a Padilla a querer recomponer sus relaciones con la Revolución. Para otros, como Juan Goytisolo, fue un esperpéntico montaje teatral, "grotesco reflejo caribeño de las célebres purgas de Moscú" (1986: 184) del que "cuantos participaron en él, ya fuera en calidad de jueces, reos o simples testigos, salieron inevitablemente manchados y las salpicaduras alcanzaron asimismo a quienes, tras leer la transcripción de la agencia oficial castrista, nos veíamos obligados a reaccionar" (185). Una de estas reacciones se dio, precisamente, a través de la revista Libre de la que Goytisolo fue uno de sus fundadores. Si bien el proyecto de Libre se estaba gestando desde mediados de 1970, se vio demorada la aparición del primer número debido al estallido del caso Padilla ya que los integrantes del grupo sintieron la obligación de hacerse partícipes en el debate suscitado. Esta intervención, que implicó, entre otros, dos textos claves como fueron la "Carta de los intelectuales a Fidel Castro" y la "Carta abierta de los 62”, y la vinculación directa que se estableció entre ésta y Mundo Nuevo debido al origen reprochable -al menos para algunos miembros del campo intelectual latinoamericano - de los fondos de financiamiento hicieron de la revista Libre una crónica de una muerte anunciada en tanto se podría decir que su desaparición se fue gestando al ritmo de los únicos cuatro números publicados.

Las elecciones teóricas y críticas de Libre —estrechamente relacionadas con Tel Quelfueron otro punto de crítica en tanto se las consideró como "falsas pretensiones revolucionarias de un cuerpo teórico idealista y fetichizado" (Gilman 299).

Sarduy fue uno de los primeros convocados por Goytisolo para conformar el proyecto Libre y, aunque mantuvo una participación exenta de protagonismo, esto — sumado al hecho de haber publicado en Mundo Nuevo - fue un elemento más para agregar su nombre a la lista de los "traidores" a la Revolución. 
en el "seno del pueblo"- producía en nosotros, mis amigos pequeñoburgueses y yo, la misma reacción de quien se encuentra una mosca en el vaso de leche. [...] El realismo socialista no era "intrínsecamente perverso"; lo intrínsecamente perverso fue la imposición de esa fórmula en la URSS, donde lo que pudo haber sido una escuela, una corriente literaria y artística más, se convirtió de pronto en doctrina oficial, de obligatorio cumplimiento (2007: 5-6).

Del debate acerca de cómo hacer literatura revolucionaria se pasó, entonces, a la orden, la instrucción que, sustentada en la supremacía otorgada a Cuba —y más específicamente al cuadro dirigente cubanocomo vanguardia del movimiento antiimperialista latinoamericano, tuvo el poder no sólo de indicar sino de autorizar o rechazar, en nombre de una posición revolucionaria, las propuestas políticas o culturales que se realizaban. La literatura y la cultura se convirtieron en un lujo al que se debía renunciar en tanto la revolución trascendía lo artístico y, para hacerla, sólo requería de "revolucionarios". Escribir, pintar, producir obras de arte en general se transformó en una actividad desvinculada del concepto estético y puesta al servicio de la política, como reflejo directo de la ideología —dominante. En este contexto, una de las prácticas más cuestionadas fue la crítica literaria — principalmente del estructuralismo y el postestructuralismo francés que pusieron el énfasis en el valor de los aspectos lingüísticos de la obra- argumentando, tal como lo hizo Roberto Fernández Retamar en su archiconocido Calibán (1971) que

hay razones ideológicas para tal auge [el de la linguística] más allá de la propia materia. [...] del formalismo ruso al estructuralismo francés, cuyas virtudes y limitaciones no pueden señalarse al margen de estas razones, y entre ellas la pretendida ahistorización propia de una clase que se extingue: una clase que inició su carrera histórica con utopías desafiantes para azuzar el tiempo, y que pretende congelar 
esa carrera, ahora que le es adversa, con imposibles ucronías (1998: 54).

Según Fornet, en el 71 se quebraron el relativo equilibrio que había favorecido a los intelectuales y el consenso sobre el cual se había basado la política cultural hasta ese momento: "a una etapa en la que todo se consultaba y discutía [...] siguió la de los úkases: una política cultural imponiéndose por decreto y otra complementaria, de exclusiones y marginaciones, convirtiendo el campo intelectual en un páramo" (16). Esto dio lugar, no sólo a las disrupciones en el seno de la "familia intelectual latinoamericana" sino también a uno de los momentos de mayor pobreza cultural en Cuba que el propio Fornet denominó "Quinquenio gris” y que, para Quintero Herencia, constituye la primera respuesta articulada de la cultura del poder revolucionario ante el surgimiento de una verdadera experiencia pública en la Revolución que fue resignificada en un proceso de fundación y unificación de una institucionalidad diagramada por el proyecto estatal revolucionario lo que tuvo como consecuencia el aniquilamiento de un espacio civil cuya soberanía no fuera coincidente con la promulgada por el Estado (206).

En otro orden de cosas, simultáneamente al encarcelamiento de Padilla —entre el 23 y el 30 de abril de 1971— se celebró en La Habana el Primer Congreso Nacional de Cultura en el que se postularon oficialmente los criterios ideológico-culturales del nuevo contexto cubano en relación con los intelectuales los que supusieron poner el énfasis en "la necesidad de mantener "la unidad monológica ideológica de nuestro pueblo", de combatir “cualquier forma de desviación entre los jóvenes" — “aberraciones extravagantes", “desviaciones homosexuales"” (Gilman 241-242). De este 
modo, se explicitó un tema caro a la Revolución que, aunque presente en la cultura cubana desde mucho tiempo antes, no había sido puesto en palabras — preceptos, diría mejor-, de manera tan taxativa hasta este momento en que las políticas de gobierno se vieron endurecidas en todos sus aspectos.

Las relaciones homoeróticas constituyen un aspecto de la vida personal y social del individuo sobre el que mucho se ha reflexionado y esta reflexión, fuertemente imbuida del contexto histórico-político, ha derivado en múltiples y contradictorias conclusiones que, como veremos en el capítulo III, produjo no sólo distintas formas de nominaciones sino, lo que es más importante, implicó también distintos posicionamientos políticos. Sin entrar en detalles, sólo en la época Moderna el debate se ha desplazado desde el siglo XVII en el que la sexualidad era examinada y juzgada por la Iglesia hasta el siglo XX en el que ha adquirido relevancia política y estatal. Entre ambos momentos, una amplia gama de disciplinas como la medicina, la filosofía y el psicoanálisis han ido tomando cartas en el asunto tratando de hacer sus aportes a una problemática por demás controvertida.

Por su parte, la sociedad cubana ha sido descripta y caracterizada como "tradicionalmente machista y homofóbica" y en este sentido, algunos trabajos han intentado analizar el tratamiento a los homosexuales durante período revolucionario dentro de una perspectiva histórica que comienza varios siglos antes pero que, por diversas razones, se han puesto sobre el tapete en esta última etapa de la historia cubana (Lumsden 1996: XX). Así, la regulación de género y sexo fue entendida como una medida que, para los dirigentes del gobierno castrista, pareció inevitable — principalmente en el contexto de regulación de todos los demás aspectos de la vida cubana— en 
el intento por preservar la unidad nacional y la integridad del proceso revolucionario renunciando, de este modo, a los temas de inclusión individual y derechos de minorías (XVII). González Pagés afirma que es la historia de las guerras una de las principales fuentes para determinar la masculinidad de los hombres y lo que permite que la historia nacional de Cuba repita un estereotipo universal de varón al que se le asignan valores patriarcales donde lo importante de ser varón se constituye en la diferencia que excluye a las mujeres (s/a: 2). Si bien esta postura no debe entenderse como exenta de cierto posicionamiento crítico, existe en este sentido, un conjunto de trabajos que ponen el énfasis en vincular la instauración del gobierno revolucionario desde 1959 en adelante con la institucionalización de ciertos prejuicios y prácticas discriminatorias que se manifestaron, por ejemplo, en la aparición de las UMAPs —Unidades Militares de Ayuda a la Producción - que funcionaron entre 1965 y 1968 como lugar de reclutamiento y campo de trabajo forzado para "rehabilitar" aquellas personas que fueron consideradas "antisociales" y que, aunque no se cuenta con documentación probatoria, se afirma que, en sus inicios, los recluidos fueron tratados inhumanamente (Bejel 2001: 100) $)^{11}$.

\footnotetext{
${ }^{11}$ Otra política de índole discriminatoria se implementó en las instituciones educativas en las que los alumnos eran divididos en grupos según cinco categorías de conductas consideradas problemáticas, entre los que se cuentan, junto a los niños hiperactivos y agresivos, por ejemplo, a los niños con tendencias afeminadas. Cada uno de estos grupos, denominados "brigadas", era identificado con un color y se los sometía a distintas técnicas terapéuticas en tanto se los consideraba enfermos. A los niños afeminados correspondió entonces, la "Brigada amarilla" y el método de curación consistió, entre otras cosas, en obligarlos a jugar juegos con armas que eran los considerados masculinos. De esta manera se pretendía imponer la noción de "hombre nuevo" que la Revolución consideró no sólo como aquellos que tenían altos valores morales sino también a los que demostraban rasgos de fuerza y virilidad en contraposición con la debilidad "femenina" de los homosexuales (Leiner 1994: 34). Significativamente, este procedimiento es comparable al utilizado en los campos de concentración nazis en los que, mediante un sistema de marcado de los uniformes con triángulos de colores, eran "clasificados" los distintos grupos de personas según alguna cualidad incriminante. Así, los triángulos verdes correspondían a los delincuentes, los rojos a los presos políticos, los dos triángulos superpuestos apuntando uno
} 
En este sentido, Víctor Fowler realiza un interesante trabajo que constituye uno de los primeros intentos de sistematizar las obras de tema homosexual en Cuba a través del tópico del homoerotismo en relación con la construcción de la nación. En La maldición. Una historia de placer como conquista (1998) Fowler analiza textos que, desde 1791 en adelante -primera aparición en el Papel Periódico de la Havana- dedican un espacio a "analizar, destacar, poner en solfa y condenar a los varones homosexuales cubanos" (13). Con un corpus que se extiende hasta finales del siglo XX, el autor se propone, por un lado, precisar el modo en el que la eticidad que se perfila es concebida como privilegio de una masculinidad cuyo opuesto negativo es la homosexualidad; por el otro, mostrar de qué manera la reescritura de la historia opera como un método para la revisión de los limites de la nación (28). Según Fowler, el ciudadano entrenado para defender la Revolución tiene como modelo el de aquellos héroes que enfrentaron el martirologio como destino por lo que es dable pensar que quienes mayores condiciones para soportar el sufrimiento demuestren son los que tendrán más posibilidades de inscribir su nombre en el panteón de los héroes. De este modo se instaura un relato de lo corporal que pone el énfasis en el entrenamiento del cuerpo para la defensa de la Revolución como un ordenamiento mediante el cual es obligado al olvido de sí mediante un razonado proceso de penalidades en el que el final implica una forma capaz de resistir lo indecible (27). Se trata, entonces, de un modelo masculino cuya oposición entre lo fuerte y lo débil instaura como una de sus

hacia abajo y el otro hacia arriba para los judíos y el triángulo rosa para los homosexuales (Mondimore 1998: 254). Años más tarde, en 1970, el triángulo rosa fue reclamado como símbolo de la homosexualidad representando la lucha por la igualdad hasta que casi ha sido reemplazado completamente por la menos trágicamente connotada bandera multicolor del "arco iris" (256). 
principales excrecencias a cualquier ser que incite a la asociación con lo "mujeril" y que determina los parámetros que ponen vetos a la entrada al panteón heroico (30).

Emilio Bejel, por su parte, retomando el concepto de "comunidad imaginada" de Benedict Anderson aborda también la cuestión de la homosexualidad en relación con el discurso de construcción de la nación. Bejel propone entender esa comunidad imaginada como un cuerpo —el cuerpo de la nación - que se proyecta como término positivo cuyo opuesto es el no cuerpo o la no sociedad que a menudo se representa como un cuerpo heroico desintegrado y que exige la reunión de sus fragmentos en un todo coherente a los efectos de redimirse de su propio caos y heterogeneidad aunque, necesariamente, esta redención se presenta como un constante acto de diferir la diferencia (76). Este constructo corporal es escenario de luchas de raza, clase, género y nacionalidad por lo que, analizar los discursos que se tejen en torno a estas problemáticas y en relación con la identidad nacional, forma parte de un abordaje necesario sobre el nacionalismo cubano en tanto es posible afirmar que son los discursos homofóbicos, articulados como parte de los preceptos nacionales modernos, los que, a menudo, definieron "el cuerpo homosexual" como una amenaza para la salud del cuerpo de la nación (Bejel 2001: XIV). Precisamente, esta idea de la homosexualidad como una enfermedad que amenaza al cuerpo nacional es lo que ha dado lugar a los más persistentes argumentos de la exclusión debido a que, entendida como una práctica corrupta e inmoral y, por su misma condición de enfermedad, también factible de "contagio", se hizo imperioso el alejamiento — “aislamiento" o, para usar los términos de este 
contexto, "parametraje"- de los sujetos "enfermos". Las UMAPs fueron algunas de las respuestas posibles en tanto la idea que predominó fue que la atmósfera rural en la que se obligaba a trabajar a quienes eran parametrados por su elección homoerótica constituía un ambiente propicio para curar la enfermedad que no era más que una interrupción de las leyes básicas de la naturaleza a través de la inversión de los roles genéricos naturales (102). En este sentido, uno de los principales objetivos de la Revolución fue "sanear", “limpiar" la ciudad — más precisamente, La Habana— de la inmoralidad del comercio turístico de los años del batistato, que incluía, entre otras, la prostitución, el juego por dinero y las drogas, en tanto era caracterizado como lo peor de la decadencia de la burguesía capitalista; aunque, es bueno aclarar, no sólo fue condenada la homosexualidad como antitética a la sociedad socialista sino la noción misma de libertad sexual ya que ponía en peligro la institución familiar tradicional, paradójicamente, un pilar fundamental de la misma burguesía que se pretendía atacar (Leiner 1994: $25)^{12}$

Según Bejel, a pesar y a causa de los esfuerzos por expulsar el cuerpo queer hacia lo exterior y abyecto, "el fantasma de la homosexualidad

\footnotetext{
${ }^{12}$ La vinculación de la homosexualidad con cuestiones de clase es abordada por Ricardo Llamas en Teoría torcida. Prejuicios y discursos en torno a la "homosexualidad" (1998). En este libro, Llamas explica que, en algunos casos, la necesidad de localizar la homosexualidad en un lugar distante al propio se produce en base a criterios de estructura social, económicas u origen étnico. En tal sentido, un ejemplo comparable con el caso cubano es el de la Unión Soviética que en el año 1934 criminalizó la homosexualidad bajo la tesis de que su pervivencia después de más de una década de socialismo indicaba la dificultad de erradicar completamente los restos de costumbres depravadas de las clases explotadoras enfatizando, con esto, el carácter contrarrevolucionario de tales prácticas. Por su parte, también el Partido Comunista Francés, después de los acontecimientos de Mayo del '68, se mostraba hostil con las prácticas sexuales homoeróticas en tanto las entendía como un retorno a las costumbres aristocráticas de la corte durante la época de la Regencia (110). Como ejemplo, puede mencionarse el lamentable episodio en el que, durante la ocupación de la Universidad de la Sorbona por los estudiantes, el comité de ocupación decidió poner un servicio de vigilancia en los baños para impedir posibles encuentro homoeróticos.
} 
y el simbolismo del cuerpo del homosexual ha amenazado por mucho tiempo al discurso nacional cubano" (1996: 76). Dicho de otra manera, la identidad homosexual moderna, rechazada de las definiciones del discurso nacional cubano, se transforma necesariamente en un esbozo de los límites de ese discurso en tanto como una región abyecta al margen de la narrativa cubana nacional la delimita y define, marca sus bordes y, como parte del proceso de simbolización de la nación, regresa al mundo simbólico nacional con fuerza inusual (2001: XV).

Por su parte, esta reconstrucción de la nación a partir del triunfo de la Revolución, que implementó el sistema socialista como premisa ideológica básica, también implicó la institucionalización de ciertas condiciones que tendieron a relacionar de forma directa el sistema económico con el proyecto nacionalista y la higiene social con la acción revolucionaria. Es por esto que, en tanto la homosexualidad fue entendida como una copia paródica de los roles heterosexuales y, por lo mismo, restringida al ámbito de la intimidad, los homosexuales fueron denigrados a la categoría de "gusanos" y relegados a la "gusanera" siendo ésta, en opinión de José Quiroga, una metonimia de la homosexualidad que no puede aplicarse sólo a los homosexuales como clase sino que, para la Revolución "los "gusanos" constituyen la esencia de la deposición fecal por lo que: "las heces y la analidad son el referente metonimizado de la homosexualidad" y el homosexual "la quintaesencia y el paradigma del gusano" (1998: 209-10). En tal sentido, su propuesta tiene como finalidad discutir que la homofobia en Cuba sea producto de un "atavismo cultural" previo a la Revolución. Por el contrario, Quiroga afirma que es éste un 
discurso que se politizó e institucionalizó después de 1959 a partir de las que fueron las consideraciones políticas generales del gobierno castrista, esto es: la militarización, su carácter represivo y homogeneizante y el uso de los homosexuales como escape para las frustraciones de la población (211) y por el cual "toda posible crítica gay en contrario fue sofocada, obligada a considerar su propia homosexualidad como el signo de una fatalidad, como una "diferencia maldita"” por lo que la Revolución reforzó la tragedia y el malestar que implicaba ser un homosexual (226).

La relación directa establecida entre homosexualidad y cuerpo enfermo trajo aparejada otra problemática en la que el gobierno de la Revolución también ejecutó políticas que podrían —y de hecho así lo escatalogarse como represivas e ignorantes de las más elementales premisas de derechos humanos. Se trata de los tratamientos terapéuticos aplicados a los enfermos de sida que consistieron en nuevas formas de exclusión y "parametraje", paradójicamente acompañadas de los mejores y más caros tratamientos medicinales. Si la forma en que una nación responde frente a una enfermedad como el sida revela sus valores culturales, sociales y morales más profundos, en el caso de Cuba, esta respuesta refleja las fortalezas y debilidades del sistema ya que por un lado implementó políticas de asistencia médica gratuita para todos los pacientes y por el otro institucionalizó la cuarentena haciendo de los enfermos "prisioneros en cárcel de oro" (Leiner 8). Así, la enfermedad se constituyó en "propiedad del Estado" ya que, para preservar la sociedad utópica se hizo indispensable otorgarle una forma reconocida factible de ser encerrada dentro de los límites de un sidatorio como el de Los Cocos, ubicado en el antiguo 
leprosario de San Lázaro y administrado originalmente por el ejército cubano (De Ferrari 2002: 229). Esta relación con el ejército y, consecuentemente con el Estado cubano, se afianzó desde sus inicios en tanto el sidatorio albergó, en su primer momento, a una población de soldados heterosexuales que habían participado en un conflicto militar en Angola, lo que se consolidó en prácticas de disciplinamiento tales como el uso obligatorio de pijamas azules para todos los internos y durante todo el día. Más adelante, la asociación del sida casi exclusivamente con la homosexualidad hizo que se empezara a considerar la enfermedad como una plaga comparable a la "peste negra" que diezmó la población europea en el siglo XIV, lo que justificó la aplicación de los drásticos métodos de erradicación y aislamiento (Leiner 13). 


\section{I.2. La escritura es el arte de la elipsis. Severo Sarduy, un}

\section{exiliado de sí mismo}

Como el universo, el exilio está en expansión. La realidad política por una parte y la "desertificación" anímica por la otra hacen que cada día haya más exilados. Somos tantos que ya ni nos reconocemos [...]. Sólo las antologías, redactadas por celosos guardianes del patrimonio literario nacional, dan cuenta insoslayable de esta partida. $O$ no dan ninguna. Recientemente me llamó un amigo para comunicarme la infausta noticia de que yo "no existía", al menos en los anales recientes de la literatura nacional $[\ldots]$.

Severo Sarduy, "Exiliado de sí mismo" (1990)

El tema de exilio y literatura es el tema de la literatura latinoamericana.

Emir Rodríguez Monegal, "Literatura y exilio" (1982)

Severo Sarduy nació en 1937 en Camagüey, Cuba. Su vocación literaria fue temprana y motivo de risa para el ambiente patriarcal camagüeyano de su época en el que las preocupaciones artísticas eran consideradas como una desviación peligrosa ${ }^{13}$. A pesar de las dificultades propias de una ciudad del interior, provinciana y con cierto aislamiento

\footnotetext{
${ }^{13}$ Esta problemática aparece explícitamente planteada en una escena de Colibrí en la que la voz del padre del narrador le recrimina su afición a la escritura como un estigma de homosexualidad. Ver cap. III.
} 
cultural, Sarduy hizo sus primeros acercamientos al mundo de la literatura en este ámbito, publicando sus primeros trabajos poéticos en edad muy temprana, en el periódico del pueblo ${ }^{14}$. En 1955 comenzó a vincularse con las corrientes poéticas del momento a través de algunos miembros del grupo Orígenes, formado en torno a la revista homónima que fue dirigida entre 1944 y 1955 por José Rodríguez Feo y José Lezama Lima ${ }^{15}$.

${ }^{14}$ En el año 2007 se publicó en Santiago de Cuba —aunque a mí me ha llegado muy recientemente- un libro prologado y anotado por Cira Romero en el que se recopilan los trabajos producidos y publicados por Sarduy entre los años 1953 y 1961 y que corresponden a contribuciones para distintos medios periodísticos y literarios que no habían sido reunidas aún en un libro del autor.

${ }^{15}$ Orígenes constituyó un movimiento literario y artístico que abarcó, además, varias publicaciones: Verbum (1937), Espuela de Plata. Cuaderno bimestral de arte y poesía (1939-1941), Nadie Parecía. Cuaderno de lo bello con Dios (1942-1944) Clavileño. Revista mensual de poesía (1942-1943), Orígenes. Revista de arte y literatura (1944-1956). Entre sus principales filiaciones se encuentran los poetas que conformaron la antología Diez poetas cubanos (1937-1947) que agrupó a Cintio Vitier — su realizador-, José Lezama Lima, Virgilio Piñera, Gastón Baquero, Ángel Gaztelu, Justo Rodríguez Santos, Eliseo Diego, Octavio Smith, Fina García Marruz y Lorenzo García Vega. Otro colaborador de renombre fue Roberto Fernández Retamar quien, además de participar en las publicaciones, escribió el primer estudio crítico sobre el grupo La poesía contemporánea en Cuba (19271953) (1954). Una de las principales singularidades del grupo estuvo puesta en la concepción de poesía como algo transcendental a la literatura misma, como un acto genésico, originario, como pensamiento, como sustancia de la Vida. Esta particularidad contribuyó a conformar una estética de valores universales, de atemporalidad, de trascendencia, de eternidad que es una de las causas de la oposición de Orígenes al surrealismo en particular y a los vanguardismos literarios en general en tanto estos propugnan una estética de invención y cambio incesantes (Arcos 1999: 278-80 Díaz 9120). Por esta razón, fundamentalmente, Orígenes y los origenistas fueron considerados, y criticados, como representantes de una cultura de elite. En tal sentido, Jorge Mañach inicia un debate con Lezama Lima que se extiende entre septiembre y octubre de 1949 en una carta abierta que titula "El arcano de cierta poesía nueva" en la que confiesa no entender la "jerga lezamiana". Al mismo tiempo, le reprocha al grupo no admitir la ascendencia intelectual de la Revista de Avance (1927-1930). La respuesta de Lezama fue una exposición de la política intelectual de Orígenes cuya propuesta consistía en "reconstruir la cultura cubana desde los márgenes de lo público y a través de una minoría selecta de poetas, cuyas experiencias con el lenguaje llegarían a refundar la literatura nacional" (Rojas 2006: 127). El debate también ha sido analizado por Kanzepolsky (2004) y Silva (2005). En este mismo sentido, Quintero Herencia afirma que, para Orígenes "“lo esencial poético", hasta cierto punto, lo literario, se podría postular como una zona "ritual" necesaria entre los avatares de la cotidianeidad para restañar los enigmas, vehicular los misterios gravitacionales de las "esencias" de la "identidad" cubana y latinoamericana en general" (2002: 135-6).

Salvando los enormes abismos que trazan las diferencias ideológicas y de estilo, la preocupación por la cuestión nacional es un importante punto en común de las revistas cubanas de la época también de las anteriores. Manzoni ha analizado el problema con exhaustiva lucidez en la Revista de Avance (Manzoni 141-181; 249-277). Luego, Quintero Herencia desarrolla las relaciones que se pueden establecer en este sentido entre Orígenes y Casa de las Américas en el trabajo ya mencionado. 
En 1956 se trasladó a La Habana con el fin de matricularse en la Facultad de Medicina de la Universidad pero lo que en realidad trajo aparejado este traslado a la capital fueron nuevas incursiones en el mundo del arte y las letras ya que no sólo se dedicó a trabajar en una agencia publicitaria sino que, además, comenzaron sus relaciones con escritores y revistas en las que luego adquiriría relevancia insoslayable, tales como Ciclón, una de las revistas cubanas de mayor importancia — si no la más importante- de ese momento ${ }^{16}$. De la misma manera, comienza en estos años su trayectoria como crítico publicando una nota sobre una colección de ensayos de Lezama Lima, Tratados en La Habana (1958) en la que, si bien es positiva, deja entrever un tono de condescendencia como de quien ha superado a sus mayores — del que luego, de alguna manera, dará muestras de arrepentimiento- - y haciéndose eco, de este modo, de las críticas que los jóvenes de Ciclón proferían contra sus mayores origenistas en un intento no sólo de ponerse al corriente de la literatura hispanoamericana y europea del momento sino también de diferenciarse de los que formaban parte de la

\footnotetext{
${ }^{16}$ Ciclón. Revista Literaria Bimestral apareció entre los años 1955 y 1959 en La Habana bajo la dirección de José Rodríguez Feo. Contó entre sus principales colaboradores a Virgilio Piñera (secretario), L. Marré, N. Tejera, S. Sarduy, Julio Rodríguez Luis, A. Arrufat (Arcos 1999: 273). Una de las críticas más fuertes de Ciclón con respecto a los origenistas se basó en el carácter político -en tanto directamente vinculados con el proceso revolucionario- de los primeros en contraposición a una postura que, impregnada de misticismo católico y nacionalista parecía alejarse de la complejidad de la realidad al punto de que planteos como los de Vitier en Lo cubano en la poesía (1958) o La expresión americana (1957) de Lezama Lima constituyen puntos álgidos para el debate posterior ya que son intentos totalizadores de construir la cubanidad como esencia homogénea a costa de suprimir y opacar las multiplicidades que la constituyen. De donde son los cantantes es una de las muchas versiones mediante las cuales se mantuvo este debate acerca de la nacionalidad cubana. Ver. Cap.II.

Otro punto de discrepancia entre ambas revistas refiere a la aparición de la sexualidad, especialmente de la homosexualidad, en textos como el de Piñera "Ballagas en persona" aparecido en el $\mathrm{N}^{\circ} 5$ de Ciclón de septiembre de 1958 (283).

Para un análisis detallado de las tensiones entre ambas revistas, véase Duanel Díaz (125185).
} 
generación anterior ${ }^{17}$. Estas actividades le permitieron relacionarse con escritores de la talla de Guillermo Cabrera Infante, Lisandro Otero, Roberto Fernández Retamar, Heberto Padilla, Pablo Armando Fernández y Edmundo Desnoes, entre otros, quienes, aunque compartieron un mismo entusiasmo revolucionario al comienzo del gobierno castrista, poco a poco y a medida que la Revolución se fue afianzando y, consecuentemente, "endureciendo", fueron adoptando distintas y hasta contradictorias posturas al punto de constituir casos extremos como el de la crítica feroz de Cabrera Infante o la degradación pública que debió sufrir Padilla en contraposición con la anuencia sostenida, aún hoy, por Fernández Retamar con las políticas del gobierno revolucionario.

A partir del año 1959, triunfo de la Revolución e inicios del gobierno de Fidel Castro, Sarduy se convirtió en uno de los jóvenes intelectuales con mayor interés del período. Es en ese momento, entonces, cuando comienza a publicar en el periódico Revolución —órgano del Movimiento 26 de Julio, dirigido por Carlos Franqui- en el que participaban aquellos jóvenes que habían luchado contra la dictadura de Batista. En marzo de ese mismo año se creó Lunes de Revolución que tuvo como primer director a Cabrera

\footnotetext{
${ }^{17}$ Además de las alusiones que aparecen como homenajes velados en la obra novelística, Sarduy dedicó varios ensayos al reconocimiento de la obra lezamiana: "Dispersión. Falsas notas/ Homenaje a Lezama" (1967). "El heredero" (1988), "Imágenes del tiempo inmóvil" y "Pas de deux", ambos de 1991.

En "El heredero" Sarduy afirma: "LEZAMA es, en nuestro espacio, ese antecesor; es su obra la que, desde el porvenir, regresa o invita a que la convoquemos para que en su advenimiento ese porvenir se haga presente" [Mayúsculas en el original] (1999 [1988]: 1405). A lo que agrega poco más adelante: "Heredar a Lezama es practicar esa escucha inédita, única, que escapa a la glosa y a la imitación. Adivinar más que descifrar; incluir, injertar sentido, aún si detrás del juego de sus jeroglíficos el sentido es un exceso, una demasía, y que, precisamente, como el paisaje, esos signos conocen por su amplitud, por esos dones sobrantes; desconstruir, más que estructurar. [...] Así lo intenté, al proyectar en una ficción, la novela Maitreya, un personaje secundario, Luis Leng, que ocupa apenas unas líneas de Paradiso" (1412-3). Los límites y posibilidades de esta relación han sido analizados por Guerrero (1997); Ponte y Silva (2008).
} 
Infante y en el que Sarduy tuvo la responsabilidad de ser el crítico de artes plásticas, aunque algunas de estas colaboraciones las hizo desde París, ciudad en la que recaló becado por la Dirección de Cultura para estudiar crítica de arte en la Ecole du Louvre. Ya desde este momento y desde este lugar, Sarduy hizo sus primeras afirmaciones a favor de un arte figurativo y en contra de un arte concreto con supuestas "preocupaciones sociales" que más tarde, con el endurecimiento de las políticas culturales, se convertiría en precepto bajo la forma de "realismo socialista".

En 1961, cuando se cumplió el plazo de la beca, Sarduy aún no había terminado sus estudios y ésta fue una de las razones por las cuales decidió permanecer en Francia, aunque es posible inferir que otras —más ideológicas y profundas - son las que lo mantuvieron definitivamente en ese país hasta su muerte en el año 1993. Este exilio relativamente voluntario —que lo hace decir que más que un exiliado es un "quedado"— se debe, pero, al mismo tiempo, provoca, un alejamiento paulatino de Sarduy con respecto al gobierno de la Revolución ya que, si bien es cierto que nunca estableció una relación abiertamente conflictiva con éste como fue el caso de Cabrera Infante o el más flagrante de Heberto Padilla, también es verdad que tanto su inclinación estética como su elección homoerótica lo alejaron del canon de la intelectualidad cubana al punto que fue excluido de entre los nombres de la literatura nacional ${ }^{18}$.

Ya en París, Sarduy estableció relaciones con figuras como las de François Wahl y Roland Barthes, en particular y, en general, con todo el

\footnotetext{
${ }^{18}$ Los ataques explícitos por parte de algunas figuras oficiales del gobierno castrista se empezaron a dar hacia fines de los años sesenta y en diversas oportunidades. Por parte de Sarduy, en mi opinión, las críticas aparecen en sus novelas aunque no de manera explícita y mucho menos factible de ser tildadas de panfletarias.
} 
grupo Tel Quel que tuvo una relevancia singular en su obra narrativa, principalmente, en novelas como Cobra (1972) y Maitreya $(1978)^{19}$.

Si el exilio ha sido una constante histórica en América Latina que cobró visos de masividad a partir de la segunda mitad del siglo XX a raíz de la instauración de gobiernos dictatoriales y sus consecuentes exclusiones ideológicas y económicas, en Cuba no lo ha sido menos. Sin embargo, es necesario advertir que en este caso ha tenido características particulares que agregaron un plus de complejidad a la que ya es inherente a esta problemática ya que fueron posturas políticas disímiles y enfrentadas entre sí las que provocaron la mayor masa de exiliados: por un lado, el gobierno de Fulgencio Batista, de tendencia derechista; más tarde, el gobierno de Fidel Castro, que significó la institucionalización del proceso revolucionario basado en políticas de izquierda y con un muy fuerte anclaje en el Partido Comunista. En virtud de esto, también el recibimiento que tuvieron estos exiliados en los países que los acogieron tuvo sus particularidades en tanto, a excepción de los que se refugiaron en Estados Unidos, los exiliados del régimen castrista han sido blanco de polémicas y cuestionamientos en más de una ocasión. En tal sentido, Jacobo Machover afirma: "El exilio cubano es absolutamente distinto, en lo que concierne a su recepción, de los demás exilios latinoamericanos. La desconfianza en relación con los fugitivos del régimen castrista era (y todavía es) la norma” (2001:18).

\footnotetext{
${ }^{19}$ Además de Tel Quel, Sarduy participó asiduamente, durante su estancia en Europa, en una gran cantidad de publicaciones, entre otras, Mundo Nuevo y Quinzaine Littéraire de Francia; Sur, El Mundo, Primera Plana y El Cielo de Argentina; Zona Franca e Imagen de Venezuela; Diálogos y Revista de la Universidad Autónoma de México; Hispamérica, Point of Contact, Escandalar y Revista Iberoamericana de Estados Unidos, etc (López Lemus 1997: 84).
} 
Por otra parte, el proceso revolucionario, que se definió desde sus comienzos como una lucha a favor de los intereses del pueblo cubano y se consolidó con el apoyo y la participación activas de éste, contó también con el beneplácito de la gran mayoría de los intelectuales, sobre todo, de aquellos que hacían sus primeras armas en el mundo del arte y las letras bajo el amparo de la juventud, quienes se vieron también contagiados por la exaltación no sólo de lo llegado sino especialmente de lo porvenir. Sin embargo, cuando la realidad del proceso pareció ya no estar a la altura de las expectativas y comenzó a producirse la ruptura entre estos intelectuales y el gobierno de Castro fue cuando el exilio adoptó nuevas y controvertidas formas. Así, son paradigmáticos y harto conocidos los casos de Reinaldo Arenas y Guillermo Cabrera Infante ${ }^{20}$.

El primero, logró exiliarse en Estados Unidos después de una larguísima y penosa huida de la persecución y la censura que le impidieron no sólo desarrollar su talento artístico sino también, y muy especialmente, vivir su elección homoerótica con libertad. Su escritura plasmó desde los inicios esta constante y no fue menos aguerrida en sus denuncias al final de su carrera, por lo que se puede afirmar que Arenas mantuvo una coherente postura de marginalidad y enfrentamiento con las políticas castristas a lo largo de toda su obra transformándose, de esta manera, en un símbolo de la persecución a los homosexuales en Cuba.

\footnotetext{
${ }^{20}$ Jacobo Machover realiza un trabajo comparativo entre la obra de Cabrera Infante, Arenas y Sarduy tomando como eje de sus reflexiones el carácter de exiliados de sus autores y las distintas posturas y formas de asumir sus exilios. A pesar de que Machover se concentra en estos tres escritores, a quienes considera paradigmáticos en función de sus tres respuestas diferentes y alternativas al gobierno castrista, no deja de reconocer que esta problemática, en Cuba, se repite a lo largo toda su historia social y cultural por lo que cita otros exiliados ilustres entre los que se cuentan como los primeros en irse después del triunfo de la Revolución, a la cantante Celia Cruz, la antropóloga Lydia Cabrera, el poeta Gastón Baquero, el escritor Lino Novás Calvo, Miguel Ángel Quevedo, Néstor Almendros (2001: 17).
} 
Cabrera Infante, por su parte, tuvo una trayectoria que pasó del apoyo explícito a la Revolución por el que ocupó lugares de importancia en las políticas culturales del gobierno castrista al exilio londinense desde el cual mantuvo una postura de rotundo y manifiesto enfrentamiento hasta su muerte. Su cambio significó, junto a los que estuvieron involucrados en el "caso Padilla", una de las rupturas más profundas y estridentes que se produjeron entre el campo intelectual y el campo político en la Cuba postrevolucionaria.

El exilio de Sarduy, en cambio, es menos proclamado y, al parecer, también menos controvertido que los casos anteriores. Como dije, se fue a París en 1959 pero no como un exiliado disidente con la causa sino, en tanto becario el gobierno de Castro, bien podría decirse que en una posición privilegiada que mucho lo asemejaba a una especie de embajador cultural.

Como Cabrera Infante, Sarduy fue uno de los tantos escritores favorables a la Revolución en sus comienzos pero esta relación cambió considerablemente con el paso del tiempo aunque menos por la actuación propia del escritor que por las políticas culturales del gobierno de Castro que lo excluyeron del canon de la literatura nacional aun sin haberse registrado una participación activa de Sarduy en posiciones o acciones anticastristas. Por el contrario, aunque formó parte de proyectos como el de la revista Libre no asumió lugares preponderantes de enfrentamiento o ruptura y sus críticas no fueron declaraciones o manifestaciones públicas sino que formaron parte del humor, la ironía o la parodia presentes de modo sutil, casi velado, en su obra narrativa. Su posicionamiento explícito ha sido el de un "quedado", o un "aislado", no el de un exiliado involuntario: "Me 
quedé así, de un día para otro. Quizás vuelva mañana” (1990: 42). Claro que, me atrevo a afirmar, esto no constituye más que un guiño pícaro de complicidad para con un lector- receptor que sabe, o por lo menos intuye, que su historia no podría haber sido de otra manera, que el regreso físico a la Cuba de los años duros del castrismo era, para un escritor de las características de Sarduy, si no imposible, al menos indeseable y, hasta cierto punto, probablemente peligroso en tanto ni adoptó la estética del realismo socialista como modo de reseñar la problemática de la realidad cubano/ latinoamericana ni afianzó los parámetros de un héroe coherente, monolítico, íntegro. Por el contrario, asumiendo la estética neobarroca en consonancia con los postulados teóricos del post-estructuralismo y desde su elección homoerótica, produjo un relato disidente de las narraciones identitarias homogeneizadoras que se sustentó en la construcción de una subjetividad quebradiza, fragmentada, contradictoria, inestable. Dicho de otro modo, una subjetividad que puso el énfasis en la escritura disruptiva, inquietante, del gozo, el exceso y el desperdicio y en el cuerpo como un soporte textual sobre el cual escribe y lee incontables garabatos y cicatrices de su vida personal y social —entre ellas, la más importante, la de la enfermedad, el sida - y su propia configuración de sujeto "exiliado" — exiliado de su cuerpo, su historia, su tiempo, su lugar, su literatura, "exiliado de sí mismo"... 


\section{3. La escritura es el arte de descomponer un orden y componer un desorden: Francia, Tel Quel y el discurso sobre \\ el sujeto}

y así tomé conocimiento por ello que yo era una sustancia cuya esencia y naturaleza toda consistía en el pensar, y que no necesitaba, para existir, de lugar alguno, ni depender de cosa material alguna; de suerte que este yo, es decir, el alma, por la cual yo soy lo que soy, sea enteramente distinta del cuerpo y hasta más fácil de conocer que éste y, aunque el cuerpo no existiese, el alma no dejaría de ser lo que ella es.

René Descartes, Discurso del método

Cuba fue para Sarduy no sólo el lugar de nacimiento y el contexto de producción de sus primeras escrituras sino, especialmente, un tema, un problema, una obsesión. De ahí su importancia insoslayable como horizonte nunca perdido pero también, y en tanto tal, nunca alcanzado. El alejamiento impone, entonces, otro lugar, otros temas —o, por lo menos, otras formas de abordarlos - otro contexto de producción: Francia, París, Tel Quel y una historia conceptual que dio lugar a una de las masas teóricas más ricas y discutidas en las últimas décadas del siglo $\mathrm{XX}$.

Por demás conocida, la premisa cartesiana que impone el "pienso, luego existo" es fundamento y síntesis de la filosofía y el pensamiento modernos. En ella se resume una concepción que entiende la subjetividad como una esencia que se sustenta por y para la Razón -valgan las mayúsculas por el lugar que se le otorga- y en la que el cuerpo es poco más 
que un soporte, elemento subsidiario del alma. Dicho de otra manera, René Descartes en su Discurso del método (1637) elabora lo que podría denominarse el "principio de racionalidad" que constituye una característica común a todos los hombres susceptible de ser empleada mediante la aplicación de un método preciso que tiene sus fundamentos en la acción de dudar y que establece jerarquías naturales e indiscutibles en las que Dios, la Razón y la Verdad son los elementos fundantes de una larga cadena consecutiva y "lógica".

Así, si el individuo existe en razón del pensamiento que lo hace dudar, Descartes concluye que, en tanto ser dubitativo, es imperfecto. Pero como ha aprendido a pensar y esto es improbable que surja de la nada se ve obligado a indagar en torno a la idea de la existencia de una naturaleza superior, perfecta, de la que pueda surgir este pensamiento. De manera que concluye que "sólo quedaba que hubiese sido puesta en mí por una naturaleza verdaderamente más perfecta que la mía [...] para explicarlo en una palabra, que este ser fuese Dios" (2005 [1637]: 40). Y si todas nuestras ideas y nociones, claras y distintas, proceden de Dios, continúa el argumento cartesiano, no pueden ser sino verdaderas (43).

De tal modo, la Razón cobra el carácter de instrumento supremo para la verdad oponiéndose tanto a la imaginación como a los sentidos e instituyendo una nueva oposición binaria - como sucede con el par cuerpoalma- en la que uno de los elementos quedará arbitrariamente relegado hasta el siglo XX cuando este sistema de dicotomías excluyentes propio del pensamiento moderno comience a ser fuertemente cuestionado y la 
subjetividad deje de ser pensada como una sustancia ya dada de una vez y para siempre.

Sin duda, fue Sigmund Freud uno de los principales iniciadores de estos cuestionamientos y el que, además, dará lugar a una vastísima tradición teórica en la que se reconocerán sus aciertos tanto como se discutirán sus equívocos pero que, de ningún modo, permanecerá ignorado. Una de sus más importantes contribuciones está directamente ligada a la organización tópica de la psique humana, a partir de la cual Freud, aborda sus estudios y que será fundante para todo el pensamiento psicoanalítico aún cuando sea sometida a debate o entendida de manera algo diferente tal como sucede en la obra, por ejemplo, de Jacques Lacan.

Como premisa básica, el psicoanálisis, según Freud "no puede situar en la conciencia la esencia de lo psíquico, sino que se ve obligado a considerar la conciencia como una cualidad de lo psíquico que puede añadirse a otras cualidades o faltar" (1997 [1923]: 15) por lo que esta organización estructural contiene tres elementos -consciente, preconsciente e inconsciente- que, no sólo cumplen funciones disímiles entre sí sino que, además, tienen características distintas y operan también de manera diferenciada.

De estos tres elementos, indudablemente, es el inconsciente el que impone los principios para un profundo cuestionamiento al sujeto cartesiano como totalidad fija, indivisible y permanente. En una primera instancia, Freud distingue entre dos tipos de inconsciente: lo latente, susceptible de conciencia, por un lado, frente a lo que no es susceptible de conciencia que constituye lo reprimido, es decir, aquellas representaciones, o puesta en 
imágenes de las pulsiones, que a través del mecanismo de la represión tienen denegado el acceso a la conciencia. En una segunda instancia, la noción de inconsciente quedará limitada exclusivamente a lo reprimido en tanto incorpora el término preconsciente para designar lo que es el inconsciente sólo descriptivamente y no en el sentido dinámico, es decir, aquello que permanece latente y capaz de volver a la conciencia (17). Es por esto que, si bien todo reprimido es inconsciente, no todo inconsciente es reprimido (19).

La función primordial del inconsciente consiste en deformar o disfrazar el sentido, hasta volverlo irreconocible, mediante cuatro mecanismos que son la condensación, el desplazamiento, el miramiento por la figurabilidad y la elaboración secundaria (Elliott 1995: 44). De éstos, interesan aquí, particularmente, los dos primeros, en razón de que serán retomados por Sarduy en su conceptualización sobre el neobarroco, aunque con otra terminología y no sin haber pasado previamente por el tamiz de las teorías lacanianas.

La condensación es uno de los modos de funcionamiento esenciales de los procesos inconscientes. En un primer momento, Freud la describió en La interpretación de los sueños (1900), pero también fue un elemento relevante en el análisis del chiste, del lapsus linguae y del olvido de palabras que desarrolló en Psicopatología de la vida cotidiana (1901) y El chiste y su relación con lo inconsciente (1905). La condensación es una característica del pensamiento inconsciente por la que el deseo queda sometido desde un principio a ella. Constituye, a la vez, un efecto de la censura y una forma de escapar de ella en tanto dificulta la lectura del relato 
manifiesto porque éste resulta conciso en comparación con el contenido latente, es una versión abreviada de éste: "El sueño es escueto, pobre, lacónico si se lo compara con la extensión y la riqueza de los pensamientos oníricos" (1996 [1900]: 287). El desplazamiento, por su parte, es otro modo de funcionamiento psíquico que, al igual que la condensación, Freud analiza especialmente en relación con la interpretación de los sueños. Constituye un proceso por medio del cual en el trabajo onírico "se exterioriza un poder psíquico que por una parte despoja de su intensidad a los elementos de alto valor psíquico, y por la otra procura a los de valor ínfimo nuevas valencias por la vía de la sobredeterminación, haciendo que estos alcancen el contenido onírico" [Itálicas en el original] (313). Como consecuencia de este desplazamiento, el sueño ya no presenta el mismo aspecto que el núcleo de los pensamientos oníricos sino que sólo refleja una desfiguración —dislocación- del deseo onírico del inconsciente (314): “El sueño está por así decir diversamente centrado, y su contenido se ordena en torno de un centro constituido por otros elementos que los pensamientos oníricos" [Itálicas en el original] (311).

De este modo, para el psicoanálisis freudiano, el saber consciente de los humanos se ve limitado por estas estructuras psíquicas reprimidas por lo que el sujeto se presenta dividido y fracturado por el deseo inconsciente (Elliott 1995: 45). La existencia psíquica, entonces, nace de una escisión y una represión por lo que de a poco y precariamente la realidad psíquica adquiere organización como subjetividad formada. Dicho de otra manera, lo decisivo para la constitución de la psique es la disyunción entre los instintos de conservación y la emergencia de los impulsos sexuales (38). 
La conciencia, por el contrario, es la superficie del aparato anímico constituida por las percepciones que nos vienen de afuera -percepciones sensoriales-, los sentimientos y las sensaciones (Freud 1997 [1923]: 21). Indagar acerca de cómo algo deviene consciente implica, para Freud, preguntarse primero cómo deviene preconsciente. La respuesta está en la conexión con las representaciones- palabra, es decir, en los restos mnémicos que alguna vez fueron percepciones y que, como todos los restos mnémicos, pueden devenir nuevamente conscientes (22).

Esta tópica freudiana que organiza la psique en consciente, inconsciente y preconsciente tiene su correspondencia en tres instancias de personalidad: yo, ello y superyo. El ello es la fuente de los impulsos libidinales, en él se sitúa el inconsciente en tanto confluye allí lo reprimido. Sin embargo, esto no significa que éste sea su espacio restringido. Por el contrario, también en el yo Freud reconoce una parte del inconsciente ya que lo reprimido "sólo es segregado tajantemente del yo por las resistencias de represión, pero puede comunicar con el yo a través del ello" (26). Así, el yo es la parte del ello alterada por la influencia directa del mundo exterior y se empeña en hacer valer sobre el ello este influjo para reemplazar, de esta manera, el principio de placer que rige en el ello por el principio de realidad: "El yo es el representante de lo que puede llamarse razón, por oposición al ello, que contiene las pasiones" (27).

Sin embargo, esto no es todo lo que constituye el yo sino que existe dentro de él una diferenciación que Freud denomina "ideal del yo" o "superyo" tras la cual se esconde la primera identificación del individuo que es la identificación con el padre (33) de tal manera que esta instancia enlaza 
de forma directa con el complejo de Edipo. El resultado de la fase sexual gobernada por el complejo de Edipo es la sedimentación en el yo de dos identificaciones -la identificación- padre y la identificación- madre-, las cuales, unificadas entre sí, se enfrentan al otro contenido del yo como ideal del yo o superyo. Como consecuencia, el superyo no es sólo residuo de las primeras elecciones de objeto sino que tiene la significatividad de una formación reactiva que no se agota en la advertencia sino que implica también la prohibición. Así, “cuanto más intenso fue el complejo de Edipo y más rápido se produjo su represión [...] tanto más riguroso devendrá después el imperio del superyo como conciencia moral, quizá también como sentimiento inconsciente de culpa sobre el yo" (36). El ideal del yo es, entonces, heredero del complejo de Edipo ya que, mientras el yo es esencialmente representante del mundo exterior, el superyo se le enfrenta como "abogado del mundo interior, del ello" (37) por lo que, y en tanto encarnación de la ley, constituye una instancia de fuerte dominación y represión del sujeto. De esta manera, Freud pone de manifiesto que la identidad se constituye por la introyección y represión de las formas de roles sociales y sexuales de la sociedad con lo cual surge, en opinión de Elliott, una de las intelecciones políticas más interesantes de la obra freudiana que es la demostración de que la ley se funda en el deseo en tanto la introyección de las prohibiciones culturales es resultado directo de las primeras elecciones de objeto del ello (67).

Si el psicoanálisis freudiano constituyó un hito fundamental en los procesos de cambio del pensamiento sobre la problemática del sujeto hacia comienzos del siglo XX, está claro que el otro gran hito a este respecto se 
dio a partir de la segunda mitad del mismo siglo, esto es, más precisamente, desde la década del sesenta en adelante.

Tal como lo precisa Eric Hobsbawm (1998), entre la guerra de 1914 y el fin de la Segunda Guerra Mundial se extiende un período que puede calificarse como época de catástrofes —económicas, políticas, humanitarias-. Sin embargo, la segunda posguerra no se presentó de la misma manera, al menos en lo que concierne a los aspectos financieros, en tanto comenzó, en 1945, una etapa de crecimiento económico, de industrialización y desarrollo que implicó, a su vez, una profunda transformación social (15). Esta etapa estuvo signada por un largo proceso de independización que tuvo como protagonistas una serie de acontecimientos violentos -luchas en Vietnam desde 1945, la liberación de China (1949), Egipto (1952), Argelia (entre 1958 y 1964) y finalmente, la Revolución cubana (1959)- pero también por el resurgimiento y reconfiguración de ideas socialistas, marxistas, nacionalistas, de las vanguardias armadas y las masas populares (Casullo 1997). Es éste un tiempo contestatario que cuestiona las bases mismas del mundo en el protagonismo de un sujeto social, político e ideológico, aún claramente constituido, que tanto se organiza en torno a revueltas -estudiantiles, campesinas, obreras - como a proyectos de producción artística e intelectual:

La provocación, la posibilidad de ruptura, la utilización del lenguaje fuerte, el lenguaje inconciliador. La palabra desbordando las normas institucionales, la palabra mala, la mala palabra como revelación de una realidad de opresión, frente a las buenas palabras simuladoras. La lucha en el plano del lenguaje, legal y prohibido, reconocido y en falta, es también lucha cultural. El plano del discurso, en 
todas sus manifestaciones, va a ser parte de las contiendas de los años `60 (175).

En este contexto surgió, en marzo de 1960, el primer número de la revista Tel Quel y, en torno de ella, un grupo de intelectuales, algunos ya con una reconocida trayectoria como la de Roland Barthes, que se reunieron no con la finalidad última de editar la revista sino de crear un espacio - "el espacio Tel Quel" como lo denomina Manuel Asensi Pérez (2006)- que resultara un ámbito productivo de debate y confrontación. Si bien uno de los focos de las polémicas estuvo puesto en la figura de Jean- Paul Sartre y en sus teorizaciones sobre el existencialismo y el compromiso de la literatura, es importante reconocer que ya desde el comienzo Tel Quel se propuso como un espacio contradictorio y ecléctico capaz de configurarse como un gran centro generador de importantes y profundas controversias. De tal modo queda explicitado en la "Déclaration" que abre el primer número ${ }^{21}$ :

No se puede esperar de la definición de un grupo tan diverso y formado (felizmente) de personalidades contradictorias, una precisión más grande. Toda toma de conciencia demasiado categórica será poco más que un manifiesto individual. Pero se advertirán los silencios y las omisiones. Quizá, estos serán flagrantes. Quizá involuntarios (...) nada, en definitiva nos sería más grato que ser acusados de eclecticismo (citado en Asensi Pérez 2006: 56).

A pesar de la advertencia, fueron estos silencios, precisamente, una de las mayores fuentes de críticas que debió soportar el grupo ya que fueron interpretados como marcas de falta de compromiso con su tiempo y sus circunstancias. Así se entendió, por ejemplo, el no haber asumido una

\footnotetext{
${ }^{21}$ En esta declaración inicial, aparece una primera respuesta polémica al libro Qu'est-ce que la littérature (1948) de Sartre en tanto, frente a la propuesta sartreana que subordina la literatura a su utilidad en el mundo, los telquelistas se oponen con una puesta del énfasis en el lenguaje, en una primera instancia estructuralista (2006: 57-8). También este hecho fue entendido, en más de una ocasión, como una actitud descomprometida y apolítica.
} 
posición política explícita con respecto a la guerra de Argelia (58). Sin embargo, tal como lo expresa Asensi Pérez, la política en Tel Quel no residía en las postulaciones definitivas ni en las declaraciones grandilocuentes sino en el cambio, el debate y la controversia, en el cuestionamiento y la difuminación de los absolutos: "la máquina Tel Quel consistió en no permanecer idéntica a lo largo de su historia, en no ser la misma, en hacer del cambio una estrategia política" (71) y en situarse al margen, en disidencia, como excepción de todos los dogmas (472).

Estrechamente relacionado con el grupo Tel Quel, Jacques Lacan fue uno de los teóricos que más elementos aportó al debate sobre la subjetividad en este período y los siguientes en tanto, como su antecesor y, en algunos casos en discusión con él, estableció los fundamentos psicoanáliticos que aún hoy constituyen una base ineludible para los estudios en las ciencias humanas. La vinculación de Lacan con Tel Quel comenzó en el año 1966 con la publicación del libro Écrits ${ }^{22}$. A partir de ese momento, se estableció una relación en la que el psicoanálisis se convirtió en un elemento fundamental dentro de las teorizaciones de los integrantes del grupo aún cuando algunos de ellos se expresaran en términos freudianos o antilacanianos. Una clave del acercamiento de Lacan a Tel Quel está dada por la dimensión estructuralista de su teoría así como su preocupación por el lenguaje y los problemas del significante y del orden simbólico. Esta relación, que se fue estableciendo lenta y paulatinamente, se consolidó en 1969 cuando fue expulsado de la École Normale Supérieure, donde dictaba

\footnotetext{
${ }^{22}$ Algunos temas abordados en este libro son variaciones de textos anteriores, por ejemplo, "el estadio del espejo" en el que estuvo trabajando durante por lo menos tres décadas.
} 
sus seminarios a los que asistieron muchos de los telquelistas, a raíz de lo cual recibió el apoyo y la ayuda de Tel Quel (Asensi Pérez 81-3).

Tres nociones esenciales, que son los tres órdenes en que se estructura la psique según Lacan, es necesario tener en cuenta a la hora de abordar su teoría. A saber: el orden imaginario (preedípico, es decir, anterior al inconsciente) constituye un universo de ilusiones distorsionadas, imágenes y engaños que se forma a través de una superficie reflejante (el espejo); el orden simbólico, por su parte, corresponde al plano de los sentidos sociales tradicionales, de la diferenciación, de la individuación ${ }^{23}$. En este orden, cumple una función central el lenguaje ya que, reprimiendo las trampas imaginarias y las imágenes especulares del orden imaginario, constituye la estructura del inconsciente. Finalmente, el orden real es aquel aspecto de la realidad que hace resistencia al juego especular y a los intentos de simbolización al mismo tiempo. Se sitúa más allá de la representación y se vincula con el deseo y la pulsión de muerte (Elliott 1995: 164-5).

El orden de lo imaginario, según Lacan, es el ámbito donde aún no se ha producido la escisión entre sujeto y objeto. Sin embargo, cuando el infante reconoce su propia imagen en un espejo, capta una imagen de unidad corporal que se sitúa en contraste con el estado fragmentario de su cuerpo real y esta escisión señala que el yo está segregado de otros. Esto constituye lo que Lacan denomina "el estadio del espejo" que "nos opone [al psicoanálisis] a toda filosofía derivada directamente del cogito (2007 [1966]: 99) y al que es necesario comprender como una identificación, en el

\footnotetext{
${ }^{23}$ Para un posible abordaje a la cuestión del orden de lo imaginario, ver Evans, Dylan. Diccionario introductorio de psicoanálisis lacaniano. Buenos Aires: Paidós, 1997: pp. 10910. Para "el estadio del espejo" ver en el mismo diccionario las páginas $81-2$ y para el orden de lo simbólico páginas 179-80.
} 
sentido pleno de este término, que constituye un caso particular de la función de la imago consistente en establecer una relación del organismo con su realidad (100): "el estadio del espejo es un drama cuyo empuje interno se precipita de la insuficiencia a la anticipación" ya que, para el sujeto, "maquina las fantasías que se suceden desde una imagen fragmentada del cuerpo hasta una forma que llamaremos ortopédica de su totalidad $-\mathrm{y}$ hasta la armadura por fin asumida de una identidad alienante que va a marcar con su estructura rígida todo su desarrollo mental" (103). El momento en que termina el estadio del espejo es el que inaugura la dialéctica que liga al yo con situaciones socialmente elaboradas y el que vuelca todo el saber humano en la mediatización por el deseo del otro y "hace del yo [je] ese aparato para el cual todo impulso de los instintos será un peligro" (104). Sin embargo, esta escisión primordial entre el cuerpo real del niño y su imagen especular indican que el yo está definitivamente separado de otros por lo que "el propio ser lacaniano se sitúa desde el principio en el interior de un espacio imaginario dañino, inserto en una escisión radical entre un sentir ilusorio de personalidad y algo que es profundamente otro" (Elliott 170). Dicho de otro modo, el sujeto se funda en la fisura de una escisión radical por lo que las identificaciones imaginarias del estadio del espejo se constituyen como un vínculo de alteridad, provocado por la disensión entre su forma exterior coherente y su sentimiento de fragmentación, que lo empuja hacia un desconocimiento alienante de su propia verdad $(171)^{24}$. Estas experiencias tempranas de

\footnotetext{
${ }^{24}$ El "estadio del espejo", como fase en la que se produce la identificación primaria con el propio ser, constituye una de las diferencias fundamentales entre las teorías lacanianas y los postulados de Freud ya que, en tanto para Lacan esta identificación no nace del inconsciente - simplemente porque no hay insconsciente antes del lenguaje- sino de
} 
fragmentación se centran en objetos que sólo existen como objetos faltantes y que desempeñan un papel constitutivo en la estructuración de la psique. Este objeto, que Lacan denomina pequeño objeto $a$, designa una parte cualquiera del cuerpo a condición de que no haya sido espejada ni simbolizada por lo que denota la introyección de imágenes y signos que siempre escapan al conocimiento del sujeto. El objeto $a$, que se encuentra en el nudo de los tres registros, constituye una conjugación de cuerpo, deseo y significantes que causa las fantasías imaginarias que suturan la hiancia constitutiva de la subjetividad humana, aunque la vivencia primaria del cuerpo fragmentado obtura para siempre al sujeto la posibilidad de establecerse en un todo coherente y completo (172).

En una segunda instancia, la elaboración teórica lacaniana pone el énfasis ya no tanto en lo imaginario como en las faltas que estructuran al sujeto a nivel del inconsciente pero dentro de un nuevo orden, el simbólico que, en tanto se formaliza, según Lacan, en torno al lenguaje, constituye uno de los mayores acercamientos de las teorías psicoanalíticas al estructuralismo y, consecuentemente, un punto de relativo alejamiento con respecto a Freud. En este sentido, nuevamente juega un papel de primordial importancia la conceptualización del inconsciente ya que, si para Freud constituye las representaciones de las pulsiones que tienen denegado el acceso a la conciencia pero que pugnan por salir, en la concepción lacaniana el inconsciente es "una estructura lógica de elementos diferenciales" (174). De esta manera, se establece una relación ineludible con el lenguaje ya que éste se instituye como un elemento fundamental en la estructuración de la 
psique en tanto es considerado por Lacan como un sistema organizado y preexistente que no está estructurado por el inconsciente sino que, por el contrario, lo estructura y lo integra en un orden lingüístico (176-7) que, según Fredric Jameson (1995) se puede caracterizar organizándolo en tres grupos.

El primero constituye la función nominal que implica los sustantivos y pronombres y que resulta una transformación radical de la posición del sujeto en su mundo de objetos $(27)^{25}$. En tal caso, el sujeto aparece representado por un doble o sustituto que es del orden del símbolo o del significante y que sólo es perpetuado lateralmente por medio de las relaciones de ese significante con otros significantes. De este modo, el sujeto mediado por el lenguaje se encuentra dividido porque ha sido excluido de la cadena simbólica desde el momento en que es representado por ella. Es así que, la distinción entre enunciado y enunciación corresponde a "esa realidad del sujeto que ha sido alienada y reprimida en el proceso mismo por el cual, al recibir un nombre, es transformado en una representación de sí mismo" (28) lo que constituye un corte en la cadena significante que verifica la estructuración del sujeto como discontinuidad. Esta conceptualización del inconsciente como lenguaje se fundamenta en una operación primordial que Lacan realiza en su teoría y que consiste en retomar e invertir la fórmula saussureana. Si bien Lacan asume con

\footnotetext{
${ }^{25}$ Según Jameson, los sustantivos, en particular el Nombre del Padre, "despiertan al sujeto el sentido de una función [...] objetiva e independiente de la existencia del padre biológico" proporcionando una liberación del aquí y ahora de lo Imaginario "dado que la separación, por medio del lenguaje, entre la función paterna y el padre biológico es lo que permite al niño tomar [...] el lugar del padre" (28). Los pronombres, por su parte, son el lugar del surgimiento del inconsciente. "Para Lacan, éste es el significado de la barra que separa al significante del significado en el algoritmo semiótico: el pronombre [...] resulta en la división del sujeto, o Spaltung, que impulsa al "sujeto real" como si estuviera oculto, y deja en su lugar a un "representante" -el yo- (Ídem).
} 
Saussure el lenguaje como una estructura que se sustenta en elementos diferenciales y cuya vinculación entre las palabras y lo que ellas representan se produce de manera arbitraria, se distancia de él cuando propone que el significante tiene primacía sobre el significado en la creación del sentido. De esta manera, aunque el orden simbólico se presenta como un intento de sutura de la falla original no es tal en tanto el lenguaje se constituye no en función del significado sino del significante y estableciendo una cadena metonímica según la cual cada significante remite a otro y a otro y a otro $a d$ infinitud en virtud de que Lacan lo define como "lo que representa al sujeto para otro significante. Este significante será pues el significante por el cual todos los otros significantes representan al sujeto: es decir que a falta de este significante, todos los otros no representarían nada" (2005 [1966]: 799). En este proceso, el significado no se puede capturar porque responde al carácter esquivo y reprimido del deseo que no es sino este deslizamiento infinito del sujeto de significante en significante por el cual emerge, desde la plenitud imaginaria de la fase del espejo, como una estructura sometida a la supremacía del lenguaje ${ }^{26}$. La alteridad que resulta de este proceso de diferenciación tiene un efecto divisivo que se lo vive como castración, no sólo sexual sino también lingüística en tanto carecemos de comprensión plena del lenguaje y sólo podemos significarnos en un sistema simbólico

\footnotetext{
${ }^{26}$ En este punto, es importante señalar que una de las críticas que se le hacen al pensamiento lacaniano tiene que ver, precisamente, con esta función estructurante del lenguaje. Según Elliott "no se puede concebir el inconsciente por las diferencias intrínsecas a una estructura lingǘstica sino que se le debe entender como una organización significativa de formas de representación, de impulsos y de afectos" ya que la representación, siguiendo los escritos de Freud, es una energética obrante por la que los individuos organizan un conjunto de experiencias, por lo tanto, "esta capacidad de representación [...] es creadora en el más pleno sentido del término y no se la debe reducir a la lógica determinista de una "estructura"" (199-200). De esta manera, es posible afirmar con Elliott que en la obra de Lacan el sujeto es esencialmente pasivo en relación con el orden simbólico.
} 
que nos domina (Elliott 179) organizándose en dos polos lingüísticos que son, siguiendo la tesis de Roman Jakobson, la metáfora y la metonimia ${ }^{27}$. A partir de estas dos figuras, Lacan establece relaciones entre el psicoanálisis y la retórica que adquieren especial relevancia en el marco de la escritura de Severo Sarduy en tanto constituyen dos de los principales procedimientos de artificialización empleados en su escritura ${ }^{28}$.

En otra instancia, esta represión primaria que constituye la adquisición del lenguaje es reinterpretada en términos de la situación comunicativa como un todo en el cual se verifica la aparición de la mediación de otras personas, en particular del Otro (A), principalmente los

27 También Roman Jakobson tuvo una presencia notable para el grupo Tel Quel, principalmente en el período comprendido entre los años 1966 y 1970, en el proceso que tuvo como consecuencia una paulatina desontologización de la literatura. De éste tomaron tres cuestiones fundamentales: en primer lugar, el reconocimiento de la presencia de la función poética en discursos diferentes de los literarios tales como el político, el publicitario, el periodístico, etc. En segundo lugar, adoptaron la tesis según la cual la función poética tiene la particularidad de proyectar el eje de la selección (el paradigma) sobre el eje de la combinación (sintagma) por lo que, según la interpretación que los telquelistas hicieron de esta tesis, el texto permite que el paradigma se presente en el sintagma e irrumpa en el texto actual como antetexto. Esta manera de interpretar la tesis de Jakobson permitió a los telquelistas pasar de una concepción esteticista de la reflexividad a una concepción epistemológica por la cual la reflexividad se convierte en un acto de conocimiento mediante el cual el lenguaje contempla su fundación y su surgimiento y, por lo mismo, se instituye en una crítica política de aquella primera reflexividad que tenía todo su énfasis en la mera puesta en evidencia del signo lingüístico. Por último, el telquelismo tomó y transformó la concepción estructuralista del análisis de los textos literarios (Asensi Pérez 350-3).

${ }^{28}$ En "La instancia de la letra" (1966) Lacan articula la pregunta por el ser con la metáfora y la metonimia a las que relaciona con dos aspectos, en apariencias, contrarios, que son el síntoma y la carencia. La metáfora, cuya estructura indica que la sustitución del significante por el significante produce un efecto de significación "de advenimiento de la significación" (2007: 482) adopta el valor de respuesta frente a la pregunta por el "ser" en las asociaciones por semejanza en tanto "Brota entre dos significantes de los cuales uno se ha sustituido al otro tomando su lugar en la cadena significante, mientras el significante oculto sigue presente por su conexión (metonímica) con el resto de la cadena" (474) y, de este modo, determina el síntoma.

La estructura metonímica, por su parte, indica que la conexión del significante con el significante permite la elisión — del objeto, del referente- por la cual el significante instala la carencia de ser en relación de objeto (482) y funda la transformación del ser del sujeto en falta de ser (Balmes 2002: 136).

Es de notar que la relación entre la metáfora y metonimia y las asociaciones por contigüidad se corresponden con la condensación y el desplazamiento freudianos.

En el capítulo II el tema será retomado en relación con los procedimientos de artificialización de la escritura sarduyana. 
padres, e implica una nueva dimensión de esa alienación primaria del sujeto por el lenguaje. El Otro de la primera dependencia es la madre en tanto función que habilita el encuentro del sujeto con el significante que ella encarna. La función del Otro, en tal caso, es determinar la posición del sujeto ya que no es un interlocutor sino una alteridad radical no personal, el lugar evocado en el recurso de la palabra. Se puede establecer, entonces, que la función de la comunicación es un resultado del encuentro con el Otro por lo que, si bien es éste un término ambiguo, en todas sus acepciones introduce el significado de una falta o hiancia que incapacita al sujeto para ser plenitud. El Otro es el espacio de superposición entre la concepción de la lengua como estructura y la concepción de la lengua como comunicación ya que constituye simultáneamente "la dramatis personae de la situación edípica (pero más particularmente, el padre o sus sustitutos) y la propia estructura del lenguaje articulado" (Jameson 1995: 29).

También con este carácter eminentemente lingüístico de la teoría lacaniana se relaciona la cuestión de la sexualidad en el psicoanálisis. Según Jameson, la conexión entre ambas problemáticas debe realizarse a partir de la distinción entre necesidad, en tanto fenómeno biológico puro, y la demanda como relación interpersonal que sólo puede surgir después del lenguaje. En este sentido, se puede entender el deseo sexual como un campo cualitativamente nuevo y más complejo que se abre en el proceso de maduración a partir del cual un instinto previamente biológico experimenta una alienación en una relación fundamentalmente comunicacional para encontrar satisfacción (32). De este modo, la sexualidad constituye un punto intermedio entre la necesidad y la demanda no satisfaciendo a ninguna por 
lo que el deseo sexual es estructuralmente incapaz de una satisfacción final siendo el placer sólo una reducción momentánea de la tensión puramente física. Esto constituye una diferencia fundamental con el goce en tanto éste involucra la demanda de reconocimiento por el Otro que, por su propia naturaleza no sólo no puede ser satisfecha jamás, sino ni siquiera momentáneamente puede ser reducida la tensión. De aquí que Lacan, en el Seminario $X X$ (1972) afirme que el goce no es más que una instancia negativa porque "El goce es lo que no sirve para nada" (2006: 11); dicho de otra manera, no es la sexualidad ligada a la función reproductiva sino, por el contrario, puro derroche erótico.

Esta concepción del deseo como demanda protolingüística remite nuevamente al análisis retórico de los procesos psíquicos ya que, en tanto deslizamiento infinito del sujeto de significante en significante, el deseo es una función metonímica, mientras que el síntoma, como ya fue adelantado, un producto de la metáfora. Pero aún más, en lecturas sugestivas del nivel de las de Roland Barthes, la diferenciación placer/ goce permite establecer distinciones provechosas entre ciertos tipos de textos ${ }^{29}$. En El placer del texto (1973) señala esta diferencia afirmando que el texto de placer es el

\footnotetext{
${ }^{29}$ La relación de Barthes con Tel Quel se puede pensar a través de dos aristas. Por un lado, en 1963 Barthes publicó un conjunto de estudios que tenían por título Sur Racine y que fueron objetos de fuertes críticas por parte de Raymond Picard - de alguna manera, la voz de la institución universitaria en ese momento. La polémica que se suscitó a raíz de estas críticas tuvo como medio privilegiado, al menos para Barthes, la revista ya que los telquelistas no sólo publicaron todas sus respuestas a Picard sino que lo apoyaron explícitamente a través de la publicación de una serie de textos. Por otro lado, y más allá de estas razones coyunturales, Barthes encontró en los telquelistas en general y en Sollers en particular fundamentos y coincidencias con sus planteamientos críticos, prueba de lo cual es el análisis que le dedica a Drame, poco después de su publicación en 1965 (Asensi Pérez 2006: 73-75).

En relación con Sarduy, fue, probablemente, uno de los integrantes del grupo que más influencia ejerció sobre el escritor cubano aunque, es necesario aclarar, este vínculo se estableció como un mecanismo de retroalimentación en el que ambos autores se nutrieron de la obra del otro. Un ejemplo de esto es que Barthes tomó, en El placer del texto, como uno de los textos de goce funcionales a su análisis, a Cobra (1972), recientemente publicada.
} 
que: "contenta, colma, da euforia; proviene de la cultura, no rompe con ella y está ligado a una práctica confortable de la lectura" mientras que el texto de goce, por el contrario "pone en estado de pérdida, desacomoda, hace vacilar los fundamentos históricos, culturales, psicológicos del lector; la congruencia de sus gustos, de sus valores y de sus recuerdos, pone en crisis su relación con el lenguaje (1991: 25). Claro está que, entre ellos, no existe una diferencia de grados sino que, según Barthes, son fuerzas paralelas entre las que hay mucho más que un combate o una incomunicación ya que el texto de goce siempre surge como un escándalo que pone a la historia en conflicto y al sujeto en una contradicción permanente, "un sujeto dividido que goza simultáneamente a través del texto de la consistencia de su yo y de su caída" (35). Dicho de otra manera, el goce no surge en la destrucción sino en la ruptura, en la pérdida, en la fisura que se vuelven eróticas; ni en la cultura ni en su aniquilamiento sino en el límite, en la intermitencia, y exige una lectura de los dos bordes, de los intersticios, de la superposición de los niveles de significancia, una lectura que desmenuce el lenguaje en la enunciación y no en la continuación de los enunciados (23).

Frente al estereotipo, al que entiende como la figura por excelencia de la ideología”, el goce es lo nuevo, pero también la repetición, en tanto exceso: "La palabra puede ser erótica bajo dos condiciones opuestas, ambas excesivas: si es repetida hasta el cansancio o, por el contrario, si es inesperada" (68). Este derroche lingüístico que provoca el goce no sólo implica una provocación a la clase burguesa que "no posee ningún gusto por el lenguaje que a sus ojos no es siquiera lujo ni elemento de un arte de vivir [...] sino solamente instrumento o decoración" (63) sino también constituye, 
en mi opinión, un dispositivo de notable poder político en tanto es considerado por el mismo Barthes, como el único capaz de instalar la carencia de todo valor superior. Porque, si todo enunciado acabado corre el riesgo de ser ideológico (81) el texto de goce, que es un texto perverso, que se construye en pedazos — "El placer en pedazos; la lengua en pedazos; la cultura en pedazos" - es un texto que, en tanto no sea dicho, en tanto no sea convertido en dogma, está afuera de toda finalidad (83).

Esta preeminencia fundamental del lenguaje es un determinante, como ya lo vimos con Lacan, de las indagaciones sobre la noción del sujeto que se hicieron entre las décadas del sesenta y setenta y fundamentalmente entre los telquelistas y tuvo como una de sus consecuencias más notorias la postulación, común entre algunos de ellos, de lo que se dio en llamar la "muerte" o "la desaparición del sujeto". Claro que, es necesario aclarar, no se trata de un fenómeno surgido en este momento ni repentinamente sino de la continuación de un discurso filosófico que tiene sus antecedentes, por lo menos, en Friederich Nietzsche y su sentencia sobre "la muerte de Dios" por lo que, más que un cambio de paradigma desde el primado del sujeto al del lenguaje, constituye una transformación del posicionamiento respecto de esta categoría central de la Modernidad ${ }^{30}$. Esto significa que, como la muerte de Dios, también el sujeto tras su muerte dejó una huella que remite a él pero no como un esquema libre de contradicciones sino como un esquema quebrado en sí que exige reconocer como exagerada la confianza moderna en el poder del yo para apropiarse del mundo (Bürger 2001: 13).

\footnotetext{
${ }^{30}$ No sólo la crítica a la noción de sujeto unió a los telquelistas a la filosofía nietzscheana. También acordaron con la crítica a la oposición entre verdad y apariencia, la intencionalidad como fuente plana y unitaria de las acciones y el nihilismo (Asensi Pérez 2006: 240).
} 
En "La muerte del autor" (1968), escrito como es de notar unos años antes del Placer del texto pero ya en su etapa post-estructuralista, Barthes realiza un abordaje a la noción de autor que no sólo entronca sino que constituye uno de los aportes más reconocidos a la tan propugnada cuestión de su desestabilización ${ }^{31}$. Partiendo de la premisa de que el autor es una invención de la sociedad moderna creado en función del prestigio individual, Barthes critica las historias literarias en las que la presencia de éste adquiere la magnitud necesaria para explicar la obra por la vida aunque admite que algunos escritores, por ejemplo Mallarmé, ya han estado trabajando por su derrumbamiento y para, mediante la supresión del autor en beneficio de la escritura, devolverle un lugar al lector.

Pero es el campo de la lingüística, según Barthes, el que, fuera del ámbito específico de la literatura, más ha aportado a la destrucción del autor como tal en tanto demostró que la enunciación es un proceso vacío que funciona aún cuando no se lo complete con las personas de la interlocución: “el autor nunca es nada más que el que escribe, del mismo modo que yo no es otra cosa sino el que dice yo" (2002: 68$)^{32}$. Este alejamiento del autor transforma el texto moderno, principalmente en lo que hace al tiempo ya que, a partir de él sólo se concibe el tiempo de la enunciación, que es un eterno aquí y ahora, en oposición al tiempo lineal que supone la existencia

\footnotetext{
31 Seán Burke señala con precisión que la noción de "muerte del autor" que propone Barthes en 1968 sería de alguna manera rebatida por el mismo autor tres años después cuando, en 1971, publicó el trabajo Sade, Fourier, Loyola en el cual propone un regreso a esta noción (1998: 29).

${ }^{32}$ Recordemos que en 1966 Benveniste publicó Problemas de Lingüística General en el que "yo" como el que "representa la instancia discursiva que permite a un individuo enunciar la instancia de discurso que contiene la instancia discursiva "yo"" por lo que se puede concluir que no existe, según esta teoría, una identidad anterior sino que el lenguaje tiene el poder de poner al sujeto (Asensi Pérez 425).
} 
previa del autor respecto de su libro. Así se traza un campo que no tiene más origen que el lenguaje mismo porque se construye como un tejido de citas provenientes de "los mil focos de la cultura" (69) por lo que la función del autor se limita a imitar un gesto que es siempre anterior, nunca original. De esta manera, la escritura se vuelve múltiple, "instaura sentido sin cesar, pero siempre acaba por evaporarlo" (70) y, por lo mismo, se vuelve imposible el acto de su desciframiento. La literatura se vuelve revolucionaria porque "rehusar la detención del sentido, es, en definitiva, rechazar a Dios y a sus hipóstasis, la razón, la ciencia, la ley" (70). El lector, hombre sin historia, sin biografía, sin psicología, es el lugar donde se recoge toda esta multiplicidad, donde se mantienen unidas todas las huellas que constituyen el escrito. La metáfora de "la muerte del autor" refiere al precio que se debe pagar por el nacimiento del lector que deja de ser mero consumidor y se transforma en productor de una lectura que, aunque la recolectora de esas huellas, dispersa, disemina todo sentido reconociendo que "no hay verdad objetiva o subjetiva de la lectura, sino tan solo una verdad lúdica" (2002 [1970]: 37). Esta noción de lector se adelanta, entonces, a otras nociones estrechamente vinculadas como las de texto escribiblel texto legible trabajadas en $S / Z$ (1970) y texto de gocel texto de placer de El placer del texto $(1973)^{33}$.

Michel Foucault fue uno más entre los integrantes del grupo $\mathrm{Tel}$ Quel que teorizó sobre la "desaparición del autor". En Las palabras y las cosas. Una arqueología de las ciencias humanas (1966) se propone analizar

\footnotetext{
${ }^{33}$ El texto escribible es, precisamente, el que hace del lector un productor y no un mero consumidor del texto. Por el contrario, el texto legible es un producto que puede ser leído pero no escrito. La gran diferencia entre ambos está dada por la operación de la interpretación en tanto consiste no en darle un sentido al texto sino en apreciar la pluralidad que lo conforma (Barthes 1970b: 2-3).
} 
el campo epistemológico - la episteme- en el que los conocimientos manifiestan la historia de su condición de posibilidad, por lo que pretende que su análisis, más que una historia sea una investigación arqueológica que dé cuenta de dos grandes discontinuidades en la cultura occidental: la episteme que inaugura la época clásica (hacia mediados del siglo XVII) y la episteme de la época moderna, desde principios del XIX en adelante (1982: 7). El análisis de Las Meninas de Veláquez (1656), es el corpus del cual parte a fin de explicar algunas de las características principales de la episteme clásica que se estaban empezando a configurar. Esto es, por un lado, la separación entre "las palabras y las cosas" que se empezó a gestar desde que la interrogación estuvo puesta en la ligazón entre el signo y lo que éste significa, a la cual los clásicos responden en términos de representación y los modernos de significación (50). Las Meninas no hubiera sido posible sin esta primera condición en tanto constituye uno de los ejemplos quizás más paradigmáticos — junto al Quijote, en literatura, también trabajado en esta obra— de la otra característica propia de este momento que es la "representación de la representación". Esta puesta en escena del lenguaje señala con énfasis un vacío esencial que es el del que fundamenta esta representación (25). Si el sujeto fue suprimido durante la episteme clásica, aludido por la dispersión de signos que empezaban a organizarse bajo la lógica binaria que instauró el principio de identidad y diferencias, el resurgimiento del lenguaje en el siglo XX significa, para Foucault, una oportunidad en la que es indispensable volver a pensar la muerte de este sujeto ya que, si el hombre no es el problema más antiguo ni más constante del pensamiento humano sino que es una invención que muestra la 
arqueología del pensamiento, entonces, es dable pensar que "si esas disposiciones desaparecieran [...] entonces podría apostarse a que el hombre se borraría, como en los límites del mar un rostro de arena" (375).

Tan importante como las de Barthes, Lacan o Foucault, la presencia de Jacques Derrida en el espacio Tel Quel estuvo marcada también por la preocupación puesta en la problemática del signo, lo que despertó un interés mutuo con los demás telquelistas al punto de que un texto fundamental como La diseminación (1969) estuvo inspirado en la novela Nombres (1968) de Philippe Sollers, además de haber suscitado la atracción del mismo Sollers por uno de sus textos anteriores, L'Origine de la géométrie (1962), y de haber participado en el volumen conjunto que el grupo publicó en 1968, Théorie d'ensemble. Así, si la historia indica que lo que se conoció como la teoría de la deconstrucción fue atribuida casi exclusivamente a Derrida, la realidad es que surgió como producto de un ejercicio eminentemente telquelista que se caracterizó por esta vinculación directa entre la teoría y la práctica de la escritura —a la manera de El placer del texto de Barthes y Cobra de Sarduy- y que también lo tuvo como protagonista, en este caso particular, a Sollers y sus obras novelísticas ${ }^{34}$. En uno de sus primeros textos, De la grammatologie (1967), Derrida sienta las bases fundamentales de su teoría afirmando que "La historia de la metafísica [...] asignó siempre al logos el origen de la verdad en general (1998: 7) dejando a la escritura el lugar secundario e instrumental de fármaco

\footnotetext{
${ }^{34}$ Esta vinculación estrecha entre teoría y práctica de escritura y, en este caso, entre Derrida y Sollers le ha permitido afirmar a Manuel Asensi Pérez que "atribuirle el padrinazgo de la deconstrucción a Derrida es hacerle un flaco favor a la historia del pensamiento" ya que fue Sollers quien "“"primero" formuló las tesis acerca de la relación entre deconstrucción y literatura, el "primero" que las puso en circulación comprendió, entre otras cosas, porque él mismo estaba haciendo desde otro lugar, la "literatura"” (2006: 126).
} 
(Platón), símbolo de la palabra (Aristóteles), suplemento añadido a la voz (Rousseau), imagen y representación del sistema de la lengua (Saussure), intérprete de un habla originaria (13). Por esto, considera que todas las determinaciones metafísicas de la verdad son instancias inseparables del logos o de una razón pensada bajo su descendencia en tanto logos que nunca ha roto su vinculación originaria y esencial con la phoné, razón por la cual, la phoné constituye el significante original de una cosa o un estado (por ejemplo, el estado del alma en Aristóteles) mientras que la escritura no es más que su símbolo, la fijación de "convenciones que ligan entre sí otras convenciones" (17). Esta diferenciación instituye el origen de la noción de signo, en tanto implica la distinción entre significante y significado, que permanece en la descendencia del logocentrismo que es, también, un fonocentrismo (18). La deconstrucción, por lo tanto, — tal es el término que utiliza en este trabajo-, consiste en poner en evidencia este lugar secundario de la escritura y establecer los fundamentos de una nueva ciencia que permita desde dentro mismo de las estructuras de la filosofía "Habitándolas de una determinada manera [...] extrayendo de la antigua estructura todos los recursos estratégicos y económicos de la subversión" (32) — desbordar, transponer el orden del saber absoluto impuesto por el logocentrismo pero sin invertir las oposiciones binarias, con lo cual se establecería un nuevo centro absoluto, sino quedándose en el límite del discurso filosófico para desnudar la genealogía de los conceptos, desplazar su sentido, reinscribirlos en otras cadenas de sentidos: "Volver enigmático todo lo que cree entenderse bajo los nombres de proximidad, inmediatez, presencia” (91). Así ubicada en el campo de la filosofía trascendental, la 
deconstrucción no constituye un método de crítica literaria aunque sus reflexiones teóricas se traducen, tal como lo adelanté, en prácticas de escrituras concretas que se sustentan en la reflexión teórica sobre la escritura misma y cuyas nociones más importantes son las de, diseminación, archiescritura, huella y, particularmente, différance.

Abordada en trabajos como "La différance" (1968) o La diseminación (1969) esta cadena de "indecidibles" hace de la deconstrucción un concepto amplio que apunta a inquietar la tradición metafísica en tanto pone a la diferencia en el lugar de origen de todo sentido y propone el término différance — participio presente del verbo diferir, escrito con a y no con e por lo que tiene la particularidad de no pertenecer ni a la voz ni a la escritura - como concepto irreductible con un doble sentido: el de ser distinto y el de ser diferido. Dicho de otro modo, si el signo se coloca en el lugar de la cosa misma representando de esta manera al presente en su ausencia, el signo es entonces presencia diferida ya que su circulación difiere el momento en que podríamos encontrar a la cosa. En este sentido, la différance atiende a la temporización que implica interponer "la mediación temporal o temporizadora de un desvío que suspende el cumplimiento del "deseo" o de la "voluntad" efectuándolo de una manera que tanto puede anular como temperar el efecto" (1971 [1968]: 55) por lo que no existe originalmente una identidad, ni un ser pleno y homogéneo, ni ideas $\mathrm{y}$ sonidos preexistentes al sistema lingüístico, sino solamente diferencias que se inscriben en una cadena según la cual un concepto remite a otro y así infinitamente...diseminación: "Inventar el signo para ese "estar haciendo", para un movimiento a la vez ininterrumpido y quebrado, una 
continuidad de rupturas que, sin embargo no se allanará a la superficie de un presente homogéneo y evidente" (1997 [1969]: 463). En tal sentido, la différance es este movimiento que permite que la significación sea posible cuando cada elemento llamado "presente" se relacione con otra cosa que no sea él mismo mediante la inscripción de una traza o huella —señal del elemento pasado pero también, y en la misma medida, del futuroconstituyendo, de este modo, un intervalo —espaciamento-, que no es otra cosa que la conversión del tiempo en espacio, y que señala lo otro diferente fuera de lo mismo ${ }^{35}$. A esta escritura de la diferencia - archiescritura que es una protoescritura o escritura originaria, escritura de la huella- es necesario pensarla antes de las oposiciones por lo que es el origen que no ha desaparecido sino que no ha sido constituido sino en un movimiento retroactivo (1998: 84); el presente no existe como presencia absoluta, es sólo y no más que traza de traza.

Fieles al espíritu que envolvió al grupo durante todo su desempeño, los abordajes a la problemática del sujeto en relación con el lenguaje desarrollados por los integrantes de Tel Quel fueron múltiples, complejos y, en no pocos casos, discordantes. En este sentido, considero que los trabajos de Julia Kristeva constituyen aportes de relevancia que no escapan a la preocupación general del grupo pero sí adoptan particularidades que, entiendo, es necesario reseñar.

\footnotetext{
${ }^{35}$ En el mismo trabajo, Derrida establece relaciones de estos dos aspectos de la différance con las teorías freudianas en tanto entiende el diferir como discernibilidad, distinción, apartamiento, diasistema como espaciamento y como desvío, retraso, reserva: la temporización. En este sentido, el concepto de trazo, "abrir camino", inseparable del concepto de diferencia es también inseparable del origen de la memoria y el psiquismo como memoria.
} 
La vinculación de Julia Kristeva con París, primero, y con Tel Quel después se remonta al año 1965. Su llegada constituye un hito fundamental en la creación y consolidación de este grupo con el que se relacionó no sólo desde lo académico profesional sino también en lo personal —su boda con Sollers- y al que aportó un invalorable enriquecimiento intelectual. Por un lado, Kristeva incorporó definitivamente la teoría lingüística y literaria eslava. En 1966 fue invitada por Barthes a dictar una conferencia en uno de sus seminarios. Allí aprovechó para introducir la figura de Bajtín y seducir a sus interlocutores con la precisión de su lenguaje teórico y el dominio de los conceptos que le permitían condensar la tradición de la lingüística y la semiótica soviéticas (Asensi Pérez 94). Por otra parte, utilizando las distintas ramas del saber que ostentaba -lingüístico, semiótico, psicoanalítico y marxista-leninista-ejerció un papel creativo por el que modificó y transformó una larga lista de conceptos dando, de este modo, un impulso fundamental a lo que ya constituía una característica del espacio Tel Quel (76).

$\mathrm{Si}$, como hemos visto, algunas de las tesis más fuertes sobre la problemática del sujeto producidas por el grupo desde mediados hasta finales de la década del sesenta apuntaban a señalar su desaparición, es necesario advertir que, aunque en su momento las había defendido al menos parcialmente, en los trabajos realizados a partir de los primeros años de la década del '70, Kristeva, y conjuntamente Sollers, se muestra frontalmente opuesta a ellas ya que, sin tratar de recuperar el sujeto cartesiano lo que sí pretendió fue situarlo en una perspectiva materialista que se valiera, por 
ejemplo, de las herramientas del psicoanálisis $(164)^{36}$. Esto dio lugar a una preocupación que abrió paulatinamente las teorizaciones hacia el sujeto, el cuerpo y las diferencias sexuales que serían retomadas y ampliadas con renovado interés años más tarde por intelectuales de la talla de Judith Butler, entre muchos otros.

En la ponencia "El sujeto en proceso", presentada en el coloquio Cérisy-La-Salle a propósito de Bataille y Artaud, en 1972, Kristeva presenta y define una nueva noción de sujeto que denominó "sujeto en proceso" en la que defiende, como una de sus principales tesis la idea de que el sujeto no desaparece sino que se transforma a través de su cuerpo ${ }^{37}$. En efecto, parte de enunciar su propósito en el trabajo definiéndolo como una "tentativa intra-teórica de consecuencias ideológicas" con lo que apunta a invadir la neutralidad teórica positivista con la experiencia del sujeto —en este caso, el sujeto Artaud-de la teoría y por su capacidad de ponerse en proceso

\footnotetext{
${ }^{36}$ Este cambio en los planteamientos teóricos de Tel Quel estuvo estrechamente relacionado con los cambios a nivel socio-político que se iban produciendo desde comienzos de la década. Uno de ellos fue la desilusión generalizada con respecto al pensamiento y las políticas de izquierda - especialmente como consecuencia del fracaso del movimiento del 68- que tuvo como hecho decisivo, en este sentido, la publicación del libro $E l$ archipiélago Gulag de Alexander Soljenitsyn en 1973. Para Manuel Asensi Pérez es éste un período eminentemente post-político en tanto "no hay alternativa de gran política, de gran partido, de gran colectividad, de gran ideología, y la estrategia de Tel Quel empezará a buscar por la vía de la excepción, de la individualidad y de la subjetividad" (2006: 179) por lo que "el problema consiste en recuperar ese sujeto marginado, en lo cual la literatura cumple una función ética irremplazable" (180).

${ }^{37}$ En una etapa inmediatamente anterior a esta y, de alguna manera preparatoria, Kristeva teorizó sobre el "sujeto cerológico". Esta noción implica la representación de un lugar vacío en tanto lo que desaparece no es el sujeto en sí sino el sujeto racional, es decir, gobernado por la lógica que funda el orden simbólico. En tal sentido, Kristeva afirma: "no hay "sujeto" (y con ello no se puede hablar de insconsciente) más que en un pensamiento del signo que compense la pluralidad paralela de las prácticas semióticas ocultadas por la dominación del signo, dándose fenómenos "secundarios" o "marginales" (el sueño, la poesía, la locura), subordinados al signo" (1981 [1969]: 90). El sujeto no depende de ningún signo, aun cuando sea imposible pensarlo sino a través de él, por lo que su lugar es el polo opuesto del espacio lógico dominado por el sujeto hablante. La semiótica poética es "el espacio neurálgico de nuestra cultura donde se operan las junciones entre el pensamiento del signo en tanto que habla normativa, y ese funcionamiento que no precisa de un sujeto lógico para ejercerse" (90).
} 
para, volviendo al lugar de la metalengua, enunciar la lógica de ese proceso (1977 [1972]: 35). Una de las tesis que sostiene este propósito retoma las teorizaciones lacanianas sobre el sujeto, al cual denomina "sujeto unario", y señala que ponerlo en proceso es considerarlo sólo como un momento, excedido y amenazado por el movimiento, por lo cual el proceso no es una dinámica subañadida sino que rechaza la censura sobre la que se instaura el orden del sujeto y, por lo tanto, también el orden social que es la división Consciente/ Inconsciente, Significante/ Significado. El proceso disuelve el signo lingüístico y su sistema sobre el que se sustenta el sujeto unario y pone en libertad las pulsiones que la función simbólica reprime para constituirse en materia biológica y social a-simbolizada (37). En contraposición a lo simbólico opera la noción de lo semiótico que, según Kristeva, constituye el lenguaje poético en el que elementos significativos del lenguaje no representan ni significan algo sino que permiten a estas pulsiones este proceso de escape del orden simbólico. Dicho de otro modo, lo semiótico representa el lugar donde se concentran las pulsiones libidinales prelingüísticas, es el "lugar móvil-receptáculo del proceso" [Itálicas en el original] que denomina chora [Itálicas en el original], lugar que será reprimido por el signo y del cual sólo el deseo quedará como testigo (2006 [1980]: 23). Las estructuras lingüísticas, entonces, funcionan como bloqueos del proceso al que captan e inmovilizan subordinándolo bajo unidades significantes e institucionales que se efectúan por medio de los aparatos sociales pero también por medio de la estructura significante ${ }^{38}$.

\footnotetext{
${ }^{38}$ En relación con esto, Kristeva establece una diferenciación fundamental entre el sujeto unario de Lacan y el sujeto en proceso que propone la práctica de escritura de Artaud en función de la negación y la negatividad. Para Kristeva, mientras que la negación simbólica es una función sintáctica en tanto es la función simbólica que plantea el sujeto unario -el
} 
El proceso funciona a través de la separación, de la reiteración de la ruptura que repele la discordancia entre significante y significado y el aislamiento del sujeto como significante por lo que es la renovación hasta el infinito de su propio funcionamiento (38). Esta noción de sujeto no se propone entonces, la "muerte del sujeto" o su desaparición sino una dinámica que le permite al sujeto salirse del encierro del lenguaje con una voluntad revolucionaria que sólo así puede dar lugar a una nueva subjetividad y una nueva corporalidad (Asensi Pérez 457): “A-subjetivo, el proceso puesto en marcha y renovado por el rechazo es a-familiar, a-filial, a-social. Únicamente los movimientos de subversión social, en períodos de mutación o revolución, pueden dar un campo de acción social a este proceso de rechazos" (Kristeva 1977 [1972]: 38).

En este planteo, la función que le corresponde al arte, especialmente a la vanguardia literaria — recordemos que Kristeva está presentando su ponencia en torno al trabajo de Artaud - es la de hacer una revolución que sea distinta a la revolución socialista o comunista presentando a la sociedad un sujeto en proceso que ataque cualquier posible inmovilidad del proceso unario, a los sistemas ideológicos cerrados y a toda estructura de dominación social; es decir, una revolución que se plantee no como una utopía de las demás sino, mediante este proceso esquizofrénico de la vanguardia artística, muestre su ceguera respecto del proceso que la comporta e introduzca una nueva historicidad (42).

Nombre del Padre lacaniano_ - la "negación auténtica" implica una desaparición del sujeto unario - perdido en tanto unario porque se ha multiplicado- que rechaza la filiación, un pensamiento impersonal que constituye la única destrucción posible del pensamiento sin que se pierda el proceso de significancia: "La negatividad es el rechazo que el sujeto reprime al decir "No", y que vuelve para agredir contra ese "No": contra el Nombre del Padre, contra el super-yo, contra el lenguaje mismo y el rechazo originario mediante el que se impone" (1977 [1972]: 46) 
En tal sentido, creo que esta propuesta de Kristeva explica, aunque no en la validez de los argumentos sino en la paradoja que esto conlleva, la censura ejercida sobre ella y el grupo Tel Quel desde las autoridades culturales del gobierno cubano, a partir de los últimos años de la década del sesenta y primeros de la del setenta, como parte de la política de radicalización que tomó forma oficial en el Primer Congreso de Educación y Cultura (1971) y que tenía como uno de sus objetivos fundamentales transformar el realismo socialista, en su versión soviética más dogmática, en política oficial (Navarro 1997: X). Sin embargo, creo que es importante notar que, aunque la relación de los telquelistas con el marxismo contempló posiciones tan dispares como la lectura estructuralista de Marx realizada por Althusser o las posiciones no marxistas de Foucault, entre muchas otras variantes, esta vinculación controvertida del grupo Tel Quel con los partidos de izquierda —en concreto, el Partido Comunista Francés-, si bien se manifestó abiertamente en este momento, había comenzado unos años antes — hacia mediados de la década del sesenta - cuando en honor a su espíritu ecléctico, Tel Quel aprovechó su acercamiento al PCF como un modo no dogmático de difusión y a pesar de que las relaciones entre ellos no se presentaran exentas de suspicacias. Así lo expresa Kristeva en su autobiografía: "Estado dentro del Estado, poseedor de un poder considerable de difusión y de propaganda distintos de los circuitos tradicionales saturados por las producciones más convencionales, ¿no era el PCF el mejor altavoz para un trabajo literario y teórico esencialmente de laboratorio?" (citado y traducido por Asensi Pérez 112). 


\section{Escrituras de la subjetividad}

\section{II.1. Gestos de un viaje sin retorno}

Los géneros en la literatura constituyen uno de los puntos de los que la crítica y la teoría se han ocupado con mayor profusión. Tanto es así que han sido abordados desde posturas tan variadas como disímiles incluyendo miradas que giran en torno a un estudio sistemático y clasificatorio de sus características estructurales así como otras que proclaman su inexistencia en tanto tales.

Es así como, por un lado, los géneros han sido comparados con un organismo biológico y por eso clasificados en función de su "naturaleza" susceptible de ser claramente percibida por el agudo ojo del observador. Esta forma de clasificación nos remite a Aristóteles, quien elaboró un marco filosófico para el ordenamiento de todo lo existente según el cual el mundo se organiza naturalmente en divisiones, siendo la labor del sabio articularlas lingüísticamente de un modo sistemático. Esto representa una fundamentación metafísica y epistemológica para quienes sólo pretenden clasificar los géneros ya que si todo lo que existe pertenece a alguna clase natural que puede ser captada intuitivamente por medio de la observación y la inducción, determinar estas clases supone observar un número suficiente de individuos y captar y articular sus rasgos comunes (Rollin 1988: 133).

Para Jean Marie Schaeffer este modelo de pensamiento está en total desacuerdo con la fenomenalidad propia del texto en tanto que dimensión lingüística la que "que nunca es la de un sistema cerrado, sino más bien la 
de una cadena abierta" (1988: 166). A esta objeción se le puede añadir otra: la de que esta concepción orgánica implica aceptar que en un determinado momento una estructura determinada llegue al máximo de su rendimiento y se transforme, de esta manera, en modelo y molde a imitar (Garrido Gallardo 1988: 11). Las consecuencias no son difíciles de prever: apuntan a un proceso de clasificación y homogeneización de los textos que trae aparejado, por un lado, la simplificación extrema de una problemática compleja y profundamente enriquecedora de los estudios literarios, por el otro lado, la exclusión y el olvido, precisamente, de aquellos textos que se resisten a ser encasillados en un molde cerrado. Tal como afirma Alastair Fowler "de los muchos factores que determinan nuestro canon literario, el género se encuentra sin duda entre los más decisivos" ya que no sólo algunos se consideran más canónicos que otros sino que las mismas obras pueden ser estimadas en mayor o menor medida de acuerdo con la categoría de género a la que pertenezcan (1988: 100).

Por el otro lado, cuando este modelo naturalista fracasó como soporte metafísico de clasificación, el cambio implicó la postura extrema: el género como pura convención y artificio. Según esta perspectiva, los géneros son reglas hechas por nosotros en momentos específicos, susceptibles de cambio y sustitución; es decir, convenciones que crean sus propios casos, codificados de la manera que las cosas deberían ser y no como las cosas son tal como se piensa en el modelo naturalista; normas artificiales y prescripciones para el terreno literario, no descripciones esenciales de su naturaleza intrínseca (Rollin 1988: 139). 
En este orden de cosas, según Schaeffer, entender la construcción de los géneros como un proceso puramente textual tiene una ventaja evidente que reside en que ésta permite fijar un criterio empírico para definir la genericidad en contraposición con las teorías ontológicas en cuyo caso, como hemos visto ya, los géneros son por definición, trascendentales a la textualidad y por ello mismo, empíricamente inabordables (1988: 162).

De esta manera, la teoría del género se ha visto sumida en un movimiento constante basado en el dualismo naturaleza- convención entre nomos y physis - que ha permanecido virtualmente indiscutido desde los presocráticos hasta nuestros días (Rollin 142) y que nos ha obligado a los críticos a adoptar posturas extremas por las que desechamos, en más de una oportunidad, este abordaje como una perspectiva probable para nuestros análisis. En este sentido, concuerdo con Rollin cuando afirma que "el escepticismo total acerca de las clases literarias es infundado pero, por otro lado, también lo es el intento de realizar una lectura directa de estas clases a partir de la naturaleza" (148).

Creo, entonces, que el problema de los géneros nos pone en la obligación de repensarlos en un pretendido equilibrio ganado a través de la consideración responsable y crítica de los sistemas de caracterización y clasificación de los que disponemos en relación con los elementos del contexto literario más pertinentes al caso, sean estos la obra en cuestión, las genealogías que construye, las obras con las cuales dialoga, etc.

La controversia en que se encuentra inmersa la crítica literaria de los últimos tiempos con respecto al tema de los géneros se corresponde con la práctica escrituraria específica del campo de la literatura en particular y de 
la práctica cultural y artística en términos generales. Si bien es cierto que la transgresión de los límites genéricos es un ejercicio que se remonta a expresiones muy tempranas, también es verdad que desde mediados del siglo XX en adelante este recurso ha cobrado una importancia singular al punto de imponerse casi como una constante necesaria. Los géneros son "manifestación de las posibilidades creadoras del hombre, pero también de la temporalidad de todo quehacer humano" (Garrido Gallardo 1988: 21) y es en razón de esto que acuerdo con José Amícola en leerlos en función del plus de sentido que nos suministran, es decir, no como moldes vacíos y ahistóricos sino como un "territorio de fricción de sentidos [...] un lugar altamente productivo para el desarrollo de la crítica cultural" (2003: 53). Es decir, como lo plantea Jesús Martín-Barbero en su análisis sobre el folletín, el género pensado como "clave de lectura, de desciframiento del sentido y en cuanto reencuentro con un "mundo"” (2003: 200)

A la luz de esta premisa, releer la obra narrativa de Severo Sarduy teniendo en cuenta la problemática de los géneros es una perspectiva que abre un campo de análisis que amplía y enriquece los aportes que hasta ahora se han venido realizando los cuales han sido, en mi opinión, aunque no muy abundantes sí variados y, hasta cierto punto, discrepantes entre sí. Así, por ejemplo, si en la mayoría de las ocasiones Cobra (1972) ha sido estudiada poniendo el énfasis en la dificultad de su lectura a raíz de los procedimientos discursivos utilizados, las últimas tres novelas -Colibrí (1984), Cocuyo (1990) y Pájaros de la playa (1993)—, por el contrario, han sido abordadas en función de sus, aparentemente más simples, tramas narrativas y, bajo esta premisa, encorsetadas dentro de categorías genéticas 
rígidas en las cuales no siempre estas obras encajan ${ }^{39}$. Me propongo, entonces, revisar algunos de estos abordajes, con el objetivo de retomar aquellos aspectos que considero acertados y reformular o proponer nuevas lecturas posibles. El orden en el que he abordado las novelas - Gestos (1963), De donde son los cantantes (1967), Cobra (1972) y Cocuyo (1990)— no sólo tiene cierta ordenación cronológica sino también y, en mi opinión como consecuencia de esto, una lógica que rige la estructura genérica de las obras en torno a una propuesta en la que la primera y la última están marcadas por una aparente y relativa sujeción a ciertas formas y modelos frente a las rupturas y fragmentaciones extremas de Cobra y no tan extremas pero sí de gran importancia en De donde son los cantantes que alejan las obras de cualquier encasillamiento genérico posible.

\footnotetext{
${ }^{39}$ Un ejemplo de esto es el trabajo de Julia Kushigian "Severo Sarduy, orientalista posmodernista en camino hacia la autorrealización. Une ménagerie à trois: Cobra, Colibrí y Cocuyo" en el que la autora analiza las tres obras mencionadas, a las que considera "tres textos orientalistas", como pertenecientes al subgénero Bildungsroman en el que la idea central está relacionada con la autorrealización del personaje principal (1999: 1606). Intentaré demostrar a lo largo del capítulo que este es un encasillamiento que no se puede sostener en ninguna de las tres obras sarduyanas.
} 


\section{II.1.1. El viaje}

Habrá que cambiarlo todo, que virar la vida boca abajo y luego salir de pronto a la calle, a cualquier esquina e ir sorprendiendo a cada uno que pase para sacudirlo por los hombros y gritarle oiga mire coño oiga mire coño hay que virar la vida al revés.

Severo Sarduy, Gestos (1963)

La metáfora del viaje constituye, quizás, uno de los tópicos más recurrentes y clásicos de la literatura. En torno de ella se estructuran géneros y subgéneros de distinta índole como la novela de aprendizaje o la épica y, en materia de literatura latinoamericana, lo que podría considerarse como una variación temática de la primera, la novela de la selva. Forma parte de un universo simbólico en el que el desplazamiento en el tiempo y el espacio es, en la mayoría de los casos, un generador de crecimiento personal o social en tanto los sujetos involucrados en esta experiencia culminan su trayectoria modificados en algún sentido que los hace "mejores": personas, artistas o miembros de una comunidad ${ }^{40}$. Las transformaciones que sufre el personaje tienen una significación fundamental en este esquema pero no lo son menos los acontecimientos ya que, a través de ellos y de la manera como son enlazados, se produce el avance necesario para que el destino final del héroe

\footnotetext{
${ }^{40}$ El viaje, según Beatriz Colombi, presenta una enorme dificultad para ser definido y caracterizado por lo que, en su trabajo Viaje intelectual. Migraciones y desplazamientos en América Latina (1880-1915), reseña diferentes abordajes en torno a este problema, entre los que se encuentran autores como Edward Said, Germanie Bree, Percy Adams, Mary Louise Pratt, etc. Una de las aproximaciones que más conviene a este trabajo, en mi opinión, es la que Colombi cita y traduce de James Clifford: "El viaje es un término inclusivo que abarca un amplio rango de prácticas, más o menos voluntarias, de dejar la "casa" para ir a "otro" lugar. Este desplazamiento tiene el propósito de una ganancia - material, espiritual o científica- e involucra la obtención de un conocimiento o la vivencia de una experiencia (excitante, edificante, placentera, expansiva, de extrañamiento)" (2004: 22-3).
} 
sea un lugar - físico y simbólico - que realmente esté más allá del punto de partida. Una de las claves de esta progresión está puesta en la constitución psicológica y caracterológica del héroe; las demás, en la representación lineal del tiempo y el espacio. El resultado de estos procedimientos discursivos es la construcción de una narrativa que cuenta una Historia trascendental y organizada cuyo personaje es un Héroe masculino, coherente y representativo de una colectividad a quien le debe, pero también a quien le otorga, una identidad homogénea.

Ligado de este modo al contexto de los relatos de formación de las naciones, el tópico del viaje en América Latina puede encontrarse, más o menos explícitamente, en múltiples expresiones literarias que abarcan, desde las ficciones fundacionales propias del siglo XIX a la novela de la tierra de principio del XX y hasta algunos ejemplos, no menores, de la novelística del "Boom" como sería, en el caso cubano, Los pasos perdidos (1953) de Alejo Carpentier.

En el artículo "Modelos épicos para la novela de la Revolución cubana" (1984) Seymour Menton analiza y esquematiza algunas obras que considera representativas de la Revolución en función de un modelo que él mismo diseña y que permite clasificar a las novelas escritas por cubanos y con temática revolucionaria en los años inmediatos posteriores a 1959. Dicho modelo actualiza las categorías de épica muralista y épica heroica a las que caracteriza según adopten un enfoque macro o microcósmico, respectivamente, y para las cuales toma algunos ejemplos de la literatura universal que le sirven de parámetros para su clasificación. Menton define a la categoría de épica heroica, en la cual incluye a Gestos, como aquella 
expresión literaria que "se ocupa de las hazañas militares extraordinarias de un superhéroe apoyado por un grupo relativamente pequeño de amigos leales, en un período histórico de gran significación nacional" aunque lo que realmente otorga la índole épica al conflicto es el hecho de que la obra sobrepase las dimensiones del realismo y revele una conciencia de la perspectiva histórica (1984: 343). Los modelos a tener en cuenta son, en este caso, obras de la talla de la Ilíada (siglo VIII a. C), la Chanson de Roland (siglo XI), el Poema del Mío Cid (siglo XII) y Los de abajo (1916) de Mariano Azuela.

Para incluir a Gestos dentro de la épica heroica, Menton se basa en una serie de rasgos como la utilización del estilo de la lengua oral, la predominancia del presente con una importante perspectiva histórica y el empleo de algunas técnicas cinematográficas como las tomas en zoom y el panning que, según el autor, permiten "sobrepasar" el realismo (347-8). Sin embargo, considero que entender Gestos como épica heroica en razón de estas características constituye un análisis con pocos fundamentos no sólo porque hay en esta novela una innumerable cantidad de procedimientos discursivos que no han sido tenidos en cuenta sino también porque aún los que sí se consideraron fueron tomados desde una perspectiva que no profundiza en los pliegues y reveses de la escritura sarduyana ${ }^{41}$.

Gestos (1963) es la primera novela de Sarduy. En ella se presenta una visión de La Habana de los '50 — común a los cuentos y novelas de la

\footnotetext{
${ }^{41}$ En este sentido, son paradigmáticos dos trabajos en los que los mismos procedimientos discursivos son atribuidos a distintas manifestaciones literarias. Por ejemplo la oralidad ha sido tomadas por Andrew Bush (1984) como anticipación del barroquismo que luego se verá desarrollado con esplendor en obras posteriores del mismo Sarduy como Cobra. Iván Schulman, por su parte, analiza el empleo de técnicas cinematográficas como ejemplos de los procedimientos propios del nouveau roman de Robbe- Grillet, entre otros (1966).
} 
primera década de la Revolución — en la que predominan la frivolidad y los valores de la sociedad de consumo (González Echevarría 1987: 79). En Gestos se cuenta el deambular cotidiano, durante unos pocos días alrededor del año 1959, de una mujer cubana, de la que, es importante aclarar, nunca se da a conocer un nombre que permita identificarla plenamente. Ella es artista —ensaya una puesta en escena de Antígona-pero se gana la vida lavando ropa y se prepara para, hasta que finalmente lleva a cabo, concretar un atentado revolucionario -único acontecimiento relevante de la novelacontra una planta de energía eléctrica, como expresión de repudio contra el gobierno dictatorial de Batista. Esta triple posición de sujeto - artista, lavandera y revolucionaria-, sumada a la carencia de nombre propio, constituye uno de los primeros elementos y quizás más significativos que nos hacen dudar de que la primera novela del autor cubano sea, sin más, un ejemplo de la narrativa épico- heroica en tanto es evidente que no contamos en esta obra con la presencia de un héroe masculino, aguerrido, con metas claras e ideales inalterables que se desplace en el tiempo y el espacio buscando la manera de cumplirlas sino, por el contrario, se trata de una mujer para la que la actividad revolucionaria constituye un momento, una actividad más en su constante lucha por la vida. Pero más se complejiza este aspecto si tenemos en cuenta que no es ésta una lucha elegida o aceptada como una cuestión de honra y honor sino que lo asume como una obligación que las circunstancias históricas - pero también amorosas- le han puesto en su camino.

Por su parte, su condición de mulata es un elemento que se agrega a esta construcción "distorsionada" del héroe nacional en tanto, por un lado, 
no representa el mestizaje como metáfora de la constitución de una nueva cultura homogénea sino a la "mulatez" como un componente que se suma y hace sus propios aportes a la cultura cubana pero desde las tensiones que impone la heterogeneidad ${ }^{42}$. Por el otro, y no menos importante que el anterior, nos obliga a pensar en la construcción decimonónica de la mujer mulata como símbolo de erotismo y sensualidad (Kutzinski). Recordemos, en este sentido, la Cecilia de Cirilo Villaverde y su larga tradición de mulatas encantadoras de hombres blancos que, por su debilidad carnal, han

\footnotetext{
${ }^{42}$ Pienso en el concepto de heterogeneidad a partir de los trabajos de Antonio Cornejo Polar escritos en 1977 y retomados con vigor en uno de sus libros más reconocidos Escribir en el aire. Ensayo sobre la heterogeneidad socio-cultural en las literaturas andinas de 1994. En este libro, Cornejo Polar se propone reflexionar sobre cómo la búsqueda de la identidad en América Latina "dio lugar al desasosegado lamento o a la inquieta celebración de nuestra configuración diversa y múltiplemente conflictiva" (13) en tanto se dio un proceso por el cual la profundización en la problemática tuvo como resultado la evidencia de las contradicciones y realidades que constituyen América Latina. Con este propósito, Cornejo organiza su análisis en torno a tres núcleos problemáticos que son el sujeto, el discurso y la representación y emplea el concepto de heterogeneidad como herramienta de trabajo para abordar dichas nociones no sin antes recordar que, aunque inicialmente fue una categoría útil para dar cuenta de los procesos de producción de literaturas en las que se intersectan conflictivamente dos o más universos socio-culturales (16), más adelante comprendió que la heterogeneidad se infiltra en la configuración de cada una de esas instancias "haciéndolas dispersas, quebradizas, inestables, contradictorias y heteróclitas dentro de sus propios límites" (17). De este modo, Cornejo indaga la problemática de los ejes mencionados desde una perspectiva que intenta dar cuenta de los conflictos pero sin la intención de construir a partir de ellos categorías que los subsuman ni los homogenicen. Es así que propone, en cuanto al discurso, inquirir en la escisión producida entre la voz de las culturas ágrafas andinas y la letra de la institución literaria occidental leyendo los textos como espacios lingüísticos en los que "se complementan, solapan, intersectan o contienden discursos de muy varia procedencia, cada cual en busca de una hegemonía semántica que pocas veces se alcanza de manera definitiva" (17). Es por esto que los discursos en cuestión son portadores de tiempos y ritmos variados que los atraviesan y le otorgan densidad histórica. Con respecto al sujeto, de lo que se trata es de poner en cuestión la imagen romántica del yo que impone un sujeto suficientemente firme y coherente que, por más exaltado y mudable que sea, siempre puede regresar sobre sí mismo. Así, ante el problema del sujeto latinoamericano, la pregunta de rigor se formula en torno a la disyuntiva entre un modelo de identidad totalizadora y única y la propuesta de Cornejo de un sujeto que se configura en la inestabilidad de la intersección de muchas identidades disímiles, oscilantes y heteróclitas (21). La representación, finalmente, en cuanto construcción discursiva de lo real, se manifiesta mediante códigos de ruptura y fragmentación que expresan experiencias de vida signadas por el caos, la inquietud, la heterogeneidad.
} 
caído en la tentación y debieron pagar su pecado con el abandono, el desprecio y, finalmente, el incesto ${ }^{43}$.

Un ejemplo claro de esto son las descripciones de las costumbres y los ritos propios de cada una de las comunidades constituyentes de esta cultura. A diferencia de lo que hará en sus siguientes novelas, en Gestos Sarduy presenta una sociedad en la que la convivencia de los distintos elementos puede ser conflictiva a veces y pacífica en otros momentos pero siempre de una heterogeneidad de la que la escritura no puede dar cuenta precisa si no es mediante la representación individual de cada una de ellas: una representación en la que los lenguajes, las religiones, las diferencias coexisten y dialogan pero pertenecen a distintos sujetos, a distintas culturas y a distintos espacios de la estructura de la novela. Así, por ejemplo Sarduy describe el baile y el canto de los negros:

El canto de los negros de La Habana viaja seguro, a través de las bahías, hasta que llega a la de Manzanillo. [...] La música es arbitraria y la letra sin rima ni metro se va improvisando libremente

\footnotetext{
${ }^{43}$ En su primera versión Cecilia Valdés o la loma del ángel (1838) fue un cuento que sólo parecía tener pretensiones costumbristas pero su versión final, de 1881, fue una extensa y exhaustiva presentación novelada del problema de la esclavitud. En esta obra, Villaverde presentó todas las clases y tipos sociales y raciales que constituían la pirámide social colonial. En opinión de Cécile Leclercq la novela es "el mejor ejemplo literario de la racialización de las relaciones sociales en la Cuba colonial y esclavista" (2004: 415). Sin embargo, este no es el único mérito que se le reconoce a esta obra ya que otro trabajo importante que Villaverde llevó adelante en su novela fue la profundización en el mundo de los mulatos aunque, como es de esperar, a través de la mirada decimonónica de la división verticalizada de las clases según la raza. Si Villaverde se ocupa entonces de los mulatos es porque considera que son quienes mejor interiorizaron los valores de la clase dominante y su posición intermedia entre blancos y negros se manifiesta en deseos de ascenso social, principalmente por parte de las mujeres mulatas que buscan mejorar su situación uniéndose a hombres blancos. Estas mujeres, que son definidas como de "raza híbrida o mezclada", son de naturaleza frágil, poco virtuosas, sensuales, símbolos de la transgresión de los valores morales impuestos por el catolicismo.

Años después de su publicación, la novela comenzó a ser considerada como la "novela nacional cubana" porque en ella aparecían todos los elementos de la heterogeneidad cubana. En 1932 se estrenó una comedia lírica en un acto con música de Gonzalo Roig y libro de Agustín Rodríguez y José Sánchez-Arcilla lo que, según González Echevarría, contribuyó a la construcción de Cecilia Valdés como "mito literario nacional" (1999:1600). Desde mediados del siglo XX, Cecilia simbolizaría el mito de fusión racial, el mestizaje, uno de los estandartes ideológicos enarbolados por la Revolución de 1959 como signo de unidad nacional.
} 
a medida que los miembros del coro piden su turno para cantar. A veces dos o tres se reúnen en un estribillo o hay varios solistas que cantan sobre temas diferentes (Sarduy 1999 [1963]: 270-1).

Mientras que, unas cuántas páginas más adelante, describe elementos que considera representativos de la cultura china: "La llama central, el doble hexágono de cristales rojos, flecos de papel de China que terminan en un racimo de cascabeles. La farola ilumina lenguas bífidas de celofán agitadas por las tenazas del gran alacrán de madera negra" (291). Otros ejemplos en este sentido, pueden ser la inclusión de escenas propias del circo, el carnaval o el teatro griego, todos elementos de las distintas culturas que confluyen y conviven en el espacio de la cubana.

Finalmente, la construcción monológica del sujeto heroico también se ve amenazada por el uso de las voces enunciadoras. Si la épica se construye en torno a un narrador omnipresente, que dispone de autoridad absoluta para organizar y dirigir el relato, en Gestos la voz autorial del narrador en tercera persona es erosionada por el empleo de la técnica del monólogo interior que devela las dudas y contradicciones de la mujer y pone en entredicho, una vez más, su participación voluntaria y heroica en las acciones revolucionarias:

Ésta será la última. Las pastillas no resuelvan nada; mi dolor es tan grande que tendría que meterme una caja en la cabeza y eso debe provocar más dolor. Iré a decirles que está bueno ya, que no me dejan vivir, que no he podido aprenderme el papel para la obra. Pero cómo ir a un tiroteo con esta cabeza, con este dolor, con este pelo. ¿Quién afronta un tiroteo con esta cara? (326).

Por otra parte, pero en este mismo sentido, es necesario tener en cuenta la presencia del canto como otro elemento fundamental de los relatos épicos que en Gestos configura una problemática que se desvía de las gestas heroicas. Si es posible afirmar que en esta novela se produce un 
desplazamiento constante de los personajes, también se puede decir que este movimiento está acompañado continuamente por el canto, acorde, en cada caso, a la cultura de quien lo entona por lo cual, no se erige en representación de toda la comunidad sino como un componente más de diferenciación que permite vislumbrar la coexistencia de elementos heterogéneos y contradictorios. Cantan los negros, la mulata, los chinos pero también canta el autor, aunque no lo hace asumiendo la voz del narrador o del héroe para relatar la historia nacional sino mediante estrategias fónicas y semánticas - por ejemplo, las repeticiones- que impregnan de ritmo y melodía a la prosa novelística:

Cantan siempre. No cesan porque no tienen trabajo, por eso no cesan de cantar. Van y vienen a todas horas, van y vienen siempre cantando, y a veces, se detienen para tomar un poco de café, para apuntar a veces algunos números, y luego, siempre cantando, pasar de un lado a otro, de un lado a otro de la calle. Siempre cantando, entre tirada y tirada. Nunca cesan, nunca (271).

Si la historia nacional no puede fundarse mediante la actuación homérica del personaje principal ni en la voz autorial de un narrador- cantor (juglar) que componga los sucesos, tampoco puede hacerlo en la construcción del espacio y el tiempo, dos aspectos de suma importancia en la narrativa heroica, y estrechamente relacionados con el tema del viaje, a los que, en Gestos, Sarduy les otorga características particulares. En este caso, adelantando un tópico que será propio de su narrativa posterior, aunque con algunas diferencias significativas, y que formará parte de las características de la poética neobarroca, instaura la ambivalencia en la representación del tiempo y del espacio mediante el uso de la simulación como recurso que le permite jugar con dos realidades superpuestas, una de 
las cuales aparenta gozar de la condición de verdadera en mayor medida que la otra.

Es así como nos encontramos, por un lado, con un espacio con referencia extraliteraria que constituye un anclaje geográfico más o menos concreto como La Habana donde, por indicios nunca del todo explícitos, ubicamos la acción. En ella transcurre la vida y el deambular permanente; en ella se danza y se canta y ese parece ser el canto de quienes hacen la historia cotidiana de Cuba; en ella se desarrolla un tiempo que parece avanzar hacia la bomba y, por consiguiente, la Revolución.

Por el contrario, también hay un espacio simulado, propio de un marco mítico-literario, occidental, culto: la Tebas de la representación teatral en la que la mulata es protagonista de la tragedia griega que ensaya. Pero también, es protagonista de una tragedia caribe que se desdobla en el pasado batistiano de la historia narrada y en el presente del contexto de producción sarduyano en el que el abuso de poder del que da cuenta la obra de Sófocles se vislumbra en la historia de una revolución que de a poco se irá transformando desde una esperanza liberadora a un enfrentamiento entre "hermanos" por el que una parte del pueblo quedará, necesariamente, fuera de las puertas de la ciudad ${ }^{44}$.

\footnotetext{
${ }^{44}$ De más está decir que Antígona ha dejado tras de sí una invalorable tradición literaria y crítica a lo largo de toda la historia cultural de Occidente. En Latinoamérica apareció, según María del Carmen Bosch, a mediados del siglo XX con obras como Antígona Vélez (1950) de Leopoldo Marechal, La hojarasca (1955) de Gabriel García Márquez, Antígona en el infierno (1958) de Rolando Steiner, Pedreira das Almas (1958) de Jorge de Andrade, Antígona-humor (1968) de Franklin Domínguez, entre otras.

En Cuba, el referente más conocido, al cual Sarduy se anticipa, es Los siete contra Tebas (1968) de Antón Arrufat. Esta obra es paradigmática no sólo por el planteo estético sino también porque su contenido - la guerra entre hermanos por el reino de Tebas como parábola del cismo político de la isla (Rojas 2009) - fue uno de los argumentos esgrimidos por la UNEAC - Unión de Escritores y Artistas de Cuba - para censurarla aún después de haber obtenido el premio de teatro de ese año. Tal como sucedió con el también discutido premio a Fuera del juego de Heberto Padilla, la obra fue publicada con la Declaración en la
} 
Esta idea se refuerza porque ambos espacios/ tiempos se representan de la misma manera. Sin avisos, sin indicaciones, nos encontramos con la presentación en un aquí y ahora enunciativos que nos desplazan desde las calles habaneras regadas todavía por el polvo y el ruido de la última bomba a la ciudad griega mediante una descripción que pone el relieve en la credibilidad de la representación:

Estamos en Tebas. Amanece. Las ráfagas levantan el polvo seco y lo ciernen sobre las ramas negras de los pinos. He aquí la base de una columna, el cuerpo achatado que se ensancha, el capitel grueso de doble voluta. Una puerta de hierro. Los relieves de cuatro cabezas; las dos superiores quizá humanas, de ojos bruñidos, se miran a través de las líneas que las separa; las dos inferiores, de león, están rodeadas de mechas lacias que se trenzan bajo las bocas de una barba escamosa (313).

De este modo, las dos referencias espaciales que presenta la novela se unen en la figura de la mujer pero lo hacen mediante la representación, la puesta en escena, la simulación de manera que un nuevo tema que se instaura como problema es el del origen en tanto, si Tebas es la ciudad mítica del origen de la cultura occidental por excelencia — cuna de Edipo, de la tragedia y la épica, cuyas murallas, se dice, fueron construidas por el canto- en el relato de Sarduy se encuentra en una Habana acosada por la opresión y la violencia, por la revolución o el desencanto, una Habana que canta el canto de los negros, de los chinos, de las mujeres, de las lavanderas y las revolucionarias. Es una Habana que no busca sus orígenes sino que los Cuba rechaza el contenido ideológico del libro de poemas y de la obra teatral premiados. Es posible que tal medida pueda señalarse por nuestros enemigos declarados o encubiertos y por nuestros amigos confundidos, como un signo de endurecimiento. Por el contrario, entendemos que ella será altamente saludable para la Revolución, porque significa su profundización y su fortalecimiento al plantear abiertamente la lucha" (1968: 15-6). 
pone en diálogo, los hace jugar, los representa en la construcción cultural de una nación que no se pretende ni heroica ni trágica sino revolucionaria.

Porque también hay espacios y tiempos -y, por lo mismo, historiassugeridos, apenas mencionados, que entran en este juego de referencias de una manera mucho más velada y subrepticia y que configuran una narración intersticial por la que se cuelan elementos que constituirán las continuidades de la obra sarduyana. Es Oriente y el comienzo del proceso revolucionario como así también es la caravana y la entrada de Fidel Castro/ [Cristo] en La Habana. Es, por lo tanto, la historia contada de la dictadura de Batista y la que está comenzando a contarse -y continuará en De donde son los cantantes- del inicio de la Revolución. Pero también es la historia insinuada de la relación conflictiva que esta misma Revolución establecerá con sus artistas, que se vislumbra en Gestos a través de las quejas constantes de la mulata ante la obligación de poner la bomba y la difícil congruencia entre la función de artista y la de revolucionaria, y que se percibirá como críticas veladas en la obra posterior del cubano.

Me permito concluir afirmando que, vista como ejemplo de la novela épica de la Revolución por parte de la crítica, Gestos presenta, en verdad, una serie de características por las cuales considero que no se puede adscribir, sin más, a este modelo canónico. Por el contrario, una lectura que revisa esta problemática advierte que, si bien existe una estructura que mantiene legibles ciertas convenciones del género narrativo, hay un trabajo con el lenguaje que —en virtud de sus novelas posteriores diría que es apenas incipiente- adelanta lo que luego será constitutivo de la escritura 
sarduyana y pone los primeros fundamentos de una poética que adoptará visos de singularidad sellada por la fragmentación y la extravagancia.

El contexto histórico de producción pone a Gestos en los comienzos de una carrera intelectual más marcada por el triunfo reciente de la Revolución que por las innovaciones teóricas, críticas y filosóficas que devendrán con la aparición en escena del grupo Tel Quel y el postestructuralismo. La problemática de la identidad se plantea, entonces, como una noción en la que es posible hablar de ciertos sujetos culturales —chinos, negros, mulatos- en diálogo. Sin embargo, la presencia de algunos rasgos propios del nouveau roman francés y de otros más cercanos al neobarroco latinoamericano no sólo adelantan una poética sino también proponen cierto desplazamiento por el cual esta categoría de sujeto está marcada por un viaje que no es de autorreconomiento y aprendizaje sino de crítica a ciertos cánones formales y de cuestionamiento a una noción cara a las políticas socio-culturales del gobierno revolucionario como fue el mestizaje. Claro que éste es un viaje del que Gestos es sólo uno de los comienzos posibles para un periplo que se irá construyendo en los pliegues y reveses de una narrativa cada vez más signada por la interrogación. 


\title{
II. 2. Mamá yo quiero saber... De donde son los
}

\section{cantantes: la elusión de una respuesta}

\begin{abstract}
Naturalmente no toda la literatura latinoamericana ofrece el mismo sentido, pero vastos sectores de ella parecen aconsejarnos olvidar la obsesión por una identidad que nos defina para siempre [...] a la vez que nos reta a la aventura de instalarnos en el riesgoso pero incitante margen donde yo y el otro se confunden frente al hirviente espejo de un mundo que acoge sin reparos mutaciones y disidencias.
\end{abstract}

Antonio Cornejo Polar, Escribir en el aire (1994)

He aquí el resumen de mi metáfora: palabras cojas para realidades cojas que obedecen a un plan cojo trazado por un mono cojo.

Severo Sarduy, De donde son los cantantes

La posición de colonialidad en la que los pueblos de América Latina quedaron subsumidos por el proceso de conquista y colonización que comenzó en el año 1492 ha hecho de la cuestión de la identidad una problemática fundamental en la región. Es por esto que la pregunta por el quiénes somos es una constante que se repite en el tiempo y no sólo a partir de los abordajes de los críticos y teóricos de la cultura sino también de aquellos que se consideran y/o son considerados artísticos, fundamentalmente, los pertenecientes al campo de la literatura ${ }^{45}$.

La pretensión de responder este interrogante ha dado lugar, por una parte, a muy disímiles conceptualizaciones en torno de la noción de

\footnotetext{
${ }^{45}$ En este sentido, vale la afirmación de Ana Pizarro según la cual "Son los procesos de descolonización y la implicación que ellos tienen en la conformación de las sociedades nuestras poliétnicas y plurilingües, y en el caso de América Latina, mestizas, los desencadenantes de la llamada "búsqueda de identidad"” (1987: 151).
} 
latinoamericanidad. Por otra parte, intentos de ordenamiento y clasificación tales como las historias literarias constituyen otro ejemplo del esfuerzo que ha realizado, y realiza, al menos un sector del campo intelectual latinoamericano por responder a la pregunta sobre nuestra identidad. Sin embargo, el abanico de posibilidades que ofrece la literatura de América Latina plantea dificultades por las cuales no es éste un tipo de discurso que pueda ser elaborado de la misma manera en que lo fueron, por ejemplo, las historias literarias europeas. En este sentido, el afán por encontrar una respuesta a este problema ha llevado al replanteamiento de los puntos fundamentales de este tipo de discurso: por dar algunos ejemplos, los que tienen que ver con el objeto de estudio y la metodología de trabajo ${ }^{46}$.

De esta manera, la literatura y la crítica literaria se constituyen en superficies de emergencia y ámbitos de producción de la latinoamericanidad y se instauran como modelos de pluralidad, contradicción y dialogismo, es decir, dan cuenta de la heterogeneidad intrínseca de la sociedad que las produce en contraposición con los cánones de homogeneidad cultural metropolitana: "Las encrucijadas de nuestra crítica, entonces, se han ido resolviendo haciendo de la crisis un modo cotidiano de reflexión; las estrategias se han ido formulando a partir, no de

\footnotetext{
${ }^{46}$ Desde el concepto de literatura entendido como "belles lettres" se ha desplazado la mirada hacia el concepto de discurso, por lo que el campo de estudio se ha ampliado significativamente y, para quienes defienden esta postura, se ha democratizado. En lo que concierne a la metodología, la perspectiva comparatista se presenta como una posibilidad más fructífera que la pura linealidad, a la que nos tienen acostumbrados las historias literarias clásicas, de dar cuenta de la yuxtaposición - de tiempos, de problemáticas, de culturas- y la complejidad del campo que nos ocupa. Uno de los textos, pero no el único, en los que se puede encontrar esta propuesta es el trabajo de Rolena Adorno. (1988). "Nuevas perspectivas en los estudios literarios coloniales". Revista de Crítica Literaria Latinoamericana XIV, 28, ( $2^{\circ}$ semestre): 11-27. Como ejemplo de una mirada crítica sobre este aspecto ver Larsen, Neil. (1993). "En contra de la des-estetización del "discurso" colonial". Revista de Crítica Literaria Latinoamericana XIX, 37, (1ºmestre): 335-342.
} 
modelos teóricos, sino de escrituras sobre, y lecturas de, novelas y poemas que eran asumidos como nudos de conflicto" (Mariaca Iturri 1993: 2). Sin embargo, como instituciones que crean y definen objetos de estudio, son las responsables de llevar adelante el proceso de inclusión y exclusión que canoniza u olvida autores, obras, movimientos, es decir, determina qué se puede o no leer, quiénes leen a quiénes, cómo y cuándo lo hacen (9).

Visto de esta manera, puede afirmarse que la formación del canon latinoamericano no se basa en criterios puramente metodológicos sino en términos de políticas culturales puestas en práctica en función del contexto histórico, las restricciones institucionales y las condiciones de reproducción de los textos. De esto se desprende, por un lado, que el análisis de la crítica es, al mismo tiempo, un análisis de estas políticas y una explicación del canon vigente; por el otro, que esta crítica $-\mathrm{y}$ como consecuencia, el canon - se construye al ritmo de los desafíos teóricos que impone el campo intelectual.

\section{2.1. La desterritorialización}

De donde son los cantantes (1967), segunda novela de Sarduy, fue escrita y publicada estando ya su autor radicado en Francia y vinculado al grupo Tel Quel. Varios datos, en realidad, a la luz de los cuales, la obra mencionada adquiere una significación especial a partir de la que es posible, incluso, releer Gestos retrospectivamente otorgándole una nueva dimensión que permita establecer algunas rupturas y continuidades en la narrativa sarduyana aunque, lo que a primera vista saltan, son las enormes 
disimilitudes que existen entre ambas novelas. Una de las diferencias más notorias se da a nivel de la trama argumental ya que, si en Gestos se cuenta una historia en la que los principales elementos de la narrativa convencional —espacio, tiempo, personajes, narrador, descripciones- aparecen de modo claro y con ciertas precisiones, en De donde son los cantantes lo que se cuenta, en principio, son tres historias a las que se suma la "Nota" en la que el autor reflexiona sobre la obra y la cuestión de la identidad que allí se ficcionaliza y el "Curriculum cubense" que da inicio a la novela y presenta a los personajes.

En la primera de estas historias — “Junto al Río de Cenizas de Rosa" - la trama transcurre en torno a tres vedettes, travestis dedicadas a la prostitución, de "El Shanghai" — burlesco ubicado en el barrio chino—y un General español enamorado de una de ellas: Flor de Loto. Las otras dos son las gemelas Auxilio y Socorro que hacen su primera aparición novelesca aquí pero que constituirán una presencia constante en las demás obras, aún cuando en algunas aparezcan metamorfoseadas o con otros nombres. Estas actúan en esta novela a la manera de celestinas que le sacan regalos y dinero al General.

Finalmente, cansado de los desplantes de Flor, el Gene -así lo llaman las gemelas_le envía una pulsera provista de navajas que tiene la funcionalidad de cortarle las venas. Según Justo y Leonor Ulloa, esta relación entre el General y Flor de Loto impone en el capítulo una estructura binaria "perseguidor/ objeto de su persecución" que se sustenta en la lógica del deseo a partir de la cual se proyectan y ramifican las diferentes facetas del relato y que permite, a través de las situaciones por las que atraviesa el 
General durante su persecución, intercalar en el episodio algunos elementos que consideran significativos del mundo chino: el deseo, el estatismo y la acción extrema - estos últimos alternando entre sí alrededor del deseo puesto como centro (1975: 570).

Sin embargo, el deseo no sólo se manifiesta en la persecución del General sino también a nivel textual en tanto escritura que excede el nivel denotativo; retórica neobarroca que pone sus fundamentos en la materialidad del signo, en el brillo del significante, en la proliferación de procedimientos cuya función principal es la de diferir, desplazar y ocultar todo significado, todo centro, todo sentido. Así, según Adriana Méndez

La configuración de este deseo textual, reproduce la figura parabólica de la palabra: un falso ser (centro, sujeto ausente) persigue a otro, sin alcanzar la consumación del deseo. De la misma manera que la palabra nunca recupera el significado, el sujeto (falso) siempre se desliza en busca del otro, falso sujeto, que es, a la vez, objeto (1978: 47).

Si la metonimia es la figura fundamental del diferir y el desplazamiento y, por lo mismo, la que mejor representa la búsqueda para siempre infructuosa del objeto perdido, del objeto del deseo, la metáfora somática en este capítulo es el procedimiento retórico privilegiado para entablar una relación triangular entre cuerpo, escritura y erotismo que, si bien aparece en menor medida en Gestos, a partir de De donde son los cantantes será una constante de la novelística sarduyana ${ }^{47}$. En esta línea de

\footnotetext{
${ }^{47}$ Para Alicia Rivero Potter son dos las principales metáforas somáticas y eróticoescripturales que aparecen en De donde son los cantantes: la del "autor tatuador" y la del "cuerpo como libro/libro como cuerpo" (1983: 497). Ambas provienen no de cultos orientales sino del yoruba y el cristianismo. En el mismo artículo se ocupa, también, de estas metáforas en Cobra por lo cual concluye que: "Existe un paralelo entre Eustaquio y Sarduy: ambos escriben textos; la actividad escriptural de Eustaquio espejea la de Sarduy, pero la grafía erótica y lúdica de éste está en un libro, Cobra, y la de aquél se encuentra sobre cuerpos" (502).
} 
análisis, Méndez concluye que en la novela se utilizan diferentes figuras retóricas como estrategia que permite mostrar cambios en el cuerpo según va cambiando la raza que lo conforma: "Cada raza tendrá un lenguaje propio - la china, metafórico, la negra, coloquial, la blanca, retórico (históricoliterario- para componer un cuerpo particular" (48). Esto pone en evidencia la impostura del ser en correspondencia con la pura materialidad del significante y, en consecuencia, señala la desintegración del sujeto-autor (59). En el mismo sentido, Julio Ortega afirmaba algunos años antes que los tres elementos glosados son vistos como espectáculo puro por lo que su esencialidad está descubierta por sus apariencias: "lo "chino" es un objeto tipo, lo "negro" una voz llena, lo "hispánico" una estatua de madera que se pudre en el mito de las significaciones" (1973: 163).

En resumidas cuentas, tal como lo afirma en la "Nota", Sarduy ficcionaliza en esta historia la presencia de ciertos aspectos de la cultura china en la conformación de la cultura cubana. Si bien es éste un elemento que ya había aparecido en Gestos, lo que en esta primera novela fue una descripción no exenta de cierto distanciamiento en relación con la figura del narrador y puesto como un constructo en diálogo con los demás componentes de la cultura pero sin fuertes imbricaciones entre sí, en $D e$ donde son los cantantes se presenta como una "china de pacotilla" en la que no existen realidades esenciales susceptibles de ser encasilladas tal como "La cultura china" sino imágenes, representaciones, puestas en escena de una realidad hecha de muchos, variados y contradictorios elementos que se superponen, se entremezclan, se enfrentan y dialogan ${ }^{48}$.

\footnotetext{
${ }^{48}$ Aunque es una presencia que ha sido muy poco trabajada por los estudiosos, González Echevarría señala que a partir de 1853 , fundamentalmente, se dio una importante
} 
El final trágico que espera a Flor de Loto adelanta el comienzo de la segunda historia — "La Dolores Rondón"—que se inicia con el epitafio de Dolores Rondón, en el cementerio de Camagüey, en el que se narra, en forma de décima, la historia de su vida y que funcionará como eje estructurante de todo el capítulo. Como consecuencia de esto, la historia no será contada según la secuencia lógica temporal de los hechos sino en función de la organización lírica de la décima que comienza con la muerte de la mulata. Según González Echevarría, comenzar con la muerte es equivalente a empezar por lo oriental, ya que "éste representa la fijeza, lo que se erige sobre la nada" (1987: 113) en tanto remite al origen impostado, erróneo de Colón que lo lleva a pensar que Cuba es Cipango. De esta manera se establece una nueva relación entre los distintos componentes culturales, en este caso, lo chino, lo negro, lo mulato ${ }^{49}$.

Dolores es una mulata humilde del interior del país que viaja a Camagüey con la intención de encontrar mejores oportunidades para su vida. Allí seduce y se casa con Mortal Pérez, candidato a concejal, blanco, que asciende rápidamente en la política hasta llegar al círculo inmediato del presidente — probablemente Batista— en La Habana, y con él, ascienden también los lujos y caprichos de Dolores. Un traspié en su forma de actuar —le provee al presidente una mulata camagüeyana haciéndola pasar por una bailarina hawaiana - lo pone en desgracia con el poder y pierde su lugar y sus privilegios. Dolores debe regresar a Camagüey donde muere en la pobreza. Esto representa, para González Echevarría, la sumisión que la raza

incorporación de chinos en Cuba. Esta inmigración continuó después de la independencia al punto de que se formó en La Habana un barrio chino.

${ }^{49}$ La representación de lo oriental aparece, de una u otra manera, en la mayoría de las obras sarduyanas. Un aporte al respecto es el trabajo mencionado de Julia Kushighian. 
negra sufre en Cuba sometida a los caprichos de la blanca "la tragedia de la esclavitud que vicia el origen de la historia de la isla" (114). En mi opinión, aquí vuelven a entroncarse dos problemáticas fundamentales en la historia de Cuba que, de una manera u otra, serán retomadas en las novelas posteriores. Me refiero concretamente a la presencia de la dominación por la raza pero también a la que se ejerce en relación con el sexo y, por extensión, con la prostitución. Si en Gestos la mulata actuaba como revolucionaria compelida por su novio blanco, en De donde son los cantantes Dolores usará su seducción erótica como un medio para ascender socialmente. Pero también, veremos más adelante, Colibrí es perseguido por la Regente para obligarlo a saciar sus placeres sexuales y prostituirse en la Casona y Cocuyo descubre una historia de prostitución en la que mantienen, probablemente esclavizada, a Ada y, por analogía, es de suponer que también a su hermana. Así, se urde una trama en la que sexo y raza constituyen los dos extremos de un relato de dominación con un referente común que atraviesa la historia cubana desde sus inicios y que constituyó una de las preocupaciones fundamentales del proyecto político y social de la Revolución de 1959, y un referente literario, más ilustrativo, que es la ya mencionada Cecilia Valdés o La loma del Ángel, de Cirilo Villaverde.

Por su parte, Auxilio y Socorro también aparecen en este capítulo, esta vez acompañando a Dolores, como sirvientes fieles, costureras o en el personaje que les toque según la antojosa determinación de los narradores ${ }^{50}$. Más que personajes, entonces, Auxilio y Socorro son una sucesión

\footnotetext{
${ }^{50}$ En el artículo "Leyendo las huellas de Auxilio y Socorro", Leonor de Ulloa y Justo Ulloa analizan exhaustivamente el recorrido que ambos personajes realizan en la novela sarduyana y concluyen que "la trayectoria de Auxilio y Socorro se logra por medio de una superposición o montaje de palabras, sintagmas, textos y cuadros de referencias culturales que nos llevan desde la España musulmana hasta Cuba" (s/d: 23).
} 
interminable - casi podría decirse, metonímica- de transformaciones por las que es imposible encasillarlos en alguna característica particular que los identifique o que marque un posible origen en ellos. Por esto y por su también inacabable transformación genérica, Auxilio y Socorro constituyen un soporte más sobre el que se sustenta la interrogación sarduyana en torno a la subjetividad, la identidad, el origen, el cuerpo. En este sentido, Gustavo Pellón, en un análisis comparativo entre la obra novelística de Sarduy y la de Juan Goytisolo afirma que, entre los cánones de la narrativa que ambos autores pretenden cuestionar, el desarrollo de la trama y la elaboración de personajes con "espesor psicológico" son los principales. Estos, aunque ya habían sufrido "el zarandeo de la vanguardia y el surrealismo, todavía tenían vigencia en la novela existencialista" (1988: 484) por lo que la creación sarduyana constituye un nuevo, aunque no aislado, intento por problematizar ciertas cuestiones inherentes a la producción literaria.

Por otro lado, estos dos personajes, que hasta ahora se han presentado como secundarios en el eje de la historia, cobran importancia singular cuando advertimos que son los encargados de llevar adelante la última de las ficciones, dedicada a representar en este "curriculum cubense" al componente blanco. En "La entrada de Cristo en La Habana" las gemelas aparecen, en primera instancia, en España, buscando a Mortal quien cada vez más nos remite a una vinculación estrecha con el General de la primera parte. Desde un Cádiz impregnado por la atmósfera árabe, estos mismos personajes se lanzan a la conquista de América "documentada" por la inclusión de un diario de viaje que, si bien en el título es presentado como 
de Auxilio y Socorro, una referencia a pie de página desmiente esta información atribuyéndoselo a Colón:

Por la noche navegamos lentamente, por miedo a atropellar tritones; éstos nos asediaron en bandas de hasta ciento y no nos abandonaron sino hasta el alba, enredados entre los sargazos. Pasaron muchos pájaros y ángeles que no se alejan nunca a más de una milla de la costa, así es que la tierra debe estar cerca... (1999 [1967]: 394).

Inmediatamente después, aparecen en la catedral de Santiago de Cuba desde donde inician una procesión que tendrá como objetivo final llevar un Cristo de madera, que se va pudriendo y despedazando poco a poco, hasta La Habana. Éste es un viaje que se inicia en oriente y llega a occidente — de la loma al llano- y que, en consecuencia, puede ser leído como el recorrido que realizaron los revolucionarios de Fidel, también desde Santiago hasta la capital: "La entrada de Cristo/ [Castro] en La Habana".

Así, tenemos en la trama de esta novela todos los interrogantes que se plantean desde el título el cual nos remite a la tradición poética y musical cubana en tanto es un verso del "Son de la loma" de Miguel Matamoros, integrante del "Trío Matamoros" que tuvo éxito en Cuba a partir de los años ‘20 ${ }^{51}$. Pero, tal como lo desarrolla González Echevarría, lo más importante de este sintagma es la ambigüedad semántica y gramatical con la que está construido ya que, sin acento en el "donde", constituye una afirmación hecha según el modelo usual de una pregunta por lo que se instituye en ambas cosas al mismo tiempo. Pero también, es un circunloquio en el que lo no dicho, pero presupuesto, es el significado inicial, Cuba (1987: 102).

\footnotetext{
${ }^{51}$ Transcribo la letra del son citada en el trabajo de González Echevarría: "Mamá yo quiero saber, / de dónde son los cantantes, / que los veo tan galantes, /y los quiero conocer, /con su trova fascinante, /que me la quiero aprender. / ¿De dónde serán, ay mamá, /serán de La Habana, /serán de Santiago, /tierra soberana? /Son de la loma, / y cantan en llano, / tú verás, vamos a ver, / Mamá, ellos son de la loma, /mamá, ellos cantan en llano, /Mamá, ellos son de la loma. (bis)" (1987: 104).
} 
Por su parte, José Amícola ve en la presencia de la cultura de masas que este título supone un eje conductor entre De donde son los cantantes y Tres Tristes Tigres (1967) de Guillermo Cabrera Infante en el que el bolero en clave paródica es el elemento que permite subvertir un discurso institucionalizado —el de la literatura "altisonante" de Carpentier, Lezama o Vitier - acerca de cómo debía entenderse la nacionalidad (2000: 160-70) ${ }^{52}$. En la primera frase del capítulo se refuerza esta idea de la parodia a la "alta" literatura en función de dos elementos fundamentales. Por un lado, el "sî" que hace referencia al "sî" con el que se cierra el monólogo de Molly Bloom en el Ulysses (1922) de James Joyce impone en la novela de Sarduy una parodia en segundo grado e introduce un elemento inesperado, lo camp, en tanto se hace eco de una exageración de los atributos de la femineidad propia de la cultura actual. Por el otro, una alusión clara a la cultura homoerótica cubana - los pájaros, las plumas - retoma y refuerza esta noción de camp manifestado a través de la estetización de lo homosexual y la cultura de masas (170).

Se puede afirmar, entonces, que la novela constituye desde el título y hasta la nota final una pregunta acerca de qué es Cuba: ¿lo chino, lo mulato, lo blanco? ¿Oriente u occidente? ¿Castro, la revolución y los revolucionarios? ¿La Dolores Rondón y el batistato? ¿La pregunta del título, la afirmación o la explicación final de la obra?

\footnotetext{
52 Carolina Sancholuz, Roxana Paez y Néstor Ponce emplean el concepto de ritornelo definido por Gilles Deleuze y Félix Guattari como "todo conjunto de materias de expresión que traza un territorio y que se desarrolla en motivos territoriales, en paisajes territoriales" (citado en Sancholuz y otros 1998: 65) para afirmar que "A Sarduy el exilio, el desplazamiento de Cuba a París, le permite conjurar la quimera del origen. Un distanciamiento de lo natal, que posibilita, sin embargo, un ritornelo, un agenciamiento territorial para recuperar a Cuba, a través de la relectura y redescubrimiento de sus "mayores"” (72).
} 
En relación con esto, considero que la noción de “desterritorialización” teorizada por Gilles Deleuze y Félix Guattari en Kafka: por una literatura menor (1975) es un aporte que permite aventurar posibles puntos de acercamientos a los interrogantes planteados.

En el libro mencionado, Deleuze y Guattari le dan operatividad a su análisis a partir de la reflexión en torno a la escritura kafkiana con el propósito de introducir y desarrollar la noción de "literatura menor". Según estos autores, esta noción no implica una literatura producida en un idioma menor, sino la literatura que una minoría hace dentro de una lengua mayor (1998 [1975]: 28) y que se define en función de tres características principales: la desterritorialización de la lengua, la articulación de lo individual en lo inmediato- político y el dispositivo colectivo de enunciación (31).

Desterritorializar una lengua, hacer de una literatura una literatura menor es un ejercicio que exige minar el lenguaje, hacerlo huir hacia sus extremos al punto que deje de ser representativo: "Servirse del polilingüismo en nuestra propia lengua, hacer de ésta un uso menor o intensivo, oponer su carácter oprimido a su carácter opresor, encontrar los puntos de no-cultura y de sub-desarrollo, las zonas de tercer mundo lingüístico por donde una lengua se escapa" (44). La desterritorialización puede ser absoluta, cuando se trata, por ejemplo de la metamorfosis, o relativa, en los casos en los que el hombre realiza en sí mismo al desplazarse, al viajar (56).

Más allá de estas clasificaciones, creo que lo relevante de este concepto está en ponerlo en relación con las otras dos características 
enunciadas por Deleuze y Guattari como propias de la literatura menor. Estas son: el carácter político, por un lado, y el colectivo, por el otro; ambos estrechamente relacionados entre sí en tanto, según los autores, el "espacio reducido [de una literatura menor] hace que cada problema individual se conecte de inmediato con la política" (29) por lo que esta, a su vez, contamina cualquier enunciado de manera que, cuando la conciencia nacional se encuentra inactiva y dispersa la literatura asume el papel de la enunciación colectiva e incluso revolucionaria (30).

Y así sucede, en mi opinión, en De donde son los cantantes, ya que los interrogantes sobre la identidad — la cubanidad—, no sólo se plantean en el plano argumental sino que minan el lenguaje, lo hacen huir hasta sus extremos, desterritorializan la lengua que es una forma de desterritorializar también las respuestas absolutas porque no hay quien las dé ni cómo darlas.

El punto es que, a la construcción fragmentaria de la historia, se suma un trabajo con el lenguaje que pone en cuestión la voz de la enunciación y, con ella, al modo enunciativo. Esto es Sujeto y Literatura puestos en situación, no de pulverización, como veremos en Cobra, sino de cuestionamiento, de problematización, de desterritorialización. Se construye aquí una trama textual que, aunque mantiene la estructura básica de una novela, se hace y se deshace constantemente en múltiples formatos en tanto los que se multiplican son, en primera instancia, los enunciadores.

Encontramos entonces, conviviendo con la narración básica, una estructura dialogada que se presenta en las voces de dos narradores que a veces cuentan los sucesos y otras veces reflexionan, no sin ironía y humor ácido, en torno a la construcción del relato: 
NARRADOR UNO (corifeo de vocecilla chillona, ácida): ¡Ah, sí, ponerse a escribir otra vez, qué vomitivo! ¡Como si todo esto sirviera para algo, como si todo esto fuera a entrar en alguna cabezota, a entretener a alguno de los lectores babosos, ovillados en sus poltronas, frente al sopón soporífero de cada día!

NARRADOR DOS (corifeo sentencioso, grave, de voz engolada): Pues sí, descifra o revienta: todo sirve, todo es definitivo, todo vuelve al todo, es decir a la nada, nada es todo (se raspa la garganta)...con ese juego de palabras quiero decir que tu vomitivo es muy útil, útil porque vomitivo, en fin, con palabras se modifican las cosas, los comportamientos, el comportamiento de las (se detiene en seco, da un coturnazo en el suelo) [Itálicas y mayúsculas en el original] (1999 [1967]: 361).

Junto a las acotaciones, se impone, dentro del relato, una estructura teatral clásica que incluye a los narradores en función de personajes y los hace actuar sumando sentidos y dispersiones al sentido general al punto de que, en algunos episodios, los personajes de la novela son conscientes de la transformación de la historia producida por esta presencia que, aunque insólita para las convenciones del género, son aceptadas por ellos sin sorpresas:

DOLORES (que ha escuchado la conversación entre los narradores): ¿Cómo? ¿Qué dicen esos viejos chochos que están allí? ¿Que me quedo? ¿Que aquí finalizo mi carrera? Ahora verán. ¡Oye, galleguito! Tú, el de la boina, tú mismo [Itálicas y mayúsculas en el original] (362).

La intromisión de la voz de la enunciación en el enunciado es un recurso recurrente en toda la novela y uno de los puntos de contacto con las demás novelas sarduyanas, a excepción de Gestos en la que no aparece con la misma frecuencia. Sin embargo, no es el único procedimiento utilizado para poner en entredicho el estatuto institucional y canónico de la Literatura como entidad. Esto se logra, además, con la inclusión de comentarios y tipos discursivos que tienen como funcionalidad develar el carácter de 
construcción ficcional de la escritura, por ejemplo, las notas a pie de página, una intromisión cualquiera del narrador, las constantes alusiones e intervenciones del lector: "retrocede y aparece la Reina de las Grullas (¿la reconocen?, ¿adivinan quién es? Mírenla bien y sabrán —respuesta tres líneas más abajo- - y la Reina de los Halcones (que en la leyenda es un Rey, pero la metamorfosis no da para tanto)" (355), la "Nota" incluida al final de la novela, en la que el propio autor da su explicación de la misma, y el "Curriculum cubense", otorgando al relato un marco que lo contiene pero, a la vez, lo interpela y lo obliga a excederse en su condición de tal.

Por otra parte, hay referencias del discurso publicitario, reminiscencias irónicas y humorísticas del discurso bíblico e innumerables relaciones intertextuales que tanto remiten a los cánones clásicos considerados de literatura culta -Garcilaso, Quevedo, Manrique, Goytisolo - como a expresiones de la literatura popular, ya sean canciones, coplas o refranes: "En el bosque de La Habana/ una china se perdió,/ y como yo era un perdido/ nos encontramos los dos" (337).

En resumidas cuentas, si de sujetos, historia y literatura está hecha una nación y son éstas construcciones fragmentarias, desgarradas, intersticiales, ¿cómo pensar la cubanidad si no es a partir del fragmento y la dispersión? ¿Es posible pensarla apelando a la metáfora del mestizaje ${ }^{53}$ Sí, si lo que se pretende es construir un discurso tranquilizador que disuelva las contradicciones constitutivas de la nación con el fin de crear un proyecto

\footnotetext{
${ }^{53}$ Para un desarrollo exhaustivo de la metáfora del mestizaje como estrategia de la ciudad letrada cubana para pensar la nacionalidad, ver Duno Gottberg, Luis. (2003). Solventando las diferencias. La ideología del mestizaje en Cuba. Madrid: Iberoamericana.
} 
político y social - tal como fue la propuesta de la Revolución Cubana- que incluya sin diferenciar, al menos en lo discursivo y en sus primeros tiempos, en un "nosotros" capaz de oponerse a la amenazante presencia del "otro" que instituye su propio proyecto. Roberto Zurbano Torres, analizando el discurso sobre la nación en el contexto revolucionario de los años sesenta, afirma que el sujeto de las transformaciones sociales propuesto por el proyecto revolucionario es un "sujeto supraindividual que está más allá de su condición sexual, racial o social. Enfatizar alguna de estas subjetividades sería fragmentar - dividir era la palabra de uso- el sujeto protagonista de dichas transformaciones" (11).

Sarduy, por el contrario, "aprovecha" - afirma González Echevarría refiriéndose a De donde son los cantantes- "la ruptura histórica, política y cultural que constituyó la Revolución para someter al discurso de lo cubano -y por extensión de lo latinoamericano- a un análisis disolvente que marca un hito en la literatura de la identidad en América Latina; es decir, reelabora en su novela el mito de lo nacional pero poniendo en evidencia "todo aquello que era necesario velar para preservar la coherencia de planteamientos anteriores de la cultura cubana y latinoamericana [...], ilumina una especie de subconsciente cultural, liberando lo que permanecía reprimido" (1997: 57).

De modo que, De donde son los cantantes se inserta en un larga tradición de escrituras en torno al problema de la identidad cubana que se extiende desde Martí a Roberto Fernández Retamar pasando por obras como Indagación del choteo (1927) de Jorge Mañach, Americanismo y cubanismo 
literario (1932) de Juan Marinello, "Los negros y la cubanidad" (1939) de Fernando Ortiz, La expresión americana (1957) de José Lezama Lima, Lo cubano en la poesía (1958) de Cintio Vitier, Tientos y diferencias (1962) de Alejo Carpentier (56) pero ya no con la intención de sostenerla sino, por el contrario, marcando los reveses de esta escritura que es vista desde atrás, "desde las costuras, desde sus mecanismos de construcción, aun o sobre todo de aquellos de los cuales estamos menos conscientes" $(57)^{54}$.

Así, si la tradición del mestizaje ha permitido ver la identidad cubana como "una nueva cultura nacida de la interpretación y de la conjugación de los contrarios" (Gruzinski 2000: 45) ${ }^{55}$ Sarduy nos ha trazado, desde su "Curriculum cubense" y a lo largo de toda la novela, un mapa en el que la cubanidad está construida a partir de los más dispares elementos étnicos, culturales, geográficos, históricos, lingüísticos, genéricos, que no cohabitan apaciblemente - como sucedería en el mestizaje- si no que se yuxtaponen y se manifiestan en la heterogeneidad conflictiva de Cornejo Polar que

\footnotetext{
${ }^{54}$ Sarduy reconoce explícitamente a dos de los integrantes de esta tradición en el ensayo "Dispersión. Falsas notas/ Homenaje a Lezama": Martí y Lezama Lima. En un apartado del texto titulado "Escrito en cubano, afirma: "Quizás ha habido ya dos respuestas, en el nivel de la escritura, a la pregunta sobre el ser cubano: la palabra cubana ha llegado a su majestad dos veces. La primera es el Diario de Martí, esas últimas páginas cuando Martí vuelve a Cuba ya en vísperas de la muerte [...]. Esas páginas tienen un carácter casi alucinatorio. Desde el punto de vista del habla cubana son centrales: allí hay algo, allí hay una conmoción total, el ser cubano se expresa. [...] En ese momento, Martí sobrepasó el nivel de la significación, el verbo decir, Martí fue, fue eso, fue lo cubano. Ese umbral es la meta ideal de la obra de Lezama Lima" [Itálicas en el original] (1999 [1967]: 1173).

${ }^{55}$ La categoría de mestizaje con la que opera Gruzinski me resulta, en algunos aspectos, discutible. Si bien por un lado se posiciona en contra de las "aproximaciones dualistas [que] seducen por su simplicidad" (2000: 48) impulsando, de esta manera, un acercamiento a las culturas que tenga en cuenta los espacios intermediarios, por otro lado, cuando define el mestizaje como un proceso mediante el cual: "Los elementos opuestos de las culturas en contacto tienden a excluirse mutuamente y se oponen unos a otros; pero al mismo tiempo, tienden a penetrarse mutuamente, a conjugarse y a identificarse. [...] lo que permite la emergencia de una nueva cultura [...] nacida de la interpretación y de la conjugación de los contrarios" (45) pareciera dejar entrever que esta nueva cultura está formada por la fusión de las anteriores y que, por lo mismo, se presentaría como una síntesis que ha logrado anular los conflictos y las contradicciones.
} 
superpone tiempos y conciencias de las más variadas índoles ${ }^{56}$. Pero este es un mapa que "estriba en la estructuración de un universo donde el rito de la metamorfosis -multiplicidad gozosa de máscaras superpuestas- borra los límites "logocéntricos" del entendimiento para situar al lector en un nuevo estadio de comprensión” (Rodríguez Coronel 1993: 118); es decir, borra los límites de la palabra que nombra y clasifica, la trasviste como trasviste a sus personajes, invierte su sentido, dramatiza y pone en escena el trasfondo farsesco del discurso nacional, lo desenmascara en tanto construcción imaginada que se naturaliza y, por lo mismo, se arroga el derecho de incluir y excluir, de aceptar o exiliar. Por esto, De donde son los cantantes no constituye sólo la crítica a un modelo ni a un concepto de identidad sino la operatividad de una heterogeneidad en conflicto que pone en debate los fundamentos mismos de las narrativas totalizadoras porque las construye, como una literatura menor, sobre la desterritorialización de la lengua.

Metáfora/ metonimia, juegos de máscaras, metamorfosis, desplazamiento del autor, borramiento de los límites genéricos: una abundante, excesiva proliferación de marcas textuales que aluden y eliden un sujeto, una identidad. Pero, además, prefiguran un camino, el sinuoso camino, por más abundante y excesivo aún, del neobarroco sarduyano.

\footnotetext{
${ }^{56}$ En este sentido, Duno Gottberg afirma que "Sarduy es enfático en señalar que los elementos culturales que conforman lo latinoamericano coexisten como yuxtaposición de unidades heterogéneas o collage. Mientras unos piensan en términos de una dialéctica que alcanza su resolución en la síntesis cultural, Severo Sarduy se sitúa en el conflicto de lo dispar, situando ahí la especificidad de nuestra expresión” (2003: 216).
} 


\title{
II. 3. El exilio: neobarroco de la revolución
}

\begin{abstract}
¿No es el barroco la alegoría de nuestro mundo, un mundo después de la catástrofe, en el que el fragmento, las ruinas y el carácter óptico de todo real, serían los índices de una historia saturniana? Tal alegoría, irreductible a una simple encarnación de la Idea en el sentido tradicional del término, sitúa el sentido en superficie y en oblicuo todo un arte de la alusión y la ilusión. Entre su lluvia de imágenes y sonidos, y su estrategia fría, suspende la significación en los rasgos de un real irreal que pone en práctica lo irrepresentable.

Christine Buci-Glucksmann, "La manera o el nacimiento de la estética" (1993)

Barroco que en su acción de bascular, en su caída, en su lenguaje pinturero, a veces estridente, abigarrado y caótico, metaforiza la impugnación de la entidad logocéntrica que hasta entonces lo y nos estructuraba desde su lejanía y su autoridad; barroco que recusa toda instauración, que metaforiza al orden discutido, al dios juzgado, a la ley transgredida. Barroco de la Revolución
\end{abstract}

A partir del triunfo de la Revolución de 1959, se fue instaurando en torno a Cuba, un contexto en el que las hostilidades provenían desde los más diversos frentes y formaban parte de la realidad cotidiana. El gobierno castrista apeló a estrategias que, en el orden político y económico, pusieron en funcionamiento un programa socialista y en el orden sociocultural, al mestizaje, ambos entendidos como fórmulas conciliadoras que harían desaparecer las diferencias sociales y raciales para dar a Cuba una nueva orientación y nuevas respuestas en torno al proyecto de descolonización que 
la Revolución traía consigo (Leclercq 2004: 11). En este momento crucial en el que el país necesitaba homogeneizarse contra los llamados "enemigos políticos", ambos conceptos se convirtieron en un programa nacional ocupando un lugar correlativo al de la noción de cubanidad. De este modo adquirieron la relevancia necesaria para ubicarse por encima de todas las diferencias raciales, culturales o económicas y responder, así, a las prerrogativas del pensamiento marxista según las cuales "las particularidades de las minorías nacionales [...] serán incorporadas o absorbidas por los conjuntos nacionales en el futuro, conservándose en calidad de monumentos etnográficos" (466).

Los intelectuales cubanos asumieron un rol preponderante en esa tarea de redefinir la identidad de la nación. Y la literatura "actor más que testigo" al decir de Luis Duno Gottberg (2003: 15) fue hacedora y herramienta al mismo tiempo de esta construcción de la ciudad letrada que “apelando a la conciliación de las diferencias, se constituye a partir de un conflicto y una tensión interna que no alcanza a resolver las contradicciones reales de la sociedad" (27).

Sin embargo Cuba no constituyó, en este sentido, un caso particular o desgajado del resto del continente. Ana Pizarro afirma que fueron los años sesenta un período en el que se impuso, en América Latina, la idea de una "búsqueda de la identidad" la que, aunque décadas más tarde fue cuestionada por ser una opción restrictiva en tanto, como búsqueda, exige la existencia previa de una identidad y, consecuentemente su "revelación", constituyó un motor fundamental para la producción artística en general 
pero, especialmente, para la literaria y ensayística (2004: 22) ${ }^{57}$. Se suscitó entonces un intenso debate a partir de la cuestión estética que puso sobre el tapete polémicas y disidencias en torno a la pregunta sobre quién y de qué manera representaba más "genuinamente" nuestra identidad continental. Dicho de otra manera, se originó una discusión que tuvo como objetivo, y consecuencia, establecer los cánones nacionales y continentales a partir de los cuales se definiría la "legítima" literatura latinoamericana.

En relación con la elección poética, varios de los exponentes más importantes de la narrativa de la segunda mitad del siglo XX -Gabriel García Márquez, Alejo Carpentier, José Lezama Lima - han coincidido en asumir el barroco, y su correlativo contemporáneo, el neobarroco, como la forma de expresión artística más adecuada para intentar dar cuenta acerca de qué es ser latinoamericano. Éste ha sido, y aún lo es, un objeto de estudio por demás controvertido, por lo que fue abordado desde múltiples y hasta contradictorias perspectivas aunque podría afirmarse que existen en la crítica de arte, tres posturas fundamentales en los estudios sobre el

\footnotetext{
${ }^{57}$ Una de las propuestas que más adeptos consiguió fue la de la "unidad en la diversidad" que inauguró Ángel Rama y continuó Ana Pizarro. Esta propuesta fue proclamada en la "Declaración de Génova" (enero de 1965) - y publicada por Casa de las Américas $\mathrm{N}^{\circ}$ 30 - como resultado de un encuentro de intelectuales latinoamericanos que, bajo el auspicio de un organismo cultural con sede en esa ciudad - el Columbianum - se reunieron para debatir en torno a problemáticas concernientes a América Latina, desde perspectivas que el mismo Rama calificó como pluriideológicas (Gilman 2003: 112). Más tarde, fue retomada por Pizarro - discípula y en gran medida continuadora del trabajo de Rama - principalmente en el texto La literatura latinoamericana como proceso (1985). En la Introducción de esta obra, Pizarro reflexiona acerca de las dificultades de construir una "historia literaria latinoamericana" en tanto está en cuestionamiento el corpus mismo de semejante trabajo. Se pregunta Pizarro por el estatuto de la producción de los jesuitas, las de los viajeros o las de los exiliados, entre otros, pero lo que no es puesto en discusión son los parámetros según los cuales se determina qué es o no literatura. Dicho de otra manera, Pizarro, y en este mismo sentido también Rama, dejan entrever en este planteo de la unidad/ diversidad cierta perspectiva europeizante que los obliga a pensar que todo lo que no es homogéneo es diverso (divergente) con respecto a, en este caso, la cultura metropolitana.
} 
barroco $^{58}$. A saber: una que enfatiza el referente histórico y sociológico; otra que defiende lo tipológico intemporal y una tercera que busca en la evolución de la forma claves para la comprensión del fenómeno (Bustillo 1996: 41).

La primera de estas posturas entiende el barroco como respuesta a la crisis que sumió al hombre en un estado de inestabilidad permanente y que tuvo que ver, para autores como Arnold Hauser, con el llamado "giro copernicano". Este desplazamiento de la Tierra desde el centro hacia la periferia del sistema cosmológico, propuesto por Nicolás Copérnico en 1543, implicó echar por tierra tanto el geocentrismo como el antropocentrismo, ambos propios del período renacentista, y sumergir al sujeto en una condición de profundo desequilibrio social y personal en el que Dios y la palabra representativa son objeto de búsqueda persistente. En este orden de cosas, Severo Sarduy en "Barroco y Neobarroco" (1972) y "Barroco" (1974) se distancia de Hauser proponiendo a Johannes Kepler y no a Copérnico como el verdadero revolucionario del conocimiento cosmológico ya que éste último mantiene una visión concéntrica del sistema planetario mientras que Kepler plantea que la figura que describen los planetas alrededor del Sol es la elipse y no el círculo. De esta manera, en lugar de desplazamiento lo que se produce es un "descentramiento", es decir, un desdoblamiento del centro por medio del cual un lado es iluminado mientras que el otro permanece en la oscuridad aunque tan operante como su doble visible.

\footnotetext{
${ }^{58}$ Para un estudio detallado de los distintos abordajes sobre el barroco y el neobarroco en el siglo XX ver Rincón, Carlos. Mapas y pliegues. Ensayos de cartografía cultural y de lectura del Neobarroco. Colombia: Colcultura, 1996.
} 
Por su parte, Antonio Maravall toma esta idea de crisis y la desarrolla teniendo en cuenta los aspectos sociales y económicos de la época. Para este autor, el barroco es una respuesta al "desajuste de una sociedad en cuyo interior se han desarrollado fuerzas que la impulsan a cambiar y pugnan con otras más poderosas cuyo objetivo es la conservación" (1981: 69). Se instituye, entonces, como "cultura dirigida", como "operación social tendente a contener las fuerzas dispersadoras que amenazaban con descomponer el orden tradicional" (71) negando, de este modo, lo que para Fernando Rodríguez de la Flor es la peculiaridad de la cultura barroca hispana, es decir "la capacidad manifiesta de su sistema expresivo para marchar en la dirección contraria a cualquier fin establecido" (2002: 19). En este sentido, F. R. de la Flor realiza una lectura por demás interesante, en mi opinión, ya que, si bien reconoce el aporte fundamental que significaron los trabajos de Maravall al estudio del barroco, no duda en criticarlos, de manera que su contribución, lejos de repetir lo ya dicho, implica una contribución enriquecedora del campo problemático. De la Flor afirma que "lo que con más energía y singularidad muestra una cultura como la española del Seiscientos es la apertura a representar una pulsión de muerte y un principio de ir más allá de todas las determinaciones, entre ellas las de la misma razón" (19), por lo que su propuesta consiste en recuperar un aspecto que, según él, ha sido soslayado por Maravall debido a su visión progresista de la humanidad. Esto es, reintroducir en el discurso del barroco español esta visión negativa, "todo lo que manifieste en el terreno de la 
producción simbólica una energía entrópica -a la que bien podríamos denominar, con palabra de época, destrudo- $(20)^{59}$.

A la negación de la posibilidad subversiva del barroco, nuevamente Sarduy repara contraponiéndole un barroco actual como reflejo estructural de la inarmonía y de la ruptura de la homogeneidad. Un neobarroco que no constituye propiamente una continuación del barroco del siglo XVII sino la reapropiación contextualizada de algunos de sus elementos y, consecuentemente, una nueva mirada en torno a las circunstancias en las que está inmerso y por las que se asume como una postura crítica, política ${ }^{60}$.

En contrapartida con estas perspectivas, la postura que desarrolla Eugenio D’Ors en Lo barroco (1944) se opone a los conceptos de estilo y de época ya que considera al barroco como una constante de la naturaleza y el espíritu humano, una esencia universal regida por el ritmo cíclico del eterno retorno y presente en diferentes manifestaciones (Guerrero 1987: 14). La caracterización que hace D’Ors sobre el barroco como expresión en la que

\footnotetext{
${ }^{59}$ Retomando a Blanchot, Michel Foucault comienza el capítulo "El lenguaje al infinito" —publicado en Tel Quel en 1963 y luego reeditado en el libro De lenguaje y literaturaafirmando "Escribir para no morir [...] es una tarea tan vieja como el habla" (1996: 143). De esta manera introduce una problemática estrechamente vinculada con el barroco que es la relación entre el lenguaje y la muerte por la cual el lenguaje, ante la muerte "prosigue con una aceleración extrema, pero también vuelve a comenzar, se cuenta a sí mismo, descubre el relato del relato y aquella encajadura que bien podría no acabar nunca. El lenguaje, sobre la línea de la muerte, se refleja: halla en sí como un espejo; y para detener esa muerte que va a detenerlo, sólo tiene un poder: el de alumbrar en sí mismo su propia imagen dentro de un juego de lunas que no tiene límites" (144).

${ }^{60} \mathrm{Si}$ bien cercanos en varios aspectos, una postura contraria a la de Sarduy en este sentido es la lectura que Jacques Lacan realiza en su Seminario 20 "Aún” ya que, de acuerdo con F. R. de la Flor, es una "“."Deshistorización” total del concepto de lo barroco” (18).

Otro abordaje más reciente que, aunque de una manera diferente, también constituye una mirada contrapuesta a la del escritor cubano es la propuesta de Omar Calabrese quien, en La era neobarroca, define al neobarroco como un "'aire de los tiempos" que invade muchos fenómenos culturales de hoy en todos los campos del saber, haciéndolos familiares los unos a los otros y que, al mismo tiempo, los diferencia de todos los otros fenómenos culturales de un pasado más o menos reciente (1999: 12). Considero que la imprecisión y ambigüedad de este fragmento son un ejemplo de los muchos que se pueden encontrar en el libro. En mi opinión, teorizaciones de este tipo tienen la desventajosa particularidad de crear conceptos "etiquetas" que sirven para adjetivar mucho y explicar poco porque, entre otras cosas, despojan a las palabras de su inevitable significación política.
} 
las líneas se entrecruzan, se tuercen o se quiebran, los volúmenes se animan por los efectos de contraste, el movimiento se opone al equilibrio, la armonía y la estabilidad y las fuerzas de la pasión prevalecen sobre las de la disciplina es lo que le permite encontrar expresiones en todas las fases históricas e instituirlo como un intérprete eterno de aquello que las reglas y la mesura no son capaces de expresar suficientemente. "Siempre que encontramos reunidas en un solo gesto varias intenciones contradictorias, el resultado estilístico pertenece a la categoría del Barroco" expresa D`Ors (1964: 29) pero su caracterización es tan vaga y su afirmación tan amplia que no se puede menos que afirmar que su teoría es indiscutible pero también inaceptable en tanto se sustenta en la simplificación estética y la despreocupación socio- histórica y política.

Finalmente, la perspectiva de Heinrich Wölfflin (1888) centra su atención sobre las categorías formales y su fundamento psicológico en tanto analiza el barroco como movimiento de masas pesadas que se aparece como un impulso ascendente y que contrasta con la sensación de ser arrastrado hacia abajo (Hatzfeld 1964: 13). Su mayor interés consiste en explicar las transformaciones que sufre este arte en contraposición con el renacentista. Para eso, en el año 1915 amplía su teoría y establece cinco grandes líneas de cambio: de lo lineal a lo pictórico, de lo superficial a la profundidad, de la forma cerrada a la forma abierta, de la multiplicidad a la unidad, de la claridad a la relativa oscuridad (Bustillo 56) por lo que fundamenta su análisis en un punto de vista pictórico que "somete la multiplicidad de sus elementos a una idea central, con una visión sin límites y una relativa 
oscuridad que evita los detalles y los perfiles agudos, siendo al mismo tiempo un estilo que, en lugar de revelar su arte, lo esconde" (Hatzfeld 15).

La recepción del barroco en América no constituye un capítulo diferente de su historia europea ya que, si bien es una expresión estética que ha sido adoptada en múltiples oportunidades y de diversas maneras, los críticos han demorado casi hasta mediados del siglo $\mathrm{XX}$ en otorgarle el lugar de reconocimiento que merece, operación que llevaron adelante, en una primera instancia y en lo que respecta al ámbito literario, Pedro Henríquez Ureña y Mariano Picón Salas, y Emilio Carilla posteriormente ${ }^{61}$.

Pero es a partir de los años sesenta como "respuesta a la necesidad de hallar un nuevo paradigma interpretativo que pudiese hacer frente a las innovaciones técnicas de la ficción narrativa en aquel período del boom" (Guerrero 12) cuando se pone en boga con mayor énfasis la discusión en torno al fenómeno del barroco en América. Algunos autores, como Bustillo, atribuyen este nuevo acercamiento a la problemática del barroco actual como una deriva de las teorías que conciben esta estética como una constante histórica. Otros, en cambio ven en este nuevo abordaje un "debate sordo" entre las dos teorías - esencialistas y evolutivos - que da lugar a dos tesis contrapuestas por medio de las cuales se intenta explicar este fenómeno (Guerrero 13-14). En mi opinión, es esta última perspectiva, más amplia y más compleja, la que nos permite revisarlo en toda su riqueza ya que incluye autores y pensamientos de suma relevancia para el tema pero, a su vez, con grandes diferencias entre sí, tales como José Lezama Lima, Alejo

\footnotetext{
${ }^{61}$ Para un detalle más exhaustivo de los abordajes del barroco en América ver Roggiano, Alberto "Acerca de dos barrocos: el de España y el de América" en Actas del XVII Congreso de Instituto Internacional de Literatura Iberoamericana. Madrid: Ediciones Cultura Hispánica del Centro Iberoamericano de Cooperación, 1978.
} 
Carpentier y Severo Sarduy por mencionar sólo los estrechamente relacionados con el ámbito cultural cubano.

Un debate de suma importancia que se suscitó en las últimas décadas del siglo XX en torno al barroco latinoamericano es el que tuvo como eje la función social e ideológica que esta expresión artística asumió en América en sus distintos momentos y que se resume, fundamentalmente, en dos posturas contrapuestas: la que entiende el barroco americano como transplante o copia del español puesto al servicio de la ideología imperialista, por un lado, y la que juzga que esta manifestación artística tuvo en América sus propios representantes, quienes no sólo tuvieron la importancia de los europeos sino que, además -y esto, considero, es lo más relevante- desarrollaron su arte como una respuesta contra-hegemónica a esa ideología.

Uno de los trabajos precursores en relación con la primera de estas posturas es el que corresponde a Leonardo Acosta: El Barroco de Indias y otros ensayos (1984). En esta obra Acosta plantea un análisis de la problemática colonial en términos económicos que le permite afirmar que mientras que las colonias tuvieron un papel asignado por el cual, gracias al trabajo de indios y negros, se convirtieron en meros productores de materia prima, la metrópoli exportó productos elaborados, entre los que se cuentan la cultura y la ideología (12) y que funcionaron, en este último caso, como instrumentos de justificación de la dominación y reeducación de los nativos dentro de esta lógica "civilizadora" (13). El barroco, como arte dominante que fuera introducido en América una vez terminada la conquista, fue uno de estos instrumentos cuya finalidad fue, según Acosta, "mitificar y 
eternizar esa conquista, darle validez, no ya legal, lo cual había sido labor de

los teólogos y juristas, sino artística, cultural” (24). Se constituyó entonces, en una cultura con doble propósito: por un lado, alimentar culturalmente a los españoles para que no se desvíen de la ortodoxia; por el otro, imponerse represivamente sobre los pueblos indígenas y africanos $(24)^{62}$.

En cuanto a la segunda postura, uno de sus representantes más reconocidos es el propio Lezama Lima quien en La expresión americana (1957) contrapone a la idea del barroco como "arte de la Contrarreforma" el barroco americano como "arte de la contraconquista" dando a las formas artísticas un estatus que las hace vehículo para manifestaciones ideológicas contrapuestas y que, aún más, excede el propio campo de lo artístico dando lugar a un barroco que se amplía a "muebles para la vivienda, formas de vida y de curiosidad, misticismo que se ciñe a nuevos módulos para la plegaria, maneras del saboreo y del tratamiento de los manjares [...]" $(91)^{63}$.

62 En el mismo sentido, un ejemplo más actual es el artículo "Sobre Góngora y el gongorismo colonial" en el que John Beverly analiza la vinculación entre el gongorismo como fenómeno estético y la estructura del poder colonial con el fin de determinar si es ésta una relación de disidencia o conformidad (1989: 34). Este abordaje lo lleva a concluir que el empleo de algunos recursos típicamente gongorinos en la poesía colonial americana permitió naturalizar y conservar las relaciones de poder establecidas otorgándole al colonizador el derecho de pensar que su situación de privilegio es un fenómeno providencial propio de un espacio social armónico y utópico y que toda rebelión o disidencia se descalificaría automáticamente como producto de fuerzas del mal que amenazan con quebrantar este orden (43). De este modo, según Beverly, el gongorismo llegó a América como discurso estético oficializante de la Colonia por lo que constituye "una nueva modalidad de colonización [...]. Es una técnica, un arte de ingenio, un ejercicio que puede servir como forma de adoctrinamiento en las nuevas prácticas ideológicas elaboradas por y dentro del aparato burocrático de los Virreinatos para mantener la hegemonía española en América" (43). Visto así, la polémica que Beverly entabla con Sarduy es obvia y explícita: "donde Sarduy propone un "barroco de revolución" [...] sería más verosímil hablar, en el caso particular del gongorismo colonial, de un barroco de enmascaramiento, enajenación, represión" (43).

${ }^{63}$ También en este sentido y retomando la tesis de Lezama Lima, Gonzalo Celorio afirma: "La hibridez, la mixtura, la simbiosis hacen del barroco americano un arte bizarro, fantasioso, colorido, popular que lejos de reflejar la sumisión propuesta por Acosta es signo vigoroso de la originalidad americana" (2001: 88).

Sarduy, en el ensayo "El heredero" reconoce a Lezama Lima como el fundador del neobarroco latinoamericano en tanto establece una equivalencia entre el gesto lezamesco 
Para Lezama, entonces, el barroco es el "americano señor barroco, auténtico primer instalado en lo nuestro" que aparece no como herramienta de la dominación sino, por el contrario, "cuando ya se han alejado del tumulto de la conquista y la parcelación del paisaje del colonizador" (92). Con este sentido, toma como ejemplos que enarbola y canoniza a las figuras del quechua Kondori, y del mulato Aleijadinho. El primero de ellos inserta y reelabora la tradición incaica en las "masas pétreas de las edificaciones de la Compañía”; el segundo simboliza la rebelión artística del negro. Ambos constituyen la prueba fehaciente de que "El barroco como estilo ha logrado ya en la América del siglo XVIII, el pacto de familia del indio Kondori, y el triunfo prodigioso del Aleijadinho, que prepara ya la rebelión del próximo siglo, es la prueba de que se está maduro ya para una ruptura” (117). Esta constatación es la que le permite establecer una línea de continuidad con lo que él mismo denomina la gesta de José Martí y que es, ni más ni menos, que la adquisición de un lenguaje que demostraba que la nación había adquirido una forma ${ }^{64}$.

que implica su pasión por la eficacia del signo con el gesto fundador del Concilio de Trento que consiste en el signo eficaz que pone la operatividad de los sacramentos en el hecho mismo de su ejecución: "El signo literario también recupera en Lezama su eficacia tridentina, ya que es el único, entre nosotros, que funciona por el hecho mismo de su ejecución [se trata, en Paradiso] de la puesta en escena, o de la ejecución ritual, de un signo particular, ése que por su densidad fonética, su concentración y su drama funciona por sí solo, por el simple hecho de su enunciación" (1999 [1988]: 1406-7).

En este sentido, María Guadalupe Silva, en "Severo Sarduy, un heredero en el exilio" (2008), afirma que la teoría sarduyana sobre la cultura contemporánea expresada como una época "neobarroca" "rinde tributo a las interrogaciones sobre el ser nacional" (279) por lo que, en tanto es una teoría que se sustenta en la tesis propuesta algunos años antes por José Lezama Lima, constituye para Sarduy una inserción en un juego de tensiones mediante el cual arma su propio linaje el cual "hunde sus raíces en lo más profundo de la historia insular" (280).

64 Por su parte, Mabel Moraña, en el ámbito de la teoría cultural, también asume una postura contrapuesta a la de Beverly y Acosta. Si bien reconoce que existen en las manifestaciones artísticas del Barroco de Indias ciertas tendencias que reproducen el orden establecido, afirma que hay una respuesta social diferenciada, que no es más que el reverso del fenómeno de imposición verticalizada de los discursos dominantes, generada por los sectores subalternos como formas alternativas tendientes a impugnar el discurso 
En otro sentido, una postura de suma relevancia en relación con el tema es la que asume Alejo Carpentier. En la conferencia realizada en Caracas en 1975, y luego publicada con el título "Lo barroco y lo real maravilloso" en Tientos y diferencias, Carpentier afirmaba que "El barroquismo tiene que verse, de acuerdo con Eugenio D’Ors [...] como una constante humana" (1987: 105). Esta aseveración, lejos de ser sólo una declaración poética, encierra una propuesta cultural y política que adquirirá trascendencia insoslayable tanto por su magnitud como por la del lugar que ocupa Carpentier en el campo intelectual latinoamericano ya que es esta atemporalidad, producto de la repetición cíclica en los más variados espacios, lo que le permite asumir la teoría dorsiana como propia y establecer una correspondencia directa entre barroco y América Latina. Pero la atemporalidad no sólo implica repetición sino, también, acumulación, superposición de tiempos, sincretismo. “¿Por qué América Latina es la tierra de elección del barroco?" se pregunta Carpentier. "Porque toda simbiosis,

hegemónico y los principios de legitimación sobre los que se sostiene. Esta respuesta social es lo que Moraña considera el proceso de emergencia de la conciencia criolla.

$\mathrm{Si}$ es cierto que el gongorismo constituyó, en las manos de los jesuitas, un pesado instrumento pedagógico que sirvió para alejar a los niños de su realidad inmediata y sumergirlos en la patria metropolitana también es cierto que "lejos de ser en todos los casos la lengua muerta del poder imperial, dio a muchos intelectuales del barroco indiano un motivo de lucimiento y autoafirmación actuando, paradójicamente, como pretexto en el proceso de conformación de la identidad cultural hispanoamericana”. Para Moraña, entonces, barroco y conciencia criolla son estructuras culturales e ideológicas que dialogan y la literatura una de las formas en que mejor se expresan.

Si bien esta manera de entender el barroco de Indias parece acercar a Moraña a la postura que defiende Sarduy, curiosamente, cuando enuncia los problemas en los estudios sobre el barroco dirige una de sus críticas más fuertes pero, en mi opinión, menos fundamentadas, a los trabajos del cubano. En este sentido afirma que las reflexiones de Lezama Lima, Carpentier y Sarduy constituyen "un rótulo vagamente asociado con el "sistema de preferencias" temáticas y estilísticas que el Barroco formalizó en su momento" con lo cual, considera "el procedimiento trivializa y en gran medida tiende a la desemantización del término". Más adelante agrega que "Otra variante de la cuestión barroca es la que ilustra, por ejemplo, el delirio crítico de Severo Sarduy, que se lanza a una interpretación libre de lo que denomina el "campo simbólico del barroco"”" [Las itálicas son mías]. En mi opinión, si la segunda afirmación carece de una explicación que fundamente semejante tesis, la primera adolece de equiparar a tres intelectuales cuya obra, ya sea teórica o artística, es significativamente diferente. 
todo mestizaje, engendra barroquismo" (112). Es decir, allí donde "haya en un solo gesto varias intenciones contradictorias" habrá barroco y para Carpentier es ésta una característica esencial, no circunstancial, de América: "Nuestro mundo es barroco por la arquitectura [...] por el enrevesamiento y la complejidad de su naturaleza y su vegetación, por la policromía de cuanto nos circunda, por la pulsión telúrica de los fenómenos a que estamos todavía sometidos" (116). El barroco es intrínseco a América Latina, abarca todos los espectros, desde la naturaleza a la historia, el arte, la cultura y, por todo esto, la identidad ${ }^{65}$. Nos define, nos explica, nos limita, nos excede. Nos constituye como americanos y crea en nosotros la conciencia de "ser otra cosa, de ser una cosa nueva [...] de ser un criollo; y el espíritu criollo de por sí es un espíritu barroco" $(112)^{66}$.

\footnotetext{
${ }^{65}$ Silva señala con acierto que la necesidad de Carpentier de nombrar lo latinoamericano mediante el estilo barroco para insertarlo en lo universal lo acerca a las poéticas realistas por lo que compara las divergencias que se presentan entre este autor y Sarduy con los debates de Roland Barthes con Sartre en El grado cero de la escritura (1953). En este sentido afirma: "El punto central de aquella discusión pasaba por establecer cuál era el lugar del compromiso en la tarea literaria, problema al que Barthes respondía diciendo que dicho lugar no radica en el plano del mensaje, sino que se juega en el orden más sutil de la escritura" (2008: 283).

${ }^{66}$ Es este espíritu criollo y la conciencia de ser una cosa nueva, la superposición de tiempos y la exhuberancia de las riquezas y los personajes lo que se transmite en Concierto barroco (1966) a través de una trama en la que un indiano parte de México hacia Europa buscando sus orígenes, su identidad. Pero su itinerario no es lineal ni progresivo, por el contrario, está inscripto en la circularidad de los tiempos que superpone acontecimientos, actores y espacios de distintas historias en un sincretismo armónico que reúne la música clásica con los instrumentos y las melodías de la cultura popular, lo europeo con lo americano y lo afro, los hombres de la nobleza con esclavos y prostitutas, blancos, negros y mulatos. Y todo esto puesto en escena a través de un lenguaje proliferante y desmesurado que despliega un sinnúmero de estrategias lingüísticas y discursivas para crear este concierto que es barroco -entre otras cosas, porque así ha dado en llamarlo su autor- en la misma acepción dorsiana del término, es decir, un barroco simbiótico, mestizo. Esta identidad está determinada por el enrevesamiento y la exhuberancia de una naturaleza generosa frente a la ausencia velada de una Historia trágica, dolorosa - la de los innumerables actos de violencia que azotan a América Latina desde la Conquista hasta ahora- que apenas se deja contar como la historia personal de quien se encuentra a sí mismo en la fusión armoniosa de una amplísima variedad de componentes que conviven cotidianamente en una misma cultura y un mismo sujeto. Una identidad, finalmente, que no cuestiona ni impugna este estado de cosas sino que lo celebra porque, al fin de cuentas, la reconciliación (¿a costa del olvido?) parece ser la propuesta válida para este nuevo intento de ser otra cosa, una cosa nueva que bien puede ser un criollo, un continente o una nación, si es ése el proyecto político que se pretende
} 
En resumidas cuentas, independientemente de cómo se lo haya visto, en América Latina el barroco constituye la expresión estética privilegiada por gran número de escritores, críticos y artistas para preguntarse y/o responderse acerca de la latinoamericanidad. En otras palabras, ha sido, y es, forma o esencia del ser latinoamericano, expresión o sentido, manifestación artística o constante cíclica y, en todos los casos, objeto de reflexión y discusión a través del cual se dirime no sólo cómo debe expresarse nuestro arte sino, lo que quizá sea más importante, quiénes y cómo somos, cuál es nuestro lugar y cuál el que en verdad ocupamos.

En este sentido, el abordaje que Irlemar Chiampi realiza en su libro Barroco y Modernidad (2000) suscita un interés especial en tanto se propone examinar la manera en que algunos escritores latinoamericanos reciclaron ciertos rasgos de estilo característicos del barroco con el fin de producir el efecto neobarroco (9). Con este objetivo, Chiampi organiza su análisis en torno a los ejes modernidad/posmodernidad a partir de los cuales examina y distingue este reciclaje entre dos grandes propuestas. La primera retoma lo barroco como un factor de identidad y se corresponde con el auge de la narrativa del boom, cuando la novela recupera los orígenes barrocos en su lenguaje. La segunda propuesta se ubica en el contexto de un nuevo orden cultural que descree de los Grandes Relatos y toma el neobarroco como un instrumento de crítica del proyecto iluminista (10) en tanto, al decir de Chiampi, "no inscribe lo arcaico del barroco sino para alegorizar la disonancia de la modernidad y la cultura de América Latina” (29).

defender o construir. Bien puede ser el indiano, América Latina o Cuba en su proceso de consolidación nacional después de la Revolución. 
En este contexto, Severo Sarduy es uno de los primeros en asumir la necesidad de teorizar acerca del neobarroco como una forma, fuera de sus propias producciones poéticas y narrativas, de circunscribir esta problemática que es especialmente importante no sólo en el ámbito de América Latina en general, sino también, particularmente en $\mathrm{Cuba}^{67}$. El concepto de retombée por medio del cual introduce una relación como de eco entre las teorías cosmológicas y las manifestaciones artísticas es una clave por medio de la cual en los ensayos mencionados introduce una mirada cultural, socio-histórica y epistemológica que aún no había sido tenida en cuenta para analizar el fenómeno en su conjunto. Pero más importante que esto quizás sea que esta propuesta asume como condición central la puesta en crisis de los paradigmas totalizadores $\mathrm{e}$ institucionalizados de la Modernidad lo que trasciende la mera perspectiva teórico- poética y se instituye en una postura que se enmarca en las problemáticas de su tiempo y su espacio y, por lo mismo, se configura en una enunciación política que amplía, complejiza y asume actuales y disímiles aspectos.

El abordaje histórico por el cual se le devuelve al barroco el carácter de "concepto de época" es lo que permite a Sarduy tomarlo como una

\footnotetext{
${ }^{67}$ En Argentina, es Néstor Perlongher uno de los autores en que menos se ha dudado en relacionar con la estética del neobarroco, sólo que en este caso, tal como afirma María Alejandra Minelli "la emergencia de "exceso tropical" en el mesurado Río de La Plata no tarda en acentuar su exabrupto por medio de la transmutación del esplendor barroco en una "poética del enchastre"” (2006: 78) que constituye el neobarroso. Entre muchos otros procedimientos que tienen como finalidad desestabilizar la escritura, se destaca la enunciación femenina como modo de resaltar la movilidad de las identidades (79) por lo que, haciendo fluir el discurso intelectual por los "devenires femeninos" que llevan a un primer plano la cuestión de la corporalidad, antes escasamente abordada, Perlongher traza un registro poético-político en contra del discurso patriarcal de la tradición literaria y los conceptos-mitos de la gramática oficial (85). De esta manera, mediante una estrategia neobarroca/sa se conforma una zona, un borde, en el que el canon establecido es puesto en fuga.
} 
noción operativa y, a partir de esto, hacer las correspondientes distinciones entre el barroco clásico y el neobarroco de modo de circunscribir los fenómenos a una funcionalidad más instrumental que lo preserve de constituirse en una "etiqueta" contenedora de los más incongruentes y disparatados significados:

más que ampliar [...] el concepto de barroco, nos interesaría, al contrario, restringirlo, reducirlo a un esquema operatorio preciso, que no dejara intersticio, que no permitiera el abuso o desenfado terminológico de que esta noción ha sufrido recientemente [...] sino que codificara, en la medida de lo posible, la pertinencia de su aplicación al arte latinoamericano actual (Sarduy 1999 [1972]: 1386).

Si como resonancia del giro copernicano y de la formulación elíptica de las órbitas planetarias de Kepler Sarduy explica el surgimiento del barroco clásico, es a partir de las teorías cosmológicas actuales -el Big Bang y el Steady State- como fundamenta el fenómeno del neobarroco ya que, si las dos primeras teorías generaron un significativo desplazamiento del centro, primero, y un descentramiento después, son éstas últimas las que generan la pérdida de ese centro ${ }^{68}$. Esto constituye, entonces, una diferencia

\footnotetext{
${ }^{68}$ Leonor de Ulloa analiza las primeras cuatro novelas de Sarduy en función de sus teorías cosmológicas sobre el barroco en el artículo "Signos en rotación en el neobarroco pictórico de Severo Sarduy". Según Ulloa, Gestos se caracteriza por su valencia dispersiva producida por una detonación que dará lugar en sus obras posteriores al socavamiento del nivel referencial mientras que De donde son los cantantes ostenta una estructura fragmentada a raíz de que la explosión que aquí se produce es mucho más experimental que en la novela anterior (1989:103). Por su parte, afirma en relación con Cobra que: "el hilado narrativo está totalmente fragmentado, como lo está la relación causa-efecto. [...] El mismo personaje Cobra es también un signo escindido semejante a las parejas de estrellas en estado decadente y sin centro nuclear" (104). Finalmente interpreta que "Maitreya podría ser la obra del "Steady State", en cuanto es un texto en conjugación lenta y constante de sus partes que repetitivamente se aniquilan y renacen como el Buda que le da nombre. Ese estado repetitivo de la obra [...] corresponde a una de las características del "Steady State", o sea, del universo en estado continuo de renovación de materia, que se crea y destruye perpetuamente para producir un cosmos sin principio ni fin definidos" (106).

Me propuse, al reseñar este trabajo, reproducir el lenguaje utilizado por Ulloa porque considero que es importante notar cómo esta crítica se apropia del lenguaje sarduyano para realizar su análisis de las obras. Esta es una característica que se ha dado en no pocas oportunidades en relación con la escritura de Sarduy. Me refiero, concretamente, a la aplicación directa de los términos y nociones teorizados por el cubano para interpretar su obra ficcional. En mi opinión, si bien no se puede considerar que sean aportes erróneos,
} 
fundamental que permite oponer el barroco europeo y el primer barroco colonial latinoamericano al neobarroco. En tanto los primeros se instauran como imágenes de un universo móvil y descentrado pero aún armónico, porque se funda en torno a un logos exterior - el dios jesuita y su metáfora terrestre, el rey - que lo organiza y lo precede, el neobarroco o barroco actual "refleja estructuralmente la inarmonía, la ruptura de la homogeneidad, del logos en tanto que absoluto, la carencia que constituye nuestro fundamento epistémico" (1403).

Para entenderlo de este modo, Sarduy hace operar, en la configuración teórica del neobarroco, los conceptos de supresión y represión, propios de las teorías lacanianas, en consonancia con elementos de la retórica artística ${ }^{69}$. Estos últimos enfatizan y otorgan especial relevancia a la artificialización, mecanismo que no sólo constituye un eje central de su teoría sino que, además, impugna la teoría dorsiana, retomada por Carpentier.

"Apoteosis del artificio, la ironía y la irrisión de la naturaleza" (1387) la estética del barroco adopta, según Sarduy, tres mecanismos lingüísticos fundamentales por medio de los cuales se concreta la mencionada artificialización: la sustitución, la proliferación y la condensación a las que, por definición, identifica, en el caso de las dos primeras, con la metáfora y la metonimia, respectivamente, tal como fueron entendidas por Lacan en sus trabajos sobre la estructuración del sujeto en el lenguaje. La sustitución es el procedimiento por el cual el significante ha

este apegamiento a la teoría del escritor impide que los trabajos en cuestión asuman vuelo propio por lo que pierden en riqueza y creatividad personal.

${ }^{69}$ Ver capítulo I. 
sido escamoteado y sustituido por otro totalmente alejado semánticamente de él. Esto instituye una falla entre lo nombrante y lo nombrado que genera el surgimiento de otro nombrante, es decir, la metáfora (1388). De este modo, y en tanto la metáfora se desarrolla en el plano del Inconsciente, es posible identificarla con el mecanismo de la represión, con la organización de la carencia. Ésta pone en funcionamiento una acción de tipo metonímico que implica la fuga indefinida de un objeto de pulsión que se confunde con la metáfora en la medida en que deja entrever un regreso de lo reprimido a través del síntoma (1235).

La proliferación, por su parte, es el procedimiento por el cual es obliterado el significante de un significado dado pero no reemplazándolo por otro sino por una cadena de significantes que progresa metonímicamente y que termina circunscribiendo una órbita a su alrededor de cuya lectura es posible inferirlo (1389): "[la proliferación exige] para hacer adivinable lo que oblitera, para rozar con su perífrasis el significante excluido, expulsado, y dibujar la ausencia que señala, esa traslación, ese recorrido alrededor de lo que falta y cuya falta lo constituye" (1391). De tal modo, la proliferación, análoga a la metonimia, cuya operación gravita precisamente en el desplazamiento del centro de atención, pone en funcionamiento el mecanismo de la elipsis que consiste en el ocultamiento de un término en beneficio de otro. En tal sentido, la elipsis es análoga a la supresión porque es una operación que permanece en el interior del sistema de la conciencia ya que, tanto el significante suprimido como el elidido pasan a la zona del preconsciente y no a la del Inconsciente. 
Metáfora/ sustitución, metonimia/ proliferación/ elipsis constituyen, entonces, elementos fundantes del neobarroco por lo que permiten establecer relaciones con otras áreas del pensamiento contemporáneo. Pero también, porque lo conectan, sin instituir homologaciones simplificadoras de las diferencias históricas, con el barroco clásico en función de las teorizaciones del mismo Sarduy por las cuales, apelando nuevamente al concepto de retombée construye analogías entre la metáfora y la órbita circular de los planetas proclamada por el modelo cosmológico galileano y la elipsis y la órbita elíptica del espacio kepleriano ya que, si la primera constituye un desplazamiento "siempre a igual distancia alrededor de un centro esplendente" (1222), la segunda, en cambio, opera como denegación de un elemento y concentración metonímica de la luz en otro (1231).

Ya en un nivel que abarca la totalidad del texto, Sarduy enfatiza la parodia en tanto espacio de dialogismo y carnavalización, como un procedimiento de especial relevancia que, para el caso de establecer una semiología del barroco latinoamericano, debe tenerse en cuenta a través de elementos como la intertextualidad (cita o reminiscencia) y la intratextualidad (gramas fonéticos, sémicos y sintagmáticos) ${ }^{70}$. Así, el espacio barroco no sólo es de artificio extremo sino, y como consecuencia de esto, es el de la superabundancia y el desperdicio que, en contraposición con el lenguaje económico de la mera función comunicativa "se complace en el suplemento, en la demasía y la pérdida parcial de su objeto. O mejor: en la búsqueda, por definición frustrada, del objeto parcial" (1401).

\footnotetext{
${ }^{70}$ En una entrevista realizada con Roberto González Echevarría Sarduy afirma: "yo parto siempre de la noción del barroco como un fenómeno de intertextualidad, precisamente porque la intertextualidad me permite hacer funcionar otro elemento, a mi juicio, esencial, lo paródico - la práctica paródica, muy visible en Lezama y muy poco visible, y perdóname, en Carpentier" (1972: 42).
} 
Frustración que no implica el abandono del proyecto sino la repetición obsesiva de esa cosa inútil que es el suplemento y que instaura, consecuentemente, un juego erótico, en tanto actividad lúdica que no es más que una parodia de la función de reproducción, pérdida, desperdicio y placer (1402). Dicho de otro modo, el erotismo, análogo a la retórica barroca "se presenta como la ruptura total del nivel denotativo, directo y natural del lenguaje - somático-, como la perversión que implica toda metáfora, toda figura" (1402). El lenguaje barroco, entonces, funciona, según Sarduy, como una amenaza, una parodia de la administración tacaña de la economía burguesa en tanto tiene como única finalidad el derroche, el malgasto en función del placer.

Juego, derroche, exceso, superabundancia y malgasto que no se agotan en los procedimientos hasta aquí mencionados sino que incluyen otros como la anamorfosis, la simulación y el trompe-l' oeil, por mencionar sólo algunos, que constituyen una puesta en escena del "horror al vacío", es decir, un mecanismo que resalta el lenguaje hasta extremos incomparables en menoscabo de otro elemento que queda oscurecido. Lenguaje barroco, vuelto sobre sí mismo, el gran expulsado, en este caso, es el sujeto ya que no está donde se lo busca, es decir, en el centro del discurso que se enuncia y del que sería autor y autoridad, sino bajo el significante elidido al cual cree haber expulsado pero del que, a su vez, se cree expulsado (1237).

Dicho de otra manera, la ruptura de la categoría moderna de sujeto es una de las características fundamentales del neobarroco. Pero también lo es el quiebre de otras categorías relevantes que operan en correlación con ésta, 
tal como son la temporalidad, la Historia, la Literatura, la Identidad ${ }^{71}$. Sin embargo, creo importante aclarar que esto no constituye una analogía con la posmodernidad entendida como fin de -la historia, la cultura, el sujeto-. Por el contrario, hablar de neobarroco implica historizar y reconfigurar una estructura estético-ideológica particular con el fin de utilizarla como herramienta de análisis que permita no sólo caracterizar ciertas manifestaciones artísticas o culturales sino también enmarcarlas en una postura crítico-política determinada.

\footnotetext{
${ }^{71}$ En relación con el aspecto temporal, éste constituye un punto de coincidencia más con el barroco clásico en tanto, tal como lo explica Rodríguez de la Flor, "la flecha direccional" que alumbra siempre las interpretaciones de los historiadores más o menos positivistas es susceptible de ser convertida [...] en la figura epistemológica más compleja de un pliegue del tiempo sobre sí mismo. Siguiendo a Deleuze, de un pliegue barroco" (2002: 34).
} 


\section{3. 1. Cobra: escritura y fetichización}

No hay arriba ni abajo: el mundo se ha concentrado en este rectángulo sereno. Un espacio en el que cabe todo y que no contiene sino aire y unas cuantas imágenes que se disipan.

Severo Sarduy, Cobra

El exilio es también eso: borrar la marca del origen, pasar a lo obscuro donde se vio la luz [...].

Severo Sarduy, "Exiliado de sí mismo"

Juego del lenguaje, desmesura, artificio, lujo parecen ser las características que mejor definen a Cobra (1972), una de las más importantes novelas del cubano Severo Sarduy, razón por la cual la crítica no ha discutido su inclusión en las páginas de la literatura del neobarroco latinoamericano. Más aún, parece haber caído en una especie de trampa barroca: serpiente que se muerde la cola, gran parte de los abordajes anteriores han sucumbido a la tentación de leer la novela teniendo en cuenta solamente los postulados teóricos del autor, desconociendo, de esta manera, la amplia gama de posibilidades interpretativas que la obra sugiere. Estos acercamientos han llevado a conclusiones en las que Cobra sólo tiene importancia en cuanto a su artificialidad, pero sin que se reconozca en ella ningún tipo de profundidad sino es la del lenguaje mismo: "En Cobra el lector se encuentra, pues, con un texto que no intenta decir nada. Más aún, que se propone eludir cualquier significado posible” (Bustillo 1988: 187). 
En este mismo sentido, el artículo "Visión cosmográfica en la obra de Severo Sarduy" de Lourdes Gil e Iraida Iturralde toma como punto de partida un ensayo del propio Sarduy en el que describe el código de lectura de Luis de Góngora como "una lengua compuesta por todos los elementos culturales del Renacimiento" (1991: 337) y enumera las referencias que hacen de esta época un momento de renovación y reinterpretación de la anterior, posicionando al autor español como representativo de este momento particular. Así, Gil e Iturralde construyen un discurso en el que ponen en funcionamiento para Sarduy la misma estrategia que él empleó para con Góngora en tanto consideran el diálogo entre numerosos y disímiles elementos —erotismo, plástica, textos orientales, teatro, componentes culturales occidentales, etc.- como una exaltación postestructuralista del texto que tiene como finalidad entretejer el discurso científico al literario y constituirse, también él en "reflejo y expresión de su época" (337). Concluyen, entonces, que el barroco, en este autor, es la encarnación del concepto científico del Universo debido a que la elipsis kepleriana, - tal como el mismo Sarduy lo explica en su ya clásico ensayo- no sólo deconstruye la idea de un centro único en favor del descentramiento que opone a un foco visible otro igualmente operante pero oculto, subvirtiendo de este modo el orden establecido por el giro copernicano, sino que, y como consecuencia de esto, instaura la elipse como figura retórica por excelencia de la literatura. De ahí que la retombée "donde las palabras o gestos [...] no se rigen $\mathrm{u}$ organizan estructuradamente en torno a sus ejes, sino que se ensanchan, desdoblan y transforman en perenne reflejo de los cuerpos celestes de un Universo oscilante" (339) se transforme 
en la clave para entender el intercambio ecoico que en el discurso sarduyano se lleva a cabo entre la ciencia y el arte. En mi opinión, brillo barroco mediante, la perspectiva con la que las autoras abordan el mundo de Sarduy se deja cegar por la propuesta que el mismo autor plantea en sus textos teóricos, desaprovechando, paradójicamente, la riqueza lingüística e ideológica de la que la obra literaria es depositaria. Lejos de aceptar el desafío de reconstruir elípticamente un sentido que es sólo el eco oscurecido de un centro iluminado, Gil e Iturralde asumen el discurso del cubano precisamente como "reflejo" de su propio pensamiento sin problematizar ni poner en consideración aquellos otros elementos, conscientes o inconscientemente reprimidos, que afloran $\longrightarrow$ deberían hacerlo- en un análisis menos preocupado por las postulaciones sarduyanas y más atento a otras problemáticas.

Contrariamente a esta postura, considero que el lujo y el artificio del lenguaje en Cobra pueden ser leídos, a la luz de otros conceptos teóricos, como estrategias discursivas puestas en funcionamiento no para "eludir cualquier significado posible" sino, por el contrario, para producir nuevos sentidos. Me propongo entonces religar, a partir de un nuevo acercamiento, conceptos tales como fetiche y castración, tomados del psicoanálisis, goce, usado especialmente por Roland Barthes, barroco y neobarroco, entendidos a la manera sarduyana.

Abordar Cobra desde el nivel de la historia permite llegar a diversas lecturas. Para algunos, significa concluir que no pretende decir nada. Para otros, en cambio, implica descubrir cuáles son los núcleos de significación 
alrededor de los cuales se orienta la obra ${ }^{72}$. En este sentido son funcionales a la hora de reconstruir el relato tres momentos claves en la vida de Cobrapersonaje: la castración, la iniciación y la muerte.

Reina del "Teatro Lírico de Muñecas", Cobra se debe enfrentar en cada escena a la ingrata realidad de sus desmesurados pies, no porque en verdad sean demasiado grandes sino porque éstos representan una imperfección mayor: el pene, como signo de lo masculino, que lo/la obliga a travestirse como única forma de simular en lo externo lo que interiormente siente que debería ser. Los intentos repetidos $-\mathrm{y}$ tan desmesurados como los pies mismos- por reducir sus extremidades tienen efectos negativos en relación con su objetivo primordial pero provocan la duplicación de Cobra en un nuevo personaje, Pup, la enana deformada que, para poder ocupar el lugar de su doble en el escenario, debe ser sometida a rigurosos tratamientos cuya finalidad es hacerla crecer. Empecinada en mantener su lugar de privilegio en el teatro, Cobra busca darle una unidad a su contradicción mediante otro procedimiento "científico": la cirugía. "Todo lo que no es textual es castrable" (1999 [1882]: 1296)... por lo que la única salida posible a tal desdoblamiento es la castración, que se lleva a cabo gracias al artificio del Dr. Ktazob. Éste le enseña a Cobra a derivar el dolor hacia su doble - Pup - quien encuentra la muerte en la mesa de cirugía y Cobra recupera así la "unidad" deseada ${ }^{73}$. Se configura, entonces, un complejo

\footnotetext{
72 Tratándose de una obra barroca, toda indagación debe plantearnos no respuestas definitivas, sino nuevos interrogantes. Por esto, en este caso, la idea de núcleo funciona sólo a modo de herramienta de análisis.

${ }^{73}$ René Prieto en "La ambiviolencia en la obra de Severo Sarduy" analiza el nombre de Ktazob como un procedimiento de lectura radial, en la que el tópico del discurso —falo/castración-señala la carencia en tanto está ausente pero aludido, que remite al
} 
proceso de transferencia en el cual opera el diagrama de "necesidaddemanda de amor-deseo", teorizado por Lacan, por el que se establece que "todo proceso erótico significante alude a otro que es parte del sujeto" (Márquez 1991: 304). El final de Pup significa para Cobra liberarse de su Otro, pero también, morir con ella. Así, una vez pasada la castración, nos encontramos con una Cobra que, relacionada con un grupo de motociclistas adeptos al tantrismo, es re-escrita en el orden textual por medio de un ritual de iniciación. En él, Totem, Tundra, Tigre y Escorpión le graban su nombre sobre el cuerpo:

TUNDRA entintó los pinceles.

ESCORPIÓN le trazó en jacket, sobre la espalda, un arco vertical que se abrió en la piel, chorreando, embebido por la felpa, retorciéndose como una serpiente macheteada.

TOTEM, que dormía entre las piedras - dios ebrio sobre un paisaje en miniatura -, se levantó de un salto: de un solo gesto, calígrafo de estilo anguloso, le dibujó el círculo de la adivinación, torcido sobre sí mismo y sin bordes, el aro perfecto. Con un cuño de piedra TIGRE le estampó junto al círculo un sello cuadrado: BR.

TUNDRA le laceró junto al hombro una A (521-522) ${ }^{74}$.

Goce y dolor, ambos inscriptos en el cuerpo mutilado de Cobra constituyen los dos extremos de esta serpiente que se muerde la cola: la escritura relacionada con la identidad es principio, pero en el caso de Cobra también es fin ya que tanto aparece en el nombramiento, en la identificación

significante "castración" ya que por su composición es posible encontrar alusiones al significante falo o a la castración en árabe, italiano y en la lectura fonética del español.

${ }^{74}$ COBRA es un acrónimo de Copenhague, Bruselas y Amsterdam que constituyó un grupo de jóvenes artistas europeos, reunidos hacia 1948, entre cuyos miembros fundadores estaba el danés Asgar Jorn, el pintor holandés Karel Appel y el belga Corneille. El grupo consideraba que el arte se había alejado demasiado de la vida por lo que había perdido su derecho a existir. Propugnaban un regreso a la creación espontánea que se fundamentara en las imágenes de las culturas primitivas de África, en la mitología y el folklore nórdicos, la utilización del color y la forma como lenguaje de expresión más directo. Aunque sólo permanecieron juntos durante tres años, tuvieron un impacto importante en formas artísticas posteriores tales como la Action Painting. 
que da vida al sujeto, como en la muerte. La escritura relacionada con el cuerpo - castración o identificación- se instituye en una paradoja imposible de resolver que implica vivir fuera de sí o morir: descentramiento irreparable del sujeto barroco:

Después vamos a leer en tus huesos.

Con una varilla de metal ardiendo tocaremos cada omóplato:

en las quebraduras los presagios.

Con tinta negra

escribiremos en tu esqueleto mensajes a los descendientes, tu armazón dibujada nos servirá de heraldo: cifras, fechas, quiénes fuimos, qué tiempo nos ha tocado vivir (533).

La Cadillac, biológicamente mujer, lleva adelante un proceso inverso al de Cobra transformándose, también por intermedio del Dr. Ktazob, en hombre. De esta manera, se reafirma la ruptura de la identidad sexual y genérica a través del travestismo y se confirma lo que, en palabras de Roger Lancaster es "un profundo equívoco" (1998: 41) ya que, según este autor, "no es muy correcto afirmar que el travestismo define un espacio de parodia o transgresión. Tampoco es exacto decir que representa un ritual de intensificación" sino que constituye un espacio intermedio en el que las intenciones se mantienen en suspenso sin anularse. Es por esto que, estas prácticas actorales "no pueden nunca limitarse a imitar o simular una 
práctica o una persona o a un tipo original puesto que siempre se exceden respecto de su objeto" (40).

Por el contrario, Judith Butler sí analiza las prácticas del travestismo como una parodia del concepto de una identidad de género original o primaria que cumple la función de poner en evidencia que la identidad sobre la que se articula el género es una imitación sin origen por lo que "Al imitar el género, la travestida manifiesta de forma implícita la estructura imitativa del género en sí, así como su contingencia" [Itálicas en el original] (2007: 268). En un desplazamiento permanente a la manera derridiana se conforma una fluidez de identidades que se abre a la recontextualización y la resignificación en tanto la multiplicación que produce la parodia impide la naturalización de identidades de género esencialistas por parte de la cultura hegemónica.

En mi opinión, considero que si bien ambos autores llegan a conclusiones similares en tanto prevén un espacio múltiple de construcción de identidades de género que no responden a ningún modelo previo, la divergencia que se suscita en relación con la presencia o no de parodia radica en una diferencia implícita en la conceptualización del término. En tanto Lancaster parece adecuarse a la definición que implica a la parodia como inversión en espejo del pre-texto, Butler introduce la idea de desplazamiento, más cercana a la metonimia que a la parodia, con lo cual el efecto de multiplicación y de pérdida del origen es más probable.

De cualquier modo, inversión de la inversión, la Cadillac intenta imitar a Cobra para ocupar su lugar en El Teatro Lírico de Muñecas pero 
este acto de travestimiento la convierte en un sujeto nuevo y, por lo mismo, absolutamente diferente a los otros dos. De este modo, el cuerpo se convierte en una especie de divinidad a la que hay que satisfacer pero también es el soporte de todas las transformaciones, todas las reescrituras, por lo que vive de su artificialidad, de la pulsión hacia el consumo y la exageración fragmentada de algunos de sus atributos ${ }^{75}$.

Este descentramiento de los personajes está representado en el nivel textual mediante diversos procedimientos discursivos. Uno de estos, el más patente quizá, consiste, como en el caso de Pup, en la aparición y desaparición repentina de personajes. Sucede esto, por ejemplo, con la Señora, quien sufre un desdoblamiento similar al de Cobra, por lo que aparece, junto a Pup, una enana igualmente deformada: la Señorita. La diferencia es que el doble de la Señora no desaparece por ningún suceso que guarde cierta lógica narrativa - la muerte, en el caso de Pup- sino por el capricho manifiesto de un artífice omnipresente - narrador o autor- que se entromete en el relato con cierta insolencia ajena al proceso de ficcionalización.

75 Gisela Catanzaro, analizando la configuración del cuerpo durante el proceso de racionalización moderno, afirma: "mediante un continuo e inquebrantable trabajo de aplanadora, el sistema, además de los productos en serie que llamamos "diferencias equivalentes" o falsas, no cesa de producir restos, otros inasimilables e insoportables que, por su misma lógica, es incapaz de comprender como fruto de su cruzada homogeneizadora y espiritualizante. En esta línea de lectura se podría, tal vez, considerar como una especie de "retorno de lo reprimido", el objeto ausente del discurso de la modernidad/ posmodernidad el actual fervor por El físico [...] como una revancha de "lo corporal" que no cuestiona, sin embargo, el carácter homogéneo y para nada disruptivo —en general- de esos cuerpos que parecen volver al primer plano ya vaciados" (2002: 64). Considero que esta línea de pensamiento está en consonancia con un planteo que se hace Sarduy en "La simulación" aunque, en este caso particular, corresponde a una pregunta formulada pero no respondida: "El cuerpo regresa en el momento de crítica, de vacilación de una cultura empeñada durante milenios en ocultar, en obturar "el soporte". [...] Queda por saber si ese exiliado que regresa es el mismo expulsado, si el actor que vuelve a dominar, a veces abusivamente, la escena, a controlar los efectos de la representación, es el mismo a quien ese espacio se vedó, o si se trata sólo de su máscara vaciada, de su doble desacralizado: simple impostura pintarrajeada o verdadera subversión corporal” (1999[1982]: 1303-4). 
Por otra parte, los actantes se metamorfosean adquiriendo nuevos aspectos, características o, en algunos casos, historias, con lo que pierden de este modo su coherencia interna. El ejemplo más claro es el del indio, quien es presentado, en primer lugar, como un artista dedicado a pintar el cuerpo de las bailarinas del "Teatro Lírico de Muñecas"; en segundo lugar, pocos capítulos más adelante, aparece como retratista, encargado de pintar, en un cuadro, la figura de Pup y, finalmente, se transforma en una especie de "mago" que asume la tarea de agrandar a Pup. Las metamorfosis están marcadas, especialmente, por el cambio en la forma de nombrarlo: al principio es el indio, después se llama Eustaquio y más adelante se lo identifica como el pintor, el Maestro y el Transformador. Este procedimiento es puesto en evidencia, una vez más, por la intromisión de la voz del sujeto enunciador en la instancia de la enunciación, esta vez, bajo la forma de una nota a pie de página:

1 Tarado lector: si aun con estas pistas, groseras como postes, no has comprendido que se trata de una metamorfosis del pintor del capítulo anterior -fíjate si no cómo le han quedado los gestos del oficioabandona esta novela y dedícate al templete o a leer las del Boom, que son mucho más claras $(464)^{76}$.

El escamoteo de la identidad de los personajes por medio del cambio de nombre es acompañado por otros tipos de procedimientos, en este caso, correspondientes al nivel oracional, que también tienen como finalidad evitar identificaciones precisas. Por ejemplo: postergación de los sujetos: "El Museo Guggenheim, con sus rampas centrífugas, era menos mareante

\footnotetext{
${ }^{76}$ Esta referencia explícita a la literatura del Boom constituye una mirada crítica que Sarduy seguirá mostrando en sus otras obras aunque ya no de una manera tan directa sino a través del trabajo textual.
} 
que éste, turbio y reducido a un solo estrato, que con su diurno deambular animaba la Alcahueta" (429); uso de perífrasis: "Aparecía el octogenario impersonator de la Ópera de Pekín [...] recibiendo el ramo de flores y la caja de tabaco del viril presidente de una delegación cubana” (430); sinonimia: "Desfilaban las divinidades roncas ante el inventor de alas de mariposa" (432) [Las itálicas son mías] ${ }^{77}$.

La figura del narrador, por su parte, también es un elemento que contribuye a la ruptura de la idea de Sujeto como homogeneidad totalizadora ya que no es posible encontrar en el relato una voz que pueda ser atribuible con precisión a ningún personaje o punto de vista en particular. Por el contrario, el sujeto de la enunciación deviene por momentos en una tercera persona omnisciente que puede cambiar inmediatamente a la primera, singular o plural.

77 Para un análisis más detallado sobre la construcción oracional del texto ver el artículo "Estudio estilístico de Cobra" de Gerardo Vázquez- Ayora. En este trabajo, el autor parte de los supuestos teóricos que le provee la estilística estructural en el marco de lo que él denomina el "estructuralismo actual", esto es la semioestilística, y se propone analizar el idiolecto de la novela sarduyana aplicando un método retrotransformativo en el que sigue el itinerario inverso de las transformaciones para, partiendo desde el discurso, revisar, en primer lugar, la estructura patente, en segunda instancia los enunciados o paradigmas y, por último, las estructuras nucleares o básicas. Este método de trabajo le permite concluir a Vázquez- Ayora que en Cobra se lleva a cabo un procedimiento generativo de incrustación a derecha e izquierda que da como resultado una escritura arabesca y, en consecuencia, una lectura exocéntrica, es decir, que es interrumpida por interpolaciones que no sólo son muy variadas sino que, además, se dan en todos los niveles: en el texto, en el párrafo y en la oración.

Pero, según el análisis de Vázquez- Ayora, este método no da cuenta de la densidad del idiolecto de Severo Sarduy, por lo que es menester no circunscribirse a esta sola descripción. Para ampliar la perspectiva de análisis, entonces, aborda el texto sarduyano bajo el título "Ideología del juego" en el que intenta proyectar el trabajo realizado anteriormente hacia una explicación que contemple aspectos no textuales. Así, concluye que, si bien el centro se ha desplazado hacia el discurso, el idiolecto sarduyano le "arrebata ese primer lugar para dárselo a algo que está fuera del lenguaje [...] percepciones y representaciones que no han estado atadas aún a las nociones y definiciones, a las categorías y mitos, cómodamente instalados en el orden socio-cultural" (1984: 39). Desafortunadamente, esta última perspectiva queda en apenas un esbozo interesante de lo que podría ser un análisis más profundo de la problemática de la escritura sarduyana ya que Vázquez- Ayora retorna casi inmediatamente a su abordaje descriptivo para realizar una enumeración — aunque amplia y con ejemplos claros, escuetamente explicada— de los recursos discursivos utilizados. 
Este cambio repentino provoca, más que distintos puntos de focalización, verdaderas confusiones acerca de quién es el portador de la palabra. De esta manera, enunciador y enunciado quedan desautorizados frente a este dialogismo que somete todo a la más vasta relatividad. Por otra parte, reviste una importancia singular en tanto se lo puede considerar como un punto de enlace entre tres problemáticas fundamentales que aborda la novela: la cuestión del sujeto, ya desarrollada, la historia/ Historia y la Literatura.

Para analizar estos tres controvertidos ejes considero necesario retomar las tres secuencias narrativas abordadas anteriormente -castración, iniciación y muerte- a partir de las cuales es posible arriesgar dos acercamientos diferentes, según se las piense desde la construcción de la historia o desde el punto de vista simbólico.

Teniendo en cuenta el primer aspecto, estas tres secuencias narrativas no constituyen más que hitos en una historia que parece no tener orden ni concierto, es decir, un relato que se define como tal por su apariencia exterior y no por características intrínsecas a él ya que, si bien Cobra presenta todos los elementos paratextuales pertinentes para ser considerada novela - y de hecho, así es como se la considera-, es posible afirmar, por muchas razones, que transgrede ampliamente las condiciones para ser "encuadrada" en este género.

Al igual que la categoría de Sujeto, también la categoría de Historia -representada en el nivel textual por la historia, pequeña, individual, con minúsculas- se encuentra profundamente cuestionada en esta obra. José 
Ortega afirma que es el carácter dinámico de Cobra el que permite explicar la multiplicación de los centros de la narración que se relaciona con el desplazamiento de la función autorial y la autonomía de los distintos segmentos de la obra: "Los materiales en Cobra no se subordinan a un centro, a una composición global, sino a núcleos que van generando múltiples e inéditas ramificaciones" (1984: 46) ${ }^{78}$. En tal sentido, espacio y tiempo, como elementos constitutivos de la estructura de un texto narrativo, son los encargados - entre otros- de otorgar a un relato coherencia interna y unidad y con éstas, un sentido. La ruptura de estos elementos integra, entonces, uno de los recursos más utilizados si se trata de remover los cimientos de una narración. Así se encuentran novelas en las que, por ejemplo, se produce un dislocamiento temporal mediante la evocación adelantada de sucesos que corresponden a un momento posterior. Este tipo de organización textual, si bien causa saltos que exigen un lector más atento

\footnotetext{
${ }^{78}$ José Ortega aborda la temática sarduyana en dos artículos diferentes pero con un objetivo común: demostrar que "en el barroco de Sarduy se sintetiza un desordenado vitalismo con una estructura formalista" (1984: 39 y 1994: 110). Con este propósito, en "Sobre la retórica neobarroca en Cobra, de Severo Sarduy" y "La imaginación neobarroca de Severo Sarduy en Pájaros de la playa" analiza los procedimientos formales que el autor utiliza en cada una de las novelas mencionadas como elementos dispuestos con la intencionalidad de crear un mundo literario signado por la estética neobarroca. Así, conceptos como intertextualidad, elipsis, teatralidad, metáforas, metonimias, comparaciones, artificialidad, entre otros tan representativos del discurso sarduyano como los mencionados aquí, forman parte de una enumeración poco explicada que, si bien es extensa no llega a ser exhaustiva. En ambos artículos, la conclusión de Ortega apunta a la confianza que el autor cubano deposita en la función estética del lenguaje. De tal manera, si Pájaros de la playa se plantea como "el último acto de exorcismo contra el demonio del mal (sida)" (1985: 119) en Cobra, "la función barroca del lenguaje exige un tipo de relación con la realidad" (1984: 48) que, en el caso de Sarduy, es puramente estética y cuyo sentido "lo va instaurando el juego de imágenes, la atracción mutua de palabras y el desplazamiento de los significantes" (ídem). "Estructura formalista" mediante — y ensalzada, diría - el abordaje de Ortega parece olvidarse del otro aspecto enunciado en los primeros renglones de su trabajo. Lo que él denomina "desordenado vitalismo" queda así relegado a un segundo plano en el que se pierde de vista la función excesiva, de desbordamiento, de pluralidad de sentidos que el barroco tiene como proyecto artístico. Esto es, otorgándole una función específica a cada una de las estrategias retóricas utilizadas, Ortega las incluye, en algún sentido, en la lógica economicista de la escritura en la que cada elemento ocupa un lugar determinado acorde a una funcionalidad dada, ignorando, de este modo, la principal riqueza de la literatura neobarroca.
} 
y participativo, no acarrea mayores problemas en el momento de rehacer el hilo narrativo. Esto, en cambio, no sucede en la obra sarduyana analizada, ya que en ella lo que se plantea como procedimientos no son sólo saltos hacia atrás o hacia delante, sino una pulverización de toda idea de tiempo probable. Se puede reconstruir en la novela un cierto, y precario, orden lógico - al menos, en los primeros capítulos- pero lo que no se puede establecer es un orden cronológico ya que no es posible encontrar referencias temporales precisas. Por otro lado, un elemento que contribuye en gran manera a esta dispersión temporal es el uso de los tiempos verbales ya que a partir de ellos se produce un reenvío constante entre el pretérito del enunciado narrativo y el presente de la enunciación. Este mecanismo nos enfrenta, una vez más, a la problemática de los dos planos, supuestamente opuestos, el de la ficción y el del proceso de ficcionalización:

Dar cuenta de lo que sigue no es, en apariencia, más que ceder a la ordinaria manía de las intrigas especulares. Pero qué se le va a hacer: la vida gusta de esas simetrías, tan toscas, que puestas en cualquier novela parecerían truculencias inverosímiles, astucias, por meridianas, ramplonas. No bien llegada la Señora, Cobra, [...] partió a la India en brazos de un boxeador [...] (461).

Por su parte, tampoco la idea de espacio puede ser reconstruida con precisión, sólo que en este caso se da por el procedimiento contrario al anterior. Si el tiempo se proponía difuso por falta de referencias, el espacio no se puede establecer por exceso de indicaciones. No se sabe cómo llegaron hasta allí ni por qué, pero en Cobra los personajes se encuentran siempre en distintos lugares aunque éstos no siempre sean claramente explicitados. Son sujetos que se desplazan constantemente desde y hacia los lugares más remotos - Tánger, India, Madrid, Cuba- y este desplazamiento 
traslada características de un sitio a otro perdiendo todo tipo de lógica geográfica:

A ras de tierra se extienden las naves, el fulgor de neón de los invernaderos.

Una represa.

Atraviesa la autopista un antílope.

Nos vamos adentrando en un bosque (519).

La interrupción de la narración mediante la interpolación de descripciones es otro recurso utilizado para producir discontinuidad en la historia. Según Gerardo Vázquez Ayora, la interrupción tiene un "efecto afásico pero encantatorio que hace al lector olvidar la anécdota perturbada su importancia por la orfebrería descriptiva" (1984:37). De esta manera, la descripción y los detalles adquieren un estatuto que exige la participación activa del lector quien se encuentra obligado constantemente a volver sobre la lectura. El enunciador pone en evidencia esta dificultad mediante el ardid de entrometerse en la instancia de la enunciación para aclarar que se trata de retomar lo ya dicho:

Iba y venía pues la Buscona, como les decía hace un párrafo, por los corredores de aquel caracol de cocinas, cámaras de vapor y camerino, atravesando en puntillas las celdas oscuras donde dormían todo el día, presas en aparatos y gasas, inmovilizadas por hilos, lascivas, emplastadas de cremas blancas, las mutantes (429).

Con dificultades o sin ellas, de lo que no hay duda, en todo caso es que toda lectura de Cobra nos remite, inexorablemente, al derroche, al desperdicio lingüístico: aquellas páginas que no pueden ser renarradas parecen ser 
páginas que se pierden, que exceden todo límite objetivable, páginas de goce... pura desmesura.

De esta manera, el segundo elemento de la tríada propuesta como corpus de análisis, la historia, se ha planteado también más como una problemática que como una respuesta. No se trata de la mera ruptura con los cánones tradicionales, sino de no reconocerlos en tanto categorías instituyentes. Se trata, pues, de esparcir sentidos, de hacer explotar Vida, Origen, Muerte, Todo. En todo caso, se trata de estallar hasta los cimientos mismos de la Literatura:

La obra de Sarduy se cierne sobre la literatura hispanoamericana como una interrogante, porque en ella se pone en jaque no ya la ideología literaria tradicional [...] sino los puntos de apoyo desde los cuales las obras modernas atacan esa tradición (González Echevarría 1987: iii).

Estallido inicial, estallido constante, estallido como forma de Ser $-\mathrm{y}$ de Hacer-, la Historia no es más que fragmentos dispersos, incoherentes, equívocos, polifónicos...

Finalmente, el problema de la Literatura, en Cobra, merece un abordaje particular. Otras estrategias, igualmente importantes a las explicadas, son puestas en marcha con la finalidad de poner en entredicho una vez más la problemática que se cierne en torno al eje ficción /no-ficción Definida por el propio Sarduy como "la incorporación de un texto extranjero al texto" (1999 [1972]: 1396) la intertextualidad es uno de los procedimientos más claramente dialógicos $\mathrm{y}$, tal vez, uno de los más representativos de la condición de obra en estallido de Cobra. Ésta adopta 
diferentes formas. Puede aparecer como citas, precisas, claramente identificables o como reminiscencias ${ }^{79}$. A veces, las obras a las que nos remite pertenecen a distintos autores pero en otras oportunidades, en cambio, son del propio Sarduy. Así, por ejemplo, algunos personajes pertenecen a sus novelas -Auxilio y Socorro vienen desde De donde son los cantantes y continúan hasta su última obra Pájaros de la playa-; se encuentran alusiones a sus propios ensayos: "Escrito sobre un cuerpo" (475); los títulos de los capítulos de la misma obra son puestos en boca de los personajes:"- A Dios dedico este mambo- musitó cuando rompieron los tambores" (484) [Las itálicas son mías].

Los intertextos que se forjan a partir de obras de otros autores $-\mathrm{y}$ de otros registros- son quizá, más numerosos y, según José Ortega tienen en Cobra dos significados posibles: "implica clara voluntad de subvertir el lenguaje" pero también "constituye [...] una celebración de la escritura por el enriquecimiento de material foráneo" (1984:41). Se transcriben aquí sólo algunos ejemplos posibles: "Me duelen la punta del pie, la rodilla, la pantorrilla y el peroné” (469); "El Conde Don Julián la condujo" (482); “como una carta robada que la policía no encuentra porque está expuesta sobre la chimenea" $(485)^{80}$. Subversión y fiesta, pero también fragmentación

\footnotetext{
79 La clasificación en citas y reminiscencias es tomada del ensayo "El barroco y el neobarroco". En éste se establece la diferencia entre ambas que consiste en la incorporación directa, en el caso de la cita, sin transformaciones; la reminiscencia, en cambio, es una incorporación "mediata en que el texto extranjero se funde al primero [...] modificando con sus texturas su geología” (1999 [1972]:1396).

${ }^{80}$ Roberto González Echevarría analiza en "El primer relato de Severo Sarduy" el cuento "El seguro" a fin de mostrar algunos ejes que se irán repitiendo a lo largo de toda la narrativa sarduyana posterior. Uno de estos elementos es, precisamente, el que corresponde al uso del lenguaje por parte de los personajes y su relación con el discurso de la publicidad: "llegan a celebrar [...] la ausencia de jerarquías, la ausencia de moral y de veracidad del lenguaje de los mass media [...] su empleo del lenguaje publicitario es una
} 
de voces literarias: palabra plurívoca rebosante de sentido, palabra no autoritaria que se mide en el diálogo con el Otro ocultado a medias/ iluminado a medias.

Una forma de dialogismo textual corresponde a la inclusión de diferentes tipos discursivos. Este último aspecto amplía significativamente el horizonte de posibilidades abriendo el procedimiento de la intertextualidad a otras clases de textos. Es posible encontrar, a lo largo de toda la novela, discursos científicos, filosóficos, religiosos, cinematográficos, publicitarios que constituyen, entonces, un elemento más de dispersión. Como los intertextos $-\mathrm{y}$ todos los procedimientos discursivos analizados- la representación en la novela de los discursos sociales vigentes produce una nueva fisura de la palabra autorizada que, en este caso es la Literatura misma, es decir, la institucionalización de la literatura, la obra en cuanto canon, en cuanto verdad reconocida, en cuanto respuesta y no interrogante. La obra que no puede hablar si no es de quiebres, de contradicciones, de historias incompletas, de sí misma.

La escritura es el arte de la elipsis (430).

La escritura es el arte de la digresión (431).

La escritura es el arte de recrear la realidad (432).

La escritura es el arte de descomponer un orden y componer un desorden (435).

Proliferación, elipsis, carnavalización, creación y descomposición, sustitución y desplazamiento, descentramiento, código que remite al código y código que envía fuera de él, metáfora y metonimia. Cómo sintetizar a 
Cobra sino por medio de la disgregación. Cómo encontrar un sentido más allá del caos y no caer en lo que se pretendió discutir desde el principio: en Cobra el lector no se encuentra, pues, con un texto que no intenta decir nada.

Uno de los conceptos funcionales para este análisis, ya propuesto al comienzo, es el de fetiche. Como sustituto del pene, que es de suma importancia durante la niñez pero que luego debe ser abandonado, el fetichismo plantea un doble proceso psicológico. Por un lado, el niño descubre la ausencia del pene en la realidad, pero, por el otro, repudia este reconocimiento mediante el mecanismo de la Verleugnung $o$ “renegación”-según Laplanche y Pontalis- que consiste en una transformación por medio de la cual puede, al mismo tiempo, conservar y abandonar su creencia en el falo femenino ${ }^{81}$."Ya lo sé, pero aún así..." (Mannoni 1997: 11) el fetichista conserva, en lugar de la creencia en el falo de la mujer, un fetiche ${ }^{82}$. Éste funciona ocultando/ develando al mismo tiempo, aquella carencia constitutiva objeto de fetichización.

81 El proceso de fetichización es similar al que Sarduy describe para explicar el funcionamiento de la metáfora barroca: "la metáfora barroca se identificaría con un modo radicalmente diferente [al de la elipsis] de la supresión, que consiste en un cambio de estructura: la represión [...] mediante la cual se encuentran empujados o mantenidos a distancia los representantes de representaciones ligados a ciertas pulsiones. En la medida en que se identifica con una organización de la carencia [...] la represión pone en acción un funcionamiento de tipo metonímico que implica la fuga indefinida de un objeto de pulsión; pero, en tanto a través del síntoma deja entrever un regreso de lo reprimido [...] se confunde exactamente con la metáfora" (1999 [1974]: 1235).

${ }^{82}$ Según Laplanche y Pontalis el fetiche puede ser un efecto clínico del complejo de castración, con lo cual esta idea remite inmediatamente a la castración de Cobra y permite pensar en una interpretación alegórica del episodio. Es así como la interpretó Roberto González Echevarría en el artículo "Memoria de apariencias y ensayo de Cobra" (1976) en el que traza una "evolución" en las novelas sarduyanas desde Gestos hasta Cobra en función de una figura que entiende como "alegoría del corte". Esta se produce, en la primera novela, mediante la parodia de El acoso de Carpentier, en De donde son los cantantes por la ruptura de los orígenes y en Cobra porque es el momento en que se funden 
Este mismo procedimiento, la fetichización, es llevado a cabo en Cobra a través del lenguaje que ha sido desplazado hacia el centro de la escena y desde ese lugar se le ha otorgado la función -lujo y abigarramiento de por medio- de ocultar develando las carencias constitutivas de la obra: el Sujeto, la historia/ Historia y la Literatura en tanto construcciones homogéneas:

Por una parte el lenguaje lo asalta todo para hacerse ostensible, por otra es utilizado para hacer ostensible lo que el lenguaje todavía no ha petrificado [...] percepciones $y$ representaciones que no han estado atadas aún a las nociones y definiciones, a las categorías y mitos, cómodamente instalados en el orden socio-cultural (Vázquez Ayora 1984: 39).

Descomponer un orden para recrear la realidad componiendo un nuevo desorden a través de la elipsis y la digresión, el lenguaje barroco, lenguaje del descentramiento y la revolución se ilumina a sí mismo para poner en evidencia la falsa totalidad de las representaciones modernas. Ni Historia, ni Literatura, ni Sujeto, es el lenguaje de la experimentación telqueliana y neobarroca que pone sus fundamentos en la subjetividad escindida y carente de Lacan, en el derroche y el goce de Barthes, en la diseminación derridiana. Construye una política del lenguaje que instaura la diferencia $-\mathrm{y}$ la différance - , perturba los órdenes, disloca e inquieta, que no pretende suturar la falla; un lenguaje que se instaura en el corte, la dispersión... el exilio...un lenguaje político.

muerte y deseo "para abolirse mutuamente —el falo, significante del deseo erótico y de la ilusoria plenitud se convierte aquí así en símbolo de una eucaristía invertida, vaciada- en vez de regreso, de reunión con el padre, con la plenitud perdida, el falo representa el significante desasido, representacional, flotante, tras la cancelación final- dedo que apunta al vacío escénico y al silencio sideral” (1999 [1976]: 1760). Así, la alegoría, según González Echevarría, la alegoría es, dentro del contexto occidental, el único recurso que le permite a Sarduy desplegar una escritura teatral que expulse toda sujeción autoritaria, subjetiva, profunda (1761). 


\title{
II. 4. Para que nadie sepa que tengo miedo. Cocuyo: búsqueda
}

\section{y recuperación de un mundo inexistente}

\begin{abstract}
Supo de una manera opaca, como si recibiera un aviso informulado pero nefasto, que iba a estar siempre perdido, desorientado, sin brújula interior que lo guiara, como si toda la Tierra fuera para él un laborioso laberinto, o un perverso espejismo de muros móviles que alguien urdía para perderlo, para hacerlo caer.
\end{abstract}

Severo Sarduy, Cocuyo (1990)

Como hemos visto, entender lo barroco desde la perspectiva de Severo Sarduy es admitir que uno de los elementos centrales —quizá el más central de todos- sea el concepto de crisis. En torno a él, se construyen claves de comprensión tanto para problemáticas socioculturales como individuales y artísticas. Así, podemos afirmar que, si el sujeto barroco es uno que está descentrado, desdoblado, que ha perdido su identidad única, y la Historia y la Literatura construcciones discursivas que se arman de jirones y fracturas, de inclusiones y exclusiones, de ocultamientos y develamientos, la escritura es uno de los medios - privilegiado, ciertamente, pero no el único- a través del cual estas construcciones se hacen posibles. Proliferación y elipsis, carencia y abundancia: las claves de esta escritura barroca y, por lo mismo, las dos caras de una misma moneda.

En este complejo entramado se enmarca la narrativa sarduyana, en este caso, la novela Cocuyo (1990), obra en la que el autor cubano intenta recuperar el sentido, el origen, mediante la reescritura de lo que, según Roberto González Echevarría fueron las "catástrofes" de su vida: "En 
Sarduy la literatura es un acto de recuperación" [en el que] "lo que se recupera es el sentido, en la acepción más amplia de la palabra, inclusive la más familiar: recobrar el sentido, volver en sî" (1987:3). Este acto de recuperación es constante y se lleva a cabo en cada etapa de la obra de Sarduy porque cada una de ellas, a su vez, está marcada por una catástrofe que origina la pérdida y que está directamente relacionada con la vida del cubano. Suceden en tres niveles diferentes: el biográfico, el histórico y el literario. A nivel de su biografía, las salidas de Camagüey, primero, y de Cuba después, marcan el comienzo de una ruptura que, en este caso, tendrá que ver con el viaje y el alejamiento de la isla. A nivel histórico y literario, las catástrofes son la Revolución cubana, por un lado, y el distanciamiento del grupo de la revista Orígenes, por el otro.

Y es, precisamente, este acto de pérdida y recuperación el que inscribe la obra sarduyana en el doble procedimiento barroco de la proliferación y la elipsis, ya que la escritura tiene una función (des)ordenadora del caos (aparente) que le permite al autor buscar el sentido pero no en la totalidad causante de su ruptura inicial sino en su negación, en su fisura: "La ausencia, la separación, la carencia marcan su obra, tanto como el deseo de una plenitud recuperada" (González Echevarría: 5).

Las peripecias de Cocuyo comienzan siendo él un niño -precoz, desproporcionado, más parecido a un cocuyo que a un niño- todavía muy pequeño, cuando "Sin levantarse del orinal, y agarrado de las asas, se deja rodar tinajón abajo" (799) ante la mirada inquisidora de sus tías. Pero la verdadera catástrofe será posterior: cuando la llegada del ciclón a la isla 
pone a sus habitantes en situación de alarma y los obliga a ser los espectadores pasivos de un desastre repetido. Aunque apenas puede balbucear algunas palabras, la familia le exige oficiar de relator de los destrozos que produce la violencia incontenida de la naturaleza. Pero la situación lo desborda y lo que ve es mucho más de lo que puede entender. Una plancha de zinc que, dando "media vuelta en el aire [...] como una daga de plata [...] arrancó la cabeza de un negro" (809) lo enfrenta a una realidad que de ninguna manera consigue poner en palabras. El miedo -el mismo que experimentó anteriormente frente a las miradas de sus tías- se renueva focalizado en la crueldad de la naturaleza y, junto a la burla de sus familiares, da inicio a la primera de las catástrofes que marcarán la vida del personaje sumiéndolo en un estado crítico del que intentará salir con una decisión terminante. Así, ante la incapacidad de pronunciar las palabras que lo sacarían de su estado de angustia, Cocuyo decide terminar con esa lamentable situación esparciendo matarratas en cada una de las tazas de té que les servirá a todos los miembros de su familia. De esta manera, atentando contra su estirpe, desafiando la autoridad de los mayores —significativamente incluido su padre- inicia un viaje que lo llevará inexorablemente al exilio y que estará signado por el descubrimiento continuo de nuevas realidades que lo alejarán paulatinamente de su inocencia primigenia: "No sabía adónde ir ni qué hacer. Sabía, eso sí, que ya nunca más tendría casa ni familia, ni lugar de reposo, ni de origen. La fuga lo había desraizado, lanzado a un exilio sin regreso" (829).

En relación con la problemática del padre, René Prieto aborda Colibrí desde una perspectiva claramente psicoanalítica que permite 
establecer estrechas relaciones entre esta novela y Сосиуо. Para esto, parte de la premisa barthesiana según la cual "toda obra de ficción es una metáfora del cuerpo y, más exactamente, del cuerpo erótico" (1991:317) con el objeto de analizar la función que cumple la voz del padre en lo que él considera una trilogía formada por Cobra, Maitreya y Colibrí. Según Prieto, Sarduy dramatiza en estas novelas las pulsiones de su propia psique -el anhelo del cuerpo materno y el rechazo del padre- por lo que la voz del padre debe verse como una alusión a la norma impuesta por la autoridad durante el desarrollo psíquico (319) que no sólo desautoriza la inclinación sexual del hijo sino la sublimación de esta sexualidad que es la escritura (320). La resolución sarduyana en ambas obras no es el desconocimiento o la negación sino la inversión del mandato mediante la transgresión de la norma -lingüística discursiva, genérica-. Así, si en Colibrí esta transgresión se efectúa en la discusión que entabla el narrador con su padre, en Cocuyo queda establecida en este acto disruptivo que implican tanto el asesinato como el abandono del hogar.

Ya fuera de su casa y alejado de su familia, la catástrofe inicial irá actualizándose a partir de otras que no serán más que distintas "versiones" de la primera. Así, por ejemplo, Cocuyo descubre que lo que él consideraba un hogar para huérfanas no es más que una casa desvencijada y sucia en la que se negocia a las niñas para el comercio de la prostitución; que la Bondadosa no es tan bondadosa como creía; que toda la historia de la isla está hecha de hombres y mujeres vendidos como esclavos en los muelles del puerto y sumidos en la miseria de otros hombres y de otras mujeres. Descubre de este modo, la naturaleza humana y esto le vale para confirmar 
lo que ya había empezado a aprender tiempo atrás, en el seno de su propia familia: "El género humano le apareció entonces, [...] como una deyección irrecuperable, como un resto. Eso: el residuo, la ruina de un ser ideal tramado en los orígenes por algún dios iluso y a fin de cuentas reducido a este desparpajo de gestos, a esta suciedad esencial" (901).

De tal manera, toda la vida de Cocuyo se convierte en una serie interminable de aprendizajes y en cada uno de ellos se renueva, junto a las catástrofes acaecidas a nivel de la historia en la isla y con respecto a su familia, su catástrofe personal. Cada verdad que descubre en los demás —a nivel social— le permite develar alguna faceta de su propia biografía. Así, el ritual de iniciación al que es sometida Ada antes de ser vendida para la prostitución lo empuja a su propio ritual llevado a cabo por dos viejas prostitutas que lo inician en una sexualidad doble en la que tres elementos muy significativos en la obra se conjugan: el miedo, los recuerdos y la escritura. El lápiz y el cuaderno que robó cuando descubrió que ya sabía leer permanecen en el bolsillo del pantalón rozándole el sexo, como lo hace la mano de la prostituta, mientras él siente el llanto cercano y recuerda "lo que había sentido cuando el orinal rodaba, y él prendido a sus asas, tinajón abajo, $[\ldots]$ en medio de las risotadas de las tías, hasta que el bacín de loza se estrelló contra el suelo" (879). Esta escena de iniciación sexual remite a Cocuyo a la escena inicial de su viaje y establece correspondencias entre la sexualidad doble que le proponen las prostitutas, la homosexualidad como correlato del exceso que implican las heces del pequeño y la incapacidad narrativa que experimenta el protagonista frente al terror del huracán: "Las tías emprendieron una danza reprobatoria — porque un machito no puede 
ablandarse - [...] y parodiaban las vacilaciones y el silencio del narrador" (810). Así, Sarduy recupera una problemática cara a la cultura de la Revolución que es la de las excrecencias ligadas a la homosexualidad en la figura de la "gusanera".

En un solo proceso, entonces, quedan instaurados en Cocuyo un paradigma de virilidad y un paradigma de narrador a los cuales el personaje no responde. Ante la brutalidad de la naturaleza, ante la sexualidad excesiva, ante un sujeto desequilibrado, el lenguaje se convierte en un absurdo irremediable o, directamente, en una inexorable imposibilidad si lo que se pretende a través de él es comunicar la catástrofe o, lo que es lo mismo, recuperar un sentido. De esta manera, sujeto miedoso, dubitativo, sexualmente ambiguo, desproporcionado... Sujeto cuyo cuerpo es a la vez una carencia y una abundancia, Cocuyo debe exiliarse de su mundo originario porque es una pieza que no encaja en tan pretendida unidad familiar. Pero este exilio es doble — geográfico y psíquico- y lo arroja desesperadamente a una búsqueda que nunca puede ser del todo satisfactoria; búsqueda de su lugar pero también de sí mismo.

En ambas búsquedas, lo que Cocuyo encuentra dista mucho de ser una respuesta o un lugar. Paradójicamente, la recuperación que en este nivel se produce provoca, en el personaje, más exilio, más alejamiento. Así sucede cuando pretende recuperar un espacio idílico frente a la crueldad de los acontecimientos y debe recurrir, para ello, a la negación de la realidad: "Para poder sobrevivir [...] tengo que convencerme que todo lo que estoy viendo y oyendo no es real" (895). En el mismo sentido, cuando, por temor 
a las burlas, se propone cambiar, ser otro para ocultar el miedo que siente, aún a sabiendas que esto le causará sólo escisión: "Es la necesidad "urgente, urgente" —se repite a sí mismo esta palabra— de ser otro lo que explica esa capacidad de desdoblamiento" (826).

La respuesta a ese exilio parece estar en una recuperación que nunca es completa y que se da por medio del recuerdo que le permite a Cocuyo establecer ciertos paralelismos entre el mundo perdido -el de su infancia, su familia y su casa- y su vida presente. Así, por ejemplo, Cocuyo no puede dejar de pensar en su hermana cuando se encuentra con Ada en el prostíbulo, como tampoco puede dejar de ver a su madre en la Bondadosa. Pero la recuperación más patética -y a la vez, quizá, la más falaz- parece ser la de su casa y en ella, la de su historia, en el último capítulo de la novela. Allí se reúne una serie de elementos que nuevamente reenvían al personaje a la escena inicial de su vida. En una casona vieja, cercana al mar, que mucho nos recuerda la descripción de la casa de su niñez - y mucho también al prostíbulo de Colibrí-, reaparece Ada, ya prostituida, obligada a danzar frente a la mirada escrutadora -como las de sus propias tías- de los hombres que asisten a una escena de morboso placer. Entiende que su propia hermana puede estar en una situación similar y se rebela nuevamente contra esa naturaleza humana que ya había empezado a descubrir tiempo atrás, completando de esta manera un aprendizaje que no hace más que devolverlo al origen de todo: "Se juró volver, para exterminarlos a todos. Y a él mismo con ellos, y así limpiar el universo de tanto estiércol. Sabía muy bien dónde comprar matarratas, y cómo mezclarlo, sin que nadie se diera cuenta, con el ron" (914). 
La catástrofe, entonces, es la causa del exilio que empuja a Cocuyo a una búsqueda constante de sus orígenes, a un intento de recuperar el mundo perdido, pero también es, paradójicamente, parte constitutiva de él en tanto, fragmentado y contradictorio ese mundo sólo puede ser recuperado a través de la carencia, el conflicto, la pérdida, el exceso, el desdoblamiento...Y la escritura, porque si a nivel de la trama narrativa estas pérdidas corresponden a la vida del personaje principal, en el nivel de la enunciación implican referencias a elementos extratextuales que atañen al posicionamiento de Sarduy frente a sus propias catástrofes.

"Para que nadie sepa que tengo miedo" [Las itálicas son mías] (799) es el nombre del primer capítulo y primera frase de toda la obra, y con esto, el problema ya está planteado... Está claro que en esta primera frase la voz que enuncia corresponde a un narrador en primera persona que asume el protagonismo del relato, pero basta con que avancemos hasta la segunda para que la enunciación se haya trasladado a un narrador en tercera persona que mira al personaje desde la distancia, no sólo de un observador testigo, sino desde el desconocimiento mismo, y desde allí confiesa habérselo encontrado "así, de golpe y porrazo" (799). La ambivalencia discursiva se intensifica y adquiere relevancia a medida que avanza el relato y estas estrategias enunciativas aparecen con mayor frecuencia. Pero también, porque se le suman a otras estrategias. Encontramos comentarios y opiniones de los personajes, inclusiones del y referencias al enunciatario, notas a pie de página y referencias en forma de notas a los críticos de la propia obra: "Dice Gustavo Guerrero que "el martín pescador muere ciego". Tanto se tiran al agua que se queman los párpados. A él se lo dijo un 
pescador de la Laguna de la Restinga, en la isla Margarita, Venezuela" (802).

Es posible afirmar, entonces, que estas estrategias discursivas trazan, en lo formal, la ruptura de la unidad de enunciación; pero podemos decir también que, a nivel discursivo, actualizan el tópico de las catástrofes y la recuperación sólo que ahora, entendidos no ya desde Cocuyo sino desde el mismo autor. Así, ante la catástrofe histórica que fue la Revolución cubana, Sarduy propone su propio modo de recobrar el sentido, desde una escritura, como así también, desde una postura personal que implica su sexualidad. En torno a la primera, desde una mirada crítica que le permite hacer el paso inverso a sus primeros años de trayectoria, recuperar a quien fue uno de sus más reconocidos maestros, José Lezama Lima: "La Universidad de La Habana en Paradiso. Aquí aparece dos décadas y una dictadura después: los pitagóricos debates lezamescos se despliegan bajo Machado; este amanerado melodrama, bajo Batista (Nota del editor)" (816) y crear una genealogía en la que él mismo se incluye en la "Era Lezama" y se excluye de otros grupos de escritores como, por ejemplo, los del Boom.

El recorrido sarduyano empieza a completar un regreso. Desde el viaje iniciado en Gestos se ha ido radicalizando en la complejidad de sus estructuras textuales hasta llegar a Cobra como referente extremo de ruptura, fragmentación y excesos. Cocuyo, en cambio, parece estar marcado, desde su trama narrativa, por una vuelta a lo que, veremos, González Echevarría denominó “formas convencionales” resolviendo así la complejidad genérica en una organización en parábola. Sin embargo, queda 
claro que la sencillez, la convencionalidad, las formas siempre velan, en Sarduy, algo más: aquello que no puede ser nunca plenamente dicho, nunca plenamente recuperado.

Fuera de su tierra natal - Camagüey, Cuba- y desafiante de los modelos de hombre y de intelectual impuestos por la Revolución, el escritor cubano no sólo es un exilado geográfico, físico, sino también, es un exilado de sí mismo porque en su búsqueda lo que pretende recuperar no es precisamente el lugar sino la frontera, no la verdad sino la pregunta. Lo que pretende recuperar no es la Literatura sino la escritura en acto, en devenir; el hacer escriturario por medio del cual reinscribe sus catástrofes originarias en Cocuyo para reconstruir su historia y reconstruirse a sí mismo pero no en la totalidad - falsa - de la que ya fue excluido sino en la fisura, en el corte en el que se recobra el sentido inicial de las cosas. 


\section{Escrituras del cuerpo}

\section{1. Cuerpo, sexo y género: devenires de una subjetividad}

Sentía, en medio de la muchedumbre, la escoria de su cuerpo, la sensación de arrastrar una suciedad o un peso del que no podía librarse: lo rodeaba la culpa como un aura opaca; una lepra invisible le devoraba la piel. [...] Quería dormir mucho. Morir y volver a nacer, volver al estado que precede al nacimiento y sucede a la muerte. Quería desexistir. Ser otro.

Severo Sarduy, Cocuyo (1990)

El cuerpo es, y ha sido a lo largo del tiempo, materia de constante reflexión, ya sea abordado desde el punto de vista personal — público o privado—o colectivo; ya desde lo científico como desde lo artístico, desde el ámbito religioso tanto como en el espacio secular. Esto ha dado lugar a la aparición de numerosas interpretaciones, productos de las diversas intencionalidades sociales, educativas y políticas con las que se han llevado adelante los estudios en cuestión y que confirman lo que la crítica moderna proclama a todas voces: la necesidad de entenderlo $\longrightarrow$ o mejor dicho, estudiarlo— no tanto en razón de su cualidad biologicista sino en función de su categoría de construcción cultural, lo que, en términos de Roy Porter sería “considerar el cuerpo como ha sido experimentado y expresado dentro de los sistemas culturales concretos" (1993: 258). Esto es, tener en cuenta la narración de sus modos de construcción en contraposición a la historia de sus 
representaciones en tanto esta se refiere al cuerpo real considerado como una entidad sin historia mientras que la historia de sus modos de producción estima el cuerpo inserto y penetrado por un momento y una cultura determinados (Feher 1990:11), como una construcción simbólica tributaria de "un estado social, de una visión del mundo y, dentro de esta última, de una definición de la persona" (Le Breton 2002: 13).

A diferencia de las representaciones corporales de las sociedades tradicionales, el cuerpo de la modernidad, vinculado a una concepción individualista de la estructura social y al pensamiento racional positivo y laico sobre la naturaleza, implica la ruptura del sujeto con los otros, con el cosmos y consigo mismo aunque, paradójicamente, también marca el lugar de la diferencia del sujeto, de su distinción (8). De tal manera, el cuerpo en las sociedades occidentales se transformó en una posesión que responde a esta paradoja y da lugar a un discurso dualista que, al mismo tiempo que lo instaura como signo de distinción entre los sujetos y habla de su "liberación" lo disocia del propio sujeto mediante prácticas rituales cotidianas que tienen la finalidad de contribuir a su borramiento (9). Desde el siglo XVI, comienza a aparecer en las capas más formadas de la sociedad este cuerpo racional, "liso, moral, sin asperezas, limitado, reticente a toda transformación eventual” que, separado de los demás y encerrado en sí mismo se irá oponiendo paulatinamente a las funciones carnavalescas, la risa y las tradiciones de la plaza pública de las culturas del medioevo y el Renacimiento (32) para dar lugar al cuerpo de la Modernidad cuyo privilegio está puesto en otros órganos y funciones, por ejemplo, el rostro y la mirada. Contemplativo y contemplado a un mismo tiempo, el cuerpo, 
plegado al discurso dualista que caracteriza a esta etapa histórica en todos los ámbitos, se construye en base a una metáfora mecanicista que propicia la separación cartesiana cuerpo/ alma y, consecuentemente, da lugar al florecimiento de la biomedicina en tanto terapia despojada de todo indicio sentimental o subjetivo que tiene como única finalidad el tratamiento del cuerpo como un ensamblado de partes relativamente independientes entre sí que constituyen una máquina ${ }^{83}$. Visto de esta manera, es sometido a una racionalización minuciosa que tiene como objetivo la aplicación de la técnica en pos de una eficaz corrección de las insuficiencias corporales. Sin embargo, aun cuando la anatomía médica estableció las condiciones necesarias para el análisis minucioso del cuerpo a través de las disecciones que se comenzaron a realizar sobre los cadáveres, la asimilación del cuerpo a la mecánica tiene sus límites precisos en el hombre y la muerte, ambos restos inaprehensibles para los cuales la técnica no ha encontrado respuestas definitivas, ni siquiera, en los cada vez más sofisticados métodos para prolongar la vida artificialmente, ya que estos no hacen más que ahondar la brecha entre el hombre y su cuerpo y, de tal manera, poner en vigencia un profundo debate ético ${ }^{84}$. En tal caso, es la escritura, y más específicamente la literatura - lo veremos en el análisis de la obra sarduyana- la "técnica"

\footnotetext{
${ }^{83}$ Según Roy Porter, la separación entre cuerpo y alma fue una construcción que propusieron, cada uno por su lado, tanto los componentes clásicos como los judeocristianos de nuestra herencia cultural. Esta visión dualista del hombre dio lugar, en ambos casos, al ensalzamiento de la mente en detrimento del cuerpo (1993:256).

${ }^{84}$ En este sentido, vale traer a colación el capítulo que Rossi Braidotti titula "Órganos sin cuerpos" (2002) ya que en este trabajo la autora aborda la revolución científica producida en torno del cuerpo durante los '90 como una "revolución ideológica" en tanto entiende que durante este período se dieron tres rupturas fundamentales: la pérdida de la noción de unidad del cuerpo vivo, la desaparición de la referencia a la muerte y el disloque del tiempo. En tal caso, una de las principales causas de estos cambios es el empleo de técnicas científico-médicas como el transplante de órganos o la reproducción sin relaciones sexuales que permiten la manipulación de los ciclos vitales a extremos nunca antes sospechados.
} 
privilegiada a fines del siglo XX para dar cuenta de la inaprehensibilidad de la muerte y de la enfermedad del sida que se instituyó en estos tiempos como los inicios de la crónica de una muerte anunciada.

En obvia relación con las teorizaciones sobre la subjetividad, la década del sesenta del pasado siglo XX fue la época que marcó un hito en la construcción teórica del cuerpo ya que volvió a poner al sexo y la sexualidad en el centro de los debates constituyendo asi un punto de inflexión ineludible en el abordaje de temáticas que lograron una relevancia singular en las décadas posteriores tales como las teorías en torno al lesbianismo y la homosexualidad masculina y, un poco más tarde aún, las preocupaciones que suscitó la expansión del sida y su pronta vinculación discriminatoria y estigmatizante con las prácticas sexuales homoeróticas ${ }^{85}$.

Según David Le Breton, fue la crisis de las modalidades físicas de vinculación del hombre con los otros y con el mundo lo que tomó relevancia singular a finales de los años sesenta con el feminismo, la revolución sexual, la expresión corporal y la aparición de nuevas terapias, entre otros, lo que dio lugar a un nuevo imaginario sobre el cuerpo del cual ningún sector de la sociedad quedó exento (2002: 9-10). Si el cuerpo, en cuanto encarna al hombre, constituye su frontera, el elemento primordial y básico de

\footnotetext{
${ }^{85}$ A propósito de esto, conviene recordar que, si bien una de las teorías que prevaleció entre algunos integrantes del grupo Tel Quel fue la de la "desaparición del sujeto" en el mismo grupo se fue gestando la noción de "sujeto en proceso", que dio lugar también al concepto de "sujeto disidente", ambos elaborados en primera medida por Julia Kristeva y con la particularidad de traer a colación algunos elementos que no habían sido desarrollados por el grupo, esto es el cuerpo, su materialidad y, consecuentemente, su condición política. En tal caso, si el sujeto desaparece —entiéndase que se trata del sujeto racional- no es porque se esté pensando en su muerte sino porque se transforma en su cuerpo y a partir de él adquiere consistencia (ver cap. I). Evidentemente no es esto lo único que se ha dicho respecto del cuerpo en el grupo telqueliano pero sí lo que me interesa particularmente aquí en tanto entiendo que constituye uno de los puentes fundamentales entre sus teorías y las venideras. Un ejemplo de esto son, nuevamente, los trabajos de Kristeva leídos, retomados y discutidos tanto en los estudios de género, como en las teorías queer o los abordajes feministas.
} 
individuación, el lugar del corte y la diferencia individual, también tiene el privilegio de la reconciliación con los demás por lo que éste es el momento en el que se busca convertirlo en factor de inclusión y no de exclusión, sacarlo de su función de obstáculo en la relación con los otros para transformarlo en una posible fuente de conexiones entre los individuos.

Aún más, es indispensable tener en cuenta que este nuevo imaginario sobre el cuerpo se construyó en base a toda una problemática histórica, política, económica y cultural que marcó la singularidad de la época adoptando la crítica, la rebelión, la revuelta, el inconformismo y, hasta en algunos casos, la violencia, como herramientas fundamentales en pos de un objetivo que tuvo la particularidad de gozar, por primera vez, de cierta "universalidad" asumida en la figura generacional de la "juventud". Según Hobsbawn, ésta no sólo se convirtió en la matriz de una revolución cultural sino que adoptó un sentido mucho más amplio transformándose en generadora de un cambio que implicó el comportamiento, las costumbres, el modo de disponer del tiempo de ocio, las artes, etc. Tuvo dos características importantes: fue populista e iconoclasta en el sentido en que cada quien debía tomar sus decisiones libremente, aunque en la práctica hubo cierta imposición de modas que, precisamente, tuvo que ver con adoptar formas, costumbres, lenguajes, indumentarias, de las clases más populares. Esta última característica entronca, en opinión de Hobsbawn, con el fervor revolucionario que demostraron tener los estudiantes en episodios puntuales como los del Mayo francés y con el espíritu de liberación que los condujo durante todas estas manifestaciones en las que adoptaron el sexo y el consumo de drogas como las formas más notorias y evidentes de romper 
con las leyes y normas del Estado y de los padres (1998: 331-4). Pero no sólo estas sino todas las relaciones de poder fueron puestas en discusión y, entre las más notorias, la relación político burgués-político revolucionario —causa de las más estridentes rupturas, exclusiones y exilios políticos del gobierno de Castro en Cuba, de la revisión de los conceptos de "compromiso" y "literatura comprometida" y de la pérdida de Sartre de su condición de "faro intelectual", de las críticas y censuras sufridas por el grupo Tel Quel-, la relación hombre-mujer —que dio lugar a un nuevo feminismo en boga hasta hoy - y la relación entre represión y libertad sexual.

Si la focalización en el sexo es un modo de abordar el cuerpo que se repite como constante a lo largo de toda su historia es necesario advertir que éste fue adquiriendo significaciones diferentes en función de las diferentes circunstancias socio-históricas y de las relaciones de poder que en torno de ellas se han instaurado en tanto constituye un factor fundamental en la conservación o subversión de las estructuras establecidas. Tanto es así que, mientras que en la Antigüedad los órganos reproductores femeninos eran entendidos como el reverso interno de los órganos masculinos $\mathrm{y}$, en consecuencia, las mujeres eran vistas como hombres incompletos que por falta de cierto calor vital habían retenido en su interior las estructuras sexuales masculinas, a finales del siglo XVIII cambió la naturaleza sexual por lo que se puso el énfasis en considerar y demostrar diferencias fundamentales entre hombres y mujeres a través de distinciones biológicas observables (Laqueur 1994: 22-3). Es de notar entonces, que el modelo en el que hombres y mujeres se ordenaban según el grado de perfección 
metafísica en función de que a la existencia de dos géneros correspondía la de un solo sexo perduró en el tiempo no por falta de conocimientos capaces de refutarlo sino por su fuerte vinculación con el poder en tanto, en un mundo predominantemente masculino, este modelo de sexo único permitía poner más en evidencia que el hombre era la medida de todas las cosas y la mujer no existía como categoría ontológica distinta de él (120). Esta construcción de un sexo para dos géneros, provocó una tensión, en opinión de Laqueur, que puede verse tanto en la anatomía como en las representaciones literarias, en los tratados científicos o en los ensayos de Montaigne. Dice Laqueur: "La política cultural de al menos dos géneros no está nunca en equilibrio con la "biología", o con la política cultural alternativa del sexo único" (202) aunque había algunas cosas aceptadas anticipadamente. Esto es, que había dos sexos sociales o géneros que se interpretaban como naturales y a los que correspondían derechos y obligaciones radicalmente diferentes pero que, a su vez se sustentaban sobre el sexo biológico en tanto determinante de los niveles en la escala corporal que permitían definir si tal sujeto era hombre o mujer por lo que, en resumidas cuentas, el cuerpo era un fundamento absoluto, aunque inestable, del sistema de género bipolar (235-6).

Por su parte, el siglo XVIII dio paso a un modelo de dimorfismo radical en tanto, aunque el modelo de sexo único no desapareció definitivamente, dos sexos, nuevos y distintos, se irían reconociendo cada vez con más insistencia en el cuerpo, pues según Laqueur: "Una anatomía y una fisiología de lo inconmensurable sustituyó a una metafísica de la jerarquía en la representación de la mujer en relación con el hombre” (24). 
Así, la mujer dejó de ser la versión menor del hombre en un eje vertical de múltiples gradaciones para constituirse como un sujeto por completo diferente. En tal caso, los órganos de la reproducción fueron el pilar de esta diferencia inconmensurable por lo que se instituyeron en el paradigma de una jerarquía que puso su lugar de batalla en el cuerpo de las mujeres impregnado de nuevos significados sociales sobre los que inventaron los dos sexos como fundamentos de los dos géneros. Según Laqueur esta invención se dio a partir de dos formas principales: una epistemológica, que implicó el surgimiento de cierto escepticismo frente a hechos considerados imposibles —el cambio de sexo, por ejemplo- y un mayor aferramiento a los observables y, consecuentemente, la importancia otorgada al fundamento "llano, horizontal e inmutable" del hecho físico (262) y otra política. Las luchas por el poder, que se dieron en el contexto de un siglo XVIII en el que la esfera pública se vio ampliada y en el período posrevolucionario del XIX, se trasladó desde los roles de género hacia la naturaleza y el sexo biológico.

En todo caso, lo importante es que no fue la epistemología por sí misma la que produjo los dos sexos opuestos sino a expensas de ciertas circunstancias históricas con la capacidad de generar nuevas formas de constituir el sujeto y las realidades sociales en que los humanos viven, por lo que los dos sexos, tanto como el sexo único, fueron y son construcciones culturales operando como dispositivos políticos de poder ${ }^{86}$.

\footnotetext{
${ }^{86}$ Otros aspectos que contribuyeron a este cambio en la reinterpretación del cuerpo y la sexualidad fueron, en opinión de Laqueur, "el crecimiento de la religión evangélica, la teoría política de la Ilustración, el desarrollo de nuevos tipos de espacios públicos en el siglo XVIII, las ideas de Locke sobre el matrimonio como contrato, las drásticas posibilidades de cambio social abiertas por la Revolución francesa, el feminismo subsiguiente a la Revolución, el sistema fabril con su reestructuración de la división sexual del trabajo, el crecimiento de una economía de libre mercado de servicios y mercancías, el nacimiento de las clases" (33).
} 
Sin embargo, recién desde la aparición de la segunda ola de feminismo, a partir de los años sesenta, la construcción epistemológica permitió entrever, teorizar y dado el carácter particular de la época, politizar de manera explícita las nociones de sexo, género y sexualidad en tanto dispositivos culturales. Uno de los trabajos que más repercusiones ha tenido, en este sentido, es la Historia de la sexualidad que Michel Foucault escribió en tres tomos entre los años 1976 y 1984. En el primero de estos libros, "La voluntad de saber", Foucault se propone indagar lo que sucede en la sociedad occidental a partir del siglo XVIII en tanto, al mismo tiempo que se proclama como una sociedad represora de la sexualidad, se produce una proliferación incesante de múltiples y variados discursos, cuyo tema ronda en torno a la problemática del sexo, con un objetivo fundamental que es el de "expulsar de la realidad las formas de sexualidad no sometidas a la economía estricta de la reproducción" (2000: 48), definiendo normas, clasificando desvíos, organizando controles pedagógicos y curas médicas para, de esta manera "montar una sexualidad económicamente útil y políticamente conservadora" (49).

Aparecen, entonces, dos esferas constrapuestas, que se impugnan entre sí pero que a la vez se necesitan para diferenciarse y definirse lo que implica todo este esfuerzo discursivo de nombrar, clasificar y legislar. Se refuerza, por un lado, el movimiento centrífugo hacia la monogamia heterosexual que, si bien se mantiene como la regla interna del campo de las prácticas y los placeres, cada vez se habla menos y más sobriamente de ella. Por otro lado, surge la dimensión del "contra natura" que comienza a ganar en autonomía en la misma proporción en que cada una de las prácticas es 
identificada, clasificada y normativizada. Quedan, en esta esfera, los locos, los perversos y los delincuentes para quienes se monta todo un sistema de control y poder en el que la medicina ocupa un lugar central aduciendo patologías, inventando terapias e imponiendo conductas de cuidado e higiene. Es una mecánica de poder que persigue la disparidad pero no para suprimirla sino para darle una "realidad analítica, visible y permanente: la hunde en los cuerpos, la desliza bajo las conductas, la convierte en principio de clasificación y de inteligibilidad, la constituye en razón de ser y orden natural del desorden" (57). Es el momento, entonces, que da cabida a la figura de la homosexualidad en tanto categoría psicológica, pisquiátrica y médica y caracterizada no tanto por el tipo de relaciones sexuales sino como una determinada sensibilidad sexual, una manera de invertir en sí mismo lo masculino y lo femenino, dicho de otro modo, una esencia, una distorsión de la normalidad que deberá ser sometida a los controles discursivos y terapéuticos tanto como cualquiera de las demás sexualidades consideradas erráticas. Pero en tanto, según Foucault, no existe por un lado el discurso del poder y enfrente uno que se le oponga sino que ambos son bloques en un campo de relaciones de fuerza que facilitan la coexistencia de discursos diferentes y contradictorios dentro de una misma estrategia, es necesario advertir que frente al discurso de control se constituyó uno de rechazo mediante el cual la homosexualidad comenzó a hablar de sí misma reivindicando su legitimidad en la medida en que incorporaba al vocabulario las categorías con las que era frecuentemente descalificada (124).

Sin embargo, es importante entender que el sexo no fue únicamente una cuestión de ley, interdicción o placer sino también de verdad y falsedad, 
de saber, por lo que una de las formas discursivas privilegiadas fue la confesión en tanto dispositivo que obliga a la expresión exhaustiva de un secreto individual desplegando una relación de poder en la que el sujeto que habla es el mismo sujeto del enunciado y el interlocutor, cuya presencia es obligada, juzga, castiga, perdona, consuela, etc (78). Siguiendo a Foucault, la verdad, en este caso, no estaría dada por la educación ni por la tradición sino por el vínculo entre el sujeto de la enunciación y del enunciado y por la instancia de dominación que está radicada, contrariamente a lo esperable, no en quien sabe sino en quien interroga (79).

En relación con el género como categoría analítica, también es a partir de la década del sesenta que las feministas de la diferencia lo ponen en juego para explicar las desigualdades entre hombres y mujeres y la conformación de lo femenino y lo masculino como una relación histórica y cultural entre ambos términos por lo que el énfasis fue puesto en romper con la naturalización que impone a este vínculo una correspondencia directa con el sexo en cuanto dato biológico y -falazmente, ya lo vimoscomprobable. El género constituye el conjunto de prácticas, símbolos, normas, representaciones y valores sociales, elaborados e impuestos sobre la diferencia sexual anatómica y fisiológica, que imprime una marca indeleble sobre el sujeto. Esta marca, que prácticamente funciona como un estigma, obliga al sujeto a ocupar un determinado lugar en la sociedad, es decir, asumir un rol impuesto por la naturalización de ciertas contingencias históricas y sociales vinculadas con el cuerpo y el sexo que, aunque representaciones construidas, son internalizadas y socializadas en esta 
naturalización que oculta una ideología de dominación y exclusión de lo femenino a favor de lo masculino ${ }^{87}$.

Judith Butler es una de las teóricas feministas más relevantes en los últimos tiempos y, como la gran mayoría de sus colegas, deudora, aunque en este caso, crítica, de las ideas precursoras que Simone de Beauvoir manifestara en su ya canónico El segundo sexo, en $1949^{88}$.

Butler retoma el concepto de género que se había venido discutiendo desde mitad de siglo en adelante e introduce en él una variante, en mi opinión de suma importancia, que es la del discurso. Apelando a la teoría de los actos de habla de John Austin, Butler inserta en los estudios de género el concepto de performatividad según el cual, en tanto práctica reiterativa y referencial mediante la que el discurso produce los efectos que nombra, el género no constituye una construcción cultural que se impone sobre la materialidad del cuerpo o del sexo sino que el sexo, entendido como norma reguladora, obra de manera performativa para constituir la materialidad de

\footnotetext{
${ }^{87}$ Susana Gamba, en su Diccionario de estudios de género y feminismos (2007), resume algunas de las características principales del género de la siguiente manera: "1) es una construcción social e histórica [...]; 2) es una relación social [...]; 3) es una relación de poder $[\ldots]$; 4) es una relación asimétrica: si bien las relaciones entre mujeres y varones admiten distintas posibilidades [...] en general éstas se configuran como relaciones de dominación masculina y subordinación femenina; 5) es abarcativa [...] 6) es transversal [...] 7) es una propuesta de inclusión $[\ldots]$; 8) es una búsqueda de una equidad que sólo será posible si las mujeres conquistan el ejercicio del poder en su sentido más amplio" (121).

${ }^{88}$ Un abordaje importante acerca de las deudas y críticas que la obra de Butler mantiene con la de su antecesora francesa como así también con otras feministas destacadas como Julia Kristeva es el libro Sobre sujeto y género. Lecturas feministas desde Beauvoir a Butler (2000) de María Luisa Femenías. En este trabajo, Femenías afirma que Butler fundamenta sus críticas a Beauvoir en tres supuestos: "En primer término, considera [...] que "sujeto" y "varón" se superponen. Esto la lleva a mezclar aspectos extensionales e intencionales de la noción de sujeto hasta convertirlo en un imposible para las mujeres. En segundo lugar, rechaza de plano las corrientes que fundan la cultura en la institución normativizadora y compulsiva de la diferencia sexual (A. Rich), que considera deificada y dependiente de la metafísica de la sustancia, un resabio esencialista y ontologizante. [...] En tercer término, sostiene que el cuerpo, incluido su sexo, es un constructo; razón por la cual la categoría de género es superflua o redundante. Como resultado, Beauvoir no habría escapado a la trampa falogocéntrica" (188).
} 
los cuerpos y de las diferencias sexuales en pos de la heterosexualidad (2002: 18). En tal sentido, el género no es una identidad estable sino formada en el tiempo e instaurada en el espacio mediante la reiteración de actos que estilizan el cuerpo creando la ilusión de un yo constante. Si estos actos, como distintas formas en que un cuerpo crea su significación cultural, son performativos, se puede afirmar, entonces, que no existen atributos preexistentes sobre los cuales puedan establecerse criterios de verdad o falsedad por lo que la identidad de género se revela como ficción reguladora (Butler 2007: 173-5) que en la práctica puede no estar en consonancia con la bipolaridad que pretende imponer el sexo.

Sin embargo, el género constantemente disimula este acto de crearse como géneros diferenciados y refuerza su aparente naturalidad mediante la sanción que sobreviene a su transgresión. Dicho de otra manera, el sexo no es algo que uno tiene o es, no es un dato corporal puro o dado sino una norma que califica al cuerpo, le da viabilidad y visibilidad mediante una dinámica de poder que se instituye en la reiteración performativa del discurso y que implica un proceso mediante el cual el sujeto asume y se apropia de esa norma y, con esto, se identifica en función de ciertos imperativos sexuales que excluyen otros y que, en consecuencia, producen abyección $^{89}$.

Necesaria para circunscribir la esfera de los sujetos, constitutiva de sus límites en tanto demarca el terreno de las identificaciones, la abyección designa los espacios "inhabitables" de la vida social y amenaza con

\footnotetext{
${ }^{89}$ Para una revisión pormenorizada de los diferentes matices que imprimen a la noción Butler y Kristeva ver el trabajo de Tesis Doctoral de Silvana Mandolessi "La abyección como categoría analítica en la obra de Witold Gombrowicz". Tesis Doctoral. Lovaina, 2009.
} 
romperlos en virtud de su precariedad e inestabilidad (21). Por tanto, la abyección como categoría que inviste lo excluído y acecha, intimida, acosa lo incluido constituye un dispositivo político de envergadura que tanto designa en términos positivos como negativos. Quiero decir con esto que, así como, según Bejel, la construcción de la abyección en torno de la figura de los homosexuales fue una estrategia política de constitución de la nación cubana implementada por el gobierno postrevolucionario de Fidel Castro, que implicó la censura y persecución del grupo considerado abyecto, para Butler la abyección puede ser una estrategia política que permite "rearticular los términos mismos de la legitimidad simbólica y la inteligibilidad" (21). En este sentido, entiendo que en Sarduy esta es una posición de enunciación mediante la cual construye una narrativa disidente con el poder castrista que lo excluyó de los cánones de la literatura nacional y que, aún más, me arriesgo a predecir, de haber permanecido en la isla, es probable que lo hubiera incluido en la lista de los homosexuales abyectos, censurados y perseguidos $^{90}$.

\footnotetext{
${ }^{90}$ En este sentido Sarduy confiesa, en una carta dirigida a Roberto González Echevarría en mayo de 1972, "todo trauma tiene una solución catastrófica: la nuestra — la tuya — sería de tipo regresivo, con las tres connotaciones más a la mano de la palabra: regreso a la islaclaustro materno. etc., regreso físico e intelectual y conducta de tipo reaccionario, en cierto modo. No es la pequeña agitación revisionista, catolizante, moral y pequeño-burguesa, el reino de los arribistas y mediocres instalado en Cuba lo que puede responder a la inquietud radical, coño, que padecemos. Se trata de cambiarlo todo, desde el modo de pensar hasta el de mamar; y esto no es una boutade. Todo: y eso no va a pasar hasta que algo no estalle adentro -otra vez el lirismo metafísico!- No sé. Tenemos que hablar" [Itálicas en el original] (1999: 1588).
} 


\section{2. Cuerpo abyectado: la escritura del exilio en}

\section{Maitreya}

¿Cómo termina, y cuándo, el exilio? Quizás el último de los espejismos consista en creer que termina con un regreso a la tierra natal. $Y$ es que nada recupera al hombre de algunas palabras escuchadas, y nada redime a quien las dijo. Exilado de mí mismo, ausente de una parte de mi propia escucha, de algunos sonidos, de una frase. Sólo el silencio puede responder a esa mano levantada, agitándose, alejándose en el puerto, ya perdida, diciendo "Adiós".

Severo Sarduy, Exilado de sí mismo (1990)

Un espectro amenaza Europa: el espectro de los disidentes. Decir la singularidad de los inconscientes, de los deseos, de las necesidades. Poner en juego las identidades $\mathrm{y} / \mathrm{o}$ los lenguajes de los individuos y de los grupos. Devenir el analista de los conjuntos sociales como imposibles: de los discursos homogéneos y de las instituciones consagradas como imposibles. Afirmarse como revelador de lo Imposible.

Julia Kristeva, "Un Noveau Type

D’Intellectuel: Le Dissident” (trad. de

Manuel Asensi Pérez)

Severo Sarduy se fue a París en 1959, después del triunfo de la Revolución, pero no como un exiliado disidente con la causa sino, por el contrario, becado por el gobierno de Fidel Castro para hacer su tesis de arte en la Escuela del Louvre. Entonces comenzó un periplo que, si bien geográficamente tendría pocos desplazamientos —antes de París, desde Camagüey a La Habana, y después, frecuentes pero ocasionales viajes-, lo llevaría por derroteros cuyas implicancias tendrían que ver, principalmente, 
con aspectos personales y artísticos que no se ciñen a la mera experiencia sino que dan lugar a una escritura con profundos cuestionamientos políticos.

En "Exiliado de sí mismo" (1990) —un texto clave porque en él explicita ideas que en sus obras narrativas quedan en el nivel de lo entredicho- Sarduy construye una imagen del exilio que es propia y particular de la literatura y, diría más, de la intelectualidad latinoamericana. En ella, es la puerta giratoria de un café el límite que se impone entre un afuera francés y un adentro que no se sabe con exactitud cuál será hasta no haberla transpuesto, porque puede ser un Buenos Aires con Cortázar o un Virgilio Piñera traduciendo a Gombrowicz o por qué no, el mismísimo Rubén Darío. Lo cierto es que, según Sarduy, los escritores latinoamericanos no se exiliaron ni a Francia ni a París sino a uno de sus barrios -el Barrio Latino- y a dos o tres de sus cafés, con lo que "Entrar pues a ese exilio [...] es, de cierto modo, anularlo" (Sarduy 1999 [1990]: 41) porque el verdadero exilio es lingüístico, no físico, y es el salto que se produce cuando se deja el idioma, para adoptar el francés, en algunos casos, o para volver al pasado más recóndito del castellano, en otros. Entonces este exilio crea comunidades, generaciones, continuidades, crea contracánones que funcionan, en cierto sentido, como un canon: "Llegar pues [...] a este exilio, voluntario o no, es al mismo tiempo abrazar una orden, integrarse: aceptar también, y eso es lo más duro, como la delegación de una continuidad, no puedes ser indigno de los de antes, tienes que escribir como ellos, o mejor" (42). 
Pero Sarduy parece no entrar en ninguna de estas "comunidades" "91. Él no se considera un exiliado sino un "quedado, o si se quiere, procedo de una isla-, un a-islado.", alguien para quien el alejamiento de su tierra es circunstancial y la permanencia fuera de ella más que una determinación es una consecuencia inevitable de la propia indecisión que no tiene implicancias de trascendencia y que, por lo tanto, puede ser revertida sin más. Sin embargo, tampoco forma parte del canon: "Recientemente me llamó un amigo para comunicarme la infausta noticia de que yo "no existía", al menos en los anales recientes de la literatura nacional" (43) por lo que, si efectivamente son sólo las antologías — “redactadas por celosos guardianes del patrimonio literario nacional" - las encargadas de dar cuenta de estos "partidos", ni siquiera en este sentido Sarduy puede ser considerado un exiliado en el sentido tradicional del término ${ }^{92}$. Por el contrario, es un

\footnotetext{
${ }^{91}$ González Echavarría se refiere al exilio de Sarduy como un "exilado a la segunda potencia". Por un lado, porque él mismo encarnaba la mezcla racial y cultural representativa de la nación cubana en tanto constructo todavía en vías de integración debido a la diversidad de elementos culturales que, recién llegados a Cuba, todavía pueden considerarse exiliados. No hay más que recordar, en este sentido, que la historia de colonización incluye a los negros incorporados violentamente en el siglo XVI, a los chinos desde 1848, también sumados en condiciones poco felices y a los indios que prácticamente fueron exterminados. Por otro lado, porque en el París de los años sesenta, los demás exiliados latinoamericanos se concentraban en una especie de "supranacionalidad continental" forjada en torno a la Cuba revolucionaria sobre la cual Sarduy tenía sus críticas y reparos aunque no expresados públicamente. En carta personal dirigida González Echevarría en diciembre de 1976 Sarduy afirma con su tono jocoso e irónico habitual: "Cuba es ahora un país electoral, aunque por supuesto todos los candidatos son designados por el gobierno, y Castro, en esas elecciones y en las previsibles modificaciones legislativas, "salió" presidente de la República, Primer Ministro, Secretario del Partido, y por qué no, reina de belleza Palmolive" (1999: 1589).
}

92 En febrero de 1994 - a tres años del ensayo sarduyano y uno después de su muerte y cuando ya había pasado gran parte de su vida fuera de Cuba- Virgilio López Lemus, poeta, ensayista, crítico e investigador literario cubano pronunciaba una conferencia en la Feria Internacional del Libro de La Habana en lo que fue el primer homenaje en Cuba a Severo Sarduy. En este texto, López Lemus afirma: "Por todo ello, y por mucho más, Severo Sarduy ha retornado a Cuba. Sus escritos comienzan a abrirse paso entre nosotros para ocupar el sitio que le pertenece al autor por su infatigable trabajo como creador, próximo a Alejo Carpentier y a José Lezama Lima, cercano a Nicolás Guillén y a Eugenio Florit, junto a Dulce María Loinaz, a Samuel Feijóo, a Gastón Baquero, a Eliseo Diego y a Virgilio Piñera. Los grandes todos acuden ahora a saludarlo en su reingreso definitivo en la 
excluido del campo cultural cubano posrevolucionario, un a-islado en la literatura latinoamericana del exilio... Y un "exiliado de sí mismo" porque, se pregunta: "El verdadero exilio, ¿no será algo que está entre nosotros desde siempre, desde la infancia, como una parte de nuestro ser que permanece obscura y de la que nos alejamos progresivamente, algo que, en nosotros mismos es esa tierra que hay que dejar?" (42)

Exiliarse, entonces, como una tierra que hay que dejar, como una falta que produce sentido, que produce escritura, construye genealogías, parentescos, filiaciones, adhesiones y divergencias. No es un exilio de aplastante fijeza sino un estado de inestabilidad, movimiento e inquietud. Es el exilio que trasciende el significado geográfico y por el cual el sujeto es un exiliado de su tierra, su historia, su tiempo, pero también, de su cuerpo, de sí mismo. De este modo, se transforma en un concepto de profunda connotación política en tanto se asume como una postura de disidencia y marginalidad que impregna y condiciona todos los órdenes de la vida.

Derivada del latín exilium -vocablo utilizado por los romanos para designar el destierro impuesto como castigo- la palabra exilio ha sido empleada, a la luz de los acontecimientos históricos del siglo XX y en la mayoría de los casos, para explicar los procesos que implican el alejamiento, casi siempre obligado, de los sujetos de su lugar de origen por causas políticas ${ }^{93}$. Así es visto, por ejemplo, por críticos que abordan la

Isla que con él y con su obra asume un importante componente de la nacionalidad, ya innegable" (1997:90).

${ }^{93}$ Algunos conceptos que en primera instancia pueden ser similares al de exilio son la noción de "migrancia" de Antonio Cornejo Polar y "nomadismo" de Rossi Braidotti.

En la última etapa de su obra crítica, Cornejo Polar hizo girar sus análisis en torno a las categorías de "migrancia" y "sujeto migrante". En el artículo "Tradición migrante e intertextualidad multicultural: el caso de Arguedas" Cornejo utiliza la obra del autor peruano como ejemplo para desarrollar con profundidad la noción de sujeto migrante a la 
literatura y eligen su corpus de trabajo teniendo en cuenta la condición de exiliados en las que produjeron los autores ${ }^{94}$.

que compara y opone con la de sujeto mestizo aunque, advierte, una no desplaza a la otra sino que, por el contrario, la engloba en un proceso individual y colectivo que pone el énfasis en el movimiento y, en consecuencia, en la historia. Cornejo entiende el migrar como "nostalgiar desde un presente [...] las muchas instancias y estancias que se dejaron allá y entonces lo que produce una acumulación de tiempos y experiencias (48) que no implica síntesis sino que pone énfasis en esta multiplicidad de tiempos y espacios. La norma es, por lo tanto, la fragmentación (49).

Más relevante que lo anterior, en mi opinión, es que la condición migrante, más que una característica psicológica o experiencial, implica un locus de enunciación a partir del cual se produce un empleo diferenciado del lenguaje. Esto le confiere un espesor político que me interesa destacar en tanto remite a la constitución de un sujeto disgregado, difuso y heterogéneo que asume como una de sus principales particularidades la conformación mediante discursos encabalgados en varias culturas, conciencias e historias, que yuxtaponen lenguas y sociolectos, y que, por lo mismo, conllevan una dinámica centrífuga que reivindica la vigencia múltiple del aquí y el allá, el ahora y el ayer (50-1). Es un habla emitida de manera transitoria y desde cualquiera de sus lados y que, por esta razón, implica la falta de un eje centrado y fijo que repite la condición peregrina del migrante. Es el discurso, entonces, de un sujeto desplazado que, a diferencia del discurso mestizo, constituye los términos de un diálogo siempre abierto e inconcluso y cuya figura preferencial no es la metáfora sino la metonimia (52).

Braidotti, en cambio, adopta la noción de "nómade"en tanto la entiende como contraria a los conceptos de "exiliado y migrante" — a ambos los define en un sentido más literal del término - ya que ni representa la falta de un hogar ni el desplazamiento compulsivo sino la figuración de un sujeto que ha renunciado a toda idea, deseo o nostalgia de lo establecido. Se trata de una identidad hecha de transiciones y desplazamientos que, si bien no responde a una unidad esencial, tampoco está totalmente desprovista de unidad ya que su modo es el de ciertos patrones categóricos que se fundan en una cohesión lograda a fuerza de repetición, "movimientos cíclicos" y "desplazamientos rítmicos" (2000: 58). La conciencia nómade es una posición epistemológica pero además, y por esto mismo, es también "una forma de resistencia política a las visiones hegemónicas y excluyentes de la sociedad" (59) por lo que la figura del nómade habilita la dispersión y diseminación de ideas (60).

En mi opinión, no se puede establecer una relación de comparación entre los tres conceptos porque se trata de tres fundamentos epistemológicos radicalmente diferentes entre sí. Sin embargo, y por tratarse de una preocupación común que consiste en el intento por darle cierta definición a un tipo de sujeto que ya no entra en los parámetros del cartesianismo, creo que sí se pueden establecer ciertas vinculaciones por las cuales considero que la noción de "sujeto exiliado" o "exiliado de sí mismo" que pretendo desarrollar en este trabajo tiene mayores acercamientos a la de "sujeto migrante" que a la de "nomadismo". Una de las razones fundamentales es que, al menos de lo que se desprende del análisis de Braidotti, no parece haber en este último concepto el sentimiento de conciencia desgarrada que sí se percibe en los otros dos y que hace a la diferencia de una teoría producida desde la conflictiva -y dolorosa, el "trauma" que empezó con la conquista- realidad latinoamericana, aunque, se me objetará, en el caso de Sarduy no sea ése el espacio físico de producción.

Ricardo Llamas y Javier Vidarte toman el concepto de "nomadismo" de Braidotti como una forma de conceptualizar el posicionamiento de la labor intelectual de los estudios gays, lésbicos y queer o teoría torcida en Homografías. Madrid: Espasa Calpe, 1999.

94 Para el caso de la literatura argentina, es paradigmático en este sentido el trabajo de José Luis de Diego, ¿Quién de nosotros escribirá el Facundo? Intelectuales y escritores en Argentina (1970-1986) (2001) ya que en él aborda un período que tiene al exilio como una de sus características principales. De Diego asume aquí que la palabra está marcada, en algunos casos, como "el resultado de un deseo de eludir una probable decisión judicial y, en 
Sin embargo, otros abordajes imprimieron al concepto un sentido más amplio y enriquecedor logrando construir, de este modo, una clave para pensar otras situaciones que, si bien no están necesariamente marcadas por el distanciamiento geográfico, obligado y político, sí se pueden caracterizar como signadas por el exilio.

Este es el caso del teórico Edward Said quien en Representaciones del intelectual (1996) toma la noción de exilio para caracterizar la relación que, según él, deben establecer los intelectuales con el poder. La tesis de la cual parte presupone un intelectual que asume el papel público de "francotirador", de perturbador del status quo, y una de cuyas principales obligaciones consiste en buscar una independencia relativa con respecto a las presiones del poder. Teniendo en cuenta los presupuestos gramscianos, Said profundiza en el rol social de los intelectuales atribuyéndoles representatividad no sólo en el ámbito de lo social, sino en un estilo de vida y un comportamiento que les son específicos. Dicho de otro modo, el intelectual es un individuo que tiene la facultad de representar, encarnar y articular un mensaje, una actitud o una filosofía para y en favor de un público (29-30) y que, fundamentalmente, ha apostado no a las fórmulas

todos, tiene un fundamento de orden político y no siempre descansa sobre una decisión individual" (154). Sin embargo, de Diego reconoce por los menos dos usos de la palabra exilio: uno literal, que alude al significado ya mencionado, y otro metafórico que lo amplía en tanto implica no solo el "estar en el exilio", es decir, fuera de un territorio con sus consabidas consecuencias lingüísticas, simbólicas y cotidianas, si no también el "sentirse en el exilio" esto es, fuera de un sistema, de una cultura y de una comunidad (154). De esta manera, escribir puede constituir una forma de sustitución de una pérdida pero también es una condición inherente a la función del escritor, en tanto si la lengua es la patria, el hogar y la ley para todo ser hablante, para el escritor que establece una relación con el lenguaje de profunda conciencia, es la posibilidad de situarse en el límite de dos esferas: la de la estructura social en que vive - "la patria exterior"- y la de lo que hace o se propone hacer en la suya propia (155). Para el contexto cubano, Ambrosio Fornet (2001) ha elaborado un glosario de términos afines. 
fáciles o estereotipadas sino al sentido crítico (40). El intelectual no está para contentar a su audiencia sino, por el contrario, pretende suscitar perplejidad, mostrarse contrario y displicente; es el autor de un lenguaje sobre el cual es indispensable que sepa intervenir y que se esfuerza por hablarle claro al poder. De esta manera, Said apela al sentido metafórico de la palabra exilio con el objetivo de ampliar su trabajo desde la historia social y política de emigraciones hacia la caracterización de esta actitud crítica -política, en consecuencia- del intelectual por lo que, si bien el concepto mantiene su significado original relacionado con el desplazamiento territorial involuntario, se carga de un plus de sentido que trasciende al anterior. Desde esta perspectiva si los intelectuales integrados son aquellos que pertenecen plenamente a la sociedad tal como es, sin dar cuenta de posibles disensos; los que, por el contrario, asumen el desacuerdo con esa sociedad como una forma de posicionarse - no frente a las circunstancias sino frente a la vida- se constituyen como marginales o exiliados frente al poder que representa esa sociedad. Estos últimos son, en opinión de Said, los que verdaderamente asumen el papel del intelectual moderno, es decir, el de poner en discusión las normas dominantes en tanto éstas están fuertemente vinculadas con la nación como entidad triunfalista y autoritaria, encargada de dictar ella misma estas normas.

Pero también son exiliados frente a los privilegios y honores que a la condición de intelectual suele corresponder. El exilio para el intelectual, según Said, es inquietud, movimiento, estado de inestabilidad permanente que tiene como función desestabilizar a otros. Es la imposibilidad de retroceder a una posición anterior pero, aún más, la de llegar a sentirse 
plenamente a gusto en la nueva situación. El intelectual exiliado se siente feliz en su condición de infelicidad, de tal manera que la insatisfacción se convierte en estilo de pensamiento, en una especie de morada temporaria, en una postura política -agrego- que consiste en no dejarse reposar en ningún lugar fijo, en mantenerse en suspenso y alerta para que ese estado de turbación no se convierta en una rígida posición ideológica: "El intelectual exílico no responde a la lógica de lo convencional sino a la audacia aneja al riesgo, a lo que representa cambio, a la invitación a ponerse en movimiento y no a quedarse parado" (73).

Para Said, esto constituye uno de los privilegios exclusivos del intelectual exiliado que es el de poder ver todo en una doble perspectiva: la de lo que se dejó en el pasado y la de aquello que lo rodea en el presente, es decir, se instaura una mirada que se cuela desde esa posición de permanente movilidad $^{95}$. Los otros privilegios señalados por Said no son más que una consecuencia de estos. Por un lado, el placer de sorprenderse por no dar nada por asegurado; por el otro, la capacidad para analizar la realidad no como es sino como ha venido a ser, es decir, como el resultado de una serie

\footnotetext{
${ }^{95}$ En 1988 Julia Kristeva publicó un texto que permite leer ciertas conexiones con el ensayo sarduyano en torno a la idea de "exiliado de sí mismo" en tanto entiende la enajenación de sí mismo como la posibilidad, dolorosa por cierto, de obtener la distancia necesaria para imaginar y pensar la propia cultura. En Étrangers á nous-mêmes, Kristeva afirma: “'Je est un autre" de Rimbaud n $\square$ était pas seulement $1 \square$ aveu du fantôme psychotique qui hante la poésie. Le mot annonçait $1 \square$ exil, la possibilité ou la nécessité $\mathrm{d} \square$ être étranger et de vivre à $1 \square$ étranger, préfigurant ainsi $1 \square$ art de vivre $\mathrm{d} \square$ une ère moderne, le cosmopolitisme des écorchés. L $\square$ aliénation à moi-même, pour douloureuse qu $\square$ elle soit, me procure cette distance exquise où $\mathrm{s} \square$ amorce aussi bien le plaisir pervers que ma possibilité $\mathrm{d} \square$ imaginer et de penser, $1 \square$ impulsion de ma culture. Identité dédoublée, kaléidoscope $\mathrm{d} \square$ identités: pouvons-nous être à nous- mêmes un roman- fleuve sans être reçus comme fous ou comme faux? Sans mourir de la haine de $1 \square$ étranger ou pour 1 $\square$ étranger" (25). En tal sentido, es notable cómo sin compartir afiliaciones académicas ni teóricas Kristeva parece prefigurar las palabras de Said por lo que se hace indispensable pensar que es la misma experiencia del exilio la que provoca cierto productivo modo de pensar en algún punto común a ambos autores.
} 
de acontecimientos históricos no necesarios sino contingentes, de alguna manera, opcionales que forman parte de determinaciones tomadas por seres humanos, y por lo tanto, evitables o, por lo menos, transformables, y no como hechos naturales o sobrenaturales irreversibles (71).

Por su parte, imbuido del contexto de Tel Quel - postestructuralismo y psicoanálisis en primera medida - la noción de exilio para Sarduy adopta connotaciones más profundas y particulares que agregan un plus de sentido a las señaladas por Said en tanto atañe a cuestiones fundamentales en relación con la problemática de la subjetividad como construcción discursiva y que, si bien no se plasma en una teoría explícitamente formulada, sí se puede advertir en algunos de sus ensayos, y puesta en práctica de escritura en su obra narrativa, por ejemplo, tal como veremos en adelante, en Maitreya (1978).

El lenguaje del exilio es el lenguaje que elide pero también alude. El que asume la superabundancia y el exceso, el goce y el desperdicio por lo que, en este mismo procedimiento fetichista, se instaura a sí mismo en el lugar de la carencia, señala la falla que no puede suturar, se arroga el lugar de marginalidad y la exclusión desde el cual pone en discusión el propio lenguaje del poder, de la autoridad, del autor...

Por eso es, también, el lenguaje del exiliado, del "abyectado" en palabras de Julia Kristeva (1980), en tanto entiende que "aquel en virtud del cual existe lo abyecto es un arrojado (jeté), que (se) ubica, (se) separa, (se) sitúa, y por lo tanto erra en vez de reconocerse, de desear, de pertenecer o rechazar" (16). Lo abyecto no implica preguntarse por el "ser" sino por el lugar ya que el espacio que preocupa al arrojado no es uno, ni homogéneo, 
ni totalizable sino divisible y plegable. El arrojado es un constructor de territorios, de lenguas, de obras que no cesa de delimitar su universo "cuyos confines fluidos $[\ldots]$ cuestionan constantemente su solidez y lo inducen a empezar de nuevo" (16). Un arrojado, un errante, un abyecto o, como afirma Sarduy, el exilio es también borrar la marca del origen "pasar a lo obscuro donde se vio la luz", es develar el espejismo que consiste en creer que el exilio termina con el regreso a la tierra natal (1999 [1990]: 43).

Elemento clave en la dinámica de constitución del sujeto borderline, lo abyecto no es un objeto factible de ser nombrado o imaginado sino que de éste sólo tiene una cualidad, la de oponerse al yo ya que hay en la abyección una rebelión del ser contra aquello que lo amenaza. Lo abyecto es algo rechazado de lo que uno no se separa ni se protege de la misma manera que de un objeto, es aquello que perturba una identidad, un sistema, un orden. Aquello que no respeta los límites, los lugares, las reglas porque la abyección se construye sobre el no reconocimiento de sus próximos. Entonces, la abyección se sostiene como lugar de otro hasta el punto de procurarle un goce para el borderline, ya que, mientras que éste exige una ausencia de la identidad, el advenimiento de una identidad propia exige una ley que mutile: "Exilado de mí mismo, ausente de una parte de mi propia esencia, de algunos sonidos, de una frase" (43).

Toda abyección, por lo tanto, es reconocimiento de la falta fundante de todo ser, sentido, lenguaje, deseo, por lo que la abyección de sí es la forma de esa experiencia por la cual el sujeto descubre que todos sus objetos se basan en la pérdida originaria de su propio ser. Es decir, si pensamos que la experiencia de la falta misma es anterior al ser y al objeto "entonces se 
comprende que su único significado sea la abyección, y con más razón la abyección de sí, siendo su significante... la literatura" (Kristeva 12). "Sólo el silencio puede responder a esa mano levantada"-agrega Sarduy (43) —...y la literatura es, entonces, significante que pone en evidencia esa falta constitutiva del lenguaje que sólo puede ser dicha por el silencio... o el exceso, la elipsis y el goce, el exilio, lo inquietante. Es, como la abyección, perturbación del orden y las reglas que no tiene que ver con la ausencia de limpieza o de salud que implica lo que está del otro lado del límite, sino con aquello que está en el límite que lo invade todo hasta convertirse en objeto.

Como para Kristeva, entonces, la literatura contemporánea es el significante de lo abyecto, emparentado con la perversión pues no abandona ni asume una interdicción sino que la desvía; es decir, demuestra la imposibilidad de la Ley y la autoridad, las usa y las deforma pero a la vez, se distancia de lo abyecto, se imagina su lógica, la introyecta y, en consecuencia, pervierte la lengua (25). Es una literatura que trasvasa las categorías de lo Puro y lo Impuro, de lo Interdicto y del Pecado, de la Moral y lo Inmoral, una escritura que forma parte del intervalo que caracteriza a la perversión y que provoca lo abyecto (26).

Así, abyección, neobarroco, inquietud en Maitreya son claves de lectura que funcionan como significantes que proliferan en torno a un significado obliterado, elidido, diferido, de alguna manera, opacado: el exilio físico, real, simbólico, corporal... en todos los casos, político. Esta característica le permite afirmar a Roberto González Echevarría que "Maitreya es la novela del exilio" por lo que "tiende un puente metafórico entre lo sucedido en el Tíbet y lo ocurrido en Cuba" (1987: 175). La 
comparación remite a los sucesos acaecidos después de la invasión china en octubre de 1950. Aunque desde entonces el Dalai Lama, ocupando un puesto de poder que en realidad seguía sometido a los generales chinos, intentó suavizar la invasión, en marzo de 1959 una rebelión oriental del Tíbet se extendió hasta la capital y provocó una represión feroz que terminó con el exilio hacia la India del Dalai Lama y una gran cantidad de sus adeptos. Coincidentemente, también hacia marzo de 1959, el exilio cubano hacia Miami había comenzado como reacción a la Revolución que se instauraba en el poder desde enero del mismo año: "Me voy de esta isla, aunque sea aferrado a un tronco de pino, la marea lo llevará hacia el norte" (Sarduy 1999 [1978]: 613).

Y con esta situación de exilio, precisamente, se abre la novela. Al comienzo de Maitreya se cuenta la muerte de un lama en un monasterio de las montañas del Tíbet en el cual ya se escuchan los disparos de los fusiles chinos por los que los monjes se ven obligados a huir a la India luego de quemar el cadáver del maestro pero con la esperanza de que la predicción de renacer, hecha poco antes de morir, sea cumplida. Así se produce, en esta primera parte, un procedimiento escritural que bien señala González Echevarría y que consiste en urdir el texto en torno a una figura tutelar ausente hasta que, en la India, los monjes encuentran un niño cuidado por dos chinas - las hermanas Leng- que por algunos indicios y por las pruebas a las que lo someten, se comprueba que es la reencarnación del Lama $(175)^{96}$. Pero las Leng raptan al niño y atravesando la India en tren se

\footnotetext{
${ }^{96}$ Esta estrategia le permite a González Echevarría comparar Maitreya con El siglo de las luces (1962) de Alejo Carpentier y Paradiso (1966) de José Lezama Lima en las que las ausencias corresponden al padre de los protagonistas y al Coronel José Eugenio Cemí,
} 
lo llevan a Ceilán donde, convertido en un sacerdote budista, se transforma en la atracción de un hotel que las hermanas fundan hasta que él mismo decide marcharse primero rumbo al mar y después al monte junto a unos monjes que allí encuentra. Cuando regresa, se niega a seguir respondiendo las preguntas de los clientes por lo que Iluminada Leng, una sobrina de las hermanas aparecida en escena poco antes, y el Dulce, su compañero, viendo el final del negocio, se van a Cuba al tiempo que el Instructor muere y es sometido a un ritual funerario de características similares al del maestro en la primera parte de la novela. Aquí inician un peregrinaje por lugares cuyas geografías, aunque no del todo precisas, remiten al mismo que debieron realizar los revolucionarios cubanos hasta la entrada triunfal en La Habana: "Recorrieron la isla de oriente a occidente, solos o en pequeñas bandas manigüeras, seguros de albergar una verdad sin violencia, capaz de liberar instantáneamente hasta un paria o un puerco" (623).

En Sagua la Grande, una ciudad cubana famosa por albergar una importante colonia china, se encuentra Luis Leng, hijo de Iluminada y el Dulce, quien seduce a las Tremendas, mellizas nacidas en la ciudad con facultades adivinatorias y que pierden con la primera menstruación por lo que deben dedicarse al canto y la representación. Pero este escenario cambia repentinamente porque la escena se traslada a Miami, después de la Revolución, donde se encuentran las Tremendas, Luis Leng y un personaje recién aparecido que se presenta como el enano pintor sagüero quien, de aquí en más irá cobrando relevancia en el relato hasta ser enterrado en el final. Aquí, las mellizas comienzan la práctica del fist fucking que 
conservarán hasta el desenlace cuando una de ellas concebirá y parirá un "engendro" por el ano lo que constituye, en mi opinión una de las construcciones de la abyección más importantes de la obra. Finalmente, un argumento plagado de mudanzas: de Miami a New York, de ahí a Oriente Medio y, después del nacimiento y entierro del engendro junto al enano sagüero, el último exilio, el de la Tremenda - la Divina, su par mellizo había sido desinflada por su hermana a causa de los celos-, hacia Afganistán.

Como vemos, no es erróneo pensar con Echevarría que Maitreya es la novela del exilio. Pero más allá de la categoría geográfica, existe también el exilio como elemento constitutivo de la subjetividad que involucra las nociones de lo corporal, la sexualidad y el lenguaje. En Maitreya - y en toda la obra sarduyana- son éstas tres nociones que operan a nivel discursivo como dispositivos que ponen en evidencia la construcción fragmentaria, contradictoria y problemática del sujeto. En este sentido, Gustavo Pellón afirma que en Cobra y Maitreya Sarduy emplea una técnica estilística que supone la interrupción irónica del fluir de la narración a nivel de la oración por medio de la cual la superficie del texto es constantemente minada y que remite al lector al carácter arbitrario de la expresión y al universo novelístico que el autor crea o subvierte (1983: 7-8). La “indecisión paradigmática”, así es como llama Pellón a la técnica mencionada, constituye entonces un vehículo fundamental de la estrategia narrativa que intenta rechazar la asignación de un significado último del autor al lector: "For Sarduy, meaning is always provisional and tentative, and only the corrosive process of irony endures" (8). 
Para Pellón, esta predominancia de la crisis interpretativa en la escritura de Sarduy refleja el proyecto central de la ideología del postestructuralismo que implica la renuncia al poder de la autoridad y el destronamiento del concepto de identidad fija. En mi opinión, esto constituye, además, otro punto en común con el neobarroco sarduyano ${ }^{97}$.

Por su parte, el cuerpo se instituye en un enclave fundamental de la lógica de la abyección ya que, tanto vivo como muerto, se encuentra excluido del campo de lo sagrado y, por lo mismo, de los ritos y límites de la "pureza" en el que la tradición judeo-cristiana lo enmarcó. Así, en la vida se presenta por fragmentos sobre los que se va fijando la atención como con piezas dispersas de un rompecabezas que, lejos de constituirse en la fantasía de una unidad corporal, se mantiene en la incertidumbre de no saber cuál es, si es que hay, la figura central ni si se podrá rearmar: "Las manos pálidas, de largos dedos unidos, estrechaban sobre el pecho libros de hojas quemadas. Los ojos: vacíos, o retocados" (607). Cuando la escena sí cobra sentido, la abyección puede estar en las infusiones que ingieren — saliva y orina- o en la narración descarnada de un acto sexual anal, sadomasoquista (647), del que nacerá por el ano, también en un acto que más se parece a una representación abyecta que a un parto, el "engendro":

Agarrada al árbol plástico, lleno de frutas diversas y abrillantadas, y de pajaritos trinadores, de pie, la Tremenda dio un gran pujo. Sobre una colcha de hilos blancos y negros, restos de un tapiz iranio, cayó parado, como sobre una flor de loto, la mano

\footnotetext{
${ }^{97}$ En el mismo sentido, Suzanne Jill Levine adopta el concepto de "desplazamiento", según la definición que le otorga Umberto Eco, para caracterizar la escritura de Sarduy en Maitreya. En tanto procedimiento que altera códigos o géneros establecidos, que distorsiona o parodia modelos tradicionales, el desplazamiento en la novela, según Levine, produce traducción, copia, que fragmentan la ilusión auto-reflexiva de un yo monolito pero al mismo tiempo crean otra ilusión espejeante que parodia el proceso creador del "original" (1991: 311-5).
} 
derecha alzada y abierta, sonriente y rojo, como de sangre fresca o de porfirio, el engendro tramado por el enano (685).

Pero lo abyecto también está en el cuerpo corrompido, purulento, hinchado, en "los pies rajados" o las "manos con manchones de coágulos" (636), en el cuerpo que bordea la muerte o en la muerte misma la que, fuera nuevamente de los rituales de sociabilidad, se transforma en el cadáver infecto, sometido a todo tipo de escarnios y vejaciones: "con tabletas de sándalo en forma de cuchillo raspaban, de un cadáver, las viruelas; con una lima, le desgastaban los dientes; sobre los párpados duros, le pegan círculos de metal con cuadrados vacíos en el centro: brotaba abultada la piel, entre ideogramas verdosos" (596). Es el cadáver que, sin Dios y sin ciencia, constituye el colmo de la abyección porque es la muerte infestando la vida, es una "extrañeza imaginaria y amenaza real" que nos llama "y termina por sumergirnos" (Kristeva 11): "La muerte, monitos, no forma parte de la vida, sino al revés: surgimos de lo increado, un abrir y cerrar de ojos, volvemos a él" (Sarduy 1999 [1978]: 590).

Sin embargo, lo abyecto no es, según Kristeva, la ausencia de limpieza o salud sino lo que perturba un orden, un sistema, una identidad y, en este sentido, cuerpo, sexualidad y escritura se anudan en la construcción de un sujeto borderline, de un sujeto abyecto, que no responde a una identidad, un nombre, o un género. El cuerpo escrito, tatuado, pintado tiene, en Maitreya, la función de simular y disimular al mismo tiempo: "Para que la abandonaran, despistando por exceso, montada en un andamiaje de hilos invisibles, fingiría la fijeza total y la muerte [...] sería una gran mariposa opulenta" (662). El sexo narrado o reflejado en la superficie tersa de un espejo rompe los límites de lo naturalizado y pone en jaque las 
convenciones sociales sobre las que descansan los pilares fundamentales de la burguesía moderna.

La escritura, por su parte, se instituye en la condición de toda existencia porque es la escritura sobre el cuerpo —en tanto tema y en tanto soporte- pero también porque es la escritura sobre el sujeto, el del enunciado, el de la enunciación y el sujeto escribiente, el que se inmiscuye en el relato, el que lo organiza a su antojo y deliberadamente deja las huellas de su paso. Es el sujeto acerca del cual la pregunta no es por su "ser" sino por su lugar porque es un sujeto obliterado en las múltiples apariciones y transformaciones de los personajes, proliferante en la heterogeneidad de las voces que superponen relatos y versiones, posiciones de enunciación con instancias del enunciado. Es el sujeto cuyo relato principal es el de la escritura autorreflexiva que por hablar de sí misma — significante pero también, reverso del espejo lacaniano-, funciona como deconstructora de la Imago del organismo como tal y en relación con su realidad y pone en evidencia el proceso constructivo de la subjetividad desde un estadio de fragmentos inarticulados hasta una fantasía de sujeto. Por lo que se instituye, entonces, en el sujeto excluido de su propia escritura, el abyectado, el exiliado... y en el sujeto del exilio, el que, fracturándose él mismo en tanto autor y autoridad, construye una literatura de lo abigarrado, de lo elidido, de la inquietud y lo inquietante porque rompe las categorías dominantes de todo orden, de todo sistema, de toda identidad, de toda nación y se sitúa en la perplejidad, en el intervalo y la disidencia.

Pero también, es una escritura del intelectual disidente y marginal quien, alejándose considerablemente del intelectual comprometido sartreano 
de las décadas anteriores, no se instituye sobre las bases de un sujeto unario, orgánico y coherente sino en función de la noción de sujeto en proceso quien "inaugurando una nueva subjetividad y un nuevo cuerpo hace de la excepción, del margen, del exilio y la disidencia, una práctica política fundamental" (Asensi Pérez 2006: 472).

Para Kristeva, este nuevo intelectual se configura en tres tipos fundamentales —aunque en el análisis posterior también incluye a la mujer- que son el rebelde, el psicoanalista y el escritor de una experiencia en la frontera de la identidad cuya lengua viola, pluraliza y convierte en poli-lógica y polivalente a la ley (1977: 5). Una lengua del exilio, que es otra forma de disidencia, porque de lo que se trata es de cambiar de lugar, de país, de familia, de lengua, de cortar los lazos, hasta los más profundos, los de Un Sentido garantizado por un padre muerto: “Car dans l'exil, si du sens existe, rien ne l’incarne, et il ne fait que se produire et se détruire dans le changement d'espaces (géographiques ou de discours)" (7). Porque la lengua, según Barthes (1977) es fascista pero no por lo que impide decir sino por aquello que obliga a decir con lo cual hablar implica una relación de alienación de la que sólo es posible escapar haciendo "trampas" con y a la lengua mediante la literatura (121). La única salida para el autor que después de haber emprendido un combate contra el poder de la lengua fue recuperado por él consiste entonces en "desplazarse u obcecarse" (131). 


\section{3. De los devenires a la política: implicancias de las} subjetividades homoeróticas

Obcecarse, hacerle trampas a la lengua, no asumir el desplazamiento sino hacer de él un instrumento de lucha, de insatisfacción e inquietud. Constituirse en un abyecto, un exiliado de sí mismo, un excluido, hacer de la disidencia una posición de vida. Poner el cuerpo y hacer con él un texto social, cultural pero sobre todo político... así, creo, entiende Sarduy la escritura y en este sentido, asume, en sus obras, problemáticas caras a su biografía pero, aún más, a su tiempo, a su lugar.

Según Leonor y Justo Ulloa, la obsesión por el cuerpo en Sarduy implica un recorrido que nos lleva de la fiesta al dolor y a la melancolía reflexiva que lo pone como centro de cavilaciones filosóficas en las que lo que se analiza es la corrupción y la muerte. Pero también, y por eso mismo, su obra es "una manifestación de su rebeldía" en contra del canon y la interdicción que se configura a través de la manipulación metonímica de lo que, según Lacan, son las imágenes parciales del cuerpo fragmentado. En tal sentido, el cuerpo se despliega en un campo simbólico, metafórico y referente en el cual cumple por lo menos tres funciones:

“1) la de servir como texto escrito, piel o página, donde encontramos una especie de "arqueología de la piel" repleta de huellas, marcas y suturas que nos refieren a su autobiografía; 2) la de concebir partes específicas del cuerpo como textos que se inscriben en otro texto para enriquecer, visualizar, completar y facilitar la percepción del relato que se narra o la de personificar el texto en sí como un cuerpo saturado con trazos legibles, y 3) la de encontrar en el cuerpo un motivo para profundas cavilaciones filosóficas que nos llevan desde un ámbito jacarandoso, en el que el cuerpo es fuente de placer, hasta otro luctuoso, en el que el cuerpo se nos presenta en 
toda su corruptibilidad, como fuente de dolor, desesperanza y muerte" (1999: 1628).

Por otro lado, también el cuerpo como objeto de deseo — principalmente, deseo homoerótico-, se encuentra como una constante en la escritura sarduyana que permite enlazar sus novelas $-\mathrm{y}$ toda su obra poética y ensayística - en una preocupación que es, además, un enclave fundamental en su vida.

Las relaciones entre personas del mismo sexo no siempre fueron consideradas o "evaluadas" de la misma manera. Esto se ve claramente reflejado en los distintos términos que se han acuñado con el fin de denominarlas. Así por ejemplo, para el mundo antiguo, pederasta es la forma que implicaba a la vez a la institución pedagógica, militar, política y sexual, y sodomita, en cambio, el término elegido en función del texto bíblico que refiere la destrucción de las ciudades de Sodoma y Gomorra, atribuida por el mundo europeo a la necesidad divina de castigarlas por las prácticas sexuales entre hombres (Melo 2005: 15$)^{98}$.

La palabra homosexualidad, por su parte, aunque había sido usada en oportunidades anteriores, tuvo su nacimiento institucional más preciso en 1887 con la aparición de la segunda edición de la enciclopedia de desviaciones sexuales Psychopathia sexualis de Krafft-Ebing (17) que no fue más que una de las manifestaciones de la implementación de las “mecánicas de poder", descriptas por Foucault, que implicaron la

\footnotetext{
${ }^{98}$ Adrián Melo desarrolla con profusión las distintas formas de entender y representar las relaciones entre personas del mismo sexo en la literatura en El amor de los muchachos. homosexualidad y literatura. Buenos Aires: Ediciones Lea, 2005.
} 
patologización médica y la penalización por parte del Estado ${ }^{99}$. Este proceso recién empezaría a revertirse, al menos en lo que a las clasificaciones médicas se refiere, en 1973, cuando la American Psychiatric Association suprimió la homosexualidad de su lista de patologías mentales, aunque, es necesario advertir, ya algunas voces no menores como la de Freud se habían levantado en contra de esta patologización (Castañeda 2000: 32).

Los acontecimientos históricos, sociales y culturales de los años sesenta a los que he hecho referencia marcaron también en este aspecto un hito que tuvo como una de sus manifestaciones más notorias la reutilización de un término antiguo, "gay", con nuevos objetivos. De origen francés, "gai" calificaba a las cosas agradables, pero ya en el inglés del siglo XVI se refería a la disipación y los placeres inmorales y en el XIX incluía a la prostitución femenina (Melo 19) ${ }^{100}$. Si bien es cierto que siempre es difícil datar con exactitud la primera utilización de un término, se considera que fueron los hechos sucedidos en el bar neoyorquino "Stonewall Inn" la piedra fundamental para esta revisión en torno de la cuestión homoerótica ${ }^{101}$. En

\footnotetext{
${ }^{99}$ Este surgimiento médico-legal patologizante y discriminatorio es, según David Foster, la causa por la que la palabra "homosexual" está desacreditada en inglés, aunque en español continúa siendo considerablemente neutral (2008:924). En el artículo referido, Foster repasa la producción teórica sobre los temas gay en América Latina desde 1980 elaborando breves reseñas constituyen una herramienta útil para conocer los principales aportes vigentes.

${ }^{100}$ Para otras referencias del empleo de la palabra gay, ver Llamas, Ricardo. Teoría torcida. Prejuicios y discursos en torno a "la homosexualidad". Madrid: Siglo XXI de España Editores, 1998.

101 La redada del "Stonewall Inn" no fue la primera ni mucho menos la única que se produjo en los Estados Unidos de las décadas del cincuenta y sesenta. En tal sentido, cabe recordar que el llamado "macarthismo", dispositivo de persecución empleado contra los comunistas, anarquistas y todas aquellas personas consideradas como "antiestadounidenses" - entre los que también estaba incluidos los homosexuales- que alude al senador Joseph McCarthy, principal encargado de llevar adelante este procedimiento, las tuvo como uno de sus métodos habituales de represión. La supuesta "esencia homosexual" se caracterizaba durante este período como falta de carácter y de estabilidad emocional por lo que la propensión a la degradación moral de la administración podía venir como consecuencia de la mala influencia de los sujetos que eran así descriptos. Para el
} 
junio de 1969 una redada policial francamente homofóbica puso en pie de guerra a las comunidades gays y lésbicas, marginadas por su elección sexual, por lo que comenzaron a formar parte de la rebelión esperada y provocada por los "aires de los tiempos". Pero también, contribuyeron en gran medida a sostener esta disposición a la revuelta y, en este caso preciso, a darle una envergadura que se vería reflejada en la construcción de un amplio campo de trabajo intelectual y político que no deja de reflexionar aún hoy acerca de la problemática, por paradójica —en tanto implica necesariamente recortar, clasificar, encauzar, y por qué no, disciplinar-, cuestión de nominar de algún modo este campo de estudios ${ }^{102}$. Claro que, parece ocioso decirlo, la complejidad del debate no está dada por la designación de un área disciplinar sino porque esto implica, en primer lugar, un proceso político de construcción de subjetividades en el que algunas

macarthismo, la presencia de gays y lesbianas en las instancias de gobiernos era asociada, entonces, con una estrategia del comunismo destinada a "infectar" a la sociedad en tanto uno era una amenaza para la familia nuclear y el otro para el Estado nuclear: "Familia (patriarcal) y nación se confunden igual que homosexual (depredador) y comunista (Llamas 1998: 108; 1999: 103).

Curiosa y paradójicamente, estos son los mismos argumentos y sustentos ideológicos utilizados por el comunismo de Cuba o la Unión Soviética para implementar las mismas estrategias de exclusión y reclusión para los "indeseables" de toda índole.

El 28 de junio ha sido instituido como "del orgullo gay y lésbico" en homenaje a los acontecimientos de Stonewall.

José Amícola considera que la adaptación hecha por Manuel Puig para el cine de la novela El lugar sin límites de José Donoso constituye un "documento único sobre la representación de las diferencias sexuales en Latinoamérica en el momento alrededor del "motín de Stonewall”". Para un análisis más detallado, ver Amícola, José. (2006). "Hell Has No Limits: de José Donoso a Manuel Puig". En Ingenschay, Dieter. Desde aceras opuestas. Literatura/ cultura gay y lesbiana en Latinoamérica. Vervuert: Iberoamericana.

${ }^{102}$ El número 225 de la Revista Iberoamericana, publicada por el Instituto Internacional de Literatura Iberoamericana en octubre-diciembre de 2008, es un ejemplo reciente y notorio de la preocupación de los investigadores por el problema de la designación de los estudios en cuestión. Tanto es así que no sólo el volumen llevó el nombre amplio de "estudios lésbico-gays y queer latinoamericanos" [las cursivas son mías] sino que, además, incluye dos artículos cuya reflexión principal ronda en la conveniencia o no de utilizar el término queer para los estudios latinoamericanos - "Hacia un verbo queer" de Amy Kaminsky y "Retos, riesgos, pautas y promesas de la teoría queer" de Brad Epps- y un tercero - "El estudio de los temas gay en América Latina" de David Foster- que si bien no aborda la cuestión del nombre como problema central lo toma en el primero de los apartados "Definiciones en discusión". 
personas se ven compelidas a ocultar un aspecto de sí mismas bajo la amenaza de la estigmatización social que produce exclusión —negación, exilio, abyección...

En este sentido, una de las vetas por las que discurre el debate es en torno a la pregunta acerca de qué es y cuáles son las causas de la homosexualidad, a partir de las cuales surgieron dos concepciones fundamentales, una esencialista y otra construccionista, que constituyen dos aproximaciones epistemológicas contradictorias y conflictivas sustentadas en principios de determinismo o historicidad, respectivamente.

Según la tesis esencialista, la homosexualidad es un rasgo biológico, congénito y natural que aparece en todas las épocas y en todas las sociedades. No constituye una elección sino una condición con la cual se nace, una enfermedad por lo que, el individuo, en tanto no es responsable de su orientación, es tomado como un enfermo que merece tratamiento médico y como víctima del destino, comprensión y paciencia ${ }^{103}$. En algunos casos, la homosexualidad entendida como una esencia ha sido asumida por grupos que pretendían luchar a favor de los derechos de las personas gays. El argumento apunta a demostrar que si la homosexualidad es un hecho biológico, natural, no es entonces ni una enfermedad ni una degeneración sino que representa una variación sexual, una parte del orden natural, por lo que la población homosexual es una minoría como cualquiera de las otras con los mismos derechos civiles que la mayoría (Castañeda 46-8). Claro que

${ }^{103}$ La homosexualidad entendida como un rasgo biológico da lugar a una dimensión genética que, aunque ha sido abordada por numerosos estudios, generó múltiples controversias no sólo por la precariedad de las conclusiones sino, fundamentalmente, porque esta búsqueda de rasgos genéticos mucho recuerda a las teorías del italiano Cesare Lombroso (1836-1909) por medio de las cuales se pretendía explicar la delincuencia estudiando las características físicas como propias de los individuos en cuestión. 
este abordaje, aún cuando se haga desde las buenas intenciones de despenalizar y despatologizar la homosexualidad, adolece de cierto autoritarismo epistemológico en tanto habilita el análisis de múltiples y complejas realidades bajo un solo prisma científico.

Por su parte, la tesis construccionista - con Foucault como uno de sus principales promotores- postula el carácter histórico de la homosexualidad por lo que ésta no sería el producto de la emergencia de unas propiedades comunes a otras personas distantes en el tiempo y el espacio sino que, por el contrario, sus particularidades dependen de complejos sistemas de relaciones y procesos institucionales, culturales, económicos, políticos y sociales localizados geográfica y temporalmente. En tal sentido, es anacrónicamente incorrecto y fuera de lugar establecer generalizaciones entre distintas comunidades o hablar de homosexualidad más allá de determinada fecha histórica y de la cultura occidental, básicamente eurocéntrica. Según esta tesis, la homosexualidad no viene dada por factores biológicos que atañen exclusivamente a la sexualidad sino que se construye e implica otros aspectos de la vida de la persona. Es así que se puede hablar de una "identidad gay" que constituye no sólo una elección erótica sino también una manera de vivir y de pensar, determinados gustos y modas, determinadas posturas políticas, una "cultura gay" en torno de la cual se reúne una comunidad. En este sentido, la homosexualidad es una construcción que no adopta una forma única sino que cambia en función de la sociedad y de la propia historia personal del individuo (Castañeda 55). Las cosas así entendidas, permiten, en mi opinión, un gesto político de envergadura ya que "desnaturalizada" y "desencializada" la 
"homosexualidad" también se desnaturaliza la "heterosexualidad" por lo que se pone en evidencia — proceso que inició el mismo Foucault pero en sentido inverso- el carácter construido del régimen de la sexualidad por las relaciones de poder. En el mismo sentido, Llamas afirma que "el establecimiento de la categoría "homosexual" implica también el de su categoría antitética, "heterosexual", y lo que una o uno "es" supone indirectamente lo que las demás o los demás "no pueden ser" (26).

Sin embargo, ambas posturas tienen repercusiones liberadoras pero también son susceptibles de constituir el argumento de estrategias represoras. Así, si por un lado la hipótesis de construcción incide en la “institucionalización de regímenes de control, en la arbitrariedad de las diferencias, en el carácter "polimorfo" de los deseos, en la incoherencia de las sanciones y en el carácter innecesario de las formas de represión”, por otro lado la censura y la discriminación suponen estos enunciados construccionistas (27-8). Las categorías esencialistas, por su parte, implican el establecimiento de bases de resistencia comunitarias, el carácter inmodificable del deseo y la necesidad de implantar medidas de protección de derechos y libertades pero también sirven de fundamento a la reclusión y el exterminio (28).

La propuesta, entonces, implica la construcción de líneas de análisis que permitan escapar a esta lógica dicotómica excluyente que no da cuenta de la complejidad del tema sino que lo reduce a extremos irreconciliables en los que, necesariamente, no se contemplan ciertas franjas de ambigüedad que enriquecerían la discusión. Según Butler, de lo que se trata es de cambiar los términos del debate con el fin de dejar la oposición entre 
constructivismo y esencialismo para "pasar a la cuestión más compleja de cómo las restricciones "profundamente arraigadas" o constitutivas pueden plantearse en términos de límites simbólicos a su indocilidad y disconformidad" (2002:144). Dicho de otra manera, se trata de un proceso que articula elementos de orden biológico o psicológico con problemáticas históricas, económicas, políticas o culturales por lo que es la interacción de ambas perspectivas que permite trascender las formas "puras" lo que otorga relevancia a los estudios de las realidades gays y lésbicas (Llamas 29-30).

En cualquier caso, es importante notar que, más que nunca, los distintos abordajes en torno a las relaciones homoeróticas constituyen puntos de anclajes políticos en un debate que no sólo tiene plena vigencia sino que se está construyendo diariamente, en el ámbito académico, en la militancia o la cotidianeidad de la vida. Pero más importante que esto es que, en la actualidad, a diferencia de otros momentos históricos, los que toman la palabra en esta controversia y construyen un discurso autorreferencial con el objetivo de autodefinirse, para que no los definan otros, y de esa manera, elegir el lugar que prefieren ocupar, son los protagonistas de esta historia de exclusiones que se fundamenta en hacer de la elección erótica un campo de batalla en el que se juegan cuestiones de saber, disciplinamiento y poder por lo que es posible afirmar, siguiendo a Llamas, que la politización de las realidades lésbicas y gays es un corolario de la politización de estas instancias que les son ajenas (1998:10). Dicho de otro modo, constituyen una respuesta al régimen de sexualidad que impone criterios sobre los que se interpretan las relaciones afectivas, el deseo, las prácticas corporales placenteras y todos los órdenes de la vida sobre los 
cuales tiene implicancias en base al modelo de una heterosexualidad pretendidamente coherente (11).

En tal sentido, los acontecimientos de Stonewall no sólo fueron el puntapie inicial para la incorporación de los términos gay y lésbico sino que, en estrecha relación con esto, establecieron las bases para un discurso en primera persona y reivindicativo que permitió la emergencia de estrategias organizativas de articulación y desarrollo de movimientos de protesta $^{104}$. Una de las razones fundamentales que dio lugar a la reutilización de estos conceptos es, precisamente, que ignoran las connotaciones médicopsiquiátricas de la palabra "homosexual" en tanto no son construcciones discursivas que se definen en relación con otra instancia, lo "heterosexual", puesta en el lugar de lo "normal" o "sano", por lo que gay y lésbico constituyen, entonces, nociones que connotan la construcción de una identidad en lucha basada en el orgullo de la diferencia (Castañeda 30). Ricardo Llamas justifica su decisión de hablar de "realidades gays y lésbicas" en tanto lo entiende como un concepto que "pretende distanciarse de cualquier tipo de fenomenología concreta, pretende no dar por supuesta ninguna regularidad, ni en las manifestaciones ni en las implicaciones" (1998: 40).

Judith Butler, por su parte, introduce el término queer como categoría política en tanto entiende que "emerge como una interpelación que plantea la cuestión del lugar que ocupan la fuerza y la oposición, la estabilidad y la variabilidad, dentro de la performatividad" [Itálicas en el

${ }^{104}$ Para un análisis de las distintas organizaciones surgidas en defensa de los derechos de lesbianas y gays y las estrategias políticas utilizadas por cada una de ellas, ver el texto referido de Ricardo Llamas. 
original] (2002: 318) ya que es un término que en sus inicios se usó para avergonzar al sujeto nombrado y fue la invocación repetida que lo vinculó con la patologización y el insulto por lo que provocó, a lo largo del tiempo, un vínculo social entre las sociedades homofóbicas. En esta historia — genealogía nietzcheana- reside, precisamente, la fuerza política del término, aunque también uno de los impedimentos de su generalización en otras lenguas como, por ejemplo, el español ${ }^{105}$. Lo importante en este sentido es, según Butler, que queer continúe siendo un concepto nunca plenamente poseído, sino que siempre se tuerza, se desvíe de un uso anterior y, de ese modo, se oriente hacia propósitos políticos (320) aún cuando represente una forma de afiliación necesaria (323). Visto de este modo, la palabra queer le permite a Butler desarticular el sistema binario de los sexos —el cual sigue presente en las nociones gay y lésbico- y romper con la lógica de dominio que separa lo normal de lo abyecto (Femenías 2000: 218).

\footnotetext{
${ }^{105}$ En un artículo mencionado, Brad Epps afirma que lo verdaderamente inquietante de usar el término queer fuera del contexto angloparlante es "la falta de memoria interpersonal, de familiaridad, de calle" que a la vez delata y enmascara (2008: 898). A lo que agrega: "En un contexto no angloparlante [...] el término "queer" no es ni callejero ni coloquial sino foráneo, extraño y nuevo incluso, y tiende a usarse de manera casi exclusivamente académica y/o teórica: es, en breve, una palabra cuya fuerza reivindicativa [...] precede toda memoria de su carga injuriosa (una memoria, por otra parte, ligada a textos y contextos en inglés)" [Itálicas en el original] (899).

Por su parte, Ricardo Llamas refiere que otra de las críticas que se le hacen al término queer es la de constituir, por su imprecisión, una etiqueta que induce a estrategias de desidentificación que, si por un lado lo hacen susceptible de apropiación, por el otro constituye un paraguas de posiciones de resistencia múltiples e inestable que no supone igual legitimidad para todas (1998: 380).
} 


\section{III.4. Colibrí: simulación e intersticios}

\section{4.1. La simulación}

La función del modelo es contener, limitar, lo que sin su borde sería furia del pincel desaforada y proliferante, pintura de acción sin cauce, brochazos informes, chorreaduras, gestos.

Severo Sarduy, La simulación

Roberto González Echevarría, en su ya canónico La ruta de Severo Sarduy (1987), afirma que en Colibrí (1984) hay un "retorno a formas más convencionales y un alejamiento del campo de la pura experimentación" que se debería a "la dispersión del grupo Tel Quel y a [...] cierta retirada en el plano de la teoría" causadas, de alguna manera, por las muertes de Roland Barthes, Michel Foucault y Jacques Lacan, pero también, por el cansancio que estos autores fueron sintiendo con respecto a la teoría y que poco a poco derivó hacia lo autobiográfico y lo estético (212-14). Entiendo que esta consideración se sustenta, en alguna medida, en un análisis que pone en relación la "sencillez" de la trama narrativa de esta novela frente a la "sofisticación" formal de obras como Cobra.

En su análisis de Colibrí, el crítico concluye que la novela es el producto del viaje que Sarduy realiza por América del Sur a principios de los ochenta y gracias al cual recupera lo que denomina la "temática americana más tradicional, cuyo centro es la naturaleza y cuyo paisaje es obsesivamente la selva" (212-13). Este argumento le permite analizar a 
Colibrí como inversión de la novela de la selva -teniendo como exponente más destacado en Cuba Los pasos perdidos (1953) - de manera que Sarduy retomaría aquí la idea de síntesis de lo americano que Alejo Carpentier ensaya en su obra reconociendo, de este modo, a su compatriota como maestro. Otros autores como Malva Filer (1998) amplían esta idea afirmando que Sarduy se apropia de una tradición que incluye también a $L a$ vorágine (1924) de José Eustasio Rivera o Doña Bárbara (1929) de Rómulo Gallegos, tanto como algunos aspectos de la narrativa de Gabriel García Márquez y Mario Vargas Llosa ${ }^{106}$.

Sin embargo, aunque acuerdo en muchos sentidos con el trabajo de González Echevarría, me permito discrepar, en este caso, en tanto considero que, si bien es cierto que las tramas han sido narradas de forma más simples también es verdad que perviven y se renuevan ciertos procedimientos discursivos que no sólo mantienen una vinculación estrecha con sus obras anteriores sino que tienen la clara función de no establecer "formas convencionales".

En tal sentido, me interesa retomar una idea esbozada por Lidia Santos, en su texto Kitsch Tropical. Los medios en la literatura y el arte en América Latina (2001) que considero productiva para avanzar con el análisis de la novela. En este trabajo, Santos considera la ornamentación de la obra sarduyana -más específicamente en Cobra y Colibrí- como recreación de los cabarets de travestis donde transcurren esas obras. Introduciendo la noción de camp, tal como la desarrolló Susan Sontag en su ensayo "Notas sobre lo camp" de 1964, el abordaje le permite concluir —en

\footnotetext{
${ }^{106}$ Considero que una vinculación obvia es la que se puede establecer entre "la Casona" sarduyana y la "casa verde" de Vargas Llosa.
} 
un punto concordante con González Echevarría- que, en Colibrí "hay un cierto abandono de las posiciones dogmáticas del post-estructuralismo" que constituye, además, "un comentario risueño sobre la cultura literaria hispanoamericana” (169). Esta noción pensada en relación con la pervivencia de algunos elementos de la estética neobarroca sarduyana es lo que, en mi opinión, permite trascender la lectura del regreso a la convencionalidad de las formas para pensar en qué sentido este puede ser la simulación de un regreso.

Fiel al espíritu que habría de envolverla a través de los años hasta el presente, una de las primeras apariciones públicas de la palabra camp se produjo en 1918 de manera abiertamente conflictiva en tanto estuvo vinculada al accionar censurador de la policía neoyorquina en una presentación teatral de la actriz Mae West (Amícola 2007: 283). Pasarían desde entonces varias decenas de años hasta que en 1964 Susan Sontag le otorgara un lugar en su trabajo teórico a partir del cual la noción de camp comenzaría a tener su propia vida como herramienta de análisis.

Sontag atribuye el comienzo del camp a finales del siglo XVII y principios del XVIII cuando se produce una importante inclinación del arte hacia el artificio, la superficie, la simetría, lo pintoresco y lo emocionante. Lo entiende como una sensibilidad moderna que constituye una cierta manera de mirar el mundo como fenómeno estético pero que no se establece en términos de belleza sino en función del grado de artificio y estilización que, aunque se entiende que existe una mirada camp con el poder de transformar una experiencia, bien puede ser una cualidad perceptible de los objetos y del comportamiento de las personas (2005: 357). El gusto por el 
camp, según Sontag, tiene preferencia por determinadas manifestaciones artísticas relacionadas con la decoración visual pues el arte camp enfatiza la textura, la superficie sensual y el estilo en detrimento del contenido. Esta acentuación del estilo implica, para Sontag, una sensibilidad no comprometida y despolitizada, características con las que, acertadamente en mi opinión, no acuerda José Amícola y que atribuye a una influencia de los intelectuales marxistas de su momento quienes propugnaban aun la idea sartreana del arte comprometido.

Por otra parte, este énfasis también está íntimamente relacionado con otra característica que da Sontag que es el camp como expresión de la metáfora de la vida como teatro con lo que introduce otras problemáticas fundamentales, estrechamente vinculadas entre sí y con un fuerte anclaje político, en mi opinión, que son la imitación y el travestismo: "la forma más refinada del atractivo sexual $[\ldots]$ consiste en ir contra el propio sexo. Lo más hermoso de los hombres viriles es algo femenino; lo más hermoso en las mujeres femeninas es algo masculino" (360). Ligado a esto aparece la noción del andrógino que constituye un elemento de significatividad singular en esta estética y que confirma un posicionamiento particular dentro del campo cultural en tanto promueve una postura que rechaza los estados extremos tanto como las armonías. En tal sentido, si la primera sensibilidad, la de la alta cultura, es básicamente moralista y la segunda, representada por el arte contemporáneo de vanguardia, obtiene su fuerza de una tensión entre lo moral y la pasión estética, lo camp —exclusivamente estético- niega el eje bueno/ malo y sólo se limita a ofrecer normas, diferentes y complementarias, para el arte y la vida. 
La gran propuesta de lo camp es destronar lo serio, ser lúdico, presentar una visión cómica del mundo, no amarga ni polémica, sino distanciada por lo que, en tanto el distanciamiento es prerrogativa de una elite y el dandy el sustituto decimonónico de la aristocracia, la pregunta que se plantea Sontag es quien puede ser el $d a n d y$ en la época de la cultura de masas. Vinculando la sensibilidad camp al gusto snob, Sontag responde entonces que son los "homosexuales", como "clase improvisada y autoelegida" (373), quienes se constituyen en aristócratas del gusto por decisión propia ya que lo camp es un "disolvente de la moralidad" "peculiarmente apto como justificación y proyección de un determinado aspecto de la situación de los homosexuales" (374).

En tal sentido, Amícola, siguiendo a Andrew Ross, afirma que fue durante los años sesenta cuando el camp tuvo su mayor ímpetu ya que la profusión con la que se empezaron a ver las películas de la época de oro del cine de Hollywood en la televisión norteamericana produjo entre los televidentes, entre los que se contaban grupos gays en búsqueda de cierta visibilidad social, no sólo una "hollywoodmanía" y un gusto por lo retro sino también, y como consecuencia de esto, la formación de una identidad que, en alguna medida, tenía una profunda vinculación de identificación con las protagonistas (2008: 286). Visto de este modo, el camp se perfila como una reacción contra la homofobia en tanto constituye la puesta en práctica de ciertas estrategias que tienen la finalidad de darle visibilidad y dignidad a las sexualidades disidentes (287).

Colibrí es el relato del viaje -quizás convendría más decir "los viajes"- que un personaje masculino -Colibrí-, a todas luces 
latinoamericano, realiza desde y hacia la selva y a partir del cual va cambiando y construyendo su personalidad en relación con el entorno social y natural que va dejando sus huellas inscriptas en él hasta transformarlo en alguien completamente distinto al del comienzo. Llegó a la Casona, pródiga en "mimos o maltratos" — según el gusto del requiriente-, un día cualquiera, en una barcaza de carbón, como tantos otros adolescentes provenientes de algún pueblo del estuario. Rubio — “pero cuando digo rubio tienes que visualizar un pelo inmenso y engrifado, resplandeciente, albino más que rubio" (Sarduy 1999 [1984]: 693)—, casi virginal, despertó el deseo implacable de la Regente y con él, la persecución que lo empujó por un itinerario tan inesperado como insolente y que terminó con el regreso a la Casona, dispuesto a ocupar el lugar que fuera de la Regente. Pero lo significativo es que en este relato, en apariencias tan similar a los modelos épicos de la narrativa de la selva hispanoamericana, no hay elemento alguno que se construya siguiendo las características de este tipo de obras ${ }^{107}$. Así, por ejemplo, Colibrí, en franca contraposición con el modelo masculino, monológico, destinado a instituir una cultura y una identidad fijas y determinadas que implica la figura heroica, entabla relaciones homoeróticas,

\footnotetext{
${ }^{107}$ La novela de la selva latinoamericana tiene su origen y escenario privilegiados en la explotación cauchera en las cuencas del Amazonas y el Orinoco durante los primeros años del siglo XX. Sin embargo, las dos obras más canonizadas por la tradición literaria latinoamericana - La vorágine (1924 y Canaima (1935) - fueron escritas cuando la demanda internacional del látex había bajado y sin que sus autores, José Eustasio Rivera y Rómulo Gallegos, respectivamente, hubieran tenido un contacto real con el lugar y la situación de referencia por lo cual se basaron principalmente en las fuentes textuales provistas por las investigaciones de cronistas europeos y latinoamericanos. En tal caso, si es posible afirmar que la explotación cauchera construye la selva como tema para la literatura no es apropiado decir, entonces, que estas novelas le otorgaron un lugar en el imaginario de la nación sino que contribuyeron a reforzar ese imaginario que existía aún antes de su publicación (Rueda 2003). Este hecho, además de suscitar críticas que en su momento contribuyeron a restarles valor documental y de denuncia a las obras, da lugar a reapropiaciones como las de Sarduy en las que se intenta poner en evidencia su carácter de construcción y simulación discursivas.
} 
es ambiguo en su forma de actuar, puesto en discusión por el narrador, plagado de contradicciones y dispersiones y, en su "camino de aprendizaje", no deviene líder sino dictador, autoritario.

Por su parte, la naturaleza, no constituye el mito de la virginidad y de ésta en relación con la recuperación de la identidad sino que, por el contrario, es un espacio que en todo momento se revela contaminado, inhóspito y agresivo para con quienes se atreven a adentrarse allí. En este sentido, considero que el relato sarduyano sí se asemeja a la novela de la selva en tanto representa la naturaleza no en su esplendor sino en sus hostilidades. Según Rueda, la selva se presenta personificada como cuerpo femenino que espera la penetración del hombre pero a la vez la rehúye ya que el papel que le ha sido asignado en su versión de paraíso es el de la madre virgen que rechaza el contacto sexual con sus hijos. Sin embargo, los colonizadores de la Amazonía cometieron la imprudencia de querer penetrarla y poseerla y, por lo mismo, de intentar cometer incesto. Esta intromisión de los trabajadores del caucho rompió el orden natural y convirtió a la selva en un infierno, en enemiga del progreso, en territorio/cuerpo hostil (2003: 38-9). Es de notar, entonces que, en Colibrí lo que se rompe no es la armonía del cuerpo femenino virgen sino, por el contrario, la estructura de conformación genérica de ese cuerpo que establece las diferencias insalvables entre los sexos basándose en una conformación biológica y sexual a todas luces insuficiente para establecer dichos parámetros. Claro está que, con esto, también se rompen las relaciones heterosexuales que constituyen la normatividad occidental moderna. 
Pero además, y esto quizá sea más relevante aún, la naturaleza es desenmascarada en su carácter de invención, de ficcionalidad, ya que los paisajes, en realidad, no son más que bambalinas y decoraciones que los distintos enunciatarios van distribuyendo a su antojo, según como quieran variar la versión de la historia. De este modo, el relato sarduyano funciona como un dispositivo político-discursivo poniendo en evidencia el proceso de ficcionalización que opera en la larga tradición de los relatos y crónicas de viajes que conforman la literatura latinoamericana y que tuvo como una de sus operaciones fundamentales la construcción de una naturaleza virgen, abundante, extraordinaria, como un espectáculo sobrecogedor a partir del cual se inventó y reinventó América. Cristóbal Colón, Américo Vespucio, Alexander von Humboldt son algunos de los nombres directamente relacionados con esta tradición ${ }^{108}$.

Sin embargo, el tópico de la naturaleza los excedió tanto como a los relatos de viajes y constituyó un eje vertebrador que atraviesa las preocupaciones, tan disímiles como los sujetos que las expresan, del Inca Garcilaso de la Vega, José Martí, Andrés Bello, Sarmiento o entre los más recientes Rómulo Gallegos, Alejo Carpentier y el mismo Gabriel García Márquez, entre muchos otros. Esto implica entonces, un mecanismo que se repite en cada caso y que consiste en que el grupo de letrados de cada momento se atribuye la función de construir, imaginar esta naturaleza,

\footnotetext{
${ }^{108}$ Para un análisis exhaustivo de los relatos de viajes en la literatura latinoamericana ver Colombi, Beatriz. (2004). Viaje intelectual. Migraciones y desplazamientos en América Latina (1880-1915). Rosario: Beatriz Viterbo Editora, y "El viaje y su relato" (2006). Latinoamérica. Revista de Estudios Latinoamericanos. 043, 11-35.

Por su parte, la Revista de Crítica Literaria Latinoamericana dedicó, en su número del segundo semestre de 2004, un dossier a las relaciones de viajes en el que participan autores como Elena Altuna, Rodolfo Franconi, María Laura de Arriba, Lydia Fossa, Rolena Adorno, Silvia Tieffemberg, por nombrar sólo algunas de las personas que hicieron sus aportes a este trabajo.
} 
otorgarle un sentido simbólico que responda al proyecto político vigente, sea éste la colonización, las independencias o la revolución. Graciela Montaldo afirma al respecto:

La naturaleza y los paisajes en la literatura latinoamericana son desde los comienzos aspectos altamente construidos, o sea, altamente formalizados por los letrados que vieron en su representación formas de intervenir en la vida pública a través de versiones sobre lo real histórico (1995: 106).

En resumidas cuentas, teatralización de la vida, humor, travestismo son en Colibrí manifestaciones de una estética que pone en juego dos vertientes culturales antagónicas —una de "elite" y otra de "masas", una "alta" y otra de "mal gusto", lo barroco y lo camp - con la finalidad de "destronar lo serio" que, en este caso, es lo mismo que decir, poner en jaque la tradición literaria hispanoamericana sustentada en cierta construcción ficcional de sí misma y de la realidad en la que pretende sostener sus bases.

\section{4.2. El intersticio}

Para saber qué simula, habrá que ir, pues hasta ese espacio en el que el saber no está en función binaria, ni surge en el intersticio, el magnetismo o la antagonía de los pares opuestos $[\ldots]$

Severo Sarduy, La simulación

Para saber qué simula, entonces, propongo rehacer esta lectura teniendo en cuenta la instancia de la enunciación que, en el caso de Colibrí, nos permite analizar el problema de los géneros que rondará tanto en vacilaciones entre tipos de géneros discursivos y literarios como en 
cuestiones de género sexual. Esta problemática se encuentra anticipada en cuatro breves textos iniciales: dos de ellos son dedicatorias, a su padre, porque le regaló un colibrí, y a Roberto González Echevarría, porque escribió un libro sobre sus libros. El tercer texto constituye una aclaración de principios poéticos:

Ésta es una obra de ficción. La razón por la cual algunos de sus personajes podrán parecerse a personas de la vida real, es la misma por la cual algunas personas de la vida real parecen personajes de novela. Nadie, por lo tanto, tiene derecho a sentirse incluido en este libro. Nadie, tampoco, a sentirse excluido (Sarduy 1999 [1984]: 692)

Finalmente, el último texto es una cita de José Lezama Lima cuya única justificación aparente está en la referencia al colibrí y que, en principio, carece de exaltación y ceremonia.

Cada uno de estos textos adelanta uno de los temas de los que se va a hacer cargo la novela: la homosexualidad y la relación del propio Sarduy con su padre y con la escritura en la primera dedicatoria, la crítica, la literatura y los linajes en los últimos. En resumidas cuentas, ya desde los epígrafes Sarduy despliega su proyecto de escritura pero lo hace desde la ambigüedad y la contradicción ya que los que son reconocimientos se convierten, en el discurrir de la novela, en recriminaciones o puestas en duda - por ejemplo, en el caso del padre quien le discute su actividad literaria pero también lo increpa por su elección homoerótica- o, en la cita lezamiana que conserva un tono de poco entusiasmo pero se transforma, gracias a otra alusión que aparecerá más adelante, en un homenaje a su colega y compatriota. Por último, en el fragmento citado, la ambivalencia se manifiesta claramente pero para dejar en evidencia que no existen las 
certezas, ni siquiera, las que nos permitirían marcar los límites entre la realidad y la ficción, entre la vida y la obra, entre las personas y los personajes... pero tampoco, o mucho menos aún, entre los incluidos y los excluidos.

De esta manera, Sarduy habla de identidad y literaturidad, pero también lo hace desde las estrategias que utiliza en la voz enunciativa y que constituyen modos a través de los cuales incluye rasgos de diferentes géneros dentro de la novela. Así, nos encontramos con que el empleo de la tercera persona -en la que, a fin de crear el efecto de ficcionalidad, oculta el proceso de la enunciación- es, en Colibrí, disperso y hasta, podría decir, poco frecuente, ya que constantemente se interrumpe con otros procedimientos que se le contraponen porque tienen como finalidad denunciar los mecanismos de enunciación que operan en el texto y hacer de éstos la puesta en escena del proceso de escritura: un espectáculo dentro del espectáculo.

Algunos ejemplos, en este sentido, son los comentarios en los que el narrador reflexiona sobre su práctica enunciativa y lo hace dirigiéndose a una segunda persona, singular o plural, a partir de la cual se crea una estructura conversacional que acerca el relato al ámbito de la oralidad: "Era, por supuesto, rubio. Pero cuando digo rubio tienes que visualizar un pelo inmenso y engrifado" (693). En otro caso, la narración asume el tono de grandilocuencia y exaltación propios de una presentación en público: "Se oye El caballero de la Rosa, que abre las páginas sonoras de la Novela del Aire, para hacer vivir a ustedes la ilusión y el romance de un nuevo capítulo" [Itálicas en el original] (746). Pero también hay momentos en los 
que el enunciador parece instalarse nuevamente en la lengua escrita y desde allí les hace guiños de complicidad a los lectores para burlarse de Colibrí:

¿Quién iba a ser? ¿Quién, dime, después de la Enana y sus acólitas fracasadas, sino su doble y anamorfosis? Claro está. Todo el mundo lo ve. Todo el mundo menos el alelado Colibrí [...].

Sí, adoradas y sagaces lectoras, es él [...] (733).

En otros momentos de la enunciación, la primera persona del singular cede su lugar a la primera de plural. El resultado es un nosotros ambiguo que no deja en claro quiénes son los incluidos ni en qué se los incluye. En el siguiente fragmento, por ejemplo, al empleo de la primera persona plural se le suma un punto de focalización particular por el cual la mirada parece haber sido dada desde una cámara televisiva. Así, nos alejamos, nuevamente, de la dimensión propia de la escritura, aunque la frase inmediatamente posterior nos devuelva de manera abrupta y $\sin$ vacilaciones a ella:

Dije que era voluminoso y liso, es verdad, pero ahora que lo vemos a nivel de la cintura y en primer plano [...] un baño de María adjetival se impone [...] - no tiene ni un pelo en el cuerpo - que engarza el regalo - bien menudo, entre paréntesis, en proporción -" (697).

Las notas a pie de página son parte de este cúmulo de procedimientos discursivos mediante los cuales Sarduy pone en discusión el problema de los géneros. En este caso, sin ser muchas, plantean cuestiones diversas. Desde una referencia explícita a ciertas prácticas de censura - el parametraje - ejercidas por el gobierno cubano post-revolucionario (698) hasta un texto explicativo a la manera de definición de diccionario (720). Entre estos extremos, una nota en la que Sarduy, con humor e ironía, hace referencia a la tesis de doctorado "sobre Las estructuras narrativas en la obra de Severo Sarduy" [Itálicas en el original] (722) constituye, sin más, 
una crítica - amable, por cierto - a la crítica literaria. En este mismo orden de cosas, en una nota que atribuye al editor, vuelve a romper el espacio de la ficcionalidad, sólo que esta vez lo hace para poner en escena el contexto de producción y circulación de la obra: “...y el distraído autor de estas páginas, tan atento a los valores formales y tan indiferente al relato, como si los lectores pagaran, y al precio que están los libros, para oír una musicanga más. Nota del editor" [Itálicas en el original] (726).

De este modo, la dispersión textual de esta obra no se contenta con la inversión de un modelo canonizado sino que desconoce todo modelo, rechaza la posibilidad de existencia de un original y admite como única autoridad posible el exceso y la dispersión de la copia y la simulación, de la abundancia y el travestimiento. En resumidas cuentas, rompe con la noción de canon y, por lo tanto, también con la de linaje. Sus reconocimientos se manifiestan en forma de ecos, de resonancias, de alusiones - a los lezamas enchilados, por ejemplo - y sus críticas, a la manera de la sub-versión.

Proliferación y travestimiento de género — tanto en la acepción textual como en la sexual- ... porque los personajes se transforman y multiplican pero también lo hacen las voces de este relato $\mathrm{y}$, en consecuencia, es el sujeto de la enunciación quien vuelve a adquirir características ambivalentes y contradictorias ${ }^{109}$. Un ejemplo de esto es que,

\footnotetext{
${ }^{109}$ La vinculación entre género textual y gender ha sido trabajada por José Amícola en La batalla de los géneros. Novela gótica versus novela de educación. Mediante un análisis comparativo que pone en relación "dos figuras de discursos sociales en potenciación mutua"(2003: 284), esto es los géneros literarios y los géneros sexuales, Amícola se propone indagar acerca de cómo las sociedades "encargan a sus representantes jurídicos y represivos que velen por ese respeto a la norma gramatical y social como un problema de gender, así como lo que ha sido denominado: "la policía del género"” (12).
} 
en uno de los últimos capítulos, es el padre del autor quien toma la palabra para recriminarlo por su afición a la escritura:

[...] voy a hablarte sonante y cantante. Ya tú eres un hombre y de los Sarduy, hasta ahora, no ha habido ningún pájaro. Y yo no quiero que nadie me señale en la calle. Así es que ahora mismo vas a quemar también esas cuatro mierdas. ¿Quién ha visto a un hombre jugando con fruticas de brilladera? (765).

En esta inclusión, el relato adopta una marca autobiográfica que le permite a Sarduy plantear aquellos temas de los que hablé: el de su elección sexual homoerótica y la escritura en relación con esto, por un lado, y el de la autoridad que lo sanciona tanto en su identificación personal como en su proyecto poético. Cabe traer a colación, entonces, las palabras de René Prieto para quien las cuatro mierdas son "los cuatro relatos -Gestos, De donde son los cantantes, Cobra y Maitreya- que identifican la homosexualidad del autor y que, dada su vocación transgresiva, simbolizan en todo sentido la ruptura con el padre y, al mismo tiempo, con la identidad normativa que su autoridad le impone como fardo y máscara [...]" (1991: $320)$.

En este orden de cosas, según Leonor y Justo Ulloa, la representación de las pulgas amaestradas y maquilladas por Colibrí, que se presenta en el capítulo "Guerra de escrituras", constituye una prolongación metonímica del simulacro entablado en la Casona que sirve para "intensificar un escenario pródigo en excesos, descomposición y muerte" y encubrir las preocupaciones sarduyanas en torno a la escritura, su vocación de escritor y el rol del lector (1994: 271). Hay, entonces, en estos cuatro actos, una reflexión en torno a la obra pasada - las "cuatro mierdas"- que, en mi opinión, adelanta un gesto de autor que Sarduy habrá de repetir en su 
novela póstuma. Para Ulloa y Ulloa, las "toutes prêtes", las "bonitas de un lado", las "anímicas" y el "Adán en pelotas" corresponden, respectivamente a Auxilio y Socorro de De donde son los cantantes, las transformaciones de Cobra, las viejas de Maitreya y Colibrí por lo que, concluyen: "En Colibrí, Sarduy parece pasar por un momento de autocrítica y valoración de su producción literaria enfocada desde el ángulo de la desautorización, la muerte y la descomposición” (272).

Y es éste, el de la descomposición del cuerpo, la enfermedad y la muerte, otro gesto que habremos de ver plenamente desarrollado en Pájaros de la playa y que, en Colibrí, constituye una de las problemáticas abordadas en forma velada, de alguna manera "oculta", bajo la dispersión y proliferación incesante del detalle y la fragmentación y que se propone desde la ambigüedad que plantea el título de la obra y nombre de su protagonista (Ulloa y Ulloa 1994).

"Colibrí" es un término que consigna una multiplicidad de sentidos pero, en este caso, podemos adjudicarle tres connotaciones fundamentales. Por un lado, remite al concepto de "pájaro" que, en la jerga latinoamericana y, más específicamente, cubana, es la forma en que son aludidos los homosexuales. En segundo lugar, apunta a las líneas de Nazca peruanas, en las que el colibrí es una de las figuras representadas, las cuales, según una de las interpretaciones posibles, corresponden a telares donde se hacían largos hilos con el fin de tejer mortajas que fueron utilizadas por los incas para envolver a sus muertos ${ }^{110}$. Por último, vinculado a la cita de Lezama

\footnotetext{
${ }^{110}$ En una entrevista realizada por Ulloa y Ulloa, Sarduy afirma, refiriéndose a Colibrí que, "El libro, en su materia, no tiene nada que ver con el gran colibrí del desierto de Nazca, pero sí en su funcionamiento". Siguiendo la tesis de Henri Stierlin y Albin Michel según la cual los trazados se utilizaban para tejer sudarios, Sarduy concluye que "No se trata de lo
} 
que sirve de epígrafe - "El colibrí, señor del terrón, / pasa del éxtasis a la muerte"-, el título intensifica la metáfora letal ya que si los sustantivos “terrón” y "éxtasis" remiten al juego textual y al descarrío homosexual de la Casona , "muerte" refiere a la metáfora que se construye a nivel de todo el texto, mediante la fragmentación y el detalle, y que alude - "oculta develando"- a la enfermedad que no se quiere nombrar, a la descomposición del cuerpo por la plaga, a la presencia subrepticia de la muerte (276-7). Como veremos en Pájaros, aquí también la gran elipsis se construye en torno a un mal, una plaga cuyo significante elidido es, no considero arriesgado suponer, el sida y su significado prefigurado, ineludible, impiadoso, la muerte. De este modo, según Dieter Ingenschay, Colibrí se transforma en la primera novela latinoamericana sobre el sida aun cuando la problemática sólo sea abordada tangencialmente (2006: 167)

Multiplicidad y dispersión de voces, proliferación y ambigüedad genérica. En resumidas cuentas, Sarduy construye en Colibrí una propuesta que excede la inversión de un orden. No pretende recuperar ni romper los cánones, ni establecer o discutir linajes, autoridades o formas sino, lo que es muy distinto, anularlos, escapar de sus lógicas de imposición, manifestarse como sujeto y artista marginal con respecto a este pensamiento totalizador, disidente con las narrativas creadoras de identidades y literaturas sintetizadoras. aterrizaran extra-terrestres-, ni a la de un calendario planetario único; no, lo extraño es lo marcado por el ritual de la cotidianeidad funeraria, por la muerte como código o gestualidad. En el más acá, en definitiva, está el más allá" [Itálicas en el original] (Ulloa y Ulloa 1984: 177). Así es, entonces, como Sarduy entiende que funciona Colibrí. 
"La escritura es el arte de descomponer un orden y componer un desorden” [Itálicas mías] (435) dice Sarduy en Cobra. Y éste, creo, es el más abarcador de todos los caminos recorridos. Porque la escritura también es el arte de simular: un personaje, una trama, un género, un orden, un itinerario. Pero la escritura no es capaz de copiar la Historia, un Sujeto, la Literatura, una totalidad. Por el contrario, presa de su propia incapacidad para crear una realidad, construye y se construye en los intersticios de una narrativa heterogénea, dispersa en voces, géneros y sentidos; una narrativa del desorden que se inscribe en el cuerpo, el género, el erotismo, la enfermedad y la muerte. 


\section{5. Literatura y sida: paradojas de una muerte anunciada}

Los tatuajes les sirven de calco para las escarificaciones. Quedan invisibles, protegidos por los arabescos ocres y ensangrentados de los ornamentos, pero contaminados de los pies a la cabeza por el mal. Ganan y desfallecen con la misma facilidad.

Severo Sarduy, Pájaros de la playa

Según la versión digital de la vigésima segunda edición del Diccionario de la lengua española la palabra "enfermedad" tiene tres acepciones, a saber: 1. alteración más o menos grave de la salud; 2. pasión dañosa o alteración en lo moral o espiritual; 3. anormalidad dañosa en el funcionamiento de una institución, colectividad, etc. Por su parte, el concepto que podría considerarse su antónimo, "salud", consigna los siguientes significados: 1. estado en el que el ser orgánico ejerce normalmente todas sus funciones; 2. condiciones físicas en que se encuentra un organismo en un momento determinado; 3 . libertad o bien público o particular de cada uno; 4. estado de gracia espiritual; 5. salvación; 6. inmunidad de quien se acoge a lo sagrado.

Sin pretender hacer un análisis minucioso de los términos en cuestión, es evidente que las acepciones mencionadas, además de presentar ciertas ambigüedades que hacen de la propia definición un constructo lábil, se ponen en evidencia como condensaciones de representaciones sociales que tienen sus anclajes lingüísticos en las formas de referirse a los estados de un sujeto. Se definen entonces la enfermedad y la salud en razón de "normalidad/ falta de normalidad", "moralidad/espiritualidad" que puede 
"padecer" tanto un individuo como una institución o toda una colectividad. De este modo, quedan instaurados por lo menos cuatro elementos de suma importancia en la construcción metafórica de cada una de las enfermedades en particular: la apelación a una norma para determinar quién está o no enfermo - y las arbitrariedades y autoritarismos que esto puede entrañar-, la apelación a una instancia moral y espiritual con una, en mi opinión, muy fuerte implicancia religiosa; la posibilidad de que sea un estado no sólo del individuo sino de un conjunto de personas amplio y abarcativo, inclusive, de una institución — la sociedad, la nación, el Estado- y, por último, la idea de que estar "enfermo" es un estado de pasividad, de "pasión" que somete al sujeto a los avatares y caprichos de, en la mayoría de los casos, la medicina clínica tradicional mientras que, veremos, estar "sano" es una responsabilidad individual o social que se relaciona directamente con las conductas de cuidado y prevención adoptadas por el sujeto.

Dicho de otra manera, en tanto acontecimiento negativo que amenaza con modificar la vida individual y social, la enfermedad es sometida a procesos de significación que no sólo se proponen indagar sobre sus causas sino construir una representación que sirva como soporte de la relación imaginaria entre el individuo y la sociedad por lo que es posible encontrar en cada período histórico una enfermedad que funciona como metáfora de los problemas de ese momento (Páez 1991: 103). Así, si en la antigüedad la lepra representó un hecho inevitable al que era imposible sustraerse, en la Edad Media la peste fue la materialización de un concepto trágico de la existencia sometido a un castigo colectivo por la ira de Dios y en el siglo XV el contagio venéreo de la sífilis supuso la crisis moral y 
espiritual provocada por el libertinaje de la población. Por su parte, en el siglo XIX la tuberculosis se encargó de marcar las miserias sociales propias del capitalismo, resultante de la crisis de los valores comunitarios y la revolución industrial. Fue un reflejo de la acumulación capitalista naciente en que el individuo tiene una cantidad determinada de energía que es necesario emplear bien; de lo contrario, al igual que los ahorros, la energía puede consumirse y el sujeto "menguar" (Sontag 2003 [1977]: 65). Finalmente en el siglo XX, el cáncer y el sida constituyen las enfermedades propias de las dos últimas fases del capitalismo: por un lado, la que tiene que ver con la prolongación de la vida humana y la invasión de agentes de polución; por el otro lado, el capitalismo tardío en que las fuerzas productivas alcanzan su límite de crecimiento y se generan nuevas y más intensas condiciones de contacto entre las poblaciones de los diferentes sectores mundiales (Páez 104-5).

En cualquier caso, lo que verdaderamente es importante es que estas enfermedades epocales no son sino representaciones sociales que se construyen discursivamente y que alcanzan masividad y se sostienen a nivel comunitario porque conllevan una operación política de estigmatización sobre la cual se sustentan procesos de culpabilidad y exclusión ${ }^{111}$.

Como es de esperar, uno de los discursos principales en este proceso, al menos en lo que atañe a la cultura occidental, es el científico-médico ya que, en la conjunción que a menudo suele formar junto al discurso moral,

${ }^{111}$ En su ya clásico trabajo, Erving Goffman distingue entre tres tipos de estigmas: las deformidades del cuerpo, los defectos del carácter del individuo que se perciben como falta de voluntad, pasiones tiránicas o antinaturales, creencias rígidas y falsas y, por último, los estigmas tribales de la raza, la nación o la religión. A pesar de estas diferencias, existe un rasgo sociológico común. Goffman afirma: "un individuo que podía haber sido fácilmente aceptado en un intercambio social corriente posee un rasgo que puede imponerse por la fuerza a nuestra atención y que nos lleva a alejarnos de él cuando lo encontramos, anulando el llamado que nos hacen sus restantes atributos" (15). 
constituye uno de los dispositivos más importantes en la construcción normativa de las sociedades modernas secularizadas. La etiología, que es la rama de la medicina que estudia las causas de las enfermedades, cumple un papel preponderante en este sentido en tanto es la encargada de "instruir" acerca de qué cosas son nocivas para la salud y, por consiguiente, cuáles son los modos de preservarla. Asimismo, también otros tipos de discursos menos relacionados con la perspectiva objetivista del campo de la medicina crean las reglas en torno a tabúes cuyo desacato puede ser la causa de una enfermedad (Anz 2006: 41).

La literatura, por su parte, si bien ha tenido en la construcción de la representación social de la enfermedad un papel de relevancia singular, no ha sido en todos los casos con la función normativa con que se desarrolló el discurso médico. Por el contrario, tal como veremos en la narrativa sarduyana, el discurso literario puede ser la forma elegida para trascender el afán clasificatorio y disciplinario de la medicina occidental en aquellos casos en los que de lo que se habla es mucho más que una enfermedad o un estado que perturba la salud de un sujeto. Dicho de otro modo, cuando la enfermedad es un "mal" al que ni siquiera se puede dar un nombre preciso, el discurso científico es inoperante porque su bagaje teórico lo encarcela en parámetros que son del todo excedidos por la inconmensurabilidad de ese mal. La única respuesta posible, entonces, parece ser la literatura, la inquietante virtud de la literatura de excederse a sí misma y hablar mucho más allá de lo audible, de lo legible, hablar desde el goce... y el dolor.

En un sentido algo diferente, según Jochen Hörisch "quien enfoca las patologías desde la literatura alimenta esperanzas de obtener al menos tesis 
explícitas sobre la relación entre una patología de la época y una patología individual" (2006: 57).

Como sea, es evidente que el discurso literario y la literatura no se han quedado al margen de una de las problemáticas más fundamentales de la existencia humana al punto que, como ha sido claramente desarrollado en el trabajo de Susan Sontag, la metáfora es uno de los recursos más utilizados en esta construcción discursiva de las enfermedades iniciando, de esta manera, un proceso que culmina, una vez metaforizada la enfermedad, con su adjetivación de modo que se constituye en un atributo que sirve para caracterizar el horror de otras cosas o situaciones. Se habla, entonces, del "cáncer" de una sociedad, de un gobierno, de una comunidad; de "virus" informáticos que "infectan" las máquinas; de "contagios" ideológicos o conductuales, etc. (2003: 61)

Así, las enfermedades de época suman un plus de significados a la información de las que son portadoras. Desde los griegos en que la enfermedad podía ser un castigo sobrenatural, gratuito o merecido se pasó al cristianismo en que la correspondencia entre la enfermedad y el sujeto enfermo se hizo cada vez más estrecha por lo que ésta se interpretó no sólo como un castigo sino como un castigo justo y apropiado. Por otra parte, en el siglo XIX, la enfermedad es una expresión del carácter, un resultado de la voluntad del individuo enfermo por lo que, poco a poco y a medida que los sentimientos excesivos se hacen aceptables, la enfermedad se transforma en su metáfora, reveladora de aquellos sentimientos que el sujeto mantenía ocultos (49-50). 
Por su parte, la época actual se caracteriza, fundamentalmente, por las explicaciones psicológicas de las enfermedades que permiten manipular experiencias y hechos sobre los que, en verdad, no hay control o es escaso. Según Sontag, la psicología es, en este contexto, una forma sublimada de espiritualismo, "una forma laica y ostensiblemente científica de afirmar la primacía del "espíritu" sobre la materia" que busca otorgar una respuesta no sólo a la realidad de la enfermedad sino, más allá aún, a la muerte misma que ha adquirido, ante la ausencia de naturalidad o consuelo religioso, el carácter de misterio obsceno e ingobernable (59).

Poner la explicación de los males que afectan a la salud en la mente es un procedimiento que ha tenido más de una consecuencia. Por un lado, se amplió la categoría de enfermedad al punto de que cualquier forma de desviación social puede ser considerada una patología lo que puede hacer que un comportamiento criminal o violento sea comprendido desde el punto de vista médico y, por lo mismo, no condenable sino "curable". Por el otro lado, el hecho de que una patología sea interpretada psicológicamente implica un mensaje según el cual el individuo se enferma porque inconscientemente así lo quiere como así también, si quiere, puede curarse. De este modo, mientras que la primera interpretación desresponsabiliza al sujeto por sus actos, aún cuando puedan ser delictivos desde el punto de vista legal, la segunda lo culpabiliza $(60)^{112}$.

\footnotetext{
${ }^{112}$ Un ejemplo muy claro de "psicologización" de la enfermedad, en este caso el sida, es el trabajo de Laura Billiet H.I.V.-S.I.D.A. La época de inmunodeficiencia en el que la autora aborda el tema del contagio y la enfermedad desde un punto de vista psicosomático utilizando como uno de sus conceptos fundamentales la idea de "identidad sexual en estado de indigencia" a partir de la cual afirma, como una de sus tesis principales, que "no se trata de que la "desestructuración psíquica" se "produzca ante el impacto de saberse "reactivo" al HIV". La inmunodeficiencia inicial a la que alude un contagio ya "es" manifestación de una biografía en proceso de desestructuración" (1995:11). Si, como afirma Sontag, psicologizar la enfermedad es un procedimiento que acarrea consecuencias de relevancia en cuestiones
} 
Con un pasado tan incierto como su futuro, el sida es la enfermedad de las últimas décadas del siglo $\mathrm{XX}$ que más debates y discursos ha suscitado. Según Graciela Biagini, más que como un problema de salud pública, el imaginario social en torno del sida se construyó en función de un discurso médico y epidemiológico en consonancia con la tendencia a establecer taxonomías que instaló la idea de que se trata de un "fantasma, fenómeno apocalíptico, "peste rosa" o entidad maligna" (2009: 21). En este mismo sentido, según Sontag, es la característica particular de enfermedad que en verdad reúne una lista indefinida de otras enfermedades lo que hace del sida una patología cuya identidad fue diseñada con fines de investigación y tabulación por lo que, más que cualquier otra, es fruto de una construcción que reúne una multiplicidad de significados y representaciones ${ }^{113}$. En principio, se puede establecer una genealogía metafórica dual en tanto establece parentescos, por distintos motivos, tanto con el cáncer como con la sífilis: con el primero, porque se lo describe como invasión; con la segunda, porque cuando se hace referencia a la transmisión de la enfermedad, se invoca la metáfora de la polución (103).

de culpabilización y responsabilidad, creo que lo más fuerte en este sentido queda evidenciado en el trabajo de Billiet en la siguiente afirmación: "Quienes se exponen al contagio parecen buscar una "hermandad" que los mancomune. En este caso, la comunión se manifestaría en la amalgama HIV-huésped" (163).

Por el contrario, en el trabajo SIDA GLOBAL: Verdades y mentiras. Herramientas para luchar contra la pandemia del siglo XXI (2003) Alexander Irwin, Joyce Millen y Dorothy Fallows se proponen desmontar los principales mitos que rodean a la problemática del sida. Abordan, entonces, cuestiones como las desigualdades sociales y sus consecuencias en la prevención y tratamiento de la enfermedad, la culpabilización a ciertos grupos sociales por considerarlos agentes "privilegiados" de transmisión, las (im)posibilidades reales de prevenir y tratar seriamente la enfermedad en países del tercer mundo, las razones económicas que se ocultan detrás de las políticas farmacológicas y de salud pública promovidas e implementadas, etc. Se trata de un trabajo de envergadura política que saca a la enfermedad del discurso científico-médico pretendidamente objetivante y la pone en consideración junto a las problemáticas históricas, sociales, económicas, políticas y culturales en las que está inmersa.

${ }^{113}$ El sida es un síndrome constituido por alrededor de 25 o 30 enfermedades degenerativas y neoplásicas conocidas que resultan de una inmunodeficiencia debida a la reducción de células T (Billiet 45). Son las llamadas "enfermedades oportunistas". 
En cualquier caso, es una enfermedad que no da lugar a la romantización ni a la semantización como ficciones compensatorias sino que, por el contrario, se encuentra inmersa en una representación que conjuga culpa, vergüenza, estigmatización y exclusión ya que, si por un lado se considera que el contagio se debe a comportamientos peligrosos, indulgentes y, en algunos casos, delictivos, por el otro, y como consecuencia directa de esto, las personas afectadas por la enfermedad son consideradas como pertenecientes a algún "grupo de riesgo". Se constituye así una identidad en torno a la patología que tiene la particularidad de "hacer brotar" identidades que, de existir, podrían haber permanecido ocultas por elección personal del individuo. En el mismo momento, se pone en marcha un proceso mediante el cual estos llamados "grupos de riesgo" son estigmatizados en razón de cualquiera de los tres aspectos señalados por Goffman: el cuerpo, el carácter o las creencias o ideologías ${ }^{114}$. De este modo, gays y lesbianas, drogadictos y extranjeros —en su más amplio sentido- son los primeros "sospechosos" y a quienes se les atribuyen las mayores responsabilidades en la transmisión y propagación del sida. Para conseguirlo, se produce en los tres casos una "hipercorporalización" (Llamas 1994) de los sujetos — que es lo mismo que decir "una reducción al cuerpo"- a través de la cual se pone en marcha este régimen de sujeción que incluye la sexualidad, el color, la clase social, las normas higiénicas y médicas y que permite no sólo estigmatizar y excluir sino también adoptar el problema del sida como propio de algunos pocos —indeseables - aunque

\footnotetext{
${ }^{114}$ Una de las formas más notorias de estigmatización fue el establecimiento, desde las primeras apariciones de la enfermedad, de las cuatro $\mathrm{H}$ como alusión a los principales grupos de riesgo que aluden a homosexuales, haitianos, hemofílicos y heroinómanos. Otro ejemplo en este sentido es que la prensa norteamericana y europea identificó la enfermedad en sus inicios como "cáncer gay".
} 
con la capacidad de afectar a muchos: "Ésa es la extraordinaria potencia y la eficacia de la enfermedad de la peste: permite ver una enfermedad a la vez como algo en lo que incurren los vulnerables "otros" y como (potencialmente) la enfermedad de todos" (Sontag 146) ${ }^{115}$.

Sin embargo, esto no parece ser lo peor. La reducción a sólo cuerpo de los individuos también permite naturalizar la enfermedad y la muerte, aunque sólo para algunas personas, en un momento histórico que se resiste fervientemente a aceptarlas y que lucha con todas las armas de la ciencia y la economía para rebatirlas.

Si bien ya desde el siglo XIX se produce una localización del dolor y la muerte en la "homosexualidad" como una de las formas de situarla lejos de la comunidad "normal", es a partir de los años ochenta del último siglo y a través, precisamente, del sida que estos se asocian con más vigor ${ }^{116}$. Así, las personas que mantienen relaciones homoeróticas son caracterizadas a partir de una "esencia" funesta, autodestructiva, vinculada a un destino trágico al que siempre parecen tener deseos de cumplir. Esta fatalidad

115 Paradójicamente, este proceso de "hipercorporalización" tuvo su correlato en las políticas económicas neoliberales de los años ochenta en adelante en un proceso contrario mediante el cual, según Christian Gundermann, la homosexualidad fue liberada de la materialidad del cuerpo ligado a la reproducción por lo que se transformó en símbolo de un deseo que existe y se propaga por sí mismo (2003: 132). En tal sentido, Gundermann se propone abordar "textos que desarrollan estrategias de resistencia melancólica, por un lado, contra la cultura de deseo y consumo y, por otro, contra la extraña exclusión del cuerpo concreto que se lleva a cabo en esta cultura neoliberal" (ídem). Con este propósito, analiza la obra de Néstor Perlongher a partir de la cual desarrolla una crítica de las políticas del deseo y de las teorías queer que han puesto sus fundamentos en los paradigmas dominantes de la cultura neoliberal de los noventa argumentando que "A diferencia del paradigma norteamericano queer dominante, el modelo de liberación homosexual reclamado por Perlongher no permite que se desvincule la liberación homosexual del proyecto revolucionario basado en las reivindicaciones materiales de las clases trabajadoras" (135).

116 Adrián Melo, en El amor de los muchachos. Homosexualidad y Literatura (2005), recupera historias de amor entre hombres, y las distintas formas artísticas en que se han manifestado, en las que la tragedia es una constante que persiste desde la antigüedad griega hasta la actualidad. Así, la imposibilidad del final feliz en las historias que involucran el amor homoerótico se repite tanto en la literatura como el cine y contribuye a reforzar el imaginario de "esencias autodestructivas" que se construye en torno a la figura de la homosexualidad. 
inexorable -que el régimen heterosexual nunca identifica con las desigualdades de condiciones en la prevención y el tratamiento de la enfermedad, ni con la discriminación, ni con ninguna de las circunstancias sociales, económicas, culturales y políticas que rodean a la enfermedad y que la hacen especialmente agresiva para algunas personas y menos preocupante para otras - es lo que en realidad permite que, y casi rozando la morbosidad, la única muerte representable sea la del "homosexual". Ésta cumple una función simbólica importante ya que tiene la determinación de poner de relieve la vida que sí debe considerarse merecedora de ser vivida (Llamas 1998: 143-4). De este modo "La muerte del perverso confirma su alienación; su radical extranjería con respecto a la "normalidad" social" por lo que su representación se establece como una profecía que "se realiza porque se representa, y que se representa porque se realiza" (155).

Sin embargo, según Llamas, esta misma muerte es la que, paradójicamente, como fenómeno socialmente relevante termina por reconciliar al "homosexual" con su entorno ya que vuelve la hostilidad en compasión o espectáculo edificante (148). Es por esto que, aunque no haya referentes positivos para las personas gays o lesbianas, es posible pensar en este "imaginario desdichado" como un posible espacio de autonomía donde afrontar la muerte presenta formas que se alejan a menudo de las tradiciones funerarias del duelo silencioso:

hacer de la muerte una obra de arte, una fiesta, un chiste, un manifiesto político, un acto de protesta, la excusa para una revuelta, en definitiva, cualquier cosa que no la reduzca a ese atributo inevitable al destino, cualquier cosa que no sea la confirmación de un estereotipo, cualquier cosa, por último, que no la deje en la ignominia (164). 
En resumidas cuentas, "subjetivizarse", establecer bases de autonomía, destruir el "cuerpo homosexual" son requisitos indispensables de ética y de salud pública pero sin que esto implique recaer en el extremo de renunciar al cuerpo. Porque ésta es una estrategia ya implementada por algunos grupos gays que, según Llamas, ha tenido consecuencias perniciosas en tanto se esencializó la enfermedad y resurgieron ciertos prejuicios de los años setenta como "el sexo como consumo alienante, "el ambiente" como gueto, como cárcel o espacio comercial de libertad vigilada, la "identidad" como confirmación del estigma, la pluma como expresión de misoginia... Pero no se logró parar el Sida” (167-8).

Hacer de la de la muerte, de la enfermedad una obra de arte. Hacer del arte, de la escritura, de la pintura una construcción de autonomía, de subjetividad. Subjetivizarse y hacer una política... 
III. 6. Si las palabras toman cuerpo... Pájaros de la playa: escritura y subjetividad

A pesar de estos andamiajes, me queda una última libertad, la de insurgirme contra el desorden divino, contra el simulacro de la armonía universal. Ante la indiferencia de Dios caen fulminados hombres y pájaros. Las víctimas se escogen al azar, como en una galaxia el astro que va a consumirse.

[...]

- Somos -resumió- el sueño abortado de un demiurgo menor, simpaticón y de buena voluntad, pero más bien torpe. Casi todo le salió al revés, o inútilmente complicado, o aproximativo, o chato...

Severo Sarduy, Pájaros de la playa (1993).

La construcción de la propia imagen es un procedimiento que llevan a cabo los escritores en el límite de sus propios textos, condensando, de manera más o menos explícita, proyecciones, autoimágenes o contrafiguras de sí mismos. En éstas se puede leer una variedad de problemas concernientes al lugar que el autor se otorga, tanto en el seno de la sociedad como respecto al campo intelectual y al ámbito de la literatura a los que pertenece (Bourdieu 1971). Una lectura que revea estas problemáticas debe apuntar, en consecuencia, hacia una serie de variables que entran en juego en dicha construcción y que configuran la sociedad, el campo intelectual y 
la literatura como lugares de emergencias de discursos heterogéneos que interactúan en constante lucha por lograr $\multimap$ o mantener— la hegemonía de unos sobre otros. Es así que, la relación que el autor mantiene con sus pares —contemporáneos o futuros-, con los lectores, con las instituciones o el mercado; las genealogías que construye y a las cuales se inscribe u opone; la manera en que se vincula con todas y cada una de las instancias extraliterarias ante las que está expuesto — sectores sociales e instituciones políticas, entre otros - son algunos ejemplos de estas variables que deben ser tenidos en cuenta a la hora de abordar la construcción de la subjetividad de escritor en la literatura (Gramuglio 1992).

Severo Sarduy fallece, enfermo de sida, en el año 1993 y nos deja una intensa y prolífica obra en la que, no importa el género, algunos temas/ problemas se van repitiendo incesantemente hasta construir, por sí solos, una cosmogonía escrituraria particular. Pájaros de la playa (1993) establece un recorrido de este universo escriturario poniendo en relación aquellas problemáticas que han sido constantes en la totalidad de su obra. Este nuevo camino, de alguna manera, retrospectivo, le permite examinar y recuperar su trayectoria artística a través de la construcción discursiva de una imagen de intelectual desde una doble vertiente: la del artista — ya sea el escritor, ya el pintor-y la del hombre.

A diferencia de algunos de sus trabajos anteriores — por ejemplo, Cobra —, podemos decir que la trama argumental de Pájaros no constituye un problema para el abordaje de la obra ya que, si bien se producen algunas rupturas, las categorías de la narración —espacio, tiempo, personajes—son, en principio, fácilmente reconocibles. El nudo de la historia se desarrolla en 
un hospicio en el que personas de distintas edades y de ambos sexos luchan cotidianamente contra uno de los males que más preocupa al hombre posmoderno: el cuerpo y su posible corruptibilidad ${ }^{117}$. Ésta se produce en la novela como consecuencia de dos situaciones diferentes. Para el Cosmólogo y casi la totalidad de los personajes, la destrucción corporal viene de la mano de otro mal que si bien nunca es nombrado, queda claro que alude al sida. Para Siempreviva, en cambio, la corruptibilidad es un efecto de la vejez y no de la enfermedad. En todos los casos, el núcleo argumental es el sometimiento inescrupuloso que sufre el cuerpo frente a prácticas — medicinales unas, cosméticas otras- que pretenden mantenerlo fuerte y joven pero que no consiguen más que llenar de emplastes la marcha inexorable hacia la aniquilación total ${ }^{118}$. Así, los moradores del hospicio, aunque dedican su vida entera al cuidado del cuerpo, no pueden más que definirse en relación a su decrepitud contrapuesta a los visitantes sanos de la playa cercana:

EN LA ARENA rojiza dejaban un momento sus huellas los pies fuertes de los corredores. Pasaban veloces, concentrados en el ejercicio, como si pensaran en cada músculo que contraían, atareados en esa ofrenda cotidiana a la salud. Los cuerpos tensos brillaban excesivamente dibujados, casi metálicos, barnizados por el sudor, en mechones mojados, el pelo se les pegaba a la piel.

Se alejaban sin mirar siquiera un momento a los raros bañistas que tomaban el sol, o que se reponían de los titubeos etílicos

\footnotetext{
117 La idea de hospicio/ hospital como lugar donde "internar" -encerrar, excluir, agregaría- aparece claramente en Сосиуo, cuando toda la familia ingiere matarratas, como así también en el hospicio en el que permanece el personaje -y donde encuentra a Ada y ésta será prostituida cuando se escapa del hospital. Pero creo que también puede ser pensada en Colibrí ya que, en algún sentido simbólico, la Casona es ese lugar donde las "ballenas" permanecen encerradas en el sopor que les produce la droga y los excesos.

${ }^{118}$ Estela Sagredo analiza cómo el cuerpo ha sido puesto en escena por la posmodernidad — perdiendo de este modo su cualidad "judeo-cristiana de templo divino, de espacio privado y sugerente" - mediante la mutación constante a la que es expuesto, ya sea por tatuajes, cirugías, cosméticas, etc. en "Cuerpos mutantes" Revista del Ateneo Psicoanalítico ( $\sin$ otros datos).
} 
de la noche anterior con el aire del litoral [Mayúsculas en el original] (Sarduy 1999 [1993]: 917).

A nivel del discurso, las rupturas mencionadas son las encargadas — como era de esperar para una obra sarduyana— de borrar esta claridad argumental. En este sentido, una de las problemáticas que primero aparece planteada es la de la dicotomía ficción/ realidad ${ }^{119}$. Ésta se presenta en el texto a partir de la confluencia de un abanico de diversos géneros discursivos acuñada, no a partir de los elementos paratextuales —con excepción de aquellos que nos permiten identificar el género novela y de la organización en verso de los poemas finales—, sino a través de la voz del narrador que, si bien por un lado funciona como elemento de cohesión del relato, por el otro, y a raíz de que poco a poco se va entrometiendo en el entramado textual hasta cobrar una importancia singular, constituye un factor de diferenciación y dispersión genérica.

En primer término, en la instancia enunciativa correspondiente a la novela, autor y enunciador son dos agentes diferentes entre sí. La voz que prevalece es la de un narrador omnisciente que desde afuera ve transcurrir la vida de los hospitalizados y la relata haciendo uso de los artilugios del lenguaje que la literatura le permite. En esta instancia, el narrador asume una actitud de oposición con respecto a los enfermos de la isla: "MÁS ALLÁ de la autopista se encuentran los otros, los que la energía abandonó” [Mayúsculas en el original] (920). El exilio que, como he intentado

\footnotetext{
${ }^{119}$ Es necesario aclarar que lo que aquí se presenta como dicotomía es un procedimiento que implica una gama amplísima de alternativas en la que los dos términos se interrelacionan en un juego constante cuyo único objetivo es la destrucción de toda frontera preestablecida. La presentación en opuestos binarios tiene como finalidad la simplificación y claridad de la exposición.
} 
demostrar, constituye un elemento estructural de toda la obra de Sarduy, aquí se plantea como resultado del límite geográfico que impone la autopista.

En segundo lugar, la puesta en escena de la situación de enunciación denuncia la presencia de un discurso metacrítico en el que ambas voces se superponen y se confunden. Así, la voz sarduyana ocupa un lugar que poco a poco va conquistando, desde la inclusión de la primera persona y el uso de deícticos hasta la intromisión más jactanciosa de los meta-comentarios: "Economicemos los pormenores, que sólo sirven para entorpecer la narración, derivando hacia lo anecdótico secundario la mariposeante atención del lector" (951). Por medio de estas declaraciones, que en algunos casos parecen puro juego del lenguaje, Sarduy asume una postura clara frente a lo que debe ser la literatura, que no es más que la puesta en evidencia de aquello que en la totalidad de su obra es una vertiente constitutiva. Es decir, explicita una concepción estética que, fuertemente relacionada con las teorías del grupo formado en torno a Tel Quel y deudora de algunos de los padres de la tradición neobarroca cubana, ubica su escritura en el paradigma de la literatura no representacional y, por lo mismo, fuera del canon del realismo social instaurado por los intelectuales de la Revolución:

En los relatos puede lo pésimo postergarse, diferirse lo ingrato y hasta anularse, por más congruente que parezca, el desenlace final. El mimetismo intimida a más de uno y convierte su historieta en un amasijo de verdades comprobables, pero que se borran con el punto final (932). 
Finalmente, hay un espacio donde la tercera persona es reemplazada por la primera: "HAY DÍAS en que al despertarnos, la energía está allî" [Mayúsculas en el original] (974). A partir de este capítulo, comenzamos a sumergirnos en el interior de una historia que sospechamos conocida: escuchamos el reclamo de un hombre acosado por el mal. El DIARIO DEL COSMÓLOGO se convierte en el diario de Sarduy y descubrimos, entonces, que desde la escritura ficcional de la novela hemos sido conducidos sutilmente hacia una escritura que en algún sentido podría denominarse autobiográfica o confesional ${ }^{120}$. Así, desde el espacio público de la obra literaria nos hemos desplazado hasta la privacidad del hombre. En resumen, hemos recorrido un camino en el que el artista comparte su lugar con el crítico, con el hombre y, más adelante, lo hará también, con el yo más íntimo y subjetivo, el de la poesía:
A la luz sin peso,
al día sin bordes
ni comienzo,
los ojos voy a abrir
Cesar del pensamiento,
sustraída la imagen,
su brutal sucesión,

\footnotetext{
${ }^{120}$ La cuestión de la escritura autobiográfica ha generado un intenso debate aún vigente al que no pretendo dedicarme aquí. Sin embargo, en relación con el tema que me ocupa especialmente, considero interesante una reflexión de Birger Angvik en la que afirma: "La literatura confesional y/o autobiográfica parece invitar, en momentos de crisis y de rupturas, a establecer una especie de equilibrio entre lo general y lo individual al textualizar los (de)-efectos diseminados, por ejemplo, por "plagas" en el "mundo" sobre el cuerpo y el alma individual. Esta persona individual aparece como textual, víctima de las consecuencias textualmente producidas y "escena" textual sobre la que se desarrollan dramáticas peripecias" (2006: 38).

En "Diario de la peste" y "El estampido de la vacuidad" — ambos textos escritos contemporáneamente a Pájaros de la playa y publicados también después de su muerteSarduy reflexiona sobre el cuerpo en relación con el sida a través de la narración de su propia experiencia como enfermo. Esto le otorga a los textos un alto valor testimonial ya que cuenta en ellos tanto sus internaciones en los hospitales y los tratamientos a los que fue sometido como sus sentimientos y sensaciones en torno a la enfermedad.
} 
y hasta el deseo

[...] (1003).

De este modo, en este camino de conocimiento y reconocimiento que juntos, autor y lector llevan a cabo, un personaje se va sumando lentamente al andar. El cuerpo propio, el de la primera persona, cobra importancia singular a partir del cuerpo de los otros. Es decir, los cuidados proferidos a Siempreviva, uno de los principales personajes de la novela, son los que sufre el Cosmólogo. En un caso, el primero, el accionar terapéutico tiene como finalidad reconstituir una juventud perdida hace ya mucho tiempo. En el otro, vendajes y transfusiones de por medio, se entabla una lucha despiadada contra la enfermedad; una lucha en la que el yo y el cuerpo son dos enemigos cuya única conciliación posible es la inminente muerte: "Antes disfrutaba de una ilusión persistente: ser uno. Ahora somos dos, inseparables, idénticos: la enfermedad y yo" $(977)^{121}$.

Si la voz enunciativa nos permite ver a Sarduy desde tres aspectos diferentes, como novelista, como crítico y como poeta, los personajes de la novela nos proponen otros posibles acercamientos a la construcción de la imagen de artista del autor cubano. El cosmólogo, el arquitecto y Siempreviva son los protagonistas y "hacedores" de un relato que continúa durante, por lo menos, cuarenta años. Un relato que, como ya dije, resignifica elementos estructurantes de toda la obra sarduyana: la escritura, el cuerpo, la pintura y el cosmos: "Todos esos signos tejen [...] un entramado de correspondencias simbólicas: el cuerpo como emisor/ receptor

\footnotetext{
${ }^{121}$ Esta relación que establece el sujeto con su propio cuerpo es similar a la que se da en
} Cobra. 
de lenguaje, el cuerpo como engranaje esencial del cuerpo cósmico y el cosmos como cuerpo legible" (Ulloa y Ulloa 1999: 1630).

El arquitecto, amigo de la juventud de Siempreviva, construye una casa subterránea para escuchar el estallido inicial del universo y reencontrarse con el origen de todo lo creado. Pero este reencuentro no puede producirse ingenuamente y sin mediaciones sino que sólo se lleva a cabo por medio de un lenguaje inscripto sobre un soporte, en este caso, la pintura sobre el mismo cosmos: "Pintar. Pintar animales en las piedras según sus relieves. Para volver al origen de todo” (947).

Sobre el cosmos o sobre el cuerpo, a modo de tatuajes, la pintura es la otra forma de creación posible, alternativa y complementaria a la escritura. Sarduy es un pintor de cuadros pero también es un pintor de textos o, lo que es igual, un escritor de imágenes: "Escribir es pintar. Lo último que queda, una vez terminada la página laboriosa, ajustados los sucesivos párrafos, las frases rápidas, las palabras corriendo como en la cresta de su propio oleaje, es una imagen" (1999 [1990b]: 34).

El cosmólogo, por su parte, joven avejentado por el mal, también es un creador, aunque paradójicamente, su creación está íntimamente relacionada con la destrucción. Historiador de la enfermedad, el cosmólogo lleva en su escritura el estigma de su propia descomposición y en razón de ella re-escribe aquel relato que el arquitecto había comenzado, sólo que ahora el encuentro que se produce ya no es con el origen sino con la nada, con el vacío final de la muerte: "el astrónomo se había encerrado a pan y agua en su celda para redactar un diario sobre la extinción del cosmos y su metáfora: la enfermedad" (1999 [1993]: 960). 
En los protagonistas de este relato del principio y el fin del cosmos, del cuerpo y de la escritura, el cosmólogo y Siempreviva, la vieja rejuvenecida por la magia de los emplastes, recae el intento de reconstitución del cuerpo perdido a causa de la enfermedad o de la vejez. Por placer y por dolor, éste se impone tiránicamente y ya no es posible desentenderse de él: "El cuerpo se convierte en un objeto que exige toda posible atención; enemigo despiadado, íntimo, que sanciona con la vida la menor distracción, el receso más pasajero" (975). Por esto, es necesario someterlo a la acción de tratamientos terapéuticos o estéticos: curar o simular:

- Lo delata el olor -observó hundiéndose en el agua tibia-, ese tufo reconocible de las clínicas y los quirófanos: han puesto en el baño un poco de agua desinfectante...

- Es verdad -reconoció el acólito-, pero poca y disimulada con champú.

- Eso no impedirá -concluyó irónica Siempreviva- que el cuerpo prosiga su proceso, que es ir, aún en vida, hacia la pudrición (938).

Estos tratamientos aplicados al cuerpo en descomposición, constituyen, a nivel textual, otras estrategias discursivas mediante las cuales Sarduy recupera elementos de su obra anterior. Citas, intertextos, juegos gramaticales, retóricos y fonéticos, metamorfosis de los personajes, simulación y proliferación son algunos de los procedimientos que ponen en jaque la claridad de la novela y la cubren de brillo y desmesura con el fin de recordar lo que ya no será, construir lo que nunca fue y ocultar -a medias-develando - a medias- lo que se quiere y no se puede ${ }^{122}$. Una vez

\footnotetext{
${ }^{122}$ Para un análisis detallado de estos procedimientos textuales ver Ortega, José. (1994). "La imaginación neobarroca de Severo Sarduy en Pájaros de la playa". Monographic Review/ Revista Monográfica. X: 110-119.
} 
más, entonces, la escritura es inseparable del cuerpo, con relación al placer, cuando se trata de Siempreviva:

La piel no fue límite, ni la consciencia: todo se anudó en un garabato incomprensible y furioso como un ideograma, sin otra voluntad que el placer, sin más fin que el goce en su borrosa inmediatez (930).

con relación a la enfermedad, cuando del cosmólogo hablamos: "Me sorprendo evocando un cuerpo en medio de todas esas tachaduras, borrones y denegaciones de la vida" (967).

Así, mal, garabato y placer; cuerpo, escritura y enfermedad son los fundamentos de un proceso que implica, al mismo tiempo, dos elementos opuestos: constitución y descomposición, develamiento y maquillaje, es decir, son los términos que permiten crear un nuevo sentido pero ya no como totalidad sino como punto de fuga, como intersticio por el que se cuelan la fragmentación y la pluralidad. Desde la dispersión de voces y de géneros, desde el lenguaje excesivo, proliferante, cuya única finalidad parece ser la de reenviarse a sí mismo, se difuminan los límites de la trama, de los sujetos; se confunden realidad y ficción, obra y vida, principio y fin de una historia y de una figura. Y se construye, entonces, una nueva imagen de la Literatura, de la Historia y del Sujeto, polivocales, heterogéneos, excluidos.

Desde una escritura marginal a los cánones de la literatura representacional, desde los bordes lingüísticos y textuales, desde un modelo corporal y sexual disidente con un prototipo de hombre culturalmente preestablecido, Severo Sarduy, intelectual, escritor, pintor, exiliado... 
disonante en todas las expresiones posibles, revisa y reconstruye su trayectoria artística para escribir su propia imagen, pintar su escritura...

El exilio, el cuerpo y la escritura, el artista, el intelectual y el hombre confluyen allí donde:

El espacio literario es [...] espacio para la subversión. Los textos albergan simultáneamente voces culturales distintas, cosmologías contrapuestas, y se cuestionan desde su propia sustancia mestiza las versiones unívocas de la realidad (Adrián 1994:15).

Por otra parte, los cambios en la voz enunciativa dan cuenta de una nueva manera de relacionarse con el cuerpo, esta vez, la que corresponde a un enunciador ambiguo: narrador/ Cosmólogo/ Sarduy. Así, la narración pone a este sujeto enunciador en el centro de la escena con la finalidad de reflexionar, de ser el conocedor del mal, y éste lo hace de una forma particular, diferente a las maneras de la ciencia tradicional: apela a los sentidos y las percepciones antes que a la razón por lo que la mirada y el olfato — pasos previos de la investigación científica—son validados como formas de conocimiento:

Una solución de albahaca y verdolaga, que se dejaba gotear en los ojos cuatro veces al día, le dilató las pupilas y le dio a su mirada la agudeza de quien contempla las cosas no en su relumbrona superficie, sino en el centro indecible de su identidad (932).

Lo delata el olor —observó hundiéndose en el agua tibiaese tufo reconocible de las clínicas y los quirófanos: han puesto en el baño un poco de agua desinfectante... (938).

Asimismo, la voz y, consecuentemente, la oralidad, son asumidas como lenguajes diferentes y alternativos a la escritura alfabética: "No puedo remediarlo —ni lo intento-: la voz es la verdad del cuerpo, un testigo despiadado aunque inmaterial, siempre ajeno" (976). 
Como consecuencia de esta forma de conocer a través de lo sensible, el cuerpo pierde su condición de objeto medible y mecánico propia de las concepciones modernas pero accede a un estatus que le había sido negado en favor de la mente y se proyecta hacia la construcción de un nuevo sentido que implica reivindicar dos aspectos históricamente disociados entre sí: el placer y la producción de significados. Esto es, reconocer, por un lado, el mandato relacionado con el derroche erótico y la carencia de funcionalidad, y por el otro, el de la visión economicista que apunta a su función reproductiva. Sarduy retoma a ambos en Pájaros de la playa y nos propone, a partir de ellos, dos caminos posibles de lecturas que en apariencias siguen esta dicotomía pero que, sin embargo, concluyen en un planteamiento que desborda y excede — siguiendo su propia terminología— esta pretendida bipolaridad.

El primero de estos caminos es el que, entre un cuerpo "útil" y uno que, según parece, "no sirve para nada" levanta el fantasma de lo corporal en su devenir a través del tiempo, el de la transitoriedad que esto implica y la certeza de que, finalmente, siempre hay un cuerpo real y otro imaginario, uno que se instituye en el tirano de nuestros días —l que hay que curar, limpiar y maquillar - y otro que no es más que una construcción mental que alimenta y mantiene vivas las, en el caso de los hospitalizados de Pájaros de la playa, (des)ilusiones. Así lo demuestra el Cosmólogo quien se autoproclama "historiador de la enfermedad", en representación de todos los enfermos del hospicio, y evoca su cuerpo del pasado para anotar sus cambios y registrar los síntomas de la enfermedad, pero también, en pos de 
una imagen ya perdida $\longrightarrow$ que tal vez nunca existió- a la que pretende recuperar en sus ejercicios $\operatorname{cotidianos}^{123}$ :

Se fijaban un objetivo: la imagen de sí mismos vestidos, recién lavados, afeitados, sanos y perfumados, escribiendo, leyendo, alertas y jubilosos frente al sol de la mañana. Trataban de alcanzar esa imagen.......] Algunos lograban llegar hasta el modelo que se habían trazado, hasta esa fugaz felicidad. [...] Otros abandonaban el proyecto después de algunos gestos desajustados, temblorosos (924).

En el mismo sentido, Siempreviva rememora su imagen de otros tiempos en un intento desesperado por restablecer la belleza, la sensualidad y el goce erótico de la juventud:

Mas los cuerpos que se aman jamás son los cuerpos reales, sino otros que suscita y proyecta la imaginación de los amantes. [...] El que yo ahora le ofrecía al Caballo era ese cuerpo imaginario, sin pesadez, astral casi, y no este amasijo de tendones vencidos, de nervios inútilmente alertas, de flaccidez y hastío (930).

Este cuerpo que ya no es una pura materialidad sino una formación discursiva que se cimenta sobre los estigmas propios de la estética —la belleza, la forma - y del placer —el erotismo— es, a nivel discursivo, el cuerpo de una escritura abigarrada y excesiva, descentrada y proliferante, escritura del derroche que elide y evoca, que crea el interrogante pero no la respuesta, escritura barroca.

Así, el cuerpo y la escritura asumen, en la última novela sarduyana, posturas ambiguas y contradictorias a partir de las cuales no es posible

\footnotetext{
${ }^{123}$ En este sentido, es pertinente el análisis de Horacio Costa, aún cuando en su trabajo se refiere a Escrito sobre el cuerpo. Dice respecto de la historicidad del cuerpo: "la absorción de la dimensión pasada es detonada por las asociaciones que la arqueología de las cicatrices, inscritas en el cuerpo del escritor por el tiempo y el azar sugieren. "Escritas" o "tatuadas" en el cuerpo de Sarduy, estas cicatrices, marcas indelebles, ideogramas cuyo sentido sólo puede ser decodificado por él mismo, su portador/ paciente, se transforman en texto trazando un eje significante entre la actualidad de la escritura y el cuerpo del escritor, una comunión entre el cuerpo del lenguaje y su soporte mínimo: el hombre que lo produce y lo padece" (1991: 290).
} 
definir con certeza cuál es el papel que cada uno representa en esta tan estrecha relación. Dicho de otro modo, ni el cuerpo es el humilde servidor de la razón, como se lo ha entendido tradicionalmente, ni la escritura es un instrumento infalible de orden y disciplina. Ambos, por el contrario, constituyen manifestaciones claras de una realidad que es elíptica, oscura y simulada.

En contraposición a esta revisión del pasado, existe también en la obra una mirada que indaga sobre el presente y que forma parte de un segundo abordaje posible. En este caso, el cuerpo deja de ser la evocación de una imagen y recupera la dimensión concreta que tiene la materia en proceso de descomposición. Nos encontramos entonces con que la preocupación central y compartida de todos los personajes es la lucha que contra su propio cuerpo $\longrightarrow$ contra el de los demás como es el caso de los yerberos Caimán y Caballo o de las ambulancieras Auxilio y Socorrodeben llevar adelante cotidianamente. La mirada y la voz vuelven a tener un papel relevante aquí ya que constituyen el punto de inflexión entre aquella imagen perdida y el cuerpo real del ahora, en tanto son los elementos del pasado que permanecen intactos a través del tiempo y como tales, los testigos despiadados de la decadencia del presente: "Algo, sin embargo, les queda del cuerpo en majestad de ayer: la agudeza de la mirada, vultúrido al acecho, tornada hacia lo alto de la cúpula, como en espera de un signo celeste y diurno" (921).

En este sentido, ambas adoptan distintas funciones aunque directamente relacionadas con la problemática de la enfermedad. La mirada, propia o ajena, pone al cuerpo, como objeto de reflexión médica, frente al 
discurso del conocimiento. La voz, por el contrario, asume la última esperanza de rebelión contra el orden que somete a los enfermos al padecimiento, tras una elección que consideran injusta y arbitraria: "me queda una última libertad: la de insurgirme contra el desorden divino, contra el simulacro de la armonía universal. [...] La vocecilla sonó en el corredor, como en una bocina de hojalata" (923).

Así, el cuerpo asumido en función de su materialidad corruptible, de su sometimiento a los, de algún modo caprichosos, avatares de la enfermedad, pierde su condición de objeto y sujeto de placer y conocimiento y se convierte en un obstáculo, torpe e incómodo, que es necesario reprimir y que obliga a instaurar nuevamente aquella vieja dicotomía mente/ cuerpo como única posibilidad certera de reprimir también el sufrimiento:

Mi espíritu ya no habita mi cuerpo; ya me he ido. Lo que ahora come, duerme, habla y excreta en medio de los otros es una pura simulación. El sol anima, es verdad, pero algo en la piel tiene que captarlo, y es eso precisamente lo que desaparece con el mal. Aquí estoy, bajo la colorinesca luz del día, pero ya todo es póstumo. Me escapé del sufrimiento físico (921).

En este sentido, se establece una distinción en el cuerpo que corresponde a lo que Welton (1998), retomando a Husserl, denomina cuerpo físico/ cuerpo vivido, cuerpo bajo una objetivante descripción científica/ cuerpo bajo una descripción experiencial lo que nos permite establecer vínculos estrechos entre Pájaros y Cocuyo ya que es en esta novela donde aparece con insistencia la angustia por el cuerpo como obstáculo, como un resto improcesable con el cual no se sabe qué hacer:

sentía como una evidencia que su cuerpo era una demasía, un exceso inútil, mórbido que mejor sería eliminar para que el mundo recobrara su equilibrio, su armonía inicial. Era como si algo o 
alguien reclamara urgentemente su exclusión, su eliminación en aras de la limpieza y del Orden ideal [...] lo que hay que extirpar" (1999 [1990]: 827).

En esta escisión violenta y obligada, el cuerpo pierde su dimensión social en tanto se convierte en depositario de todo tipo de experimentos. Pero también el yo descarnado sufre estas consecuencias ya que vive y se relaciona sólo en virtud de la enfermedad que lo acosa y con la que entabla una lucha de la que el resultado se conoce de antemano. El sida, entonces, queda de tal manera entronizado entre los hospitalizados de Pájaros de la playa que se instaura como el único espacio posible de relaciones entre el sujeto con su propio cuerpo y de los sujetos entre sí aún entre aquellos personajes que no están enfermos ${ }^{124}$. Así, por ejemplo, aunque Siempreviva se encuentra en el hospicio con la única intención de recuperar la belleza de su juventud, debe soportar los rituales cotidianos de higiene y prevención a los que son sometidos los demás internos. Por su parte, Caimán y Caballo pretenden reemplazar las terapias convencionales de la medicina tradicional por sus propias curaciones a base de todo tipo de yerbas.

Inmersos en esta vorágine desgarradora, la escritura parece ser la única forma posible ya no de luchar contra la enfermedad pero sí de encauzarla, de algún modo, dentro de los parámetros de lo conocido y lo cognoscible. La novela, entonces, es el entramado a partir del cual Sarduy

\footnotetext{
${ }^{124}$ Según Sontag, esta enfermedad "ha servido para crear un espíritu comunitario y ha sido una vivencia que aisló a los enfermos y los expuso al vejamen y la persecución" (2003: 111). La hospitalización y el aislamiento -dado también en el sentido geográficoconstituyen, en la novela, esta instancia por medio de la cual se crea una identidad de "grupo de riesgo" y, agrego, riesgoso, exiliado...excluido... ya que "se entiende que el sida es una enfermedad debida no sólo al exceso sexual sino a la perversión sexual" (112).
} 
lleva a cabo su intento de disciplinamiento (Foucault 1986) del mal ${ }^{125}$. Construye para esto un espacio cerrado - el hospicio, la isla— en el que cada personaje ocupa un lugar preciso — la habitación que lo alberga — una especie de celda que lo mantiene aislado pero, al mismo tiempo, lo suficientemente conectado con el mundo como para poder cumplir con el rol que le ha tocado en suerte y a raíz del cual, adquiere su identidad. Así, el Cosmólogo, el encargado de "redactar un diario sobre la extinción del cosmos y su metáfora: la enfermedad" (960), aún encerrado en su habitación, conoce la vida de los hospitalizados como para registrar en su texto los aconteceres cotidianos. Siempreviva, por su parte, obtiene su nombre por haber sobrevivido a un accidente y tiene como única finalidad dentro del hospicio, extender su existencia a través del rejuvenecimiento permanente.

Como el espacio y los personajes, también el tiempo en la novela es sometido a este proceso de disciplinamiento. En este caso, mediante un procedimiento en el que el enunciador — narrador/ Cosmólogo/ Sarduy— fija ritmos y ciclos, describe minuciosamente las secuencias cronológicas de los actos y establece cierta correlación temporal entre el cuerpo y los gestos y el cuerpo y los objetos que lo rodean. Ejemplos de lo dicho son el paso y la caída de los pájaros que forman parte de un ciclo —el de la vida y la muerte-: "En el conteo aritmético y ramplón que los hombres hacen del tiempo, sólo pasaron tres días, con sus pájaros precisos y el previsible degradado de sus crepúsculos” (936). O las acciones higiénicas y

\footnotetext{
${ }^{125}$ De alguna manera podría pensarse que en este caso Pájaros de la playa funciona como las novelas del siglo XIX en el sentido en que Peter Gay las describe: "fantasías disciplinadas, organizadas, hermoseadas" (1992: 135).
} 
terapéuticas que se transforman en rituales médicos y que imponen un ritmo acompasado y constante a la vida de los hospitalizados:

Pasaban los practicantes el tiempo escrutando orines y excrementos, sudor y saliva. Una meticulosa ciencia de los signos, que excluía la lectura de la sangre y no consideraba más que ciertas materias, el color, la fetidez y la precipitación, les permitía determinar sin vacilaciones qué había que dar a quién, pero sobre todo —éste, decían, es el principio de toda cura— cuándo y cómo (952).

O, finalmente, la secuenciación exacta de cada uno de los movimientos de los enfermos:

Primero: bajar la pierna derecha hasta tocar el piso. Luego, irse enderezando poco a poco, ayudándose de la mano izquierda. Cuidado con las vértebras. Sostenerse al borde de la cama con la mano derecha. Sentados. Alcanzar un calcetín. Ponérselo (924) ${ }^{126}$.

Paradójicamente, cuando más parece que se ha logrado el objetivo esperado, es decir, cuando todo indica que la enfermedad ha sido aprehendida en los límites de la escritura, resulta que algunos datos —de ningún modo menores - quedan todavía sumidos en la oscuridad del desconocimiento o la ambigüedad. Ignoramos por completo su nombre pero también somos ignorantes, en gran medida, de su origen, los síntomas y las terapias en tanto lo que se dice de ellos constituyen vaguedades respecto del discurso científico esperable:

Se ignoraban, si las había, las tortuosas madejas tejidas por el contagio: era posible que todo fuera un engendro de los demonios coléricos y sedientos de linfa animal, que pululan en el plano astral. $\mathrm{O}$ bien el efecto de la sangre mórbida de los orangutanes tornasolados, más pícaros y potentes que el hombre, cuyos coágulos, poco después de la caza y antes de los combates se impregnan en la piel los guerreros de ciertas tribus (925-926).

\footnotetext{
${ }^{126}$ Sontag analiza al sida como una enfermedad "del tiempo" en tanto es progresiva ya que "toda una plétora de síntomas incapacitantes, desfigurantes y humillantes hacen que el paciente de sida se vuelva cada vez más inválido, impotente e incapaz de controlar o cuidarse de las funciones y necesidades básicas" (2003: 107).
} 
Ignoramos, por lo tanto, toda posibilidad de clasificar, jerarquizar, rotular; en otras palabras, carecemos totalmente de los instrumentos del saber que permiten disciplinar y dominar, en este caso, esa enfermedad, el sida, que, aunque todos sabemos que de ella se trata, se nos escapa por los resquicios del discurso que no quiere $\longrightarrow$ o no puede - nombrarla. Tal vez, porque como apunta Elaine Showalter, comparándola con la sífilis como las dos enfermedades finiseculares — una del XIX y la otra del XX— : "both syphilis and AIDS have been interpreted as the inevitable outcome of the violation of "natural"sexual laws" (1991: 190); dicho de otro modo, como enfermedad simbólica, se ha convertido en parte de la historia y la identidad colectivas gay (191). Pero también, porque "como enfermedad considerada como sinónimo de muerte es cosa que hay que esconder" (Sontag 15).

Este desconocimiento fundamental da lugar a una gran desconfianza hacia la medicina tradicional traducida, no sólo a nivel discursivo a través de las apreciaciones de los personajes, sino también en la aparición, a nivel argumental, de una importante cantidad de prácticas terapéuticas alternativas — por ejemplo, las curas que Caimán y Caballo realizan con todo tipo de yerbas — que someten a los enfermos a "las intransigentes modas médicas" (943) y convierten a esta ciencia en un puro protocolo, formal y sin sentido alguno ${ }^{127}$.

\footnotetext{
${ }^{127}$ El uso de terapias alternativas a la medicina tradicional es un tópico que se repite desde Cobra en adelante y que tiene relevancia en cuanto constituye una crítica a cierto cientificismo y reúne varios significados posibles.

En primer lugar, -el más cercano a este trabajo- el que apela al discurso científico en tanto lenguaje disciplinado que tiene como función ordenar, disciplinar la enfermedad, el cuerpo y, por consiguiente, al sujeto. En segundo término, el que implica poner en funcionamiento una matriz cultural relacionada con las clases populares. En tercer lugar, y admito que éste puede ser el más discutible, el que establecería cierta relación entre esta crítica y la medicina como uno de los triunfos sobre los que se sustenta el discurso propagandístico del gobierno de la Revolución. Por último, no habría que olvidar el paso
} 
De este modo, perdido el anclaje científico-médico, la enfermedad se convierte en uno de los vértices de este triángulo indisoluble que forma con la escritura y el cuerpo, y que no tiene resolución posible sino en el reinicio persistente del ciclo de la vida y la muerte, del principio y el fin inscriptos ambos en un mismo y único acto: el de la escritura que desborda los límites de la explicación, que no designa ni ilustra, que no ilumina ni nombra. Por el contrario, es la escritura que narra, describe, confiesa, noveliza, elide. Es la escritura que literaturiza "en esta ausencia del tiempo y lugar, para que esa negación sea dicha y cada uno sienta en sí mismo esa inmóvil privación de ser" (964). 


\section{Conclusiones}

Desde Camagüey a La Habana y de allí a París. Desde Ciclón a Tel Quel; desde Gestos a Pájaros de la playa... Este trabajo no pretendió ser la reconstrucción de un recorrido por dos razones fundamentales: la primera, que ya no sería novedoso porque esa ruta se ha trazado y se ha trazado bien. La segunda, porque creo más en las brechas que en los itinerarios por lo que, ambiciosamente tal vez, procuré abrir resquicios que pudieran ser, a un mismo tiempo, causa y consecuencia de nuevas lecturas.

La intención del presente trabajo ha sido demostrar en qué medida cuerpo y escritura tejen una trama por la cual Sarduy construye su subjetividad de artista y escritor a partir de la que se posiciona como intelectual disidente con el modelo que impuso el campo cultural y político postrevolucionario cubano. Me ha interesado hacer evidente, entonces, que aunque Sarduy se ha mostrado reticente a manifestar posicionamientos comprometidos políticamente, en su obra asume una postura que en mi opinión es política en su más amplio sentido. Se presenta de este modo una paradoja que es importante señalar en tantota crítica, en general, no ha percibido esta particularidad de la obra sarduyana sino que la ha analizado, especialmente, en función del trabajo con el lenguaje. En este sentido, el título de este trabajo de investigación apunta a ser leído en un contexto crítico en que se advierta la "politicidad" de las categorías de lo subjetivo. Señalo entonces, algunos hitos, algunos mojones que sirven de marcas visibles e ineludibles para estas lecturas.

Severo Sarduy partió de un Camagüey provinciano hacia una Habana capitalina en efervescencia revolucionaria y cultural. Sus primeras 
intenciones fueron estudiar medicina pero la literatura y el arte lo ganaron definitivamente. Así, con una historia incipiente de participación en las publicaciones de su ciudad natal, comenzó a tener injerencia en los círculos intelectuales y artísticos de La Habana al punto no sólo de ser miembro activo en las publicaciones y eventos sino también de ganar una beca para cursar estudios de pintura en Francia.

Ya en París y en relación estrecha con uno de los grupos de intelectuales más preponderantes de mitad de siglo XX en adelante comenzó su obra novelística con Gestos en la que puso el germen de sus trabajos posteriores pero aún fuertemente anclado en la realidad social y política de la isla, en este caso, en los acontecimientos previos inmediatos al triunfo de la Revolución de 1959. Se conjugan entonces, ciertos rasgos del nouveau roman francés, algunos elementos del neobarroco latinoamericano y una temática histórico-política que se desliza entre las bambalinas de la tragedia griega y la charada cubana. Mujer, mulata, revolucionaria, artista y lavandera son las aristas de un sujeto contradictorio que se construye en las muchas márgenes culturales de una nación que, aunque se pretende mestiza, se levanta sobre la heterogeneidad problemática que ni siquiera el lenguaje puede suturar. Se abre, de este modo, un sendero en que el género textual y el género sexual irán dialogando en un entramado sobre el que operan las tres nociones que considero fundamentales en la obra sarduyana y que constituyen, por lo tanto, tres ejes vertebradores de mi trabajo: escritura, cuerpo y subjetividad.

En De donde son los cantantes, Cobra y Maitreya la producción sarduyana se encuentra fuertemente anclada en los postulados del 
postestructuralismo telqueliano y el neobarroco latinoamericano a partir de los cuales continúa el trazado de un linaje que, si en Gestos se sustentaba en la negación de los modelos épicos de la novela surgida después de la revolución cubana, aquí se presenta como reconocimientos y reevaluaciones de la obra de José Lezama Lima, por un lado, y en contraposición de las narrativas identitarias con afanes totalizadores como las de Alejo Carpentier o Cintio Vitier, por el otro. Así, se construye una genealogía cuyo problema en común ronda en torno a cuestiones como la cubanidad, la subjetividad pero cuya diferencia estriba en que lo que constituyen respuestas para otros, en Sarduy son preguntas que remiten a otras preguntas, mediante una interminable cadena metonímica en la que el objeto perdido, el objeto del deseo -el pequeño objeto $a-$ es, como tal, eternamente diferido, lingüísticamente inalcanzable. Goce y excesos marcan en estas obras la carencia constitutiva de un lenguaje que, como la $c(C)$ obra que se muerde la cola, sólo puede hablar de sí mismo, fetichizarse, erigirse en el centro de una escena descentrada de la que el Sujeto y la Literatura no son más que pálidos reflejos de una autoridad (autoritarismo) en deconstrucción. Artificialización extrema, neobarroco y postestructuralismo son las marcas registradas de una multiplicidad de procedimientos discursivos puestos en juego en estas novelas sarduyanas a los que se les suma la diversidad textual, la presencia inesperada de otros discursos sociales, la intertextualidad y el complejo tratamiento de las voces que reinscriben estos linajes en un contexto que pretende poner en discusión los mandatos sociales y culturales de la literatura "altisonante" mediante la incorporación desjerarquizada de otras expresiones artísticas. 
Por su parte, la cuestión del género sexual, que en Gestos venía anudada a una representación social fuertemente imbricada con la raza, adopta a partir de Cobra y Maitreya, connotaciones que la ligan más a una problemática corporal y sexual vinculadas ambas a ciertas políticas de exclusión implementadas durante los años "duros” de la Revolución cubana. Homoerotismo, travestimiento, abyección, exilio son los puntos clave de un trazado en el que vuelven a anudarse los tres ejes de este trabajo: cuerpo, subjetividad y escritura se ligan allí donde la censura y el "parametraje", la política y la historia han hecho del sujeto un "exiliado de sí mismo".

Cocuyo, Colibrí y Pájaros de la playa constituyen, por su parte, la simulación de un retorno. Con tramas narrativas más claras, más "respetuosas" de ciertas convenciones literarias las tres novelas parecen respetar formas convencionales según las que se encauzarían en parodia de la novela de la selva o construcción autobiográfica, sólo para aludir a las dos últimas. Sin embargo, la complejidad de la escritura sarduyana vuelve a impedirnos una clasificación genérica precisa porque nuevamente pone el sentido en los bordes, las fisuras y los límites, en este caso, no sólo del género - sexual, textual, gramatical— sino también del cuerpo, la enfermedad y la muerte.

Distan entre la publicación de la primera y la última de estas tres novelas menos de diez años que son los últimos de vida de Sarduy y es esta condición como de "muerte en acecho" la que parece estar presente a lo largo de su última obra narrativa. Si en Colibrí el sida es una presencia velada, hasta de alguna manera tangencial, no deja por eso de indicar el inicio de un proceso en que el cuerpo, el erotismo y la escritura se anudan, 
ahora, en torno a una problemática social, cultural, política, pero, sobre todo, existencial. Enlaces y desenlaces que tornó a contarnos — porque la Pelona se lo permitió- es una escritura que combina la fiesta y el dolor, la enfermedad y la literatura, el erotismo y los emplastes médicos.

Así, entre Cuba y Francia, neobarroco, postestructuralismo, cuerpo, sexualidad y muerte, Sarduy traza en sus obras un mapa plagado más de brechas que de caminos. Sinuoso, agrietado y difícil es un mapa que dibuja la construcción narrativa de una subjetividad política. 


\section{Bibliografía primaria}

Sarduy, Severo. (1999). Obra completa. Madrid: Sudamericana.

-------. Severo Sarduy en Cuba. 1953-1961. (Compilación, prólogo y notas de Cira Romero). Santiago de Cuba: Editorial Oriente, 2007.

-------. (1963). “Gestos”

-------. (1967). "De donde son los cantantes"

-------. (1967). "Dispersión. Falsas notas/ Homenaje a Lezama”

-------. (1972). "Cobra"

-------. (1972). "El barroco y el neobarroco"

-------. (1974). “El barroco"

-------. (1978). "Maitreya"

-------. (1982). “La simulación"

-------. (1984). “Colibrî”

--------. (1988). “El heredero"

-------. (1990). “Cocuyo”

--------. (1991). “Imágenes del tiempo inmóvil”

-------. (1991). "Pas de deux"

--------. (1991). “Diario de la peste”. Vuelta 206 (enero de 1994): 33-35.

-------. (1991). "El estampido de la vacuidad"

-------. (1993). "Pájaros de la playa” 


\section{Bibliografía secundaria}

Acosta, Leonardo. (1984). El Barroco de Indias y otros ensayos. La Habana: Casa de las Américas.

Adorno, Rolena. (1988). "Nuevas perspectivas en los estudios literarios coloniales hispanoamericanos". Revista de crítica literaria latinoamericana XIV, 28: 11-27.

Adrián, Francisco-Javier. (1994). "Para una arqueología de Pájaros de la playa". Paradiso $\mathrm{N}^{\mathrm{o}} 5$ (enero- febrero): 15-16.

Altuna, Elena. (2004). "Introducción: relaciones de viajes y viajeros coloniales por las Américas". Revista de Crítica Literaria Latinoamericana XXX, 60 (2do semestre): 9-23.

Amícola, José. (2008). “Camp”. En Amícola, José y José Luis de Diego (dir.). La teoría literaria hoy. Conceptos, enfoques, debates. La Plata: Ediciones Al Margen.

. (2006). "Hell Has No Limits: de José Donoso a Manuel Puig”. En Ingenschay, Dieter. Desde aceras opuestas. Literatura/ cultura gay y lesbiana en Latinoamérica. Vervuert: Iberoamericana.

-------. (2003). La batalla de los géneros. Novela gótica versus novela de educación. Rosario: Beatriz Viterbo Editora

(2000). Camp y posvanguardia. Manifestaciones culturales de un siglo fenecido. Buenos Aires: Paidós.

Angvic, Birger. (2006). "Arenas, Sarduy: sida y tanatografía". En Ingenschay, Dieter. Desde aceras opuestas. Literatura/ cultura gay y lesbiana en Latinoamérica. Vervuert: Iberoamericana.

Anz, Thomas. (2006) “Argumentos médicos e historias clínicas para la legitimación e institución de normas sociales". En Bongers, 
La construcción de la subjetividad en la narrativa de Severo Sarduy 254

Wolfgang y Tanja Olbrich (comps.). Literatura, cultura y enfermedad. Buenos Aires: Paidós.

Arfuch, Leonor (comp.). (2002). Identidades, sujetos y subjetividades. Buenos Aires: Prometeo libros.

Arcos, José Luis. (1999). "Orígenes: ecumenismo, polémica y trascendencia”. En Sosnowski, Saúl (ed.). La cultura de un siglo. América Latina en sus revistas. Buenos Aires: Alianza Editorial.

Arrufat, Antón. (1968). Los siete contra Tebas. La Habana, UNEAC.

Asensi Pérez, Manuel. (2006). Los años salvajes de la teoría. Phillipe Sollers, Tel Quel y la Génesis del pensamiento post-estructural francés. Valencia: tirant lo blanch.

Balderston, Daniel y Donna Guy. (1998). Sexo y sexualidades en América Latina. Buenos Aires: Paidós.

Barthes, Roland. (2002). El susurro del lenguaje. Más allá de la palabra y la escritura. Barcelona: Paidós Comunicación.

-------. (1977). El placer del texto y Lección inaugural. México: Siglo XXI, 1991.

--------. (1970). “Escribir la lectura”. En El susurro del lenguaje. Más allá de la palabra y la escritura. Barcelona: Paidós Comunicación.

------. (1970b). S/Z. Madrid: Siglo XXI, 2004.

-------. (1968). “La muerte del autor”. En El susurro del lenguaje. Más allá de la palabra y la escritura. Barcelona: Paidós Comunicación.

Basile, Teresa (2008). La vigilia cubana. Sobre Antonio José Ponte. Rosario: Beatriz Viterbo. 
Bejel, Emilio. (2001).Gay Cuban Nation. London: The University of Chicago Press.

Bernabé, Mónica. "Martí en la familia de Orígenes". En Bernabé, Mónica, Antonio José Ponte y Marcela Zanín. (2001) El abrigo de aire. Ensayos sobre literatura cubana. Rosario: Beatriz Viterbo.

Bethell, Leslie (ed.). (1998). Historia de América Latina. Barcelona: Grijalbo Mondadori.

Beverly, John. (1989). “Sobre Góngora y el gongorismo colonial”. Revista Hispanoamericana, 114-115, (enero-junio): 33-44.

Biagini, Graciela. (2009). Sociedad civil y VIH- Sida. ¿De la acción colectiva a la fragmentación de intereses? Buenos Aires: Paidós.

Billiet, Laura. (1995). H.I.V.-S.I.D.A. La época de inmunodeficiencia. Buenos Aires: Ediciones Nueva Visión.

Bongers, Wolfgang y Tanja Olbrich (comps.). (2006). Literatura, cultura y enfermedad. Buenos Aires: Paidós.

Braidotti, Rosi. (2000). Sujetos nómades. Buenos Aires: Paidós.

Buci- Glucksmann, Christine. (1993). "La manera o el nacimiento de la estética". En AAVV. Barroco y Neobarroco. Madrid: Círculo de Bellas Letras.

Burke, Seán. (1992). The Death and Return of the Author. Criticism and Subjectivity in Barthes, Foucault and Derrida. Edinburgh, Edinburgh University Press, 1998.

Bustillo, Carmen. (1996). Barroco y América Latina. Un itinerario inconcluso. Caracas: Monte Ávila. 
Bürger, Christa y Peter Bürger. (2001). La desaparición del sujeto. Una historia de la subjetividad de Montaigne a Blanchot. Madrid: ediciones Akal.

Bush, Andrew. (1984). "Huellas de la danza: gestos primeros del barroco sarduyano". En Carpentier, Alejo y Emir Rodríguez Monegal y otros. Historia y ficción en la narrativa hispanoamericana. Caracas: Monte Ávila editores.

Butler, Judith. (1993). Cuerpos que importan. Sobre los limites materiales y discursivos del "sexo". Buenos Aires: Paidós, 2002.

-------. (1990). El género en disputa. El feminismo y la subversión de la identidad. Barcelona: Paidós, 2007.

Calabrese, Omar. (1999). La era neobarroca. Madrid: Cátedra.

Carpentier, Alejo y Emir Rodríguez Monegal y otros. (1984). Historia y ficción en la narrativa hispanoamericana. Caracas: Monte Ávila editores.

Carpentier, Alejo. (1974). Concierto barroco. Buenos Aires: Nuestra América, 2005.

(1948). "Lo barroco y lo real maravilloso" en Tientos y diferencias Barcelona: Plaza \& Janés, 1987.

Castañeda, Marina. (2000). La experiencia homosexual. Para comprender la homosexualidad desde dentro y desde fuera. México: Paidós.

Casullo, Nicolás y otros. (1997). Itinerarios de la Modernidad. Corrientes del pensamiento y tradiciones intelectuales desde la Ilustración hasta la posmodernidad. Buenos Aires: Oficina de Publicaciones del $\mathrm{CBC}$ 
Catanzaro, Gisela. (2002). "Materia e identidad: el objeto perdido. Apuntes para una problematización materialista de la identidad”. En Arfuch, Leonor (comp.). Identidades, sujetos y subjetividades. Buenos Aires: Prometeo libros.

Celorio, Gonzalo. (2001). Ensayo de contraconquista. México: Tusquets Editores.

Colombi, Beatriz. (2006). "El viaje y su relato". Latinoamérica. Revista de Estudios Latinoamericanos, 043: 11-35.

(2004). Viaje intelectual. Migraciones y desplazamientos en América Latina (1880-1915). Rosario: Beatriz Viterbo Editora.

Cornejo Polar, Antonio. (1996). “Tradición migrante e intertextualidad multicultural: el caso de Arguedas". CELEHIS 6-8: 45-56.

-------. (1994). Escribir en el aire. Ensayo de la heterogeneidad sociocultural en las literaturas andinas. Lima: Editorial Horizonte.

Costa, Horacio. (1991). "Sarduy: la escritura como épure". Revista Iberoamericana 57, 154 (enero-marzo): 275-300.

Chiampi, Irlemar. (2000). Barroco y modernidad. México: Fondo de Cultura Económica.

De Diego, José Luis. (2001) ¿Quién de nosotros escribirá el Facundo? Intelectuales y escritores en Argentina (1970- 1986). La Plata: Ediciones Al Margen.

De Ferrari, Guillermina. (2002). "Enfermedad, cuerpo y utopía en Los pasos perdidos de Alejo Carpentier y en Pájaros de la playa de Severo Sarduy”. Hispanic Review 70, 2: 219-241. 
Deleuze, Gilles y Félix Guattari. (1975). Kafka. Por una literatura menor. México: Ediciones Era, 1998.

Derrida, Jacques. (1987). La deconstrucción en las fronteras de la filosofía. Barcelona: Paidós, 1997.

-------. (1969). La diseminación. Madrid: Fundamentos, 1997.

-------. (1968). “La différance”. En Redacción de Tel Quel. Teoría de conjunto. Barcelona: Seix Barral, 1971.

-------. (1967). De la gramatología. México: siglo XXI editores, 1998.

Descartes, René. (1637). El discurso del método. Meditaciones metafísicas. Buenos Aires: Gradifco, 2005.

Díaz, Duanel (2005). Los límites del origenismo. Madrid: Colibrí.

Domínguez, Jorge. (1998). “Cuba, 1959-c.1990”. En Bethell, Leslie (ed.). Historia de América Latina. Barcelona: Grijalbo Mondadori.

D’Ors, Eugenio. (1944). Lo barroco. Madrid: Aguilar, 1964.

Duno Gottberg, Luis. (2003). Solventando las diferencias. La ideología del mestizaje en Cuba. Madrid: Iberoamericana.

Elliott, Anthony. (1992). Teoría social y psicoanálisis en transición. Sujeto y sociedad de Freud a Kristeva. Buenos Aires: Amorrortu, 1995.

Epps, Brad. (2008). "Retos, riesgos, pautas y promesas de la teoría queer". Revista Iberoamericana LXXIV, 225 (oct- dic.): 897-920.

Evans, Dylan. (1997). Diccionario introductorio de psicoanálisis lacaniano. Buenos Aires: Paidós.

Feher, Michel. (1992). “Introducción”. En Feher, Michel, Ramona Naddal y otros. Fragmentos para una historia del cuerpo humano. Madrid: Taurus. 
Femenías, María Luisa. (2000). Entre sujeto y género. Lecturas feministas desde Beauvoir a Butler. Buenos Aires: Catálogos.

Fernández Retamar, Roberto. (1998). Todo Calibán. Chile: Cuadernos Atenea.

Fornet, Ambrosio. "El Quinquenio Gris: Revisitando el término". http://www.criterios.es/pdf/fornetquinqueniogris.pdf . Disponible el 20 de mayo de 2007: 1-22.

-------. (2001). "La diáspora cubana y sus contextos (Glosario)”. Casa de las Américas 222: 22-29.

--------. (1999). “Casa de las Américas: entre la revolución y la utopía”. En Sosnowski, Saúl (ed.). La cultura de un siglo. América Latina en sus revistas. Buenos Aires: Alianza.

Foster, David. (2008). "El estudio de los temas gay en América Latina desde 1980”. Revista Iberoamericana LXXIV, 225 (oct- dic.): 923-941.

Foucault, Michel. (1976). "La voluntad de saber" en Historia de la sexualidad. Tomo I. México: Siglo XXI editores, 2000.

-------. (1966). Las palabras y las cosas. Una arqueología de las ciencias humanas. México: siglo XXI editores, 1982.

(1963). "De lenguaje y literatura". En De lenguaje y literatura. Barcelona: Paidós, 1996.

Fowler, Alastair. (1988). "Género y canon literario”. En Garrido Gallardo, Miguel. Teoría de los géneros literarios. Madrid: Arcos Libros.

Fowler, Víctor. (1998). La maldición. Una historia de placer como conquista. La Habana: Editorial Letras Cubanas.

Freud, Sigmund. (1997). Obras completas. Buenos Aires: Amorrortu. 
-------. (1923). “El yo y el ello”.

-------. (1905). "El chiste y su relación con lo inconsciente".

-------. (1901). "Psicopatología de la vida cotidiana".

-------. (1900). “La interpretación de los sueños”.

Gamba, Susana (coord.) (2007). Diccionario de estudios de género y feminismos. Buenos Aires: Editorial Biblos.

Garrido Gallardo, Miguel. (1988). Teoría de los géneros literarios. Madrid: Arcos Libros.

Gay, Peter. (1992). “La obra de ficción”, "El precio de la represión”. En La experiencia burguesa. De Victoria a Freud. México: Fondo de Cultura Económica.

Gil, Lourdes y Fraida Itaurralde. (1991). "Visión cosmográfica en la obra de Severo Sarduy". Revista Iberoamericana LVII, 154: 337-341.

Gilman, Claudia. (2003). Entre la pluma y el fusil. Debates y dilemas del escritor revolucionario en América Latina. Buenos Aires: Siglo XXI Editores.

Goffman, Erving. (1963). Estigma. La identidad deteriorada. Buenos Aires: Amorrortu, 2006.

González Echevarría, Roberto. (1999). "Plumas, sí: de Donde son los cantantes y Cuba”. En Sarduy, Severo. Obra completa. Madrid: Sudamericana.

-------. (1997). “La nación desde De donde son los cantantes a Pájaros de la playa". Cuadernos Hispanoamericanos 563 (mayo): 55-67. (1987). La ruta de Severo Sarduy. Hanover: Ediciones del Norte.

-------. (1982). “El primer relato de Severo Sarduy”. Revista Iberoamericana 48, 118-119 (enero-junio): 73-90. 
(1975). "Memoria de apariencias y ensayo de Cobra". En Sarduy, Severo. Obra completa. Madrid: Sudamericana.

(1972). “Guapacho Barroco. Conversación con Severo Sarduy”. Papeles 16 (junio-julio): 25-47.

Goytisolo, Juan. (1986). En los reinos de taifa. Barcelona: Seix Barral.

Guerrero, Gustavo. (1980). La estrategia neobarroca. Estudio sobre el resurgimiento de la poética barroca en la obra narrativa de Severo Sarduy. Barcelona: EDICIONS DEL MALL.

Gundermann, Christian. (2003). "Perlongher el neobarroco y sus homosexualidades anti-neoliberales". Revista de Crítica Literaria Latinoamericana XXIX, 58 ( $2^{\circ}$ semestre): 131-156.

Gramuglio, María Teresa. “La construcción de la imagen” en Tizón, Héctor, Rodolfo Rabanal et. al. La escritura argentina. Universidad Nacional del Litoral, 1992.

Grijalva, Juan Carlos. (2004). "Vasconcelos o la búsqueda de la Atlántida. Exotismo, arqueología y utopía del mestizaje en La raza cósmica”. Revista de Crítica Literaria Latinoamericana XXX, 60 (2do. semestre): $333-349$.

Gruzinski, Serge. (2000). El pensamiento mestizo. Barcelona: Paidós.

Halperin Dongui, (1986). Tulio. Historia contemporánea de América Latina. Buenos Aires: Alianza Editorial.

Hatzfeld, Helmut. (1964). Estudios sobre el Barroco. Madrid: Gredos.

Hauser, Arnold. (1953). Historia social de la literatura y el arte. Desde la prehistoria hasta el Barroco. Tomo 1. Buenos Aires: Debate, 2006. 
Hobsbawm, Eric. (1994). Historia del siglo XX. Buenos Aires: Crítica, 1998.

Hörisch, Jochen. (2006). "Las épocas y sus enfermedades. El saber patognóstico de la literatura". En Bongers, Wolfgang y Tanja Olbrich (comps.). Literatura, cultura y enfermedad. Buenos Aires: Paidós.

Ingenschay, Dieter. (2006). Desde aceras opuestas. Literatura/ cultura gay y lesbiana en Latinoamérica. Vervuert: Iberoamericana.

Irwin, Alexander, Joyce Millen y otros. (2005). SIDA GLOBAL: verdades y mentiras. Herramientas para luchar contra la pandemia del siglo XXI. Buenos Aires: Paidós.

Jameson, Fredric. (1995). Imaginario y simbólico en Lacan. Buenos Aires: El cielo por asalto ediciones, (1997). Periodizar los 60. Córdoba: Alción Editora.

Jitrik, Noé (comp.) (2008). El despliegue. De pasados y futuros en la literatura latinoamericana. Buenos Aires: NJ Editor.

Kaminsky, Amy. (2008). "Hacia un verbo queer". Revista Iberoamericana LXXIV, 225 (oct- dic.): 879-895.

Kanzepolsky, Adriana (2004). Un dibujo del mundo: extranjeros en Orígenes. Rosario: Beatriz Viterbo.

Kristeva, Julia. (1988). Étrangers à nous-mêmes. Francia: Gallimard.

-------. (1980). Poderes de la perversión. México: Siglo XXI editores, 2006.

(1977). "El sujeto en proceso". En Sollers, Philippe (dir.). Artaud. Valencia: Pretextos. 
-------. (1977). “Un Noveau Type D’Intellectuel: Le Dissident”. Tel Quel, 74: 3-8.

--------. (1969). Semiótica 1. Madrid: Editorial Fundamentos, 1981.

-------. (1969). Semiótica 2. Madrid: Editorial Fundamentos, 1981.

Kushigian, Julia. (1999). "Severo Sarduy, orientalista posmodernista en camino hacia la autorrealización. Une ménagerie a trois: Cobra, Colibrí y Cocuyo". En Sarduy, Severo. Obra completa. Madrid: Sudamericana.

Kutzinski, Vera M. (1993). Sugar's secrest. Race and the Erotics of Cuban Nationalism. Virginia: New World Studies, James Arnold Series Editor.

Lacan, Jacques. (1974). El seminario de Jacques Lacan: libro XX: Aún. Buenos Aires: Paidós, 2006. (1966). Escritos 1. Buenos Aires: Siglo XXI editores, 2007.

------. (1966). Escritos 2. Buenos Aires: Siglo XXI editores, 2005.

Lancaster, Roger. (1998). “La actuación de Guto. Notas sobre el travestismo en la vida cotidiana”. En Balderston, Daniel y Donna Guy. Sexo y sexualidades en América Latina. Buenos Aires: Paidós.

Laplanche, Jean y Jean- Bertrand Pontalis. (1967). Diccionario de Psicoanálisis. Buenos Aires: Paidós, 1999.

Laqueur, Thomas. (1994). La construcción del sexo. Cuerpo y género desde los griegos hasta Freud. Madrid: Cátedra.

Larsen, Neil. (1993). "En contra de la des-estetización del "discurso" colonial”. Revista de Crítica Literaria Latinoamericana XIX, 37, (1º semestre): $335-342$. 
Le Breton, David. (2002). Antropología del cuerpo y modernidad. Buenos Aires: Nueva Visión.

-------. (2002). La sociología del cuerpo. Buenos Aires: Nueva Visión.

Leclerq, Cécile. (2004). El lagarto en busca de una identidad. Cuba: identidad nacional y mestizaje. Madrid: Iberoamericana.

Leiner, Marvin. (1994). Sexual Politics in Cuba. Machismo, Homosexuality and AIDS. Boulder, San Francisco and Oxford: Westview Press.

Levine, Suzanne. (1991). "Escritura, traducción, desplazamiento (un acercamiento a Maitreya)". Revista Iberoamericana 57, 154, (eneromarzo): 309-315.

Lezama Lima, José. (1957). La expresión americana. México: Fondo de Cultura Económica, 2005.

Lie, Nadia. (1996). Transición y Transacción. La revista cubana Casa de las Américas. (1960-1976). Bélgica: Hispamérica/ Leven Up.

Lumsden, Ian. (1996). Machos, Maricones and Gays. Cuba and Homosexuality. Philadelphia: Temple University Press.

Llamas, Ricardo. (1998). Teoría torcida. Prejuicios y discursos en torno a la "homosexualidad”. Madrid: Siglo XXI de España editores. y Javier Vidarte. (1999). Homografías. Madrid: Espasa Calpe.

López Lemus, Virgilio. (1997). La imagen y el cuerpo: Lezama y Sarduy. La Habana: Ediciones UNION.

Machover, Jacobo. (2001). La memoria frente al poder. Escritores cubanos del exilio: Guillermo Cabrera Infante, Severo Sarduy, Reinaldo Arenas. Zaragoza: Universitat de València. 
Mandolessi, Silvana. (2009). La abyección como categoría analítica en la obra de Witold Gombrowicz. Tesis Doctoral. Lovaina.

Mannoni, Octave. (1997). La otra escena. Claves de lo imaginario. Buenos Aires: Amorrortu.

Manzoni, Celina (2001). Un dilema cubano. Nacionalismo y vanguardia. La Habana: Casa de las Américas.

Maravall, José Antonio. (1975). La cultura del Barroco. Barcelona: Ariel, 1981.

Márquez, Enrique. (1988). "Cobra: de aquel oscuro objeto del deseo". Revista Iberoamericana. LVII, 28: 229-251.

Mariaca Iturri, Guillermo. (1993). El poder de la palabra. La Habana: Casa de las Américas.

Martín- Barbero, Jesús. (2003). De los medios a las mediaciones. Bogotá: Convenio Andrés Bello, 2003.

Melo, Adrián. (2005). El amor de los muchachos. homosexualidad y literatura. Buenos Aires: Ediciones Lea.

Méndez, Adriana. (1978). "Erotismo, cultura y sujeto en De Donde Son los Cantantes". Revista Iberoamericana XLIV, 102-103: 45-63.

Menton, Seymour. (1984). "Modelos épicos para la novela de la Revolución Cubana”. En Carpentier, Alejo y Emir Rodríguez Monegal y otros. Historia y ficción en la narrativa hispanomericana. Caracas: Monte Ávila editores.

Minelli, María Alejandra. (2006). Con el aura del margen (cultura argentina en los '80/ '90). Córdoba: Alción. 
Mondimore, Francis Mark. (1998). Una historia natural de la homosexualidad. Barcelona: Paidós.

Montaldo, Graciela. (1995). "El cuerpo de la patria: espacio, naturaleza y cultura en Bello y Sarmiento". En Beatriz González Stephan, Javier Lasarte, Graciela Montaldo y María Julia Daroqui (comps.). Esplendores y miserias del siglo XIX. Cultura y sociedad en América Latina. Caracas: Monte Avila Editores y Equinocio Ediciones de la Universidad Simón Bolivar.

Moraña, Mabel. Viaje al silencio. Exploraciones del discurso barroco. www.cervantesvirtual.com. Disponible el 01/05/07.

Mudrovcic, María Eugenia. (1999). “América Latina desde París (A propósito de Libre). En Sosnowski, Saúl (ed.). La cultura de un siglo. América Latina en sus revistas. Buenos Aires: Alianza.

Naranjo, Rodrigo. (2004). "Barroco latinoamericano y formación de la razón burocrática contemporánea”. Revista de Crítica Literaria Latinoamericana XXX, 60: 295-310.

Navarro, Desiderio. (1997). “Intertextualité: treinta años después". Intertextualité. Francia en el origen de un término y el desarrollo de un concepto. La Habana, Casa de las Américas-UNEAC-Embajada de Francia.

Ortega, José. (1994). "La imaginación neobarroca de Severo Sarduy en Pájaros de la playa”. Monographic Review/ Revista Monográfica. $\mathrm{X}: 110-119$.

(1984). La estética neobarroca en la narrativa hispanoamericana.

Madrid: Porrúa Turanzas. 
Ortega, Julio. (1973). Relato de la utopía. Barcelona: La Gaya Ciencia.

Ortiz, Fernando. (1987). Contrapunteo cubano del tabaco y del azúcar. Caracas: Biblioteca Ayacucho.

Paéz, D. y otros. (1991). SIDA: imagen y prevención. Madrid: Editorial Fundamentos.

Pellón, Gustavo. (1988). "Juan Goytisolo y Severo Sarduy: Discurso e Ideología”. Hispanic Review 56, 4: 483-492.

-------. (1983). “Severo Sarduy's strategy of irony: paradigmatic indecision in Cobra and Maitreya". Latin American Literary Review, XI, 23, (otoño-invierno): 7-13.

Pizarro, Ana. (2004). El sur y los trópicos. Ensayos de cultura latinoamericana. Murcia: Cuadernos de América sin nombre.

--------. (1985). La literatura latinoamericana como proceso. Buenos Aires: CEAL.

Ponte, Antonio José (2002). El libro perdido de los origenistas. México: Aldus.

Porter, Roy. (1993). "Historia del cuerpo". En Burke, Peter ed. Formas de hacer historia. Madrid: Alianza.

Pratt, Mary Louise. (1997). Ojos imperiales. Literatura de viajes y transculturación. Bernal: Universidad Nacional de Quilmes.

Prieto, René. (1991). "La persistencia del deseo: Colibrí de Severo Sarduy". Revista Iberoamericana 57, 154 (enero-marzo): 317-326.

Quintero Herencia, Juan Carlos. (2002). Fulguración del espacio. Letras e imaginario institucional de la Revolución Cubana (1960-1971). Rosario: Beatriz Viterbo. 
Quiroga, José. (1998). "Homosexualidades en el trópico de la revolución” en Balderston, Daniel y Donna Guy. Sexo y sexualidades en América Latina. Buenos Aires: Paidós.

Rama, Ángel. (1982). Transculturación narrativa en América Latina. Buenos Aires: Ediciones El Andariego, 2007.

Rincón, Carlos. (1996). Mapas y pliegues. Ensayos de cartografía cultural y de lectura del Neobarroco. Colombia: Colcultura.

Rivero Potter, Alicia. (1983). “Algunas metáforas somáticas —eróticoescripturales- en De donde son los cantantes y Cobra". Revista Iberoamericana 49, 123-124 (abril-sept.): 497-507.

Rodríguez Coronel, Rogelio. (1993). "De donde es Severo Sarduy". Casa de las América XXXIV, 192: 116-119.

Rodríguez de la Flor, Fernando. (2002). Barroco. Representación e ideología en el mundo hispánico (1580-1680). Madrid: Cátedra.

Rodríguez Monegal, Emir. (1982). "Literatura y exilio”. Vuelta. 6, 63 45-47. Roggiano, Alberto. (1978). “Acerca de dos barrocos: el de España y el de América”. Actas del XVII Congreso de Instituto Internacional de Literatura Iberoamericana. Madrid: Ediciones Cultura Hispánica del Centro Iberoamericano de Cooperación.

Rojas, Rafael. (2005). "El campo roturado. Políticas intelectuales de la narrativa cubana". Katatay I, 1 (junio): 42-51.

Rollin, Bernard. (1988). "Naturaleza, convención y teoría del género". En Garrido Gallardo, Miguel. Teoría de los géneros literarios. Madrid: Arcos Libros. 
Rueda, María Helena. (2003). "La selva en las novelas de la selva". Revista de Crítica Literaria Latinoamericana XXIX, 57 (1er semestre): 3143.

Said, Edward. (1996). Representaciones del intelectual. Barcelona: Paidós.

Sancholuz, Carolina, Roxana Páez y Néstor Ponce. (1998). "De la estética neobarroca al plato de ajiaco: una lectura sobre De donde son los cantantes de Severo Sarduy". Cuadernos Angers- La Plata. La PlataAngers: Université d' Angers-Universidad Nacional de La Plata, 2: $65-77$.

Santos, Lidia. (2001).Kitsch Tropical. Los medios en la literatura y el arte en América Latina. Madrid: Iberoamericana.

Schaeffer, Jean-Marie. (1988). "Del texto al género. Notas sobre la problemática genérica". En Garrido Gallardo, Miguel. Teoría de los géneros literarios. Madrid: Arcos Libros.

Schulman, Iván. (1966). “La situación y Gestos: dos técnicas y dos visiones de la realidad cubana". Duquesne Hispanic Review. Revista Hispánica de la Universidad de Duquesne V, 3: 121-133.

Showalter, Elaine. (1991). "The Woman's Case", “The Way We Write Now: Syphilis and AIDS”. En Sexual Anarchy. Gender and Culture at the Fin de Siècle. New York: Penguin.

Silva, María Guadalupe. (2008). "Severo Sarduy, un heredero en el exilio". En Jitrik, Noé (comp.). El despliegue. De pasados y futuros en la literatura latinoamericana. Buenos Aires: NJ Editor.

Sollers, Philippe (dir.). (1977). Artaud. Valencia: Pretextos. 
Sontag, Susan. (1977). La enfermedad y sus metáforas. Buenos Aires: Alfaguara, 2003.

------. (1988). El sida y sus metáforas. Buenos Aires: Alfaguara, 2003.

------. (1964). “Notas sobre lo camp”. En Contra la interpretación. Buenos Aires: Alfaguara, 2005.

Sosnowski, Saúl (ed.). La cultura de un siglo. América Latina en sus revistas. Buenos Aires: Alianza, 1999.

Tapié, Víctor- Lucien. (1961). El barroco. Buenos Aires: EUDEBA, 1981.

Ulloa, Leonor A. de. (1989). "Signos en rotación en el neobarroco pictórico de Severo Sarduy”. Hispamérica XVIII, 52: 97-108.

Ulloa, Leonor A. de y Justo Ulloa. (1999). "La obsesión del cuerpo en la obra de Severo Sarduy”. En Sarduy, Severo. Obra completa. Madrid: Sudamericana.

--------. (1994). “La función del fragmento en Colibrî”. MLN 109, 2: 268282.

-------. (1984). “Señales enviadas desde Arecibo: conversación con Severo Sarduy”. Crítica Hispánica 6, 2: 175-180.

-------. (1975). “Leyendo las huellas de Auxilio y Socorro”. Hispamérica $10:: 9-24$

. (1975). "Proyecciones y Ramificaciones del Deseo en "Junto al Río de Cenizas de Rosa"”. Revista Iberoamericana XLI, 92-92: 569-578. 
Vasconcelos, José. La raza cósmica. Misión de la raza iberoamericana. http://www.ensayistas.org/antologia/XXA/vasconcelos/ (Disponible el 24/01/2006).

Vázquez Ayora, Gerardo. (1984). "Estudio estilístico de Cobra". Revista Hispamérica: $35-42$.

Welton, Donn. Body and Flesh. A Philosophical Reader. Malden, Massachsetts: Blackwell Publishers, 1998.

Zanetti, Susana. (1994). "Religación. Un modo de pensar la literatura latinoamericana". El Dorado I, 1: 5-8.

Zurbano Torres, Roberto. (2001). "Etnos, literatura y nación: el triángulo invisible del siglo XX cubano”. Ponencia leída en Latin American Assocation: 1-20. 